UNIVERSIDADE DE SÃO PAULO

FACULDADE DE FILOSOFIA, LETRAS E CIÊNCIAS HUMANAS

DEPARTAMENTO DE LETRAS MODERNAS

PROGRAMA DE PÓS-GRADUAÇÃO LÍNGUA E LITERATURA ITALIANA

ADRIANA DE OLIVEIRA PITARELLO

A ópera lírica como instrumento de ensino do italiano LE: teorias e práticas

São Paulo

2009 


\section{ADRIANA DE OLIVEIRA PITARELLO}

A ópera lírica como instrumento de ensino do italiano LE: teorias e práticas

Dissertação a ser apresentada ao Programa de PósGraduação em Língua e Literatura Italiana do Departamento de Letras Modernas, da Faculdade de Filosofia, Letras e Ciências Humanas da Universidade de São Paulo, para a obtenção do título de Mestre em Letras.

Orientador: Profa. Dra. Paola Giustina Baccin.

Versão Corrigida

São Paulo 
AUTORIZO A REPRODUÇÃO E DIVULGAÇÃO TOTAL OU PARCIAL DESTE TRABALHO, POR MEIO CONVENCIONAL OU ELETRÔNICO, PARA FINS DE ESTUDO E PESQUISA, DESDE QUE CITADA A FONTE.

Pitarello, Adriana de Oliveira

A ópera lírica como instrumento de ensino do italiano LE: teorias e práticas / Adriana de Oliveira Pitarello ; orientadora Paola Giustina Baccin. -- São Paulo, 2009.

$185 \mathrm{f}$. + anexos

Dissertação (Mestrado - Programa de Pós-Graduação em Língua e Literatura Italiana) - Faculdade de Filosofia, Letras e Ciências Humanas da Universidade de São Paulo.

1. Ensino de língua estrangeira. 2. Língua italiana - teoria e ensino. 3. Ópera - estudo e ensino. I. Título. II. Baccin, Paola Giustina. 


\section{FOLHA DE APROVAÇÃO}

Adriana de Oliveira Pitarello

A ópera lírica como instrumento de ensino do italiano LE: teorias e práticas

Dissertação de mestrado, pelo Departamento de Letras Modernas, Área de Língua e Literatura Italiana, da Universidade de São Paulo, sob orientação da Profa. Dra. Paola Giustina Baccin.

Aprovada em:

Banca Examinadora

$\operatorname{Prof}(\mathrm{a}) \cdot \operatorname{Dr}(\mathrm{a}) .:$

Instituição:

Assinatura:

Prof(a). Dr(a):

Instituição:

Assinatura: 
Aos meus pais e à Irene Lucchini, que tornaram o meu sonho possível.

Ao meu filho, Matheus, que tornou o meu sonho completo. A todos que me inspiram a continuar sonhando... 


\section{AGRADECIMENTOS}

À Paola, mentora que, além de ter me ensinado tanto, tirou-me das atribulações graças a dicas e idéias preciosas. Obrigada por acreditar em mim!

Aos Profs. Elisabetta Santoro, Paolo Balboni, Sergio Casoy, Luiz Augusto Tatit, Emerson de Pietri, Loredana Stauber de Caprara, Neide González e Aleksandar Jovanovic pelas valiosas aulas, conselhos e orientação paralela.

À CAPES, fundação que contemplou minha pesquisa com seu financiamento, e aos professores da área de Língua e Literatura Italiana, que possibilitaram minha capacitação.

Aos funcionários do Departamento de Letras Modernas da FFLCH, sempre muito atenciosos e prestativos - sobretudo a Edite Mendez Pi, muito competente no seu trabalho.

Aos colegas de pós (sobretudo Vanessa Cristina Lourenço (in memoriam), Alexandre Antoniazzi, Roseli Dornelles dos Santos, Luciana Rita Mauro, Marta Pérez Rodriguez, Ana Aparecida Teixeira da Cruz e Glaucia Roberta Rocha Fernandes), que foram pacientes para discutir idéias e dar sugestões sempre que possível.

Aos meus alunos do curso "Rigoletto: per gli amanti della lingua e della cultura italiana", que me certificaram da relevância deste estudo.

A todos os meus queridos alunos (sobretudo Paschoal Milani Neto e Daniel Ferreira), que acompanham de perto minha carreira acadêmica e torcem por meu sucesso profissional.

Aos meus queridos familiares e amigos, em especial Terezinha de Fátima Pitarello, Tasso Augusto Campana dos Santos, Maria Aparecida de Oliveira Silva e Edmilson Brito Rodrigues, com os quais sei que posso contar sempre. 
"A Cinguagem musical é um tipo muito diferente da linguagem significante. Nisto reside seu aspecto refigioso. O que é dito, no fenômeno musical, é ao mesmo tempo preciso e escondido. Toda música tem por Idéia a forma de um Nome divino. Prece desmistificada, libertada da magia do efeito, a música representa a tentativa humana, por mais vã que possa ser, de enunciar o próprio $\mathcal{N}$ ome, ao invés de comunicar as significações."

Theodoro W. Adorno

"Não existe meio mais seguro para fugir do mundo do que a arte, e não há forma mais segura de se unir a ele do que a arte."

Johann Goethe

"Feliz aquele que transfere o que sabe e aprende o que ensina."

Cora Coralina 


\section{RESUMO}

PITARELLO, A. 215 p. A ópera lírica como instrumento de ensino do italiano LE: teorias e práticas. 2009. Dissertação (Mestrado) - Faculdade de Filosofia, Letras e Ciências Humanas, Universidade de São Paulo, São Paulo, 2009

A ópera lírica pode constituir um excelente material didático a ser trabalhado em todos os níveis da educação linguística, não apenas devido ao seu irrefutável valor cultural, histórico e social, mas, principalmente, por sincretizar as linguagens musical, teatral e literária, transformando-se, assim, em um fecundo instrumento de ensino da língua italiana. A partir dos preceitos semióticos de análise, sobretudo no que concerne aos estudos sobre a Semiótica das Paixões, a ópera lírica pode ser didatizada e apresentada aos alunos no seu formato autêntico, visando à formação e autonomia discente. De fato, o percurso adotado pretende simular o percurso de geração de sentidos, partindo dos afetos da música para chegar às ações do enredo. A parte prática deste trabalho é dedicada ao curso "Rigoletto: per gli amanti della lingua e della cultura italiana", elaborado especialmente para legitimar a proposta de se trabalhar a ópera lírica nas aulas de italiano LE. Trata-se de uma unidade didática sobre Rigoletto, uma importante produção de Giuseppe Verdi e Francesco Maria Piave, de 1851. Em síntese, neste trabalho, pretendo discorrer sobre as teorias que envolvem a didatização da ópera lírica e ilustrar a sua aplicação a partir das atividades do referido curso. Finalmente, os resultados obtidos durante a fase de avaliação serão utilizados para comprovar a sua eficácia.

Palavras-chave: ensino da língua italiana, ópera lírica, material autêntico, Semiótica das Paixões, Rigoletto 


\begin{abstract}
PITARELLO, A. 2009. 215 p. The lyrical opera as a teaching material for italian foreing language: theories and practices. Dissertation (Master's Degree) - Faculdade de Filosofia, Letras e Ciências Humanas, Universidade de São Paulo, São Paulo, 2009

Lyrical opera can be an excellent teaching material for use at all levels of language education, not only because of its unquestionable cultural, historical and social value, but mainly for amalgamating musical, theatrical and literary languages, thereby forming a productive tool for teaching the Italian language. Based on the precepts of semiotic analysis, especially with regard to studies of the Semiotics of Passions, lyrical opera can be taught and presented to students in its authentic format, aimed at student training and autonomy. Indeed, the route adopted simulates the passage through the three levels of textual analysis, starting from the musical moods to arrive at the actions of the plot. The practical part of this work is dedicated to the course "Rigoletto: per gli amanti della lingua e della cultura italiana", especially designed to legitimize the proposal to employ lyrical opera in Italian lessons for foreign learners. This is a teaching unit about Rigoletto, an important work by Giuseppe Verdi and Francesco Maria Piave, 1851. In summary, in this work I intend to discuss theories involving the teaching use of lyrical opera and illustrate its application based on the activities of that course. Finally, the results obtained during the assessment phase will be used to prove its effectiveness.
\end{abstract}

Key words: Italian language teaching, lyrical opera, authentic material, Semiotics of Passions, Rigoletto 


\section{RIASSUNTO}

PITARELLO, A. L'opera lirica come strumento dell'insegnamento dell'italiano LS: teorie e pratiche. 2009. 215 p. Tesi (Master) - Faculdade de Filosofia, Letras e Ciências Humanas, Universidade de São Paulo, São Paulo, 2009

L'opera lirica può costituire un eccellente materiale didatico con cui lavorare in tutti i livelli dell'educazione linguistica, non solo per il suo innegabile valore culturale, storico e sociale, ma soprattutto perché concilia i linguaggi musicale, teatrale e letterario, trasformandosi in un fecondo strumento di insegnamento della lingua italiana. A partire dai precetti semiotici di analisi, soprattutto per quanto riguarda la Semiotica delle Passioni, l'opera lirica può essere didattizzata e presentata agli alunni nel suo formato autentico, per cui viene finalizzata alla formazione e autonomia discente. Infatti, il percorso adottato vuole simulare il percorso generativo del senso partendo dagli affetti della musica verso le azioni dell'intreccio. La parte pratica di questo lavoro è poi dedicata al corso "Rigoletto: per gli amanti della lingua e della cultura italiana", che è stato specialmente elaborato per legittimare la proposta di utilizzare l'opera lirica come strumento nelle lezioni di italiano LS. Si tratta di un'unità didattica su un'importante produzione di Giuseppe Verdi e Francesco Maria Piave, Rigoletto appunto, esordita nel 1851. In questo lavoro, insomma, intendo discorrere delle teorie che interessano la didattizzazione dell'opera lirica nonché illustrare la sua applicazione a decorrere dalle attività del suddetto corso. Finalmente, i risultati ottenuti durante la fase di valutazione verranno utilizzati per comprovare la sua efficacia.

Parole-chiave: insegnamento della lingua italiana, opera lirica, materiale autentico, Semiotica delle Passioni, Rigoletto 


\section{SUMÁRIO}

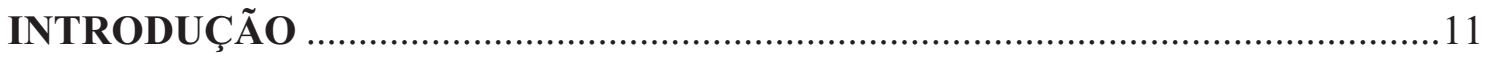

1 LÍNGUA E CULTURA NAS AULAS DE LÍNGUA ESTRANGEIRA …............16

1.1 A CULTURA NO CURRÍCULO DE LÍNGUA ESTRANGEIRA ......................20

1.2 A ÓPERA NA EDUCAÇÃO E NO ENSINO ......................................................22

1.3 A ÓPERA NAS AULAS DE LÍNGUA ESTRANGEIRA ..................................25

2 O GÊNERO ‘ÓPERA’ E SUAS IMPLICAÇÕES DIDÁTICAS .........................26

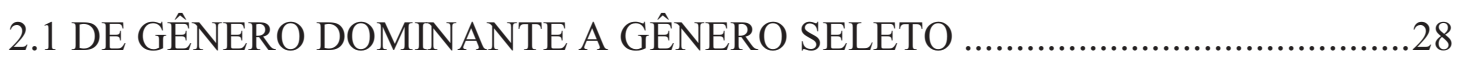

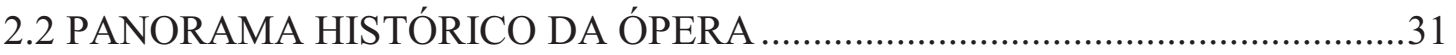

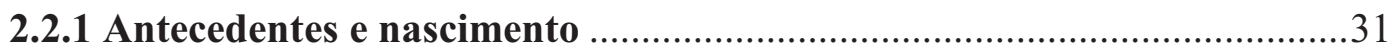

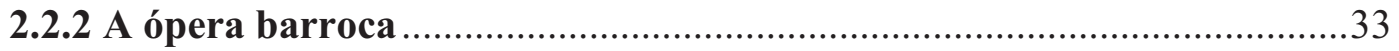

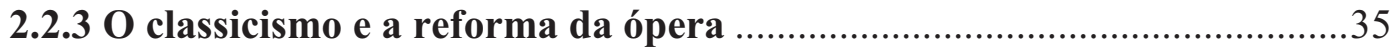

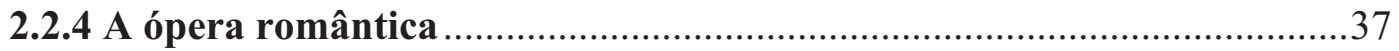

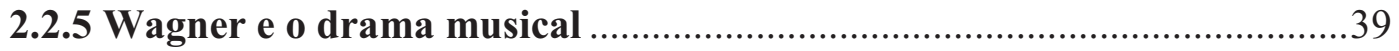

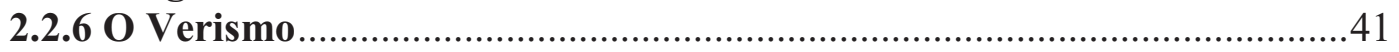

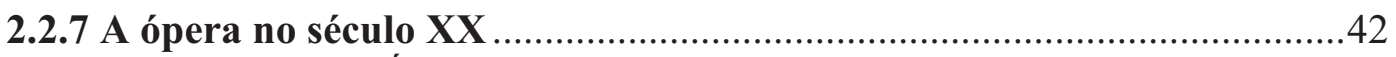

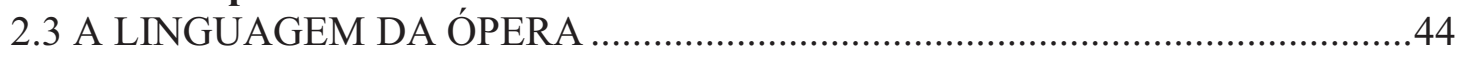

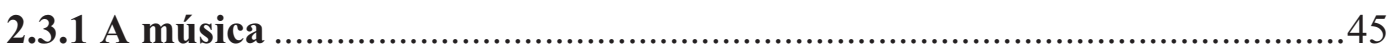

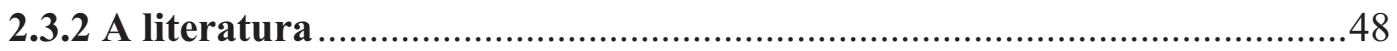

2.3.2.1 Léxico, Figuras de Linguagem e Morfossintaxe .............................50

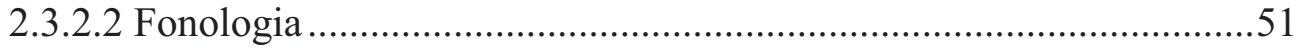

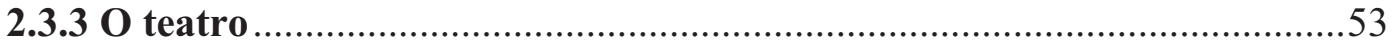

\section{A APRESENTAÇÃO DA ÓPERA NAS AULAS}

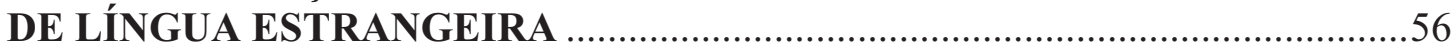

3.1 A ÓPERA COMO MATERIAL AUTÊNTICO....................................................56

3.2 A COLABORAÇÃO ENTRE AS DIVERSAS LINGUAGENS DA ÓPERA.......58

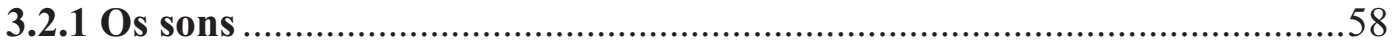

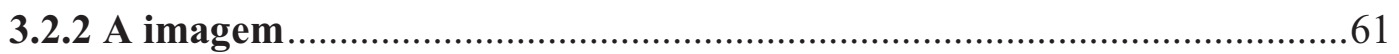

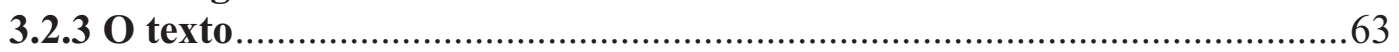

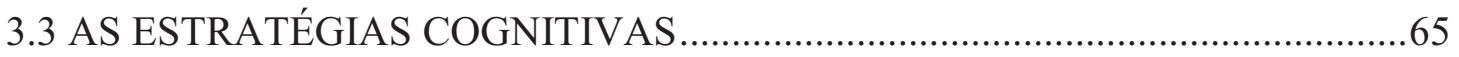

3.3.1 Primeira fase: A "leitura" dos sons e das imagens ................................65

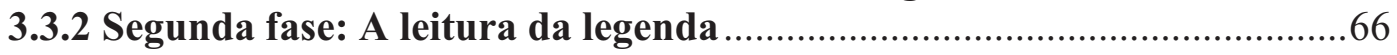

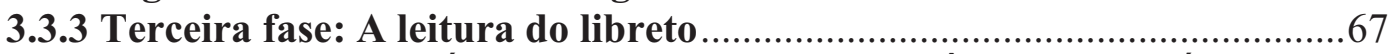

3.4 PRERROGATIVAS DIDÁTICAS PARA O USO AUTÊNTICO DA ÓPERA ...70

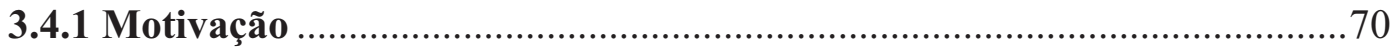

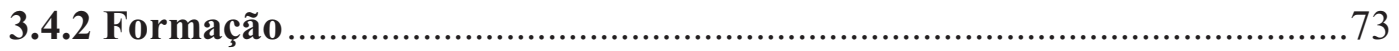

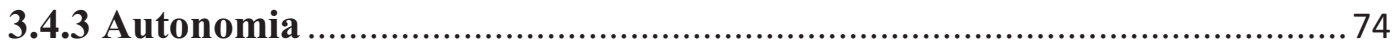

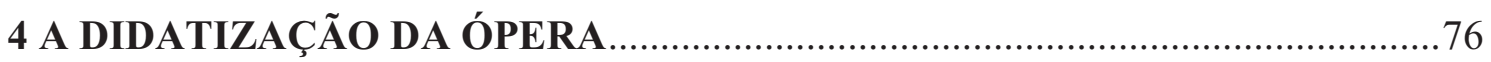

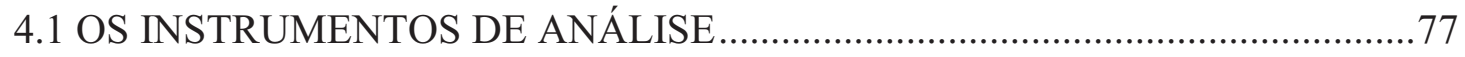

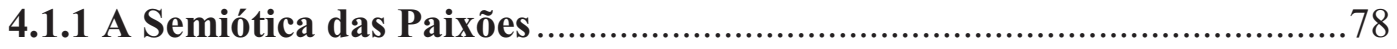




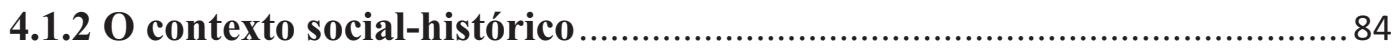

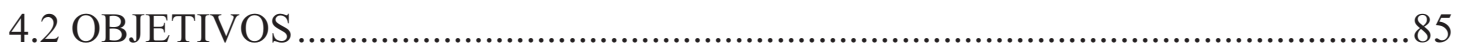

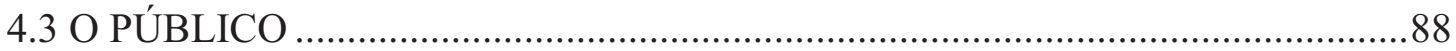

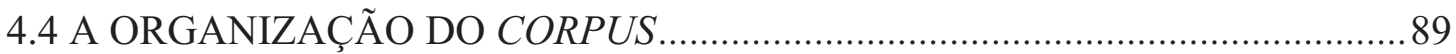

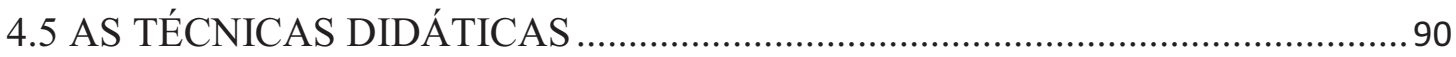

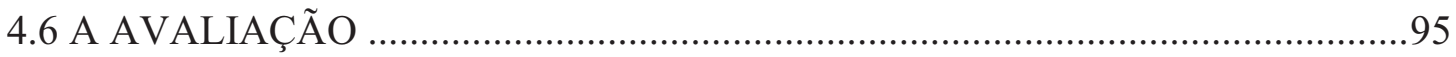

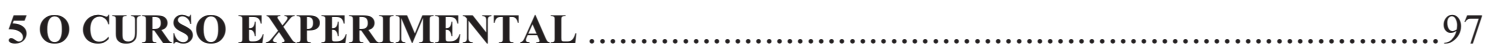

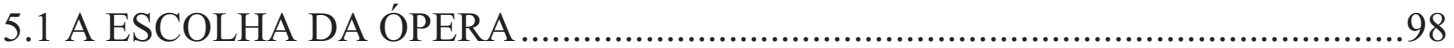

5.2 ANÁLISE DE RIGOLETTO, DE GIUSEPPE VERDI ....................................... 100

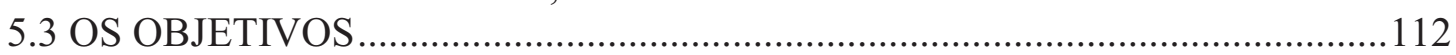

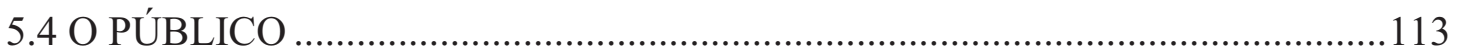

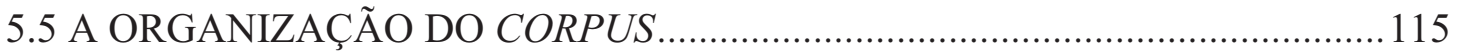

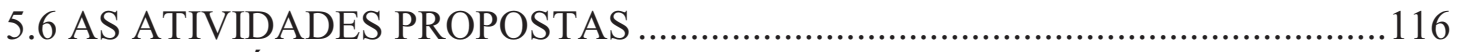

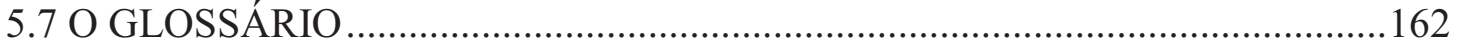

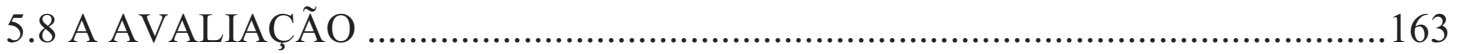

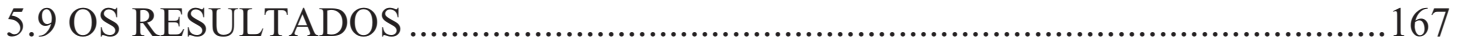

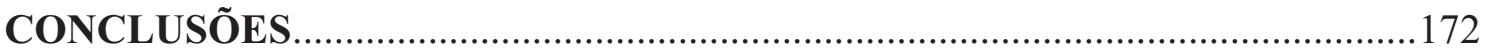

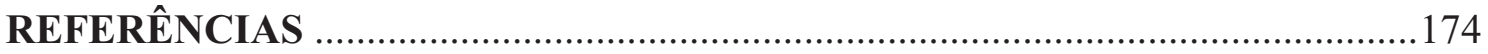

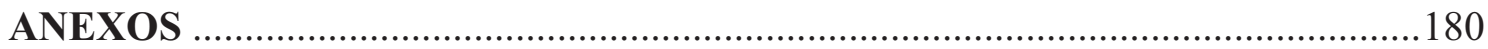




\section{INTRODUÇÃO}

"Non si insegna solo una lingua ma anche la cultura che vi sta dietro."

Paolo Balboni

A ideia de se trabalhar a ópera lírica em classe surgiu da necessidade de atender às expectativas de alguns alunos amantes do gênero já no início da minha experiência como professora de língua italiana. Alguns pediam para ouvir, em lugar das "clássicas" canções de Laura Pausini e Eros Ramazzotti, tão empregadas nas aulas de italiano, algo mais clássico no sentido estrito do termo, como uma ária de Verdi ou de Bizet, por exemplo. Infelizmente, eu, como a grande maioria dos professores, não tinha nenhuma familiaridade com a ópera, e considerava a sua linguagem pouco compreensível e muito diferente dos materiais com os quais estava acostumada a trabalhar. Por isso, como um desafio, decidi satisfazer os anseios do meu público mais culto, e passei a levar, ainda que esporadicamente, árias famosas como "Nessun dorma" ou "La donna è mobile" às aulas.

Entretanto, o trabalho em classe com esses textos praticamente não se diferenciava, em termos didáticos, do trabalho realizado com as canções de outros gêneros. Utilizava as habituais técnicas de completamento, de inversão dos versos e outras tantas que trabalham apenas a compreensão oral do aluno, sem enxergar, ainda, o mar de possibilidades que um gênero tão completo como a ópera poderia oferecer ao estudo da língua italiana.

Mesmo assim, a sensação de que se poderia ir muito além cresceu ao longo do tempo, e tornou-se incessante após a decisão de dissertar sobre o tema no mestrado. Lembro-me de que, durante a entrevista para ingressar no programa, expus o pré-projeto à então decana da cadeira de italiano Loredana de Stauber Caprara, a qual, com muita solicitude, pediu-me prudência ao tratar a questão linguística e, ao fim da entrevista, declarou: "Este é um tema apaixonante".

Tempos depois eu viria a perceber que, de fato, a paixão não é outra coisa senão a essência do projeto. Em primeiro lugar, foi a paixão pelo ensino da língua italiana que me inspirou a encontrar um assunto novo, ousado e desafiador como esse, ou seja, o da utilização da ópera lírica como instrumento de ensino do italiano LE.

Como veremos no primeiro capítulo, o ensino das línguas estrangeiras está baseado em duas dicotomias. A primeira delas separa o estudo da língua do estudo da cultura, como 
forma de sistematizar o ensino e promover uma maior organicidade curricular. De acordo com Mauro Pichiassi (1999), a abordagem essencialmente linguística foi superada, mas a sua organicidade ainda se faz fundamental na abordagem metodológica do ensino de língua estrangeira. Como consequência da separação entre língua e cultura, temos a inevitável dicotomia langue/parole ${ }^{1}$, já que a língua veiculada nas aulas praticamente não ultrapassa o banal comunicativismo, em que os eventos linguísticos são tratados como discursos de fácil repetição e "vazios" de significado.

Portanto, mais do que uma novidade temática, a proposta do trabalho com a ópera lírica deverá servir para amenizar - ou, até mesmo, apagar - essas dicotomias, o que só pode ser conseguido se a concepção de língua estrangeira superar o viés puramente comunicativo e tender para a análise do discurso, para o estudo da enunciação e para a busca da construção do sentido do texto.

De fato, a intenção é fugir do pretexto, ou seja, a ópera não será utilizada como escusa para se ensinar gramática. Ao contrário, é preciso inseri-la no currículo de língua estrangeira preservando a sua potencialidade estética, para que possamos perseguir também as metas formativas, além das metas linguísticas já existentes.

Por isso, ainda no primeiro capítulo, tentarei situar a ópera lírica no âmbito educacional e, em seguida, acenarei para a função que ela deverá assumir ao ser transportada para o contexto de língua estrangeira, na tentativa de dessacralizar o gênero e transformá-lo em um eficaz instrumento para a prática e o aprimoramento do idioma italiano e, acima de tudo, para promover a formação discente.

Para proceder a tal investigação, porém, é preciso conhecer a fundo o que é o melodrama, ou o dramma per musica, como se costumava chamar esse gênero de que todos já ouviram falar, mas poucos conhecem de fato. Assim, no segundo capítulo, o leitor poderá entender por que a ópera apaixonou tantas gerações, seja como arte erudita, seja como arte popular, além de entender por que ela pode ser convertida em instrumento de ensino da língua estrangeira tal qual o cinema ou a literatura.

A partir de um panorama histórico da ópera, passaremos em revista grandes nomes da ópera mundial, de Claudio Monteverdi a Luciano Chailly, primeiro com o objetivo de

\footnotetext{
${ }^{1}$ Segundo o linguista francês Ferdinand de Saussure (1969), a língua (langue) é um sistema de valores que se opõem uns aos outros e que está depositado como produto social na mente de cada falante de uma comunidade. A fala, ou o discurso (parole) é a concretização da língua e, portanto, necessária para o seu estabelecimento.
} 
conceptualizar o gênero nos diversos períodos de sua manifestação cultural e artística e, segundo, visando ao (re)conhecimento da sua essência, para proceder com maior propriedade à indagação metodológica acerca do objeto.

A busca pelo que se pode definir "essência da ópera lírica" deve ser feita na interseção entre dramaturgia e lirismo, já que não é somente o poder da música e da impostação da voz que confere a tensão ao gênero operístico. Etimologicamente, a palavra "melodrama" significa "drama cantado", o que explica o fato de a tensão da música e do canto existir em função de um enredo dramático, que impele ora à récita, ora ao desafogo das paixões de suas personagens.

Por isso, não trabalharemos apenas a parte lírica, mas tudo o que envolve a significação da ópera. É nesse sentido que a proposta de se trabalhar esse gênero em sala de aula prevê a identificação do aluno pela catarse, já que, em sentido aristotélico, "drama" está relacionado à ação. Portanto, não se espera que o aluno se identifique com a forma de expressão lírica da ópera, mas com as histórias ricas em pathos, que induzem a sentimentos de piedade ou tristeza. Teria dito Herta Herzog : “[o]s espectadores, ao se identificarem, e a seus problemas, com os sofredores heróis e heroínas dos melodramas, outorgam grandeza às suas próprias aflições cotidianas e afirmam sua superioridade sobre outras pessoas que não viveram experiências emotivas tão profundas" (OROZ, 1992, p.32).

Certamente, a comoção estética provirá da descoberta dos mecanismos de produção do drama, por parte dos alunos, e dos efeitos de sentido para os quais eles serão chamados a reagir.

O terceiro capítulo mostrará a importância formativa e pedagógica de se apresentar a ópera como um material autêntico, isento de qualquer adaptação, a alunos que ainda não dominam a língua estrangeira. Em contrapartida, descobriremos como esse material poderá se tornar um input compreensível ${ }^{2}$, de modo que o aluno possa erigir seus conhecimentos sobre todo o drama ou parte dele, apoiando-se nas diversas linguagens que a ópera traz, ou seja, nos sons, na imagem e, também, no próprio texto.

Portanto, antes de tudo, discutiremos as vantagens de se trabalhar um gênero tão rico e completo quanto a ópera, o qual nos permite usar até mesmo a sua complexidade estética a favor do ensino e da formação discente.

\footnotetext{
${ }^{2}$ Para Stephen Krashen (1989), a aquisição linguística se dá somente se o aluno recebe um input compreensível e seu filtro afetivo está suficientemente baixo, a ponto de permitir a entrada do próprio input.
} 
A partir das estratégias que os alunos deverão mobilizar diante do material autêntico, seguindo um percurso didático que vai "da emoção à razão", o sincretismo do som e da imagem exigirá primeiro apenas a percepção da linguagem patêmica (relativa ao pathos e, portanto, emocional) de cada cena. Posteriormente, e apoiados nessa linguagem, os alunos serão chamados à intelecção linguística da cena, que acontecerá na fase racional.

Nessa fase, em que se confrontará o texto escrito, a complexidade da língua arcaica será trabalhada a partir de paráfrases que se configurarão no âmbito das tarefas. Com isso, espera-se instigar aos poucos os mecanismos parafrásticos naturais dos alunos para enfrentar, de um modo geral, a linguagem verbal com maior autonomia.

Ao final do capítulo, analisaremos os benefícios que o trabalho com a ópera poderá trazer aos alunos de italiano LE, bem como seus reflexos na vida de aluno e, em sentido mais amplo, no espírito humano.

O penúltimo capítulo aprofunda a questão metodológica e fundamenta o percurso didático supracitado a partir dos preceitos semióticos de análise, sobretudo no que concerne aos estudos sobre a Semiótica das Paixões, um postulado greimasiano que, grosso modo, trata o nível profundo do texto - em que se verifica a linguagem patêmica - como a tensão que move à ação.

À luz da abordagem semiótica será possível didatizar o objeto sem recorrer à adaptação, porque se partirá da percepção da música e da encenação para se chegar ao entendimento da ação propriamente dita confirmada pelo texto escrito.

Essa fase de análise é fundamental para que possamos, em seguida, discutir sobre os objetivos didáticos que envolvem o trabalho com a ópera lírica em sala de aula, dado que, reiterando o conteúdo do primeiro capítulo, nossa metodologia não versará a gramática da língua, mas sim a gramática do texto.

De acordo com Balboni (2006b), “cada gênero possui uma gramática própria: em um romance policial devem coexistir o criminoso e aquele que o persegue e, ao final, deveremos encontrar o triunfo da justiça". No caso da ópera lírica, essa gramática é mais rica e complexa porque ela se concretiza não apenas no âmbito do enredo propriamente dito, mas também na estética da música, da poesia e da encenação, determinando e redundando o sentido do texto.

Além dos objetivos específicos, os resultados da análise do texto permitirão que se estabeleça o público, o modo de organização didática do corpus a ser trabalhado, as técnicas a 
serem empregadas e, enfim, os tipos de avaliações apresentáveis para a proposta. Assim, todos estes itens serão tratados com o devido afinco ainda no capítulo 4.

Finalmente, o último capítulo trará o modelo prático de uma unidade didática sobre um drama completo de Giuseppe Verdi e Francesco Maria Piave: Rigoletto, de 1851.

O título do curso, "Rigoletto: per gli amanti della lingua e della cultura italiana", já sugere a presença da paixão (“amanti”) e a articulação entre os estudos linguísticos e culturais ("lingua e cultura") na didática de uma ópera lírica.

Portanto, desde as motivações que levaram à escolha dessa ópera até as avaliações implicadas, o leitor poderá comprovar o empenho de adesão entre teoria e prática, inclusive no sentido de poder testar o grau de inteligibilidade linguística que o discente poderá alcançar a partir do trabalho didático proposto, dado que essa ópera veicula a língua do século XIX.

Além disso, ao final da proposta, serão apresentados os resultados obtidos durante a aplicação da primeira versão do curso, aprimorada, sobretudo, a partir de estudos mais aprofundados acerca das teorias que envolvem a didatização do objeto. Mesmo assim, a positividade dos dados já poderá demonstrar os níveis de eficácia da utilização da ópera lírica como instrumento de ensino nas aulas de italiano LE. 


\section{LÍNGUA E CULTURA NAS AULAS DE LÍNGUA ESTRANGEIRA}

"A complexidade da linguagem é a mesma complexidade do homem."

Renzo Titone

No ensino das línguas estrangeiras, o meio e o fim coincidem: ensina-se a língua valendo-se do código dessa mesma língua. Entretanto, a concepção que se tem de "língua" é fundamental para descrever o que, de fato, é ensinado.

De um modo geral, o ensino-aprendizagem em língua estrangeira (LE) sempre esteve associado ao ensino da gramática, ou ao ensino sistemático dos elementos constitutivos de uma língua. Seja pelo método formalístico, que dominou muitas escolas até os anos $1970^{3}$, seja por meio da língua vista como instrumento (pragmático) de comunicação, a gramática sempre conduziu os cursos LE, mesmo implicitamente, porque, para a educação linguística, "não existe ensino da língua que não seja também, e contemporaneamente, ensino da gramática (FREDDI, 1994).

De fato, a ordem de progressão das dificuldades dos inputs é determinada pela progressão gramatical ${ }^{4}$. Hoje, dificilmente encontraremos um manual ${ }^{5}$ de unidades intituladas "Presente", "Pretérito Perfeito", "Imperfeito", "Futuro" e "Subjuntivo", o que não quer dizer que, na unidade "Muito prazer", o aluno não estude apenas o presente; em "Minha viagem de férias", apenas o passado; em "Infância", apenas o imperfeito; em "Previsões para o próximo ano", apenas o futuro; e, em "Se eu fosse você", apenas o subjuntivo.

Entretanto, nos últimos anos, a concepção que se tem de língua estrangeira como simples instrumento de comunicação tem evoluído para uma visão mais abrangente (e complexa) da língua, com forte tendência à inclusão dos problemas formativos e educacionais nos pragmáticos já existentes. Isso equivale a dizer que, além das "situações cotidianas", devemos considerar também os "gêneros discursivos"; a aém do estudo da "frase", devemos

\footnotetext{
${ }^{3}$ Para um panorama dos principais métodos e abordagens do século XX, leia-se Balboni (2006a).

${ }^{4}$ Segundo Tracy D. Terrel (1977), "em uma aula tradicional, o aluno expande a sua gramática com uma regra por vez, aprendendo cada uma da melhor forma possível e progredindo de um produto simples para outro mais complexo". "(...) in the traditional classroom the student expands his grammar one rule at a time, learning each as perfectly as possible and progressing from a simple to a more complex output".

${ }^{5}$ Refiro-me ao manual do aprendiz, acompanhado ou não de subsídios sonoros - áudio ou vídeo - e, provavelmente, de um "livro do professor".

${ }^{6}$ É interessante notar que Balboni (2006a) não fala de "gêneros discursivos" dentro da educação linguística, mas de "gêneros comunicativos".
} 
considerar também o estudo do "texto"; e, além do estudo indutivo da gramática, devemos considerar também o estudo da cultura. O resultado será um ensino da língua estrangeira cada vez mais próximo do ensino da língua materna.

A aprendizagem de uma língua estrangeira é obstruída pela visão que, habitualmente, tem-se dela - exatamente como língua estrangeira. Visão, geralmente, confirmada pela linguística. Outro grande obstáculo é a redução do estudo do conhecimento da língua estrangeira à função comunicativa. ${ }^{7}$ (PONZIO, 2001, p. 8).

Portanto, mesmo que ainda não seja possível perceber uma mudança efetiva na abordagem do ensino-aprendizagem das línguas estrangeiras, que continua sendo comunicativa e conduzida pela gramática, podemos dizer que a cultura é o novo elementochave na elaboração do currículo LE, tendendo a tornar-se tão importante quanto a língua (BALBONI, 2006a).

Em linhas gerais, podemos afirmar que, nas últimas décadas, a cultura teve um papel pouco relevante no ensino-aprendizagem LE, ao menos na sua acepção de produtos artísticos ou intelectuais da tradição clássica, como a música, a pintura, a literatura, a poesia, etc. De fato, ela está em segundo plano em relação ao estudo da língua em um curso LE, cuja programação "deve privilegiar a língua sincrônica do nosso tempo, pelo menos até que o aprendiz não a tenha apreendida e consolidada" e, mais do que isso, deve privilegiar a língua na sua valência comunicativa, que é "hoje unanimemente considerada a valência primária da língua" (FREDDI, 1994, grifo meu).

Infelizmente, tal privilégio acarreta a redução/rebaixamento da cultura por meio de ilustrações comportamentais dos nativos em determinadas situações do cotidiano. Além de banais, esses quadros estão a serviço de uma língua funcional desprovida de elementos expressivos que lhes confiram qualquer valor estético. São, enfim, simulacros do real, dotados de verossimilhança, mas destituídos de mímesis, entendida como a representação artística da realidade.

A educação linguística dá por satisfatório o fato de a língua ser, por definição própria, o produto da cultura de um povo, mesmo que ela seja manipulada para fins didáticos.

\footnotetext{
7 "L'apprendimento di una lingua straniera è ostacolato dalla visione, sopra descritta, che generalmente si ha di essa appunto come lingua straniera, anche se la linguistica l'ha generalmente confermata. Un ostacolo di non minore entità è la riduzione dello studio della conoscenza della lingua straniera alla funzione comunicativa." Essa e as próximas traduções para o português são de minha autoria.
} 
Acredita-se que a cultura seja transmitida de modo suficiente por meio dos atos comunicativos, de expressões correntes e, enfim, da língua cotidiana. Portanto, a língua como produto da cultura literária só poderá aparecer no ensino LE depois que o aluno tiver alcançado um alto nível de conhecimento da língua italiana de todos os dias.

\begin{abstract}
A língua pensada para fins estéticos não pode constituir o principal tipo de língua apresentado aos alunos (como nos tradicionais colégios, onde (pre)domina a literatura), nem pode ser ignorada como se fosse um aspecto inútil ou sofisticado em nome de uma abordagem comunicativa degradada a banal comunicativismo. ${ }^{8}$ (BALBONI, 2006a, p. 61).
\end{abstract}

A partir disso, podemos dizer que, nas aulas de língua estrangeira, a aculturação existe, mas constitui apenas uma meta didática da educação linguística, e não uma meta formativa, visto que a cultura se põe mais como problema comunicativo do que como problema de formação da personalidade do discente. Em outras palavras, é bem possível que, após ter percorrido todo o processo didático em LE, o aluno seja capaz de reconhecer os modelos culturais e os valores de civilidade do povo que fala a língua estrangeira. Entretanto, provavelmente, ele não terá desenvolvido o senso crítico para se posicionar diante tais modelos e valores ${ }^{9}$.

Segundo Freddi (1994, p. 35), “a educação literária é uma prolongação da educação linguística na direção das metas formativas". Portanto, é essencial que aquela intervenha sobre esta para que a cultura se (re)signifique no âmbito educacional e formativo do discente, na tentativa de amenizar a dicotomia língua/cultura dentro do ensino LE.

Sobre essa última observação, são necessárias algumas ressalvas. A primeira delas diz respeito ao conceito sobre o ensino da literatura, que evoluiu do trabalho com textos literários escritos para o trabalho com as diversas formas de expressão que fazem um uso literário da língua, como é o caso do cinema, do teatro e, também, do melodrama (BALBONI, 2006b). Em segundo lugar, a literatura não deve ser levada para a sala de aula como amostragem de língua modelo ${ }^{10}$ e nem de língua comum ${ }^{11}$. Ela deve ser estudada como "linguagem e

\footnotetext{
8 "La lingua pensata per scopi estetici non può costituire il principale tipo di lingua presentato agli studenti (come nei tradizionali trienni dei licei, in cui domina la leteratura) né può essere ignorata come se fosse um aspetto inutile o snobistico in nome di um approccio comunicativo degradato a banale comunicativismo."

${ }^{9}$ Cf. ECO, 2003.

${ }^{10}$ Até os anos quarenta, as línguas eram estudadas com finalidades exclusivamente culturais para que o aluno se aproximasse das grandes obras da literatura sem o trâmite da tradução. No método gramático-tradutivo, a língua literária representava o modelo linguístico perseguido pelo ensino/aprendizagem LE.
} 
analisada como construção de sentido(s), a partir dos mecanismos linguísticos que a constituem." (SANTORO, 2007, p. 24).

A dicotomia língua/cultura incide em outra dicotomia, a langue/parole, visto que o ensino LE tenderá à sistematização linguística ou, pelo menos, promoverá apenas discursos "vazios" de significado. De fato, as situações apresentadas pelos manuais por meio de diálogos $^{12}$ ou de textos escritos elaborados para fins didáticos produzem enunciados incompletos. Como produto da enunciação, eles deveriam trazer, além das marcas formais, marcas que denotam a presença de um sujeito social e histórico, apresentado por meio de um discurso que se estrutura a partir de outros discursos e posicionamentos ${ }^{13}$.

Em outras palavras, os diálogos supracitados não possuem nenhum referente histórico ou social que possa dar conta do estado subjetivo do enunciador ${ }^{14}$ no momento da enunciação. Logo, resultam indeterminadas as condições que levaram aquele 'eu' a produzir aquele enunciado àquele 'tu', o que nos impede de delimitar as suas reais possibilidades interpretativas.

Desse modo, mesmo com a intenção de se partir da parole, por meio de situações verossímeis, o método comunicativo veicula enunciados planos com muitas estruturas de repetição, já que não podem contar plenamente com a enunciação, aproximando-se, assim, mais da langue. Foram produzidos para serem utilizados por qualquer falante que se encontre em uma situação semelhante, como se os eventos não fossem únicos e singulares, e não dependessem dos estados subjetivos dos comunicantes. Por isso, alguns teóricos preferem orientar seus estudos acerca do ensino/aprendizagem LE com base em contextos também únicos e singulares, como os literários.

[...] não é possível separar o estudo da língua do estudo da literatura realizada nessa língua. Isso porque o estudo das enunciações, dos discursos, dos textos, das linguagens e dos gêneros discursivos em que a língua vive é enormemente facilitado pela sua configuração literária. ${ }^{15}$ (PONZIO, 2001, p. 8, tradução nossa).

\footnotetext{
${ }^{11}$ Os alunos devem ser conscientes da literariedade de um texto.

${ }^{12}$ Refiro-me aos diálogos registrados em estúdio que simulam uma conversação real entre nativos da língua italiana sobre situações cotidianas.

${ }^{13}$ Cf. BRAIT, 2008.

${ }^{14}$ Entende-se por enunciador o actante implícito responsável pela emissão do discurso. Portanto, ele se distingue do sujeito da enunciação, ou seja, o "eu" explícito que fala no discurso.

15 “[...] non è possibile separare lo studio della lingua dallo studio della letteratura in essa realizzata. Ciò perché lo studio delle enunciazioni, dei discorsi, dei testi, dei linguaggi e dei generi discorsuali in cui la lingua vive è enormemente agevolato dalla lora raffigurazione letteraria."
} 
Para concluir a discussão sobre o papel da cultura no ensino LE, gostaria de questionar sobre o real valor da cultura enquanto mera ilustração do cotidiano e de uma língua selecionada de acordo com a competência do aprendiz. Até que ponto a cultura é explícita, objetiva e denotativa? Até que ponto o simples contexto situacional permite transmitir a cultura de um povo ${ }^{16}$ ? Até que ponto uma língua privada de enunciação pode ser "espelho e veículo de modelos culturais, além de instrumento indispensável para produções 'nobres' como a poesia, a filosofia, etc.", como afirma Freddi (1994, p. 27)?

\subsection{A CULTURA NO CURRÍCULO DE LÍNGUA ESTRANGEIRA}

"Um currículo, como diz a etimologia, é um percurso. Por definição, um percurso leva a uma meta."

Paolo Balboni

Se quisermos alcançar também a meta formativa no ensino-aprendizagem de línguas estrangeiras, devemos discordar da opinião daqueles que pregam a introdução do texto literário apenas em níveis avançados, inclusive do Quadro Europeu Comum de Referência para as Línguas ${ }^{17}$, e reavaliar nossa "gramática pedagógica" ${ }^{18}$ em busca de um maior equilíbrio entre os vários papéis que a língua deve assumir, desde o início, em um currículo LE.

A nosso favor está o fato de que a língua, na sua valência expressiva, não é somente uma reunião de aspectos formais. Ao contrário, ela abrange todas as outras funções linguísticas, como a intencionalidade, a interação social, a identidade, bem como ser a expressão de uma cultura e um instrumento do pensamento. Além disso, a literatura também trata do cotidiano, trazendo temas universais como o amor, a corrupção, o papel das mulheres na sociedade, além de diálogos entre pessoas comuns em um bar, em um restaurante, no

\footnotetext{
${ }^{16}$ Para Malinowisk, tanto o contexto de uso quanto o contexto cultural são fundamentais para o entendimento de um texto (HALLIDAY; HASAN, 1989, grifo meu).

${ }^{17}$ O Quadro Europeu Comum de Referência para as Línguas atribui apenas aos aprendizes do nível mais alto de conhecimento de uma língua estrangeira, ou seja, do nível C2, a capacidade de "compreender e interpretar de modo crítico praticamente todas as formas de linguagem escrita, inclusive de textos literários e não literários abstratos, estruturalmente complexos e muito ricos de expressões coloquiais". Quadro comune europeu di riferimento per le lingue: apprendimento insegnamento valutazione, (2004, p. 87, grifo meu).

${ }^{18}$ Cf. GIUNCHI, 1990 e CILIBERTI, 1991.
} 
teatro, etc., mantendo, assim, a proposta de se fornecer inputs inspirados nas futuras experiências linguísticas do aprendiz LE. A literatura está impregnada de cotidianidade, a ponto de veicular, também, uma língua funcional.

Entretanto, antes de se adotar o texto literário em sala de aula, é preciso considerar fixados os objetivos didáticos - alguns fatores que permitam (ou impeçam) a sua realização didática. Em outras palavras, é necessário estabelecer os parâmetros para torná-lo um input compreensível.

Da mesma forma que o contexto de um texto literário (que além de situacional é também social e histórico) pode contribuir para a transmissão da cultura do povo que fala a língua estrangeira, um texto literário recortado (e, portanto, desprovido de seu contexto pleno) pode se tornar enigmático aos olhos do aluno. Por isso, é fundamental estar sempre atento à relação proporcional entre contexto e estética, principalmente nos primeiros níveis da aquisição linguística.

De fato, quanto mais rebuscada a linguagem do texto, maior o grau de contexto em que o aluno deverá se apoiar, já que ele funciona como instrumento de controle contra a angústia dos aprendizes ${ }^{19}$. O ideal seria trabalhar toda a obra, no caso do romance; todo o filme, no caso do cinema; todo o melodrama, no caso da ópera, ou, então, adotar textos curtos, como contos, poesias ou curtas-metragens, de modo que sejam totalmente preservados o contexto e a organicidade do input.

A opção pelo recorte, por sua vez, implicará em uma maior indução do contexto por meio das tarefas (pré-tasks e tasks). Caso contrário, tende-se a incorrer no mesmo erro dos manuais, que inserem trechos de obras literárias como um pretexto para se ensinar a gramática.

\footnotetext{
${ }^{19}$ Tratarei com maior afinco essa questão no terceiro capítulo, que discorre sobre a apresentação da ópera em sala de aula.
} 


\subsection{A ÓPERA NA EDUCAÇÃO E NO ENSINO}

"O conhecimento não pode ser uma cópia, visto que é sempre uma relação entre objeto e sujeito."

Jean Piaget

Para fugir do pretexto, seria muito interessante observar o modo como as instituições de ensino lidam com a "educação literária" e, a partir daí, estabelecer nossas metas. Com relação ao nosso objeto, podemos dizer que a inserção do gênero operístico na Itália deve-se a uma legítima preocupação: a ópera é um grande patrimônio cultural do qual os jovens estão arriscados a ficarem excluídos se não houver uma adequada oferta educativa.

No século XX, a ópera lírica sofreu um lento declínio, observado tanto na quantidade e qualidade dos novos espetáculos, quanto na sua popularidade entre as novas gerações. De fato, com tantas outras possibilidades atuais de arte e entretenimento, o melodrama perdeu sua vitalidade entre os jovens, o que tem suscitado várias iniciativas, inclusive no âmbito educacional, no sentido de garantir o público dos espetáculos, despertar o interesse das futuras gerações para o gênero e, em sentido mais amplo, formar o aluno. Vejamos alguns exemplos:

\section{- Opera domani ${ }^{20}$}

Define-se como um projeto para a produção de óperas líricas introduzidas por percursos didáticos, que pretende aproximar os alunos do ensino fundamental da ópera lírica. Todos os anos, a Associação Lírica e Concertista italiana (As.Li.Co) seleciona uma ópera lírica a ser apresentada aos meninos e meninas de várias escolas italianas, a fim de prepará-los para participar ativamente do espetáculo. De fato, as crianças intervêm durante a peça, cantando para a plateia algumas páginas da ópera e executando simples movimentos, tudo ensaiado nos meses que antecedem a apresentação. Além disso, os alunos que participam do projeto podem se inscrever no concurso anual da revista Amadeus, que premia os melhores temas da temporada. As apresentações também são filmadas e disponibilizadas em DVD.

Outra característica do projeto refere-se ao treinamento dos professores, aos quais são oferecidos cursos de formação reconhecidos pelo Ministério da Educação (de acordo com o

\footnotetext{
${ }^{20}$ As informações sobre este projeto encontram-se no site $<$ http://www.operadomani.org $>$, acessado em 19/02/2009.
} 
artigo 66 do vigente C.C.N.L ${ }^{21}$ e os art. 2 e 3 da Diretriz n. 90/2003) para que possam guiar, de forma consciente, o trabalho das crianças.

O Opera domani foi criado em 1997 em colaboração com a região da Lombardia e já ganhou vários prêmios. A cada ano, envolve cerca de 50.000 alunos e 2.200 professores de toda a Itália. Além disso, o projeto é membro do R.E.S.E.O. (Rèseau Europèen des Services Èducatifs des maisons d'Opèra), um circuito que reúne os projetos educativos dos teatros de ópera da Europa.

\section{- Gruppo di Interesse Scala (G.I.S.) $)^{22}$}

Os G.I.S. são grupos autônomos que se formam a partir da colaboração com o Serviço de Promoção Cultural do Teatro alla Scala, de Milão, com o objetivo de promover o estudo da música clássica e da lírica, além da participação aos espetáculos teatrais com custo de ingresso reduzido. Eles podem ser constituídos por instituições escolares, bibliotecas cívicas, assessorados à cultura, grupos municipais ou universidades de terceira idade.

Para que se constitua um G.I.S., é necessário que as autoridades competentes nas diversas instituições designem um Operador Cultural Responsável que deverá, além de criar o grupo por meio de inscrições, programar e realizar percursos formativos que tenham como tema o Teatro alla Scala e os espetáculos propostos. O Operador Cultural realizará encontros, audições guiadas, seminários e outras iniciativas visando ao crescimento cultural e à participação consciente dos adeptos do grupo nas peças. Deverá, também, manter contato regular com o Serviço de Promoção Cultural, ao qual apresentará um relatório ao final da temporada.

Atualmente, muitas escolas italianas recorrem à formação de G.I.S. para promover a sensibilização dos alunos para a ópera, estruturando suas atividades, muitas vezes interdisciplinares, a partir do calendário do Teatro alla Scala. São organizados encontros de leitura, conversação, audições de trechos musicais, execuções de música ao vivo, quizzes musicais, etc., com a participação de artistas e docentes especialistas no campo literárioestético-musical.

- Outras iniciativas

\footnotetext{
${ }^{21}$ Contratto Collettivo Nazionale di Lavoro.

${ }^{22}$ As informações apresentadas a seguir foram selecionadas do site $<$ http://www.teatroallascala.org $>\mathrm{em}$ $19 / 02 / 2009$
} 
Em todo o mundo, são cada vez mais comuns os cursos de cultura que oferecem incursões no mundo da ópera lírica e apresentam a um público heterogêneo, que se divide entre amantes do gênero e curiosos em conhecê-lo, os grandes autores/compositores e as grandes produções de todos os tempos.

Infelizmente, muito mais raras são as iniciativas que tentam articular o ensino da língua italiana ao melodrama; e, quando isso acontece, as aulas restringem-se à exposição do objeto em italiano, com total enfoque na cultura ${ }^{23}$. Ou o contrário, como é o caso de alguns $\operatorname{livros}^{24}$ que usam a ópera como pretexto para se ensinar a língua, já que partem de uma abordagem Focus on FormS ao invés de Focus on Form ${ }^{25}$.

Portanto, esta pesquisa aparece como uma novidade, em que língua e cultura receberão o devido enfoque e estarão sempre engajadas em busca da aquisição do input por parte do aluno, o qual deverá apreender o sentido do texto a partir da linguagem que ele trouxer, sempre apoiado no contexto. Além de se levar o aluno à aquisição de uma maior autonomia linguística, pretende-se chegar a uma maior autenticidade da língua italiana, inclusive na sua valência comunicativa, visto que ela será empregada para falar a todo o momento do objeto.

\footnotetext{
${ }^{23}$ É o caso do novíssimo livro Tendenze italiane $n$. 22, cujo capítulo intitulado "L'italiano del bel canto" é "dedicado ao ensino do italiano a cantores estrangeiros ou a estrangeiros que tenham, por motivos pessoais ou profissionais, interesse pela ópera lírica". Além dessa especificidade, os pré-requisitos para o acesso às atividades didáticas são o "bom conhecimento de base da língua italiana, pelo menos de nível B2, e um conhecimento inicial dos textos dos libretos de ópera". Catálogo disponível em $<$ http://www.guerraedizioni.com/books/index.cfm?node=0,1,1020,1257>. Acesso em 5 abr 2009.

${ }^{24}$ No livro L'italiano all'opera. Attività linguistiche attraverso 15 arie famose, "o objetivo do volume não é o de instruir sobre o melodrama, mas por meio dele". Portanto, "a ária de ópera torna-se ponto de partida para atividades de áudio, de leitura, de discussão e de reflexão gramatical" (CARRESI et. al., 1998, p.9).

${ }^{25}$ Long (2000, p. 185) descreveu o Focus on FormS (FonFS) como um método tradicional em que as aulas constituem-se de itens linguísticos pré-selecionados e sequenciais. Ao contrário, o Focus on Form (FonF) integra a força do FonFS com o Focus on Meaning para trazer a atenção do estudante para os elementos linguísticos contextualizados, focalizando as aulas no significado do texto e na comunicação.
} 


\subsection{A ÓPERA NAS AULAS DE LÍNGUA ESTRANGEIRA}

"Não levamos bastante em conta que língua e cultura são duas modalidades paralelas de uma atividade mais fundamental; refiro-me àquele hóspede presente entre nós, embora ninguém tenha sonhado sequer em convidálo para as nossas discussões: o espírito humano."

Lévi-Strauss

O ensino da ópera nas aulas de língua estrangeira pretende alcançar as três metas educativas gerais, a saber: a autopromoção, a socialização e a aculturação.

A primeira, ligada ao "eu", corresponde ao modelo egodinâmico elaborado por Renzo Titone (1976). Refere-se ao crescimento e à realização do indivíduo, ao enriquecimento do espírito humano pela concretização de um projeto individual. Portanto, espera-se aculturar por meio do contato com a ópera e do seu entendimento. Saber/Compreender por que gosta/gostou da ópera e saber que gosta porque sabe como funciona, satisfaz o ego, dá segurança e autonomia para escolher e avaliar outras obras.

A socialização, que liga o "eu" ao "tu”, é restritiva, já que "a literatura não se propõe essa meta" (BALBONI, 2006a, p. 15). Refere-se apenas ao trabalho em classe, à relação entre o docente e os alunos e dos alunos entre si. Por outro lado, com o estudo do gênero, espera-se que o aluno possa assistir aos espetáculos como um italiano e, portanto, possa socializar-se e discutir ópera também com o público italiano.

Por fim, temos a aculturação, que liga o "eu" ao "mundo" e é a mais evidente de todas as nossas metas. "Significa abrir uma dimensão diacrônica da cultura italiana e compreender por que a Itália é hoje o que é" (BALBONI, 2006a, p. 16). Trataremos desse aspecto ao discutir sobre o valor da cultura enquanto expressão de uma sociedade e expressão do homem.

Assim, este procedimento didático pretende enaltecer o espírito humano dos alunos 1) fornecendo instrumentos de análise para a compreensão e interpretação do melodrama, 2) estimulando o senso crítico e 3) ajudando a criar um gosto pessoal. Tudo isso sem esquecer que o ensino da ópera estará inserido no ensino da língua e que deverá, portanto, contemplar também as metas linguísticas, correspondentes à individualização das características formais da linguagem operística, além da aquisição de um maior repertório e uma maior autonomia linguística e comunicativa por parte dos alunos. 


\section{O GÊNERO ‘ÓPERA' E SUAS IMPLICAÇÕES DIDÁTICAS}

"Como perceber a realidade exterior, se percebemos o contato com a realidade interior?"

Marsilio Ficino

A ópera constitui um gênero riquíssimo de possibilidades didáticas pela sua organicidade, tanto em nível literário quanto em nível linguístico. No sentido filosófico, estamos falando de um gênero cuja organização é entendida na sua complexidade, com incidência na unicidade e integração de elementos criativos distintos, que dão à obra um caráter multifacetado e multifuncional.

No plano literário, essa organicidade se dá por meio da unidade do texto, em sentido aristotélico, por encerrar uma só ação, inteira e completa, com princípio, meio e fím, assemelhando-se a um organismo vivente. Dessa forma, a obra poética (neste caso, a ópera) é capaz de suscitar o prazer (Aristóteles, 2006). Além disso, os alunos poderão, com base na sua enciclopédia literária, reconhecer facilmente os elementos antagônicos do texto sobretudo porque a ópera tem a característica de hiperbolizar as emoções e, consequentemente, as ações - e, a partir disso, fazer hipóteses acerca dos rumos da trama.

No plano linguístico, a organicidade é representada pelo sincretismo das linguagens verbais e não-verbais, já que temos "música e encenação conscientes do significado da trama" (PEIXOTO, 1986, p. 62). A ação didática é facilitada, portanto, com base na redundância das linguagens, em que uma será o suporte da outra: fornecerá contexto à outra.

Mas o que é a ópera? E qual a sua relevância para a cultura italiana?

Em primeiro lugar, trata-se de uma arte italiana por excelência, um dos símbolos mais prestigiosos do mady in Italy.

A ópera nasceu na Itália. E para muitos continua, e continuará para sempre,
propriedade privada dos italianos. Músicos em diferentes países, em
diferentes épocas, escreveram e escrevem não somente segundo os modelos
tradicionais italianos como também alguns só compõem com libretos
escritos em italiano (PEIXOTO, 1986).

Por isso, a ópera é parte da representação da Itália, e dos italianos, no mundo. Sem dúvida, o gênero é reconhecido por associação imediata à cultura italiana. Até mesmo o modo 
(estereotipado) de ver os italianos como um povo passional e que fala cantando deve-se, em parte, ao melodrama ${ }^{26}$.

De fato, trata-se de um gênero artístico genuinamente italiano exportado para outros países, o que nos permite considerá-lo, também, um dos responsáveis pela influência cultural da Itália na arte e, sobretudo, na música de outros países ocidentais, como a Alemanha, a França, a Espanha e até mesmo o Brasil.

A propósito de interculturalidade, não podemos esquecer que a cultura italiana desembarcou no Brasil com a vinda dos imigrantes, os quais trouxeram a ópera para o cotidiano de muitos brasileiros.

\begin{abstract}
A música italiana, tanto as cançonetas como as árias de ópera, faziam parte do nosso cotidiano. Nós, crianças e adultos, as ouvíamos no rádio, nas vitrolas de todas as casas, e, lógico, ao vivo executadas pelos frequentadores das cantinas e pizzarias que lá se reuniam para comer e cantar, e que eram em enorme número no bairro (informação pessoal) ${ }^{27}$.
\end{abstract}

Então, não é justo afirmar que a ópera é arte para poucos entendidos. Ao contrário, ela sempre foi popularíssima, principalmente no seu país de origem. É provável que somente na Itália se ouça, ainda hoje, um encanador consertar um vazamento cantando a plenos pulmões a ária do Duque em Rigoletto: "La donna è mobile, qual piuma al vento..." (SUHAMY, 1997). E o que dizer da popularidade da ária "Va' pensiero", considerada o segundo hino nacional da Itália?

Com efeito, a ópera é a expressão de uma sociedade. Os quatro séculos de vida em que a ópera lírica narrou mitologia, eventos históricos, dramas e romances literários exprimem quatro séculos de vida da sociedade italiana. Trata-se de um imenso material de cunho social-histórico que não pode ser desperdiçado com o pretexto de que a ópera é erudita, hermética e, portanto, inacessível ao aluno, sobretudo ao jovem.

O dia 6 de março de 1637 assinala uma das datas mais importantes para a História da Ópera: a da inauguração, no bairro veneziano de San Cassiano, de um teatro aberto ao público, pertencente à família Tron. A partir desse momento, a mais italiana das formas de expressão musical abre os braços a todas as camadas sociais e, durante muito tempo, será a forma privilegiada de expressão de seus sentimentos, aspirações, fantasias e visão do mundo.

\footnotetext{
${ }^{26}$ Reporto-me aos slides reunidos sob o título "O italiano que canta", assinado por Paolo E. Balboni, disponível no endereço $<$ http://www.consatene.esteri.it/NR/rdonlyres/EE01AD30-3107-467C-A3D497969A1A4E32/6600/BalboniLitalianocantato.ppt>, acessado em 22/11/2008.

${ }^{27}$ Testemunho de Sergio Casoy, ministrante da disciplina História da Ópera, pela Escola de Comunicações e Artes (ECA), da Universidade de São Paulo (USP). O trecho faz parte de uma entrevista exclusiva para este trabalho, realizada em 28 de agosto de 2008.
} 
Nesse dia 6 de março, a ópera converte-se em um dos mais preciosos espelhos da vida social (COELHO, 2000, p. 83).

Por outro lado, a ópera deve ser vista também como uma arte universal, como a expressão do homem, dos seus sentimentos, em busca da sua constituição de sujeito. Enquanto arte humanística sincrética, ela reúne em si as definições da literatura, da música e do teatro.

Em suma, por todo o seu valor cultural, histórico, estético e moral, a ópera deveria ser um gênero obrigatório no estudo do italiano LE, com a premissa de que não se estuda apenas língua, mas também cultura, nas aulas de línguas estrangeiras.

\subsection{DE GÊNERO DOMINANTE A GÊNERO SELETO ${ }^{28}$}

A ópera não requer erudição. Qualquer pessoa é capaz de entender e apreciar um espetáculo operístico porque, ao contrário do que se imagina, a ópera não é exclusiva, e muito menos excludente. Embora ela represente uma forma artística complexa, é imensamente popular e, por isso, não deve intimidar. Para entender melhor como o gênero se constituiu como tal, é preciso conhecer o público para o qual os espetáculos eram destinados, já que grande parte das transformações estéticas ocorridas ao longo dos séculos foi determinada exatamente pelo público.

A ópera se formou, a princípio, como um gênero elitista, idealizado pelos intelectuais da Camerata Fiorentina e encomendado para o exclusivo deleite das cortes, dos principados, dos padres e da nobreza em geral.

Pouco a pouco, essa realidade se transformou de tal maneira que todas as classes sociais puderam se beneficiar da ópera, democraticamente. Por dois séculos e meio, o espetáculo operístico foi o mais popular dos espetáculos públicos. Entretanto, o modo de ver o espetáculo mudou de acordo com a época em que foram encenados.

\footnotetext{
${ }^{28}$ Para uma leitura detalhada sobre a História da Ópera, leiam-se os volumes de Lauro Machado Coelho citados neste trabalho. Para quem prefere obter todas as informações importantes concentradas em um único volume, leia-se O Livro Completo da Ópera, de Gustave Kobbé, publicado em português em 1997. E para quem busca as principais informações, mas prefere seguir um roteiro enxuto, leia-se A Ópera, de Fernando Fraga e Blas Matamoro, de 2001. A partir deste tópico, até o fim deste capítulo, lê-se um resumo dessas obras, sobretudo da primeira e da terceira, em que tentei, imparcialmente, colher as informações mais objetivas e incontestáveis prestadas por seus autores.
} 
Para o público vezeniano do século XVII, os espetáculos não passavam de um produto de consumo rapidamente descartável, tanto que a maioria se perdeu, pois os manuscritos nem sequer eram publicados. As pessoas não tinham o hábito de assistir à ópera em silêncio e só paravam de conversar quando alguma coisa - uma bela ária ou um impressionante efeito de maquinaria - acontecia no palco e lhes chamava a atenção. Os camarotes transformavam-se em animados salões de ceia ou, às vezes, de encontros galantes. Enquanto isso, na sala, os vendedores de refrescos e doces circulavam anunciando o seu produto.

No século seguinte, cresce a presença de um público burguês de aficionados e virtuoses, que se caracterizará por buscar o aplauso e o dinheiro por meio do aperfeiçoamento das habilidades técnicas dos cantores.

No século XIX, a ópera vira sinônimo de cartão postal. Todas as grandes cidades da época têm dois monumentos característicos: a estação ferroviária e o teatro lírico. O teatro é o lugar fechado onde toda a cidade se exibe, dividida em classes sociais, conforme os andares. Lá, salvo a Igreja, estão todos: o governo, a aristocracia, a burguesia, a classe média e os pobres aficionados. Lá, tramam-se alianças políticas, planejam-se casamentos de conveniência, urdem-se fusões bancárias, tecem-se amores apaixonados e encontros clandestinos. Todos mostram seus sinais de prestígio: trajes, uniformes, joias e nomes destacados pela fama.

A partir de Wagner, porém, iniciou-se um retrocesso no que se refere à popularidade da ópera, dado o interesse de muitos artistas - influenciados pela crescente filosofia da música - na experimentação do gênero. Desde então, a ópera vem criando um público muito especializado, transformando-se, em certo sentido, em arte para artistas.

Contribui para uma nova elitização do gênero a revolução do cinema, que, no século XX, viria a se transformar na nova "arte total", encantando o público mundial com suas novas técnicas de atuação e encenação.

A princípio, a sétima arte se valeu muito da ópera para se legitimar, dado que os primeiros longas-metragens acabaram sendo uma espécie de ópera sem som. Paralelamente, o cinema tentou, desde seus princípios, filmar óperas, recorrendo ao som sincronizado por meio de discos ou à interpretação vocal e orquestral ao vivo. Já em 1903, registra-se um Faust, seguido de outras adaptações, com vozes reduzidas ou só parcialmente dotadas de som. Entretanto, as coisas mudaram quando se inventou o cinema sonoro, época em que nasceu a musical comedy cinematográfica norte-americana, também muito difundida pela França e 
Alemanha. Filha caçula da ópera, esse novo gênero estava predestinado a uma presença prolongada, que chegaria até os nossos dias.

É curioso notar que, quando se fala em ópera lírica, pensa-se logo na arte de Rossini, Verdi ou Puccini, e não em uma arte em contínua evolução. É como se a ópera tivesse fícado parada no tempo, junto com os "maníacos" do gênero, que não aceitam a renovação do modelo da época de ouro da ópera. Entretanto,

[a] ópera não é só para especialistas, nem tampouco para nostálgicos. A ópera, ainda que a maior parte do repertório tenha sido escrita em séculos anteriores, é um gênero atual, que se incorpora a toda a mídia audiovisual de nossos dias (FRAGA; MATAMORO, 2001, p. 5).

Ironicamente, ouvimos falar em "popularização da ópera" quando, na década de 90, os tenores Plácido Domingo, José Carreras e Luciano Pavarotti eclodiram nos palcos de todo o mundo entoando árias e outras canções de grande sucesso. O resultado foi a maior venda de todos os tempos de um álbum de música clássica (o Carrera-Domingo-Pavarotti: os Três Tenores em Concerto), segundo o Livro Guinness dos Recordes.

De fato, por muitos anos, diversos preconceitos rotularam a ópera "coisa de gente velha ou apanágio da alta sociedade", mas, segundo Sergio Casoy, isso é coisa do passado (CASOY, 2006).

Hoje, podemos contar com inúmeras iniciativas em favor da (re)popularização da ópera lírica, como a revitalização dos teatros, o apoio financeiro na produção dos espetáculos, o próprio cinema - que exibe filmes de ópera ou sobre ópera -, os inúmeros sites sobre ópera na internet e os espetáculos em formato DVD.

Além disso, melodramas de todas as épocas continuam a ser revisitados nos principais teatros de ópera de todo o mundo e, além da presença dos saudosos e aficionados do gênero, é cada vez mais expressivo o número de curiosos e interessados em conhecer o predecessor do cinema, seus grandes nomes e suas grandes produções. 


\subsection{PANORAMA HISTÓRICO DA ÓPERA}

Como se sabe, a ópera não ficou restrita à Itália. Suas sementes foram cultivadas também em outras terras, dando frutos de diferentes gostos e maduração. Portanto, para colhermos o seu significado mais justo e exato, devemos chegar não só à raiz do gênero, como também percorrer toda a plantação, demonstrando, ainda que de maneira concisa, toda a ramificação e as principais primaveras desta flor chamada ópera.

Embora não seja possível mencionar todos os grandes autores e compositores, bem como todas as grandes produções dos quatro séculos de vida da ópera lírica, passaremos em revista todas as reformas e contrarreformas que, de um modo ou de outro, contribuíram para a conceptualização do gênero.

\subsubsection{Antecedentes e nascimento}

Em verdade, se quisermos chegar à raiz do gênero operístico, não devemos ir até a Itália, mas até a Grécia. Pelo que se sabe, as tragédias gregas eram cantadas, possuíam coros e os atores usavam máscaras que lhes serviam de amplificador de voz. De fato, Vicenzo Galilei (1520-1591), pai de Galileo, antecipa a criação da ópera baseando-se no teatro musical dos gregos perdido pelos romanos ${ }^{29}$.

Entretanto, outras formas de expressão também remontam às origens da ópera, como as músicas litúrgicas, o teatro medieval, o teatro renascentista, o balletto, a favola pastorale e a comédia madrigalesca.

Mas foi em 1597 que o poeta Ottavio Rinuccini (1562-1621) e o compositor Jacopo Peri (1561-1633) compõem Dafne, considerada a primeira ópera nos moldes de hoje, apesar de ser rudimentar em termos de narrativa dramática. Infelizmente, sua partitura se perdeu.

\footnotetext{
${ }^{29}$ Vicenzo Galilei era membro da Camerata Fiorentina e autor do texto "Dialogo della Musica Antica e della Moderna, escrito em 1581".
} 
No entanto, quem, de fato, realiza o ideal da Camerata Fiorentina é Claudio Monteverdi (1567-1643) que, com seu Orfeu (1607), libera a palavra da música, de modo que o ator pode expressar com liberdade os sentimentos do personagem. Aqui, a música não é apenas um adorno, nem a palavra é apenas a recitação de um poema com a ajuda de algumas notas musicais. Destarte, pode-se considerar que a cena da descida de Orfeu ao inferno, Possente Spirto, no Ato III, é a primeira situação autenticamente dramática na história da música.

De Orfeu até L'Incoronazione di Poppea (1643), a ópera evoluiu consideravelmente. Em primeiro lugar, a última produção de Monteverdi não narra um mito, como se fazia até então, mas conta um drama histórico. Aliás, a história de Nero, Otávia e Popeia é uma alusão indireta a um episódio que fora fonte de escândalo e incontáveis mexericos em toda a Itália: de 1617 a 1627, Vincenzo II Gonzaga tentara, sem sucesso, divorciar-se de sua mulher, Isabella di Novellana, alegando não saber que, ao lhe ser prometida em casamento, ela já tinha 40 anos e não podia mais ter filhos (Nero, na ópera, também invoca a esterilidade de Otávia como motivo para repudiá-la).

Além do ousado libreto, que termina com o primeiro dueto de amor da história da ópera, Monteverdi inovou bastante na música, como atesta a criação do stile concitato, o tipo agitado e eloquente de acompanhamento que teria enorme importância nas obras teatrais posteriores e que foi a culminação de várias experiências que ele vinha fazendo com o ritmo. Tudo isso lhe conferiu um imenso sucesso, principalmente por parte do grande público, a ponto de influenciar muitas gerações de compositores. 


\subsubsection{A ópera barroca}

A partir de Monteverdi, a ópera se popularizou em dimensões inimagináveis. Os teatros, agora com capacidade para centenas, e até mais de mil espectadores, recebia um público de pagantes que, de uma forma ou de outra, começava a deliberar o sucesso ou o insucesso dos espetáculos. E as óperas começavam a ser encomendadas também pelos empresários, além dos príncipes, dos nobres e dos padres.

A consequência foi o afastamento do gênero da doutrina da Camerata Fiorentina, o que implicou na sua "decadência cultural", a despeito do seu crescente sucesso, motivado também pelo fato de que a ópera havia se tornado a principal ocasião de encontros mundanos.

De fato, enquanto os preceitos da Camerata apontavam para a união entre a música, a literatura e o teatro, o público tiranizava a produção em massa dos versos sobre a música já composta, o que dificultava - ou tornava praticamente impossível - o processo de dramatização do espetáculo.

Nem mesmo a opera seria, que nasceu das reformas no libreto propostas a partir de 1690 pelos poetas árcades romanos Silvio Stampiglia (1664-1725), Apostolo Zeno (16681750) e, principalmente, Metastasio (1698-1782), visando a domar os excessos da Escola Veneziana $^{30}$, foi capaz de conter a 'indústria' do espetáculo.

Não foi por acaso que Carlo Goldoni (1707-1793) declarou na sua própria autobiografia ter cometido o assassinato literário de Griselda, em 1735. Juntamente com seu cúmplice Vivaldi, ele "acomodou" e "emporcalhou" 31 o drama que Apostolo Zeno havia escrito 34 anos antes para Antonio Pollarolo. Entretanto, não demonstra qualquer embaraço em expor o fato. Réu confesso, Goldoni justifica, em tom divertido, ter operado cortes e ter adaptado os versos conforme a necessidade do compositor ou os caprichos dos virtuosos ${ }^{32}$.

\footnotetext{
${ }^{30}$ A Escola veneziana abarca as obras dos compositores que atuaram em Veneza entre os anos de 1550 e 1610. Ela foi responsável pelo desenvolvimento da ópera lírica na passagem do Renascentismo ao Barroco, em virtude da sua importância política e religiosa da época.

${ }^{31}$ Goldoni usa a expressão "accomodare o impasticciare", que pode ser lida no prefácio ao XIII volume das Commedie, editada em Veneza por G. B. Pasquali (1959, p. 721), in Tutte le opere.

${ }^{32}$ Cf. MURESU, 1982.
} 
Por isso, alguns autores da opera buffa $a^{33}$, na admirável tentativa de reabilitar o gênero, ironizaram a situação de servilismo da poesia em relação à música. Exemplo disso é o ato único de Giambattista Casti, significativamente intitulado Prima la musica e poi le parole (1786).

$\begin{array}{ll}\text { Maestro: } & \text { Voi, Signori poeti, siete matti. } \\ & \text { Amico, persuadetevi, chi mai } \\ & \text { credete che dar voglia attenzione } \\ & \text { alle vostre parole? } \\ & \text { Musica in oggi, musica ci vuole. }\end{array}$

Poeta: $\quad$ Ma pure questa musica conviene

ch'esprima il sentimento, o male, o bene.

Maestro: $\quad$ La mia musica ha questo d'eccellente, che può adattarsi a tutto egregiamente ${ }^{34}$.

Para demonstrar a força do virtuosismo na ópera, basta dizer que o Barroco rendeu um grande legado, utilizado até fins do séc. XIX, que foi o bel canto. O bel canto é um estilo de canto, aplicado à temática das óperas, que se traduz pelo refinamento e intensidade da expressão melódica, ou seja, a melodia é tão bela e intensa que ela entra na memória com facilidade. Esse recurso nasceu junto com uma ópera menos dramática e mais lírica, e é atribuída a Alessandro Scarlatti (1659-1725). Daí a expressão "música lírica” para designar canto ou mesmo a própria ópera.

Entretanto, no barroco, a exacerbação do desempenho vocal importava mais do que o próprio enredo, de modo que o libretista se via obrigado a rechear a ópera de momentos clímax sem uma devida preparação. A consequência era uma pompa vazia, uma propagação de textos complicados com uma sequência mal conectada de episódios. Além disso, um único

\footnotetext{
${ }^{33}$ Ópera-bufa (italiano: opera buffa) é o termo usado para descrever a versão italiana da ópera-cômica. Em sua origem estava ligada a desenvolvimentos musicais e literários que ocorriam em Nápoles na primeira metade do século XVIII, de onde sua popularidade se espalhou para Roma e o norte da Itália.

34 "Maestro: Os senhores poetas estão loucos / Amigo, persuada-se, quem os senhores acham que vai querer dar atenção às suas palavras?

Poeta: Mas esta música também deve exprimir, mal ou bem, o sentimento.

Maestro: A minha música o possui em excelência, / pois pode se adaptar a tudo magnificamente" (trad. minha) apud MUSERU, 1982, p.99.
} 
libreto podia ser musicado por dez, vinte ou mais compositores, sucessivamente e das maneiras mais diferentes, o que evidenciava a falta de dramaticidade da música em relação ao texto. De fato, a ópera precisava ser "purificada".

\subsubsection{O classicismo e a reforma da ópera}

Já no Barroco Tardio, período que compreende toda a primeira metade do século XVIII, encontramos alguns renovadores do dramma per musica, como Niccoló Jommelli (1714-1774), cuja obra surge como uma das tentativas mais consistentes de conciliar a expressividade natural do texto com as possibilidades virtuosísticas da música, e Tommaso Traetta (1727-1779), que reaproveita temas já tratados por Rameau e Lully ${ }^{35}$ - cujos ideais iluministas eram latentes - e traz ingredientes novos, sobretudo de origem francesa, para a ópera italiana.

Um pouco mais tarde, também em sintonia com os preceitos da ópera francesa, Christoph Willibald Gluck (1714-1787) aparece como o grande reformador da ópera-séria ${ }^{36}$. Em seu Orfeo ed Euridice (1762), Gluck e Ranieri de’ Calzabigi (1714-1795) introduzem, na ópera italiana, muitos elementos de origem francesa, como o coro mais numeroso, as cenas que rompem com a estrutura recitativo-ária, quadros de estrutura mais contínua, sinfonias descritivas e entradas de balé integradas à ação.

A intenção era transferir a força da gravidade da música para a poesia, fundindo verso, gesto e música numa unidade indivisível. Gluck, no seu prefácio à Paride ed Elena (1770), teria dito que "a canção, na ópera, nada mais é do que um substituto para a declamação no teatro"(COELHO, 2003, p. 29).

$\mathrm{O}$ afastamento do modelo metastasiano rumo a outro que combinasse as características mediterrâneas com as do teatro lírico francês fez as preferências temáticas tenderem de novo para os assuntos mitológicos, em detrimento dos episódios históricos, que tinham sido o ponto forte da ópera-séria.

Do ponto de vista literário, a concentração no tema mitológico fez com que o lado psicológico do personagem fosse mais bem desenvolvido, pois havia a convicção de que o

\footnotetext{
35 Jean-Philippe Rameau (1682-1764) e Jean-Baptiste Lully (1632-1687), este último, italiano naturalizado francês, foram dois grandes operistas franceses da época barroca.

${ }^{36}$ Gluck se inspira em Winckelmann para criar o seu ideal de "nobre simplicidade", em que a beleza é atingida quando as características particulares e individuais são subordinadas ao plano geral da obra.
} 
drama deveria refletir não as paixões fugazes do momento, ou os affetti ${ }^{37}$ particulares de um determinado indivíduo, mas as linhas mestras formadoras do caráter humano, o que podia ser conseguido por meio dos arquétipos.

Entretanto, a renovação do teatro lírico esbarrava-se na oposição ferrenha dos conservadores e, portanto, na maioria das cidades italianas, a ópera-séria continuava em voga - e continuaria até o final do século. Os libretos de Metastasio continuaram a ser musicados por muito tempo, mas, de 1770 em diante, cada vez que voltavam à cena, sofriam remanejamentos para a inserção de elementos progressistas, correspondentes a um gosto novo que vinha se firmando. Na ópera italiana estava acontecendo algo semelhante ao que Mozart, na época da Clemenza di Tito (1791), teria chamado de "revisar o libreto de Metastasio para transformá-lo numa ópera de verdade" (COELHO, 2003, p. 33).

Sem dúvida, os dois grandes nomes da ópera no período clássico foram Wolfgang Amadeus Mozart (1756-1791) e Gioachino Rossini (1792-1868) ${ }^{38}$. Cada um incorporou a renovação do gênero na sua obra de maneira distinta, tanto no campo literário, quanto no campo da música.

Em Mozart, verificamos a evolução psicológica do personagem aliada a uma completa expressividade dramática da música. Sua maior façanha foi delinear os caracteres dos personagens a partir de linhas vocais muito diversas. Assim, em Così Fan Tutte (1789-90), por exemplo, embora se trate de duas sopranos, a personagem Fiordiligi, impetuosa e apaixonada, contrasta sua voz com a voz ligeira e ondulante de Dorabella. Além disso, Mozart fundou a ópera nacional alemã, com peças meio cantadas e meio declamadas, batizadas Singspiel $^{39}$, em língua materna, ainda que também tenha se valido também do latim e do italiano.

Rossini, ao contrário, não se preocupou muito com o sincretismo entre a música e a poesia, haja vista o seu hábito de transferir trechos de uma ópera para outra, sem levar em conta as mudanças de sentido ocorridas quando esses transplantes eram efetuados. Sua importância como operista deve-se mais ao encantamento e à sedução de sua obra, que o

\footnotetext{
${ }^{37}$ A Doutrina das Afeições (Affektenlehre) é uma teoria estética barroca, exposta nos escritos de Werkmeister, Marpurg e Meister (embora o termo tenha sido cunhado pela musicologia alemã no início do século XX), que definia as emoções como uma série de afetos específicos (tristeza, alegria, ódio, amor), estabelecendo o princípio de que apenas uma delas poderia ser expressa dentro de uma unidade musical determinada, fosse ela uma ária, um movimento de peça instrumental ou qualquer outro tipo de número.

${ }^{38}$ Apesar de muitos críticos considerarem Rossini um compositor romântico, pelo fato de suas temáticas, e principalmente a sua música, serem genuinamente ligadas ao período, esteticamente suas óperas ainda conservam muitos elementos clássicos. Daí a sua inclusão também nesta subseção".

${ }^{39}$ Essa forma operística, bem como sua contribuição dentro da História da Ópera, será revista no tópico 2.3.2, em que trataremos da linguagem literária na ópera lírica.
} 
coloca como um pré-romântico. Além disso, suas óperas cômicas são altamente irônicas, o que o afasta do típico bufonesco clássico e o coloca entre os maiores compositores românticos italianos.

\subsubsection{A ópera romântica}

Deveras, para muitos críticos de ópera, a obra de Rossini concerne mais ao Romantismo que ao Classicismo. Isso porque a principal característica do artista romântico é o nacionalismo, exacerbado tanto na música de alguns autores quanto no texto de outros. De fato, o objetivo da música de Rossini é simplesmente "incitativo", é o fazer, com a sensualidade e a vitalidade de seus contornos, um apelo à sensibilidade do ouvinte, levando-o a compartilhar as emoções - sejam elas quais forem - do personagem. Desse modo, com as óperas-sérias do período napolitano, Rossini contribuiu de forma considerável para sintonizar a sensibilidade italiana num estado de espírito pré-risorgimentale $e^{40}$. Entretanto, sua música envolvente apenas emoldura o retrato das máscaras sociais e dos disparates convencionais do século XVIII, e a poesia ainda está em segundo plano.

Apesar de seu gosto por textos barrocos, Rossini buscou inspiração também na literatura - outro elemento importante do Romantismo -, como no caso de Otello, ossia il Moro di Venezia (1816), inspirado em Shakespeare e La Donna del Lago (1819), de Walter Scott. Entretanto, para muitos, trata-se de sacrifícios literários em prol de uma música excelente, o que o afasta definitivamente de Verdi ou Wagner, que souberam exacerbar seu nacionalismo a partir do sincretismo entre a música e a literatura.

De fato, o século romântico é o século do imperialismo, do patriotismo, do nacionalismo e do socialismo, percebidos também pela emoção que a obra é capaz de transmitir, de modo que a ópera servirá tanto para apoiar o patriotismo polaco, checo ou húngaro, como para provocar o alvoroço dos insurrectos italianos, ou para cantar o triunfo da raça germânica.

A essa altura, a ópera já era considerada o mais popular dos espetáculos mediterrâneos, de penetração, junto ao público de todas as camadas sociais, só comparável à do cinema e da novela de televisão nos nossos dias. Por isso, nenhum outro gênero foi mais

\footnotetext{
${ }^{40} \mathrm{O}$ espírito pré-risorgimentale refere-se à fase de preparação dos italianos para integrarem o movimento do Risorgimento ("ressurreição" em italiano), ou seja, o movimento de unificação da Itália ocorrido entre os anos 1815 e 1870 .
} 
eficiente do que a ópera na utilização da arte como instrumento social, podendo derrubar as barreiras entre os intelectuais e o público em geral.

Assim, é justo afirmar que a ópera desempenha papel de capital importância no processo de formação da consciência nacional de vários países, pois espelha de forma muito eloquente as aspirações e os ideais do povo e, mais do que isso, a sua consciência de pertencer a uma mesma comunidade.

É nesse sentido que a música do compositor romântico, grave e apaixonada, possui um indiscutível poder de persuasão, ainda mais quando acompanhada de um texto de conotação revolucionária. Era, portanto, à eloquência da ópera que se recorria quando se desejava marcar um fato relevante, como em ocasião da cerimônia que comemorou a libertação da Sicília dos Bourbons napolitanos, em 1848. De fato, a benção da bandeira tricolor foi acompanhada pelos empolgantes acordes do "Guerra, guerra" da Norma, de Vincenzo Bellini (1801-1835), e o Comitê que assumira o controle do poder avançou pela nave da igreja precedido de uma banda que tocava o dueto dos Puritani.

Em geral, os libretistas passaram a não se interessar mais por temas mitológicos ou legendários - embora a escola nacional alemã tenha preferido esses gêneros, como veremos no próximo tópico - tendo que driblar a Censura para levar aos palcos obras literárias contemporâneas consumidas febrilmente pelo público leitor, como Os Noivos, de Alessandro Manzoni, ou $O$ Werther, ópera baseada em O Sofrimento do Jovem Werther, de Goethe.

Mas o principal alvo dos censores eram as produções de cunho histórico. Nesse caso, os autores tinham que apelar para a troca dos nomes das personagens e ambientar a ópera em locais distantes e inócuos para a representação em determinados teatros. Quem adivinharia, hoje, que Orietta di Lesbo era a Joana d'Arc da ópera de Verdi? E que por trás de Rudolfo di Stirling escondia-se o Guilherme Tell de Rossini?

As mudanças estéticas vieram apenas a partir da obra de Bellini, já que antes de 1820 era necessário lisonjear os cantores e respeitar as convenienze da tradição. No Romantismo, a ópera torna-se o veículo para a circulação de ideias e exige-se dos cantores que se curvem a uma concepção geral definida pelo libretista e pelo compositor. E não eram raras as influências exercidas por chefes revolucionários, como Giuseppe Mazzini, por exemplo. Desse modo, temos enfatizadas as dimensões religiosas e nacionalistas do tema da ópera, sob um enfoque nitidamente democrático e, até mesmo, populista.

Aliás, foi o próprio Mazzini quem teria diagnosticado a ópera de seu tempo uma “enumeração de suas partes - uma enfiada de cavatinas, coros, duetos, trios e finales, 
interrompidos (em vez de serem unificados) por recitativos envelhecidos, aos quais ninguém mais presta atenção: um mosaico, uma galeria, um acúmulo, com frequencia um choque de ideias divergentes, independentes e desligadas umas das outras, e que ficam girando em torno de si mesmas, como espíritos aprisionados em um círculo mágico" (COELHO, 2002, p. 42).

De fato, o grande herói da estética romântica operística foi, sem dúvida, Giuseppe Verdi (1813-1901). Em sua maturidade, ele devolveu à ópera sua unidade dramática, articulando a complexidade da estrutura melódica ao tratamento profundo do argumento. $\mathrm{Na}$ sua trilogia romântica, composta por Rigoletto (1851), La Traviata (1853) e Il Trovatore (1853), a música preanuncia o tema já na abertura, e narra, junto com o texto, as aventuras de seus personagens plenamente humanos e complexos, com direito a todos os temas recorrentes no Romantismo, como o amor impossível, o sacrifício pelo amor, a sublimação da morte e a redenção.

\subsubsection{Wagner e o drama musical}

A comparação entre Giuseppe Verdi e Richard Wagner (1813-1883) é inevitável. Nascidos exatamente no mesmo ano, os maiores representantes do gênero até hoje revelados percorreram caminhos muito diferentes, e cada um levou, a seu modo, a ópera até suas últimas consequências. De fato, ambos intuíram - se bem que de forma totalmente diversa determinados procedimentos dramáticos e de escrita musical, e modificaram radicalmente a estrutura tradicional da "ópera de números" 41 , abrindo ao drama lírico caminhos inteiramente novos.

Enquanto Verdi enfeixa as mais típicas características da produção musical de seu povo pela predominância do canto, da melodia generosa, da expressão direta e apaixonada das emoções, em Wagner, a música instrumental atinge autossuficiência e assume a função de verdadeira narradora da história.

Wagner formula princípios teóricos, como a ideia do drama musical como "obra de arte total" (Gesamtkunstwerk), o modo de estruturação do ato como estrutura contínua (durchkomposition), a teoria da melodia infinita (unendliche melodie), e pratica o que ele

\footnotetext{
${ }^{41} \mathrm{O}$ termo "ópera de números" será abordado na subseção 2.3.1.
} 
mesmo chamou música do futuro (zukunftsmusik). Suas propostas são genuinamente progressistas e revolucionárias, e reivindicam o renascimento da tragédia grega.

Entretanto, à diferença de Gluck, que parte do texto como elemento racional do drama, Wagner subordina a poesia à música, e esta resgata a base musical da palavra. De fato, ele considera a linguagem falada como fundada na música (o canto, o pranto, o riso e o grito são anteriores à palavra articulada), e a língua nacional como única realidade da linguagem. Para ele, não existe uma língua universal e a poesia é intraduzível, de modo que a sua música se constrói sobre as sugestões da língua poética alemã.

Wagner imaginava seu drama como um discurso contínuo e, portanto, prescindiu da ária, dos duos, dos conjuntos e dos demais números fechados da ópera tradicional para narrálo. Em lugar das pausas e das intermitências estão os motivos condutores (leitmotiv), que narram uma ação encarnada pelos personagens. O motivo condutor seria uma espécie de signo privilegiado da fatalidade, ou do que hoje chamamos inconsciente, uma força movida pelo desejo e que nos leva a expressarmo-nos de determinada maneira.

Para ilustrá-lo, tomemos como exemplo a tetralogia do Anel dos Nibelungos (18691874): O deus Wotan imagina construir uma espada invencível, para derrotar o dragão que ficou com o seu tesouro. Não o diz, porém a orquestra faz soar o motivo condutor da espada. Logo, a espada aparece cravada no tronco de uma árvore que sustém uma cabana, num bosque. A orquestra retoma o motivo, de maneira sonolenta: é uma espada inerte. Na caverna, onde o jovem Siegfried aprende a forjar o aço, jazem os fragmentos dessa espada, criados pela orquestra com o motivo da espada, desta vez fragmentado. Depois de reconstruída a espada, o motivo é tocado com um ar triunfante. O mesmo ocorrerá quando Siegfried quebrar a lança de Wotan, (ignorando que se trata de seu avô). O motivo da espada é pura música e, no entanto, adquire significação literal e dramática conforme o momento do drama em que soa, levando a ação de um ponto a outro (daí o nome de condutor).

Wagner prefere os temas místicos, talvez porque sua música seja mística, já que se forma a partir de uma melodia que se transforma e parece não se resolver nunca, a ponto de pôr em risco o sistema das tonalidades e os modos clássicos. De fato, ele abre o campo para as experiências politonais e atonais posteriores. Além disso, sua música está em funda comunhão com algumas palavras cheias de sons e de combinações já por si próprias muito musicais, de caráter transcendental. Não é à toa que Nietzsche (1872) vê na obra wagneriana a recuperação da religiosidade do deus Dionísio por meio da música e da dança, que conduzem o homem a um saber superior, derivado do transe visionário, e não do intelecto. 
Tecnicamente, Wagner perseguiu o sincretismo total entre as artes, redigindo todos os seus libretos, preparando seus cantores, vigiando as encenações e sugerindo os cenários. Em busca da "arte total", o compositor-poeta-diretor Richard Wagner foi, sem dúvida, um "artista total".

\subsubsection{O Verismo}

A suntuosa produção de Aida (1870), de Giuseppe Verdi, encerra o período romântico italiano e dá início a um período de transição, denominado Pós-Romantismo. Trata-se de uma época marcada por indecisões, idas e vindas, acertos e erros em busca de um caminho novo. $\mathrm{O}$ progressivo desmoronamento dos valores sobre os quais se edificara o Risorgimento, aliado ao natural desgaste do estilo de vida e de cultura do Romantismo, já em declínio, gera um período crítico de incertezas, insegurança, desejo de renovação, e busca ansiosa por novos caminhos. Entre 1860 e 1890, o Pós-Romantismo italiano passará por uma fase de buscas, por meio, inclusive, da aceitação reticente de influências estrangeiras, de que a ópera, como gênero musical peninsular por excelência, mostrará os mais claros reflexos.

A maior de todas as influências será Carmem (1875), de Georges Bizet (1838-1875), ópera que desperta a atenção dos compositores e da crítica para as possibilidades novas do

Realismo. É interessante notar que, apesar de Carmem surgir como inovação temática no mundo operístico, La Traviata (1853) é, inegavelmente, sua grande precursora. Ambas abordam um assunto contemporâneo de natureza escandalosa. Na ópera verdiana, porém, temos a morte redentora (e romântica) de Violetta Valèry, enquanto o personagem de Bizet não se regenera, e morre assassinada.

Aliás, é o desenlace violento que marca o cânon verista: o assassinato de Nedda nos Pagliacci (1892); o esfaqueamento de Scarpia e a tortura e o fuzilamento de Cavaradossi, na Tosca (1900); o suicídio na Madama Buterfly (1904), na Iris (1898) ou na Martyre (1911), de Samaras; o assassinato de Luigi no Tabarro (1918); o envenenamento em Adriana Lecouvreur (1902).

Dispostos a retratar a vida real, os veristas reagiram ao mundo lendário e mitológico de Wagner, bem como aos excessos do wagnerismo. Os estudos mais recentes demonstram que eles não só ampliaram a gama temática, trazendo para o palco da ópera de tema sério personagens, situações e um tipo de linguagem que, antes, estavam restritos apenas ao 
domínio bufo, como também forçaram uma renovação na escrita vocal e na técnica de acompanhamento orquestral.

Houve, nessa fase, uma campanha para a renovação do libreto e do estilo de canto, remontando ao Verdi maduro e à sua defesa da parola scenica, a declamação melódica bem próxima da fala.

A primeira obra considerada verista foi Cavalleria Rusticana (1890), de Pietro Mascagni (1863-1945), extraída da novela homônima de Giovanni Verga. Aqui, ainda temos a estrutura da ópera de números, mas são introduzidas mudanças que acenam para uma nova fase e caracterizam sua linguagem como verista, como as frases breves, entrecortadas, baseadas na expressão coloquial; o uso do canto falado, da imprecação, do grito e da fala nos momentos de maior tensão dramática, como que indicando que esses extremos emocionais não podem se manifestar por meio do canto, mas sim apelando para a voz natural do intérprete. Entretanto, algumas particularidades contradizem o que podemos chamar de verismo puro, como o uso do coro, por exemplo, que exerce apenas uma função decorativa na ópera (como na maioria das produções dessa época), e o uso da própria língua italiana, ao invés do dialeto siciliano.

Entretanto, outras tendências conturbaram o mundo artístico até o início do século XX, como o Simbolismo e o Decadentismo, fazendo com que se retornasse a atitudes tipicamente românticas, revitalizadas, contudo, pela passagem através dos filtros realistas, o chamado Neo-Romantismo. Essa fase eclética pode ser ilustrada, sobretudo, pela obra de Giacomo Puccini (1858-1924), em que, por uma questão de sensibilidade natural, realismo e sentimentalismo sempre estiveram misturados de forma muito pessoal.

\subsubsection{A ópera no século XX}

Como já anunciava o ecletismo do fim do século anterior, a ópera do século XX vai reunir diversas tendências, a ponto de caminhar para a desconstrução do gênero, como acontece em Porgy and Bess (1935), considerada uma das grandes óperas modernas. De fato, George Gershwin (1898-1937) utilizou uma veia melódica riquíssima, motivos do folclore negro e sua experiência como autor de comédias musicais, traçando um quadro vivíssimo, sensual e patético da vida dos negros em um lugar marginal de Charleston (Carolina do Sul). 
O canto apela para todos os recursos, desde o grande desenvolvimento melódico ao coro do spiritual, os finais grandiosos da comédia musical, o jazz, a recitação abrupta de forte impressão verista, e até a voz falada, tudo isso informado por um enérgico uso dos ritmos dançantes.

Mas quem pode sintetizar a evolução da ópera em todo o século e, em especial, no mundo germânico, é Richard Strauss (1864-1949), tanto pelo volume quanto pela variedade estética de sua obra. Tanto seus poemas sinfônicos, como suas canções, sejam com acompanhamento de piano, ou de orquestra, são concebidos dramaticamente e sempre evocam a cena e a narração teatrais. Sua obra mais interessante é Capriccio (1942), uma espécie de diálogo posto em música, com texto de Clemens Krauss (1853-1954), que trata de um conjunto de artistas que se propõe a criar uma ópera num salão típico do século XVIII, discutindo o eterno tema da primazia da música ou das palavras.

No início do século, desenvolve-se em Viena a escola que ganha o nome dessa cidade, e que se baseia na doutrina de Arnold Schönberg (1874-1951), conhecida como música serial dodecafônica. No lugar das escalas de sete sons da gama, esse tipo de composição remonta à música wagneriana e aniquila a noção de tonalidade. Os sons se organizam em séries, e a falta de resolução produz uma sensação de constante tensão e ansiedade. Essa técnica é de difícil aplicação na ópera e, embora tenha sido utilizada parcialmente por outros compositores, normalmente não é serial, e, por isso, ficou conhecida como atonalismo livre.

Aqui as artes se misturam e se (con)fundem à maneira do expressionismo de Wozzeck (1925), de Alban Berg (1885-1935), em que a paranoia do marido que, em uma crise de ciúmes, mata a própria mulher pode ser sentida na atonalidade da música, bem como no seu texto parco, fragmentado e aberto. Do mesmo modo, as artes se misturam e se (con)fundem à maneira do impressionismo de Igor Stravinsky (1882-1971), um dos músicos decisivos de nossa época, que opera um gênero misto em que se fundem elementos de ópera, recitação, balé e pantomima.

Estamos diante de uma situação totalmente nova no mundo da ópera, em que se verifica a contribuição e, mais do que isso, uma simbiose entre os diversos gêneros musicais, ora cantados, ora recitados, ora falados. A linguagem é eclética, aberta às mais versáteis sugestões vanguardistas. Muitos músicos não se mostraram preconceituosos em relação às fronteiras entre o erudito e o popular, pois as formas do musical de estilo americano atraemnos tanto quanto a música antiga. Mesmo a música do passado ganha, agora, contornos muito 
livres, deliberadamente "inautênticos", se comparadas às músicas de compositores medievais ou renascentistas.

Os temas também são elementos inovadores na arte contemporânea, e chegam a beirar o absurdo, como na "anticomédia" A Cantora Careca (1986), de Luciano Chailly (19202002), baseada no texto de Eugène Ionesco (1909-1994). A trama foi inspirada nos diálogos do manual Berlitz para se aprender inglês. Nesse manual, aparecia um casal que, embora aparentemente casado há muito tempo, dizem-se coisas que já deveriam saber: como se chamavam, onde moravam, quantos filhos tinham, etc. Esse é o teor dos diálogos absurdos das personagens, inicialmente musicada dentro dos princípios tonais e que vai, aos poucos, descarrilando, e por meio de efeitos harmônicos estranhos e inesperados, acentua a perda do contato com todas as formas codificadas de comunicação, até a dissolução completa da chamada normalidade.

Conclui-se que a evolução da ópera é a evolução da própria arte, a qual reflete, indubitavelmente, a evolução do ser humano. Seria impossível passar por todas as fases dessa evolução dando o devido crédito a todos os compositores e libretistas memoráveis, quanto mais a todas as obras memoráveis. De fato, respeitando a concisão que este capítulo exige, tentei acenar sempre para o novo, para uma efetiva contribuição na concepção do gênero. Lamento o fato de Puccini ter sido apenas nomeado. Lamento mais ainda não ter podido mencionar grandes nomes como Leoncavallo ou Debussy, assim como não mencionei meu compatriota Carlos Gomes. Destarte, relego essa aprazível tarefa aos professores que, certamente, encontrarão nos infinitos títulos de ópera os mais diversos assuntos e/ou temas de interesse a serem tratados em sala de aula.

\subsection{A LINGUAGEM DA ÓPERA}

Como síntese de várias outras artes, a ópera faz uso das linguagens da música, da literatura e do teatro para narrar uma história. Em suas origens, essa arte foi criada, justamente, para sincretizar as demais, de modo que se pudesse alcançar o ideal perdido da tragédia grega.

Entretanto, ao longo de toda a sua história, músicos e libretistas se dividiram entre a primazia da música sobre o texto e vice-versa, sacrificando, em inúmeros casos, uma dessas 
linguagens. E a linguagem teatral, por sua vez, sempre dependeu da superação desse conflito para se legitimar.

De fato, desde os seus primórdios, é possível extrair uma considerável lista de obras irretocáveis literária e musicalmente, em que se verifica a perfeita fusão do libreto e da música. É o caso de Monteverdi e Busenello, Gluck e Calzabigi, Mozart e da Ponte, Verdi e Boito, Strauss e Hofmannsthal, Stravinski e Auden, em que texto e melodia parecem realmente ter brotado um do outro. O sucesso teatral, enfim, é consequência invariável dessa fusão dramática.

Martin Cooper teria dito que "não existem dois países ou épocas que se tenham posto de acordo sobre a função relativa que a música, a literatura ou o elemento espetacular deveriam desempenhar idealmente dentro do dramma per musica para que se pudessem obter resultados orgânicos", o que nos permite concluir que cada país, cada época e, mais do que isso, cada autor, atribuiu tais funções a seu bel prazer (COELHO, 2002).

Portanto, ao escolher uma ópera, o professor deve estar ciente dos limites literários, musicais ou teatrais daquela obra, para que a sua metodologia não se oponha à essência do objeto. Ao contrário, espera-se que a metodologia tenda para o estudo da(s) linguagem(s) que aquela ópera se propôs a privilegiar.

Assim, ao escolher uma ópera verista, sua metodologia tenderá para uma abordagem comunicativa; ao escolher uma ópera nacionalista de Verdi, a metodologia tenderá para uma abordagem social-histórica, e, ao escolher uma ópera romântica, expressionista ou wagneriana, a metodologia tenderá para uma abordagem humanístico-afetiva. Obviamente, não se espera a adoção de uma única abordagem, pois, como já tivemos ocasião de estudar, vários movimentos confluem em duas ou mais tendências estéticas, assim como o ensinoaprendizagem de línguas estrangeiras moderno pauta-se na confluência de várias linhas metodológicas.

Vejamos, agora, como essas linguagens evoluíram desde a origem do melodrama até os nossos dias.

\subsubsection{A música}


Essencialmente, o que diferencia a ópera das outras formas de representação que incluíam a música até o fim do século XVI é a falta de unidade narrativa, a falta de unidade musical ou o estilo polifônico muito cerrado - inadequado para a expressão teatral - dos intermédios, da favola pastorale e das comédias madrigalescas, respectivamente.

Esses três elementos puderam ser contemplados no novo dramma per musica por causa do recitativo monódico, que adere estreitamente à narração do texto. Aqui, o fim da melodia coincide com o fim do verso, e só em alguns momentos seletos o canto tem um colorido mais expressivo. Entretanto, esse estilo, conhecido como stile rappresentativo ou monodico, tornava a declamação um tanto tediosa aos ouvidos do público, pois se valia de uma só nota para cada sílaba do texto.

Por isso, em momentos de maior tensão dramática, alguns compositores recorreram à ornamentação, como é o caso de Marco da Gagliano (1582-1643). No prefácio à sua Dafne, o compositor deixa claro que os ornamentos não devem dar a impressão de terem sido superpostos à linha melódica, mas de "terem nascido da monódia como uma expressão natural dos sentimentos". Aos poucos, a ornamentação vai evoluir para a alternância recitativo/ária, problematizando a fusão entre a literatura e a música na ópera.

De fato, enquanto o recitativo tem de ser dramaticamente expressivo, a função da ária é ser musicalmente expressiva. O recitativo responsabiliza-se pela ação, e a ária, pela exaltação dos sentimentos. O que sempre se discutiu no melodrama é o modo de estruturá-lo logicamente sem sacrificar sua unidade dramática ou musical. A princípio, imaginava-se algo extremamente uniforme, em que as partes solistas (árias) quase não se distinguiam dentro do fluxo do recitativo. À medida que o melodrama evoluía, porém, as árias passaram a ter estruturas bem precisas, até o ponto de poderem se destacar completamente do melodrama e constituírem "unidades autônomas".

O aperfeiçoamento das formas musicais da ária contribuiu para que o seu número fosse cada vez maior no melodrama, a ponto de superar o número de recitativos em muitos autores do Barroco. Além disso, dada a atrativa de suas melodias, os músicos passaram a repeti-la para que o público a ouvisse mais uma vez. Surgiu, assim, a forma da ária ternária, também chamada aria da capo, em que a terceira seção retoma a primeira e a repete com ornamentações improvisadas pelo cantor. No início do século XVIII, a estilização crescente fez com que se desenvolvessem numerosos estereótipos, ou seja, árias destinadas a situações bem determinadas como amor, ódio, juramento de vingança, celebração de vitória, etc., com procedimentos estilísticos próprios e localização mais ou menos rígida dentro do espetáculo. 
O recitativo monódico, por sua vez, evoluiu para o recitativo seco (com acompanhamento apenas do cravo), que pode ser definido como um discurso semimusical, muito ágil, de extensão melódica reduzida, com acentos marcados, pontuação irregular como da fala, e muitas notas repetitivas sustentadas por um número pequeno de acordes. E a partir da ópera-séria, o recitativo também pode ser mais lírico, acompanhado por instrumentos como as cordas ${ }^{42}$, por exemplo, o qual recebe o nome de recitativo acompanhado.

Além dessas formas de composição bastante distintas, temos o arioso, que ocupa lugar intermediário entre o recitativo e a ária; os números de conjuntos, ou seja, os duetos, os tercetos, os quartetos; e o coro. Desde a abertura até a última cena do último ato, as óperas contam com muitos ingredientes orquestrais e vocais cujas principais funções são maravilhar o público e narrar a história.

Grosso modo, podemos dizer que a Escola veneziana e a ópera-séria metastasiana valorizaram muito as árias e as formas fechadas, a ponto de danificar a estrutura da ópera. Foi a época dos pasticci $^{43}$ e das árias de baú ${ }^{44}$, em que a verossimilhança e a unidade dramática já não importavam tanto quanto a beleza dos ornamentos e o virtuosismo dos cantores.

No período clássico, os autores ainda trabalhavam com a "ópera de números" 45 , mas outra vertente, encabeçada por Gluck, pretendeu eliminar as longas árias sentenciosas ou baseadas em metáforas prolongadas e desbastar os recitativos secos ou convertê-los em recitativos acompanhados, mais dinâmicos, para tentar dar mais fluidez, continuidade e organicidade musical aos dramas.

Portanto, ao mesmo tempo em que grandes autores tentaram conter as extravagâncias do belcantismo, o estilo declamatório aprimorou-se ao longo dos séculos, desde o stile concitato monteverdiano, passando pelo recitativo acompanhado clássico-romântico, o arioso permanente wagneriano e a parola scenica verdiana, até desaguar no sprechgesang ${ }^{46}$ contemporâneo.

\footnotetext{
42 "As cordas, em uma orquestra, são os violinos, as violas, os violoncelos e os contrabaixos."

${ }^{43}$ Forma de composição coletiva, muito popular no século XVIII, da qual participavam vários compositores; designa também colagens feitas a partir de uma determinada ópera com a inserção de trechos recolhidos na obra de vários autores.

${ }^{44}$ Peça muito comum durante o Barroco, que reunia todos os ornamentos que um cantor sabia fazer melhor; ele a carregava consigo, "dentro do baú", para onde fosse, e sempre dava um jeito de incluí-la nas óperas que fosse cantar.

${ }^{45}$ Estrutura típica da opera seria barroca, formada por uma sequência de árias da capo fechadas, separadas por recitativos secos; dá-se esse nome porque cada uma das árias vinha numerada na partitura. De modo geral, designa-se assim a estrutura fragmentária que predomina nos séculos XVII-XVIII, antes de a reforma gluckiana preocupar-se em dar ao drama lírico maior continuidade.

${ }^{46}$ Termo usado por Schönberg e Berg para designar o tipo de declamação em que a altura das notas é indicada, mas a voz flutua entre o recitativo tradicional e a palavra falada.
} 
Pode-se dizer que, enfim, cada época, e mais especificamente cada autor, obteve a sua singularidade por estruturar, a seu modo, as partes cantadas e as partes recitadas da ópera. De fato, o estilo do autor, bem como a época na qual está inserido, deve ser levado em consideração para uma efetiva análise musical e literária da obra. Isso fica bem claro quando estudamos obras de mesmo título representadas na mesma época ou em épocas diferentes, como é o caso do mito de Orfeu, musicado por 64 autores (segundo registro no Oxford Dictionary of Opera), desde Jacopo Peri até Harrison Birtwistle, em 1986.

Com efeito, cada autor trabalhou diversamente o tema. Alguns souberam explorar o fato de Orfeu ser cantor e poeta tanto na música quanto na poesia da ópera, como é o caso de Monteverdi, por exemplo. Outros ficaram mais presos à trama do marido que vai ao inferno buscar sua amada, como é o caso de Antonio Sartorio, entre outros.

Portanto, ao se levar o mito de Orfeu em classe, é importante que o professor saiba se o coro, por exemplo, é decorativo ou possui função dramática dentro da obra, assim como deve ficar claro o motivo pelo qual determinado autor escolheu um recitativo, e não uma ária, para narrar, por exemplo, a parte em que a mensageira vem dizer a Orfeu que Eurídice foi picada por uma serpente e morreu.

Para além da música instrumental, é muito interessante instigar os alunos na percepção das vozes $^{47}$ e suas funções dramáticas. Continuando esse exemplo, seria interessante discutir em classe por que, na ópera de Peri, Orfeu é representado por um castrato $^{48}$, ao contrário de tantos outros autores, que preferiram dar-lhe a voz de tenor ou de barítono. Essas questões ficarão mais bem esclarecidas no capítulo que trata da didatização da ópera, em que discutiremos detalhadamente seus instrumentos de análise.

\subsubsection{A literatura}

O libreto de ópera é especial por reunir, em um só volume, as características do romance e da poesia. Com raras exceções, narra um drama em forma de versos - tal qual o

\footnotetext{
${ }^{47}$ As vozes na ópera recebem nomes em função das notas que podem alcançar. Para uma classificação simplificada, baixo, barítono e tenor são vozes masculinas e contralto, mezzo-soprano e soprano são vozes femininas que alcançam, respectivamente, notas mais graves, notas intermediárias e notas mais agudas.

${ }^{48}$ Soprano ou contralto masculino, cuja voz aguda foi artificialmente conservada pela remoção dos testículos antes da mudança da voz; prática iniciada pela Igreja Católica, em cujos corais não se admitiam a presença de mulheres e, a partir do século XVII, estendida ao teatro de ópera, onde eles se tornaram imensamente populares.
} 
poema épico -, sejam esses rimados, brancos ou livres, separados por estrofes ou contínuos, em italiano ou dialeto, com todas as figuras de linguagem e recursos literários a que se tem direito e, acima de tudo, musicalmente legitimado.

A propósito, é o poeta quem oferece ao compositor as estruturas adequadas a serem musicadas, convidativas ora dos recitativos, ora das árias, além de ser o responsável por criar os pretextos para a encenação.

A temática dos libretos sempre esteve em consonância, mutatis mutandis, com a temática literária. Temas mitológicos, históricos, romans à clef, personagens arquétipos, dramas psicológicos, enfim, tudo de que a literatura oral e escrita já tratou também foi tratado na ópera. A literatura escrita foi, inclusive, fonte inesgotável das óperas a partir do século XIX.

Entretanto, a literatura na ópera nunca foi autossuficiente, já que sempre precisou se conformar esteticamente à música. Basta dizer que a autoria das óperas vem atribuída apenas ao compositor, enquanto o libretista aparece como mero coadjuvante, como um colaborador. De fato, como tivemos oportunidade de estudar, as palavras estiveram em segundo plano em relação à melodia em muitas escolas operísticas e, por isso, o valor literário das óperas sempre foi questionável.

No Barroco, os atos fragmentavam-se em uma impressionante sequência de cenas curtas preocupadas apenas em acumular emoção em cima de emoção, suspense em cima de suspense, a ponto de prejudicar a verossimilhança da trama. Foi Metastasio, considerado por muitos iniciados o melhor libretista de todos os tempos, o grande reformador do libreto, pois pregou a eliminação de tudo o que fosse inútil na trama.

Mas, por sua própria natureza, a ópera sempre eleva as emoções em grau único, e se alimenta de momentos dramáticos muito intensos (e, por vezes, demasiado extensos), pois precisa desafogar na tensão dramática toda a sua música. Portanto, sob o prisma da tensão, podemos afirmar que a literatura operística construiu, ao longo da sua história, suas próprias regras, as quais estão muito arraigadas à forma musical que se convencionou praticar.

Assim, a separação recitativo/ária também indicava a separação relaxamento/tensão dramática, podendo a preparação para a tensão ser ilustrada por acompanhamentos orquestrais específicos. Com o fím da "ópera de números", os autores passaram a substituir a unidade básica do teatro metastasiano - recitativo/ária da capo - por quadros mais bem organizados, em que o foco dramático se desloca do recitativo para as diversas seções de música contínua. 
Desse modo, o drama se intensifica psicologicamente, e passa a refletir cada vez mais o caráter humano em lugar de refletir, simplesmente, os afetos particulares de um determinado indivíduo.

Paralelamente, temos a contribuição da opéra-comique e do Singspiel ${ }^{49}$ mozartiano, cujos diálogos falados impulsionaram a uma maior naturalidade e continuidade textual. Considerando que o texto falado dentro da ópera revela, pela primeira vez, certa autonomia literária, não podemos deixar de atribuir a essas formas fundamental importância para o aprimoramento da literatura na ópera a partir do Romantismo.

\subsubsection{Léxico, Figuras de Linguagem e Morfossintaxe}

Como todo gênero que utiliza a língua para fins estéticos, o libreto de ópera também recorre a ornamentos lexicais e morfossintáticos, além de fazer alto uso de figuras de linguagem. Obviamente, o êxito poético do libreto depende, acima de tudo, da qualidade do poeta e do seu grau de integração com as ideias do compositor.

$\mathrm{Na}$ Itália, o toscano tornou-se a base do italiano moderno porque no século XIV os escritores Dante, Petrarca e Boccaccio elegeram-no para redigir os monumentos a Divina Comédia, as Rimas e o Decameron, respectivamente, formando o alicerce da língua literária peninsular. Com o passar do tempo, porém, a língua poética foi se tornando cada vez mais distante da própria prosa culta, assumindo contornos alatinados, sobrecarregando-se com construções metafóricas e perifrásticas que a tornavam profundamente artificial. "Sinos nunca eram sinos", escreve Budden ${ }^{50}$ (1973), "mas bronzi sacri; e a meia-noite era sempre l'ora della morte" (apud COELHO, 2002, p.47).

A propósito dos clichês, Migliorini (1983, p.601) cita um curioso texto do poeta Cesare Cantu, que, por volta de 1820, fazia a um jovem aspirante a escritor recomendações que, hoje, seria impossível de se tratar com seriedade:

\footnotetext{
49 Tipo de drama musical alemão em que - da mesma forma que no opéra-comique francês, de que sofre influência - os números cantados, tocados ou dançados são interligados por diálogo falado.

${ }^{50}$ BUDDEN, J. "Verdi and the World of the Primo Ottocento" e "The Collapse of a Tradition (Italian Opera 1840-1870)" nos volumes I e II de The Opera of Verdi. Londres: Cassell, s/d.
} 
Em poesia, quanto mais te distanciares do discurso da plebe, melhor. Há a escolha das palavras, para começar: nunca diga abbrucia, afflige, cava, innalza, è lecito, spada, la patria, la morte, la poesia, mas adduge, ange, elice, estolle, lice, brando, la terra natia, il fato, la musa. [...] E deves abominar, meu filho, todas as ideias banais que nos tragam à mente coisas demasiado corriqueiras. Em lugar dos substantivos, utiliza circunlocuções elegantes; nunca dirás amore e, sim, bendato arciero; em vez de vino, liquor di Bacco; e em vez de aquila ou leone, regina de' volanti e biondo imperator della foresta.

De um modo geral, essa era a linguagem do melodrama até meados do Romantismo, considerada a quintessência da linguagem teatral elevada.

Em contraposição a todo rebuscamento da linguagem poética do melodrama, temos a linguagem da comédia, que assume as formas mais variadas e imprevisíveis, não só no que se refere ao uso do dialeto, da gíria ou do falar infantil, mas também do italiano estropiado falado por estrangeiros, ou, até mesmo, de diálogos escritos em francês para refletir um hábito pedante da sociedade aristocrática.

A partir do Romantismo, os autores partem em busca de um estilo novo - já que a ópera torna-se o veículo para a circulação de ideias - mais autêntico, verdadeiro e natural, que culminará na linguagem verista, com a recuperação da cultura dialetal e uma drástica revisão no estilo e na linguagem de seus textos. Passa a ser frequente o uso de formas coloquiais, de um diálogo desenvolto, como no formidável trecho do início da Bohème, em que o pintor Marcelo comenta: "Rodolfo, io voglio dirti un mio pensier profondo: ho un freddo cane!" e o jovem poeta responde, no mesmo tom: "Ed io, Marcello, non ti nascondo che non credo al sudor della fronte." 51

\subsubsection{Fonologia}

Quando o arioso contínuo proposto pela Camerata dissociou-se em recitativo e ária nitidamente diferenciados, o recitativo acomodou-se a fórmulas melódicas e harmônicas restritas, enquanto as árias se ampliaram, ganhando melodia com cantabile expansivo, o que a

\footnotetext{
51 "Rodolfo, quero te dizer um pensamento profundo: estou sentindo um frio do cão!", "E eu, Marcelo, não te escondo que já não acredito no suor da testa.” (Trad. minha).
} 
tornou mais brilhante e, ao mesmo tempo, mais artificial. A coloratura ${ }^{52}$, cavalo-de-batalha dos cantores e objeto do fascínio das plateias, também se desenvolveu, a ponto de muitas vezes passar o texto para uma posição secundária. Era difícil compreendê-lo com todas as repetições de membros de frase, alargamento e compressão, ou espichamento de sílabas e efeitos decorativos superpostos às palavras.

De fato, uma ária nunca seria a mesma de uma récita para a outra, pois a versatilidade dos intérpretes saberia confiar a cada uma delas feição permanentemente cambiante. Apesar disso, muitas técnicas vocais foram sistematizadas e praticadas por escolas inteiras; algumas resistiram à época e vigoram até hoje. Nicola Porpora (1686-1768), por exemplo, sistematiza o uso da messa di voce - a técnica que consiste em atacar uma nota pianissimo, levá-la gradualmente até um fortissimo e, depois, num efeito de smorzando, deixá-la recair até o piano e atacar, sem tomar fôlego, a frase seguinte. Até hoje, esse é um efeito que provoca arrepios nos espectadores.

Além da impostação lírica, que dificulta a compreensão exata das palavras, existem as várias modalidades de emissão de voz típicas do canto lírico, como o dó de peito ${ }^{53}$, o falsete ${ }^{54}$ ou o whistle register ${ }^{55}$, que exaltam as qualidades canoras dos interpretes, dão mais beleza e graça ao canto e, eventualmente, são requeridas em situações especiais, como, por exemplo, na ária "Io son di sir John Falstaff", em que o personagem Falstaff canta em falsete para imitar a voz de Alice Ford.

Quanto ao texto, é muito comum encontrar na ópera figuras de linguagem fonéticas, como a aférese, que consiste na supressão da vogal ou sílaba do início da palavra (Lo 'ntelletto; Padron 'Ntoni) ou a apócope, que consiste na supressão da vogal ou da sílaba do fim da palavra (cittade/città; bello/bel; frate Giuseppe/fra Giuseppe).

Por tudo isso, é possível afirmar que o canto lírico não é o mais adequado para exercitar a compreensão oral do ouvinte, o qual precisará ler o libreto para entender o que os personagens estão, de fato, dizendo. Mas, por outro lado, a maior característica fonológica da língua italiana é a sua vocalidade, a qual pode ser muito bem ilustrada por meio do canto lírico. A maior prova disso é que o virtuosismo nunca abandonou a ópera mediterrânea, nem

\footnotetext{
${ }^{52}$ Ornamentação elaborada de uma melodia vocal; também chamada de fioritura ou canto figurato.

${ }^{53}$ Dó agudo colocado uma oitava acima do dó central, cantado pelo tenor com voz plena.

${ }^{54}$ Técnica vocal por meio da qual o cantor emite, de modo controlado (não natural, e por isso "falso"), sons mais agudos que os da sua faixa de frequência acústica natural (tessitura).

${ }_{55}$ Chamado também de registro de apito e registro assoviado, o whistle register é o registro mais agudo da voz humana.
} 
mesmo nas obras maduras de Verdi. De fato, o italiano convida ao alongamento das vogais, tanto daquelas localizadas no fim das palavras como daquelas que precedem uma consoante dupla. Imaginem, agora, um alemão virtuose? Portanto, desde que bem trabalhado, o canto lírico pode ajudar na pronúncia da língua italiana.

Além disso, a dificuldade de compreensão não acomete todas as formas operísticas. A ópera cômica é um perfeito exemplo de ópera inteligível, já que o caráter das cenas cômicas exigia, naturalmente, o desenvolvimento de um estilo silábico de composição que garantisse a compreensão do texto - o que o torna automaticamente mais realista, pois despido de ornamentações estilizadas. É fato, portanto, que os autores das comédias se preocuparam com a clareza da enunciação das palavras, já que o efeito engraçado depende, a maior parte do tempo, de se entender o que está sendo dito.

\subsubsection{O teatro}

Na História da Ópera, a mise en scène sempre reuniu todos os ingredientes de "efeitos espetaculares" adequados ao gosto do público e à estética teatral. Entre os ingredientes principais temos o coro, o balé e a produção do cenário. Certamente, o teatro não deve ser estudado como um componente à parte, destacado das influências da música e da literatura na ópera. Ao contrário, o papel das outras artes é, exatamente, criar situações que evoquem a utilização dos elementos de que uma representação cênica pode dispor.

O gosto barroco sempre apelou para grandes cenas de efeito, como aparições de deuses, cenas de combate, tempestades, naufrágios, etc., e, por isso, a maioria dos espetáculos daquela época denota certa opulência. O Orfeu de Luigi Rossi (1597-1673), por exemplo, que estreou em 2 de março de 1647 em Paris, precisou de duzentos homens para montar o cenário, além de recrutar grande parte dos músicos em Roma. De fato, nessa versão do mito grego temos "uma miscelânea de sequências sérias e cômicas, entremeadas de pretextos para bailados e cenas com efeitos de maquinaria, bem ao gosto do público parisiense" (COELHO, 2000, p. 67).

A propósito, é na França que surge, no século XIX, o estilo Grand-Opéra, caracterizado pelo gosto das montagens suntuosas com muitos efeitos espetaculosos. De acordo com essa escola, os espetáculos tinham cinco atos, tema histórico que permitisse a 
reconstituição de época e de ambientes luxuosos e variados, com muitas mudanças de cenários e intrigas em que se multiplicassem os cortejos, grandes festas, cenas de tempestade ou outros fenômenos naturais. Além disso, dava-se grande importância à criação de cor local, e as sequências de balé eram obrigatórias.

A partir de Gluck, porém, quando os autores tentaram conferir às árias uma função nova, essencialmente teatral e em desfavor do belcantismo, a produção também sofreu consideráveis mudanças. De fato, com a evolução do gênero, os autores passaram a valorizar uma forma de elaboração cênica mais concisa e articulada, ao mesmo tempo em que crescia o interesse em se criar personagens marcantes de densidade puramente teatral. As grandes obras operísticas não exigirão apenas bela voz ou cenários magníficos, mas, sobretudo, presença de palco e eminente senso dramático. Haja vista o famoso episódio do Macbeth, para o qual Verdi recusara Eugenia Tadolini, pois a voz dela era "bonita demais", mostrando que a beleza de timbre e o virtuosismo da execução estavam cedendo lugar à expressividade e à compreensão teatral do papel.

Nada impede, porém, que cenários suntuosos tenham abrigado óperas de forte conteúdo dramático, como é o caso da Aida, de Giuseppe Verdi. De fato, a montagem da ópera mais encenada nos grandes teatros de todo o mundo comporta nada menos do que sete cenas diferentes em seus quatro atos - entre estátuas gigantescas e inúmeras referências ao mundo egípcio, além de exigir um elenco de grandes vozes em todos os seis solistas principais.

Ao contrário, nas comédias ocorre, desde cedo, um fenômeno no contrafluxo do que se passa com o drama: canto e encenação se aproximam e assimilam características mútuas, ao inverso do estilo elevado, em que a representação era estática, formal e de grande artificialismo.

Outras variações de ordem estritamente teatrais referem-se à estrutura da obra. Enquanto o Barroco apresentou óperas muito longas, às vezes intermináveis, de até cinco atos e mais os intermezzi $i^{56}$ cômicos, as óperas do século XIX apresentam, em média, três atos - à exceção de Wagner, que pregava a representação de um único ato como forma de forjar a unidade dramática - das quais muitas são compostas de $s c e n e^{57}$. No século XX, ainda teremos

\footnotetext{
${ }^{56}$ Diz-se do hábito de apresentar pequenas cenas cômicas no intervalo entre um ato e outro da ópera de tema sério.

${ }^{57}$ A scena (no singular) designa o esquema ternário de construção da cena que se desenvolve na ópera do século XIX: consiste de um recitativo acompanhado introdutório; uma ária (um cantabile) em que determinado problema é exposto; uma ponte (o tempo di mezzo) que pode ser um novo recitativo, um diálogo ou um pequeno trecho coral; e uma cabaletta (uma ária que contrasta com o cantabile anterior por ser mais curta e de ritmo
} 
obras de três atos organizados em cenas que, apesar de não obedecerem mais a um esquema único, continuam oferecendo mais continuidade ao ato.

A despeito de tudo o que foi dito sobre o valor da representação cênica na ópera, é justo questionar as diversas montagens dos dramas de outras épocas, já que o espectador de hoje só pode experimentar visualmente o espetáculo a partir das adaptações modernas. No Kobbé: o Livro Completo da Ópera, ao comentar a diversidade das versões existentes de $A$ Coroação de Popeia (1642), de Monteverdi, o conde de Harewood escreve:

Acesos debates [em torno desses trabalhos] recomeçam toda vez que aparece uma nova edição ou uma anterior é retomada. De minha parte, inclino-me a pensar que as adaptações ainda consideradas válidas dez ou quinze anos depois de produzidas são tão raras que podem ser encaradas como verdadeiras recriações de gênio. O trabalho de reconstituição deve conciliar, em qualquer época, as exigências da erudição (desde questões de linguagem musical até uma meticulosa recriação das condições originais de produção) e a necessidade de comunicação com o público. O adaptador não pode esquecer que um compositor do século XVIII ignorava as práticas do século XIX; mas sabe também que as plateias do século XX estão condicionadas pela gradação e culminância dramático-musical das óperas de Verdi e Wagner e desconhecem o som produzido pelos castrati, esperando que o herói tenha os atributos de virilidade, e não os de um soprano em papel masculino. Se a erudição levar a melhor sobre a eficácia, a nova versão será uma falsificação estéril dos efeitos pretendidos pelo compositor; se a atualização e a verossimilhança cênica e musical sufocarem a autenticidade, os puristas protestarão. Mas o certo é que, sem essas adaptações, sem as convicções próprias e o senso de imediatismo de seus editores, o público sequer tomaria conhecimento dessas obras "históricas" - e só teria a perder.

Portanto, caberá ao professor selecionar a montagem que mais se aproxima dos seus objetivos, sejam estes estéticos ou de conteúdo dramático. O importante é que ele esteja ciente das atualizações e/ou adaptações da ópera escolhida, de modo que elas sirvam para explicar uma determinada visão interpretativa do drama e não influenciem univocamente na análise da música ou do libreto.

usualmente mais acelerado), em que a resolução do problema é proclamada; a scena, com sua estrutura de recitativo, ária, tempo di mezzo e cabaletta, dotada de relações temáticas e tonais estreitas, funcionou como um elemento essencial para conferir maior continuidade à escrita do ato, que passou a ser formado por grandes blocos de canto ininterrupto. 


\section{A APRESENTAÇÃO DA ÓPERA NAS AULAS DE LÍNGUA ESTRANGEIRA}

\subsection{A ÓPERA COMO MATERIAL AUTÊNTICO}

A ópera lírica será apresentada ao aluno em sua forma original, integral e sem qualquer adaptação morfossintática. Podemos dizer que abordaremos o gênero como um 'material autêntico', de acordo com a seguinte definição:

Por material autêntico entende-se todo aquele material que não foi adaptado, simplificado ou criado para ser ministrado a alunos de línguas (BERWALD, 1986). Muito pelo contrário, é um material que foi escrito ou gravado para um público comum e não especificamente para alunos (KIENBAUM et al., 1986) e reflecte um contexto situacional e cultural próprio (ROGERS; MEDLEY, 1988). (apud CARVALHO, 1993, p. 118) ${ }^{58}$.

Mas antes de discorrer sobre as suas efetivas vantagens, é necessário aprofundar melhor esse conceito, entendido e aplicado sob diferentes prismas nas aulas de língua estrangeira. Para tanto, não será abordada a tradicional dicotomia material autêntico e material não-autêntico ${ }^{59}$, porque não nos interessa aqui comparar qualitativamente os materiais autênticos, quais sejam artigos de jornal, revistas, poemas, contos, propagandas, embalagens, cardápios de restaurantes, catálogos, filmes, canções, etc. aos diálogos ou textos artificiais dos manuais de língua estrangeira. Ao contrário, interessa-nos comparar qualitativamente um 'material autêntico adaptado' a um 'material autêntico não-adaptado'.

Mas o que se entende por adaptar um 'material autêntico'?

De fato, para evitar a exposição do aluno a "um estilo menos familiar" (CONFORTI; CUSIMANO, 2005), os manuais de italiano LE preferem apresentar os textos escritos adaptados. Praticamente, todos os seus artigos de jornal, propagandas, anúncios, receitas culinárias e outros gêneros textuais passam por uma adequação morfossintática e de tamanho,

\footnotetext{
${ }^{58}$ BERWARD, J. P. Au courant: Teaching French Vocabulary and Culture Using the Mass Media. Language in Education: Theory and Practice 65, Centre for Applied Linguistcs, Washington, D.C. 1986; KIENBAUN, B.; RUSSEL, A. J.; WELTY, S. Communicative Competence in Foreign Language Learning with Authentic Materials. Final Project Report. ERIC reproduction document, ED. 275 200, 1986; ROGERS, C.; MADLEY, F. Language with a Purpose: Using Authentic Materials in the Foreign Language Classroom, Foreign Language Annals, 21, 5, 467-468, 1988.

${ }^{59}$ Cf. FRANZONI, 1992.
} 
o que equivale dizer que são reduzidos, simplificados e modificados. No que concerne à literatura, ao contrário do tratamento dispensado a outros gêneros, é muito comum que os manuais utilizem trechos de obras literárias autênticos, livres de qualquer adaptação morfossintática. Mas será que o simples fato de apresentarem 'trechos', e não a obra completa, não significaria editar e, talvez por isso mesmo, adaptar?

A propósito, podemos questionar, também, o conceito de recorte como fruto de uma escolha do autor do material didático, que preferiu um trecho a outro como uma implicação direta da sua metodologia. Na grande maioria dos casos, o recorte atende a objetivos de ordem gramaticais, em que a totalidade de sentido da obra não é requerida para desenvolver as atividades propostas.

Os livros paradidáticos, ${ }^{60}$ por sua vez, há muito funcionam como "uma ferramenta auxiliar no processo de ensino e aprendizagem de língua estrangeira" que se adéquam "à competência textual do aprendiz" e, ao mesmo tempo, "veiculam o discurso literário"61. A consequência de se adaptar o texto literário dessa maneira "é que, num movimento contrário ao da ênfase na literatura, o aspecto mais especificamente literário (estético, múltiplo, denso) do texto é sacrificado para que se alcance a compreensão do enredo, da mensagem, do referente, da denotação [...]" (SANTORO, 2007, p. 21).

Portanto, observa-se que o conceito de material autêntico, de acordo com a definição referida, isento de qualquer manipulação, raramente configura nos manuais de italiano LE. Ao contrário, observa-se que, desde que o texto seja “'acreditável', livre de artifícios forçosos que, para atender frequentemente a fins 'gramaticais' específicos, desnaturam totalmente a sua fidedignidade" (CONFORTI; CUSIMANO, 2005, p.7), sua adaptação é justificada e, até mesmo, legitimada. Ao mesmo tempo, no que concerne especificamente ao texto literário, são raras as abordagens que preveem a sua apresentação unitária, sem recortes. Portanto, a partir de agora, parece-me mais justo acrescentar à expressão material autêntico o adjetivo adaptado, ou não-adpatado, para um melhor entendimento do tipo de apresentação da ópera lírica que se fará neste trabalho: integral e 100\% autêntica.

Embora a proposta de submeter o aluno ao texto original e completo da ópera possa parecer audaz e temerária, visto que estamos diante de uma tipologia textual considerada

\footnotetext{
${ }^{60}$ Refiro-me aos livros de literatura adaptados para fins didáticos.

${ }^{61}$ SANTOS, A. C. dos; MENEZES, L. de S. C. de. O lugar e a vez da literatura paradidática nas aulas de E/LE. Disponível em: <http://www.filologia.org.br/viiicnlf/anais/caderno09-10.html>. Acesso em: 17 nov. 2008.
} 
difícil, é só uma questão de saber trabalhar o controlável e o fugidio nas aulas, dois elementos constitutivos do processo de ensino-aprendizagem de uma língua estrangeira. De fato, as reflexões de Patrizia Franzoni (1992) em Linguística Aplicada ao ensino-aprendizagem de línguas estrangeiras apontam para a possibilidade de lidar com a angústia do aprendiz por meio de alguns instrumentos de controle, acreditando que é no contato (e no conflito) com o outro, com o alheio e com o novo que se fundamenta o processo de aquisição do idioma.

Desse modo, acredito que os instrumentos de controle capazes de baixar o filtro afetivo $^{62}$ do aluno em contato com o material operístico apoiam-se, principalmente, na colaboração entre as diversas linguagens de que a ópera dispõe. Com efeito, como pudemos ver no segundo capítulo, o gênero operístico sincretiza as linguagens verbal, visual e sonora que, em 'conjunção', contribuem para a construção do sentido da ópera. Neste trabalho, essa colaboração mútua dar-se-á no plano dos sons, da imagem e das palavras, como podemos verificar a seguir.

\subsection{A COLABORAÇÃO ENTRE AS LINGUAGENS DA ÓPERA}

\subsubsection{Os sons}

"Onde cessa a palavra, começa a música."

Kierkegaard

Se a música se vale de uma linguagem exclusivamente sonora, é natural que encontre maior afinidade com a fala, para a qual o som é indispensável. Por vezes, custa-nos distinguir as fronteiras que as separam, como é o caso da própria língua italiana, considerada a língua "musical" por excelência. Para Paolo Balboni, isso não significa muito em termos técnicos, já que está relacionado ao fato de o italiano possuir mais vogais. Culturalmente, porém, é o Melodrama que pode explicar, em grande parte, tal estereótipo/prestígio, pois é

\footnotetext{
${ }^{62}$ A noção de filtro afetivo (KRASHEN, 1981) refere-se à influência de 'variáveis afetivas' como a motivação, a autoconfiança e a ansiedade na aquisição de uma segunda língua.
} 
considerado "a contribuição mais original da Itália para a Europa" ${ }^{63}$. Além disso, temos a metáfora de Gannon, para quem “a Itália é uma ópera lírica" ${ }^{64}$.

Pela forte representação da Itália, e também do italiano, na música (e na ópera), é muito comum conhecer pessoas que aprenderam a língua a partir do interesse pela música, como nos pode testemunhar Sergio Casoy (informação pessoal) ${ }^{65}$ :

\begin{abstract}
Apesar de não pertencer a uma família italiana, posso afirmar que o meu é um caso típico de osmose. Nascido e criado na década de 50 no bairro paulistano - então italianíssimo, com forte presença meridional - do Brás, os dialetos do sul eram o que mais se ouvia na rua, entre os moradores, comerciantes, açougueiros, sapateiros. A música italiana, tanto as cançonetas como as árias de ópera, faziam parte do nosso cotidiano. Nós, crianças e adultos, as ouvíamos no rádio, nas vitrolas de todas as casas, e, lógico, ao vivo executadas pelos frequentadores das cantinas e pizzarias que lá se reuniam para comer e cantar, e que eram em enorme número no bairro. Quando comecei a entender que a ópera era um teatro cantado, a necessidade de ler e entender bem os libretos passou a ser, para mim, fundamental. Assim, com pouco mais de vinte anos, fui estudar italiano como se deve, na escola do ICIB na rua Frei Caneca. O resto decorre de prática e exercício.
\end{abstract}

Do mesmo modo, também é muito comum conhecer pessoas que cantam muito bem em língua italiana, mesmo sem terem passado pelo estudo formal do idioma. O tenor Sergio Senger $^{66}$ é um grande exemplo do que digo, pois, apesar de não ter prosseguido o curso de língua, conta com um considerável repertório de canções italianas, inclusive de árias e canções dialetais.

Exemplos como o de Casoy e Senger, frequentes no mundo da música e nas salas de aula, ilustram como a motivação pela música pode repercutir no interesse, e até no efetivo (e afetivo) aprendizado, das línguas estrangeiras. E se o som da música é capaz de despertar a atenção para o som da fala, o contrário pode ser igualmente inerente, embora implícito, desde o início do percurso da sua aprendizagem.

\footnotetext{
${ }^{63}$ Reporto-me aos slides reunidos sob o título "L'italiano che canta", assinado por Paolo E. Balboni, disponível no endereço <http://www.consatene.esteri.it/NR/rdonlyres/EE01AD30-3107-467C-A3D497969A1A4E32/6600/BalboniLitalianocantato.ppt>, acessado em 22 nov 2008.

${ }^{64}$ Ibidem. Balboni refere-se a Gannon Martin J. em seu livro Global-Mente. Metafore culturali per capire 17 paesi, Milão: Baldini Castoldi Dalai, 2004.

${ }^{65}$ Trecho extraído de entrevista com o professor Sergio Casoy, da Escola de Comunicação e Artes (ECA) da Universidade de São Paulo (USP), realizada em 28 de agosto de 2008. Os grifos são meus.

${ }^{66}$ Sérgio foi meu aluno no primeiro nível dos cursos do Italiano no Campus, ministrados para a comunidade externa na Faculdade de Letras da Universidade de São Paulo, em 2006. Infelizmente, por conta das longas viagens para a Europa (Sérgio trabalha como tenor contratado por uma empresa de cruzeiros marítimos), ele teve de abandonar o curso, pelo qual sempre se mostrou muito interessado, embora enfrentasse problemas de aprendizado decorrentes da dislexia.
} 
Para identificar um signo verbal produzido pela fala, temos que reconhecer, antes de tudo, sua configuração fonêmica (PONZIO, 2001). É somente o som que importará, em um primeiro momento, para a clara identificação de um enunciado. Para compreendê-lo, entretanto, há que se considerar também o timbre, o tom, a altura da voz, a situação em que foi produzido, etc. Equivale dizer que o som é requerido sempre na interpretação da fala, tanto para distinguir entre dois enunciados como "que calor" e "que sabor", como para perceber, superada a primeira etapa de reconhecimento do signo, se "que calor" é interpretante de "abre a janela", "vamos sair?" ou, ainda, "hei, vamos conversar!".

Em contrapartida, na música, "um único som, por exemplo, com seu timbre, altura, intensidade e duração característicos, já é extremamente rico em informações ao ouvinte, quanto mais a combinação diversificada entre muitos deles" (FERREIRA, 2002, p. 14).

Grosso modo, visto que estamos tratando de estruturas muito complexas, podemos dizer que a música requer muito mais abstração do que a fala. Para um leigo, a música pode ser totalmente compreensível em termos de sensação, de emoção, enquanto a fala exige elementos mais lógicos e racionais. A música pode criar "uma dimensão mais profunda, sobretudo enquanto expressão de emoção e sentimentos, valendo-se de recursos poéticos inesgotáveis com seu potencial sugestivo, com o jogo de melodias e harmonias, o ritmo e os dinâmicos contrapontos, [...] e a palavra seria insuficiente diante da intensidade poética superior provocada pela interferência da música” (PEIXOTO, 1986, p. 32).

Quando sobrepostas, o resultado é que a linguagem da música prevalece, inclusive neurologicamente ${ }^{67}$. Isso pode ser observado no caso de Sérgio Senger, acima referido, que "canta" os sons da fala sem saber identificá-los e compreendê-los. Ou então, quando dançamos a melodia alegre de uma canção cuja letra é triste ${ }^{68}$.

Ao longo da história da ópera, a música desempenhou vários papéis em relação à palavra: "acompanhou" o canto em Monteverdi, foi articulada às árias e aos recitativos na chamada "ópera de números", foi soberana em Wagner, e adquiriu participação cênica concreta em Dessau (PEIXOTO, 1986, p. 37 e 38). O Romantismo não só revolucionou a função da música no teatro como foi decisivo para instaurar o processo de integração entre

\footnotetext{
${ }^{67}$ Balboni, "O italiano que canta", <http://www.consatene.esteri.it/NR/rdonlyres/EE01AD30-3107-467C-A3D497969A1A4E32/6600/BalboniLitalianocantato.ppt>, acessado em 22 nov 2008.

${ }^{68}$ A título de ilustração, cito a canção "Saudosa Maloca", na voz de Adoniran Barbosa.
} 
música, poesia e teatro. Balboni refere-se ao período romântico da ópera como a época em que "as palavras frequentemente tornam-se música, e não as entendemos". ${ }^{6}$

Ora, se nem mesmo os nativos são capazes de identificar e compreender os sons da fala inseridos na ópera, sobretudo no período romântico, seria descabido aplicá-lo como tarefa aos nossos alunos. Portanto, durante as audições da ópera, bastará que os alunos tenham consciência de que as duas linguagens combinaram e organizaram seus sons como uma maneira de exprimir-se e de interagir com o outro. Em um primeiro momento, o aluno deverá passar por um processo de abstração que lhe permitirá ser guiado apenas pela sonoridade, sem qualquer compromisso teórico com a música ou de identificação e compreensão da fala. O passo seguinte é aprofundar os detalhes e fazer com que ele se questione "por que é assim?”, “o que distingue uma sonoridade da outra?”, ultrapassando a emoção em busca da informação e reflexão ${ }^{70}$.

\subsubsection{A imagem}

"A música é teatro."

Patrice Chéreau

Até agora, vimos que a ópera será apresentada integralmente no original ao aluno, na tentativa de proporcionar um grau de emoção muito próximo ao que o nativo experimenta diante do objeto. É evidente que isso pode se tornar relativo quando especificamos o tipo de ouvinte/espectador de ópera a que nos referimos.

Os que apregoam a hegemonia da linguagem sonora imaginam "o teatro como simples materialização cênica de valores literários, como os que esquecem que a ópera não é escrita para ser gravada em discos ou tapes, nem para ser mutilada em forma de concertos [...]" (PEIXOTO, 1986, p. 24). Além disso, há também os que buscam o espetáculo como se fosse um monumento do passado, e veem na renovação cênica a subversão dos valores áureos e felizes que a tradição operística erigiu (PEIXOTO, 1986).

\footnotetext{
69 "Le parole spesso diventano musica... e non si capiscono". Balboni, "L'italiano che canta", http://www.consatene.esteri.it/NR/rdonlyres/EE01AD30-3107-467C-A3D497969A1A4E32/6600/BalboniLitalianocantato.ppt, acessado em 22/11/2008. Tradução minha. ${ }^{70}$ Ferreira (2002, p. 18) distingue o bom ouvinte em dois tipos: o descompromissado e o curioso.
} 
Felizmente, a parcela conservadora e tradicionalista do público de ópera é cada vez menos expressiva, o que tem permitido a renovação estética do teatro lírico, apostando-se na ideia de integração dos diferentes elementos que concorrem para a realização do espetáculo como forma de 1) alcançar a unidade estilística, a organicidade da ópera, a concretização do conceito de Gesamtkunstwerk (obra de arte total), que Wagner perseguiu tão obstinadamente; 2) assegurar a compreensão realista e crítica do drama e 3) questionar e explicar da melhor maneira a realidade sócio-cultural na qual o drama se insere, abrindo espaço, também, para a análise crítica da nossa sociedade, pela própria concepção que se tem de arte (PEIXOTO, 1986).

Também em termos didáticos, a encenação representa uma ferramenta indispensável na (re)constituição do objeto, fundamental para a sua compreensão. Já que as palavras, na ópera, surtem o mesmo efeito da música, são o cenário, os gestos e a expressividade dos atores que permitirão ao aluno unir texto e contexto, ainda que parcialmente. Ao mesmo tempo em que os sons levarão o aluno a um processo de abstração, a encenação o chamará para a realidade; teremos som e imagem complementando-se para conferir a emoção, para definir os temas, o caráter enunciativo e funcional das cenas, enfim, para (re)significarem-se mutuamente.

Entretanto, não podemos esquecer que a palavra teatro, em grego theátron, estabelece o lugar físico do espectador, "lugar onde se vê". De fato, "é o lugar onde acontece o drama frente aos espectadores, complemento real e imaginário que acontece no local de representação" ${ }^{, 11}$. Por isso, a apresentação da ópera por meio de um aparelho DVD talvez seja a melhor opção para trazer o teatro para dentro da sala de aula, de modo que caberá ao professor selecionar a versão mais adequada do espetáculo para esse fim. Ele terá que considerar, sobretudo, os aspectos relativos à encenação, os únicos passíveis de modificações rigorosas que concernem às questões de integração entre as linguagens de que já tratamos.

\footnotetext{
${ }^{71}$ Wikipédia. Enciclopédia virtual. Disponível em: <http://pt.wikipedia.org/wiki/Teatro>. Acesso em nov 2008.
} 


\subsubsection{O texto}

"Ópera em inglês faz tanto sentido quanto beisebol em italiano."

H. L. Mencken

Como um nativo é capaz de entender o melodrama se, como vimos, as palavras não são inteligíveis no plano sonoro? A resposta, simples e direta, remete-nos ao libreto, companheiro inseparável do espectador de ópera no teatro. Além de conter a transcrição do espetáculo a ser encenado, o libreto inclui didascália e, muitas vezes, prefácio e notas explicativas sobre a ópera.

Ao receber o libreto na porta do teatro, muitos espectadores se põem rapidamente a par da narrativa antes que o espetáculo inicie. Outros preferem conhecer a trama durante o espetáculo, e dividem sua atenção entre a visão cênica e o libreto. Fernando Peixoto (1986, p. 68) conta que, no caso de textos cheios de peripécias e complicações dramáticas, a encenação era feita mantendo a luz na plateia para que o público tivesse condição de seguir o libreto.

Em tempos mais modernos, muitos teatros (mas não o tradicional teatro de óperas Scala de Milão) adotam o sistema de legendagem na parte superior do palco, oferecendo ao público a oportunidade de acompanhar, em tempo real, as palavras cantadas, assim como a maioria dos DVDs de ópera. O teatro Metropolitan, em Nova York, inovou (e chocou), surpreendendo o público com monitores que exibem o letreiro nas poltronas!

Por outro lado, a questão de como o texto escrito se apresenta no espetáculo parece ir de encontro ao empenho de encenadores modernos, como Patrice Chéreau, cujo método de encenar uma ópera consiste em "sentir o texto em todas as suas dimensões, no esforço de contar visualmente a trama proposta" (PEIXOTO, 1986, p. 51, grifo meu).

Com efeito, enquanto muitos buscaram, e buscam, a unidade dramática da ópera, o libreto e a legenda aparecem como cisão, como um elemento perturbador que impede a integração das artes vocal, musical e cênica. Para Stanislavsky ${ }^{72}$ (apud PEIXOTO, 1986, p. 51),

\footnotetext{
${ }^{72}$ STANISLAVSKY, K. My life in Art, Moscou, Foreign Languages Publish House, s/d.
} 
[...] a música, de fato, é o conteúdo dramático de uma ópera, fornecido numa forma musical já acabada. É na música, e somente nela, que é preciso procurar a natureza da ação. A construção dramática de uma ópera contém o significado de todos os motivos criativos para a organização da linha lógica das ações do ator.

E não podemos esquecer que, entre os diversos tipos de espectadores, há também aqueles que não se importam absolutamente com a trama, porque apesar de serem capazes de ficar de olhos abertos, não enxergam nada. "Escolhem uma atitude de religiosa concentração numa suposta 'mensagem sagrada', que não seja conspurcada por imagens que possam perturbar uma espécie de insólita 'contemplação auditiva'” (PEIXOTO, 1986, p. 23).

Posto isso, o ideal não é desconsiderar o libreto em prol de uma encenação que dê conta de narrar a ópera pela música, quanto menos fechar os olhos para a imagem e para o texto escrito, mas ter a consciência de que o texto dá suporte ao contexto, esclarece-o, caracteriza-o estética e semanticamente. Sem o libreto, a ópera seria incompleta. A solução para todo esse impasse pode ser a leitura antecipada do texto escrito, disponível também na internet, de modo que a atenção do espectador esteja totalmente voltada ao espetáculo, sem que ele corra o risco de não entender a história narrada.

Para nós, será mais interessante, em um segundo momento ${ }^{73}$, sobrepor as palavras aos planos sonoro e imagético, de modo que possamos instaurar o sincretismo da ópera ao mesmo tempo em que mantemos o elemento surpresa - importante para a motivação do aluno - e, além disso, promovemos a compreensão mútua de todos os elementos criativos do gênero. Portanto, sem qualquer intenção de tornar a visão da ópera artificial, podemos dizer que a escolha de utilizar a legenda em italiano durante a segunda visão das cenas atende a mais uma exigência didática.

De fato, nesta fase, o aluno poderá unir a emoção da música à dialética da encenação e da legenda, vivenciando um processo de osmose, do qual se espera ativar a necessidade de uma melhor compreensão da trama. E posteriormente, para que possam fazer as atividades propostas para a compreensão e análise das cenas, os alunos deverão utilizar o libreto, que pode ser definido como outro instrumento de controle contra a angústia dos aprendizes.

\footnotetext{
${ }^{73}$ Digo segundo momento porque, antes de ver a cena com a legenda em italiano, sugiro a visão da cena sem legenda, para que o aluno possa apenas sentir os afetos propostos pela música e pela encenação.
} 


\subsection{AS ESTRATÉGIAS COGNITIVAS}

A apresentação da ópera sugerida neste projeto implica a mobilização de certas estratégias de aprendizagem ${ }^{74}$ por parte dos alunos para que possam compreender e interpretar as cenas seguindo sempre o mesmo percurso didático. Esse percurso, dividido em três fases, vai "da emoção à razão" e, à visão de cada cena, os alunos deverão perfazer as etapas relacionadas à percepção dos sons e da imagem, da intelecção dos sons e da imagem associados ao texto (legenda) e, finalmente, do texto escrito (libreto).

A primeira fase implica a mobilização de estratégias afetivas relacionadas à emoção da ópera. A segunda e a terceira fases implicam a utilização de estratégias cognitivas.

Além disso, após o contato individual com o material (primeiro com a visão da cena e depois com o libreto), os alunos compartilharão com outros alunos o que apreenderam da cena, de modo que possam praticar também as estratégias sociais ${ }^{75}$.

\subsubsection{Primeira fase: A "leitura" dos sons e da imagem}

De um modo geral, todos somos capazes de compreender a linguagem patêmica da música e das imagens de uma cena operística. Diante de uma ária, por exemplo, percebemos se o sujeito está em estado eufórico ou disfórico a partir do andamento da música e da

\footnotetext{
74 "Estratégias de aprendizagem e de uso da língua estrangeira são passos ou ações selecionados pelos aprendizes para melhorar a aprendizagem ou o uso da língua, ou ambos. [...] [S]ão pensamentos e comportamentos conscientes que os alunos utilizam para facilitar as tarefas de aprendizagem e personalizar o processo de aprendizagem da língua". COHEN, Andrew D., WEAVER, Susan J, \& LI, Tao-Yuan. The impact of strategiesbased instruction on speaking a foreign language. Minneapolis: National Language Resource Center/ The Center for Advanced Research on Language Acquisition, 1996. 48 p. (Relatório) apud PAIVA, 1998, p.73.

${ }^{75}$ Sigo a classificação de Rebecca Oxford (1989) para a distinção das estratégias de aprendizagem mobilizadas pelos alunos de língua estrangeira. Segundo a autora, as estratégias dividem-se em dois grandes grupos. O primeiro abrangeria três estratégias diretas de aprendizagem, ou seja, as de memória, as cognitivas e as de compensação. O segundo grupo abrangeria três estratégias indiretas de aprendizagem, que são as metacognitivas, as afetivas e as sociais. Entretanto, no trabalho com a ópera, todas as estratégias serão utilizadas de forma direta, e assumidas pelos alunos como "tarefas".
} 
velocidade dos gestos ${ }^{76}$. Portanto, podemos dizer que a primeira estratégia de aprendizagem dos alunos será a de perceber os afetos transmitidos pela música e pela encenação.

À medida que a ópera avança e os alunos constroem o contexto do melodrama, a percepção dos afetos tornar-se-á mais apurada, e será possível perceber não apenas sentimentos suscetíveis de apreensão imediata ${ }_{2}$ como a felicidade ou a tristeza, o amor ou o ódio, mas também sentimentos que requerem uma percepção mais cuidada, como a saudade, a inveja ou a vergonha, por exemplo.

Para que essa estratégia seja realmente mobilizada, é muito importante pedir aos alunos que eles não se preocupem em entender o que será cantado, para que possam se concentrar apenas em experimentar as emoções/sensações da melodia, do canto, dos gestos dos atores, dos figurinos e de todos os elementos que compõem o cenário, já que a intelecção da língua constituirá o passo seguinte. Assim, podemos dizer que, a despeito da classificação de Oxford, esta didática prevê uma utilização direta da estratégia afetiva de aprendizagem.

\subsubsection{Segunda fase: A leitura da legenda}

Durante a segunda visão da cena, desta vez com a legenda, o aluno deverá proceder a uma leitura do texto que vise à confirmação dos afetos percebidos na visão anterior. Em outras palavras, ele deverá verificar se e como os elementos eufóricos e disfóricos apreendidos anteriormente foram verbalizados pelos atores.

Podemos dizer que se trata de uma primeira etapa de reconstrução do sentido, já que a legenda constitui um novo elemento inteligível que impele a um melhor entendimento da cena.

Eventualmente, será possível que ele consiga justificar, ilustrar e até argumentar os afetos sentidos a partir da leitura da legenda, o que dependerá da quantidade de informação que ele conseguirá captar do texto. Os elementos inter-relacionados aos afetos serão úteis

\footnotetext{
76 A disforia abrange todos os sentimentos negativos, enquanto a euforia abrange os sentimentos positivos. Assim, podemos dizer que o ódio, o rancor, a raiva, o medo, etc. são sentimentos disfóricos, e o amor, a ternura, a amizade, etc. são sentimentos eufóricos.
} 
porque provavelmente servirão de referência para a próxima etapa do percurso, ou seja, a leitura da cena no libreto ${ }^{77}$.

Entre as estratégias cognitivas mobilizadas nesta fase, podemos ressaltar a de apreender a ideia com rapidez, ou seja, achar a ideia principal (skimming) e a de tomar nota dos afetos e dos elementos a eles relacionados.

\subsubsection{Terceira fase: A leitura do libreto ${ }^{78}$}

"Interpretatio linguarum, seu de ratione convertendi et explicandi autores tam sacros quam profanos." 79

Lawrence Humphrey

Primeiramente, os alunos procederão a uma leitura global da cena para observar, novamente, a correspondência entre a cena vista e descrita no libreto. Trata-se de uma leitura extensiva, superficial e abrangente a princípio - o que não exclui o uso do dicionário - que levará o aluno a confirmar (ou não) suas hipóteses de sentido feitas durante as visões da cena.

É sobretudo nesta fase que adentramos no campo exploratório da paráfrase, visto que a compreensão e interpretação do texto se darão a partir da reformulação do próprio texto poético.

Segundo Blumenschein (1997, p. 1, grifo meu), a paráfrase não está "presente como estratégia em sala de aula, apesar da significativa frequência com que, intuitivamente, ocorre na prática de ensino".

Araken Guedes Barbosa vai mais além e situa a paráfrase "num plano de grande importância para a aquisição da linguagem". De acordo com sua tese, "a versatilidade cognitiva ensejada pelo parafrasear leva o aprendiz a fazer escolhas, a combinar conceitos formando estruturas semânticas capazes de realizar uma comunicação adequada e satisfatória" (BARBOSA, 2005, p. 89).

\footnotetext{
${ }^{77}$ De acordo com Fuchs (1982a), o conhecimento da referência de certos termos pode estabelecer uma relação parafrástica com o texto origem.

${ }^{78} \mathrm{O}$ libreto utilizado no curso "Rigoletto: per gli amanti della lingua e della cultura italiana" encontra-se no anexo A.

79 "A interpretação de enunciados sob a luz da razão é capaz de converter e explicar tanto os autores sacros quanto os profanos" (trad. de Araken Barbosa).
} 
As impressões de Blumenschein e a tese de Barbosa parecem, de fato, responder aos anseios de Paolo Balboni sobre um estudo mais profundo da paráfrase e de sua aplicação no ensino da língua estrangeira.

Se tal é a importância psicolinguística da paráfrase, surpreende o uso redutivo que se faz dela em italiano (em que é frequentemente reduzida à conversão em prosa de textos poéticos do passado) e, sobretudo, surpreende a sua ausência no ensino da língua estrangeira: neste caso, parafrasear equivale a pensar em língua estrangeira, realizando a antiga sugestão segundo a qual: "não precisa traduzir do italiano para a língua estrangeira, precisa pensar diretamente nesta última" (BALBONI, 2002, p. 65-66, tradução minha). ${ }^{80}$

Concordo mais uma vez com Balboni e, por isso, ressalto a importância do uso da paráfrase neste estudo não apenas como uma forma de atualizar o texto antigo da ópera, mas, sobretudo, utilizá-la como estratégia cognitiva para compreender o libreto.

Em primeiro lugar, para legitimar a função da paráfrase na compreensão do texto literário, é preciso considerá-la uma prática metalinguística espontânea e intrínseca à competência de qualquer falante. De acordo com Parret (1988, p. 225), a paráfrase é uma transposição discursiva "exercida naturalmente e infinitamente pelos discursos tanto cotidianos como artísticos e poéticos", cuja "semelhança do sentido transposto e do sentido transpositor está intuitivamente posto".

Para ilustrar o uso da paráfrase em sala de aula, basta dizer que, desde a primeira aula, professor e aluno recorrem a ela para não precisar traduzir em língua materna. As expressões "o que quer dizer" e "o que significa" indicam um problema na compreensão de determinado enunciado que o professor tentará resolver dizendo de outra forma. Para Blumenschein, a paráfrase pode "mediar e facilitar o aprendizado por ser uma outra forma de dizer". De fato, podemos definir paráfrase como "uma atividade de substituição sinonímica que pressupõe a presença de um enunciado de origem (problema) e um enunciado equivalente (solução)" (BLUMENCHEIN, 1997, p. 8).

Entretanto, um único texto pode produzir inúmeras paráfrases, que podem variar da “mera repetição, com alguns apagamentos ou acréscimos, até um afastamento significativo no

\footnotetext{
80 "Se tale è l'importanza psicolinguistica della parafrasi, stupisce l'uso riduttivo che se ne fa in italiano (dove viene spesso ridotta alla resa in prosa di testi poetici del passato) e, soprattutto, stupisce la sua assenza nell'insegnamento della lingua straniera: in questo caso parafrasare equivale a pensare in lingua straniera, realizzando l'antico suggerimento secondo il quale: 'non bisogna tradurre dall'italiano in lingua straniera, bisogna pensare direttamente in quest'ultima'".
} 
qual se nota apenas um tênue matiz com o texto original" (BLUMENCHEIN, 1997, p. 1). A única restrição é que os enunciados sejam "semanticamente equivalentes", de acordo com o princípio da elasticidade do discurso ${ }^{81}$.

A necessidade da paráfrase na compreensão do texto operístico explica-se pelo fato de a língua reunir, na ópera, aspectos formais que, por vezes, apresentam-se como um desafio à sua compreensão, sobretudo da parte do aluno, que ainda não domina a língua estrangeira. Nosso objetivo é que, cada vez mais, e de forma mais autônoma, o aluno consiga formular paráfrases para desvencilhar-se das carências lexical e sintática inevitáveis.

Ora, se a competência textual é baseada em um "mecanismo parafraseador" (Mel'cuk, 1976, apud BALBONI, 1998, p. 65) ${ }^{82}$ capaz de transformar uma estrutura profunda em uma estrutura superficial, compreender um texto literário é proceder, implicitamente, à sua paráfrase. Segundo Eco (1991, p. 128), “a prova mais cabal de compreensão de um texto é dada quando conseguimos parafraseá-lo sem tê-lo diante dos olhos, significando que não só não o copiamos como o entendemos".

Em última instância, a própria definição de "estratégia cognitiva" subentende o ato de parafrasear um texto em língua estrangeira: "Estratégias cognitivas: compreensão e produção de novos enunciados através da manipulação e da transformação da língua-alvo pelo aprendiz" (PAIVA, 1998) ${ }^{83}$.

Assim, a língua-alvo inscrita no libreto será manipulada e transformada pelos alunos na reformulação do texto operístico, resultando na produção de enunciados perfeitamente inteligíveis e semanticamente equivalentes aos enunciados do texto original.

Diante do texto literário escrito, o aluno tentará a compreensão ativando seus mecanismos parafrásticos naturais de substituição, apagamento, deslocamento ou acréscimo para explicar, definir, exemplificar, resumir ou sintetizar os enunciados poéticos do libreto.

Dentro dessa perspectiva, as estratégias cognitivas mais operacionalizadas serão as de inversão poética, a passagem do discurso direto ao discurso indireto, a sinonímia lexical (com a utilização do dicionário), a atualização da língua antiga (também com o uso do dicionário), a inferência semântica e a desambiguação.

\footnotetext{
${ }^{81}$ Cf. GREIMAS; COURTÉS, 2008, p. 157.

${ }^{82}$ MEL'CUK, I. "Eine linguistisches Modell des Typs 'Smysl-Text”, In: GIERRE, W.; JACHNOW, H. (org.) Theoretische Linguistik in Osteuropa, Niemeyer: Tubinga, 1976.

${ }^{83}$ PAIVA, V.L.M.O. Estratégias individuais de aprendizagem de língua inglesa. Letras e Letras. v. 14, n. 1, jan./jul. 1998. p. 73-88.
} 
Portanto, o papel do didatizador do material autêntico será o de tornar o input literário compreensível por meio 1) da utilização de outras expressões, como, no nosso caso, da música e da encenação e 2) de tarefas que incitem os alunos a ativarem tais mecanismos parafrásticos e a procederem as estratégias acima referidas.

Sendo assim, esta metodologia pretende incentivar a prática do parafrasear de uma maneira consciente, sistemática e monitorada para que não apenas a compreensão, como também a produção dos alunos, alcance níveis linguísticos satisfatórios.

\subsection{PRERROGATIVAS DIDÁTICAS PARA O USO AUTÊNTICO DA ÓPERA}

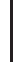

A partir das considerações feitas até aqui, vejamos quais são, de fato, as principais vantagens decorrentes de se trabalhar a ópera como um material autêntico_não-adaptado.

\subsubsection{Motivação}

O italiano é a 5á língua europeia e a 14aㅡ no mundo segundo o número de falantes, calculados em aproximadamente 60 milhões de pessoas (Crystal, 1991). Dentre as principais motivações que concorrem para o estudo dessa língua no mundo encontramos, em primeiro lugar, o "lazer", como podemos verificar no gráfico abaixo ${ }^{84}$.

\footnotetext{
${ }^{84}$ Reporto-me à pesquisa realizada por Tulio de Mauro e Massimo Vedovelli publicada no livro Italiano 2000: I pubblici e le motivazioni dell'italiano diffuso fra stranieri. Roma: Bulzoni, 2003.
} 


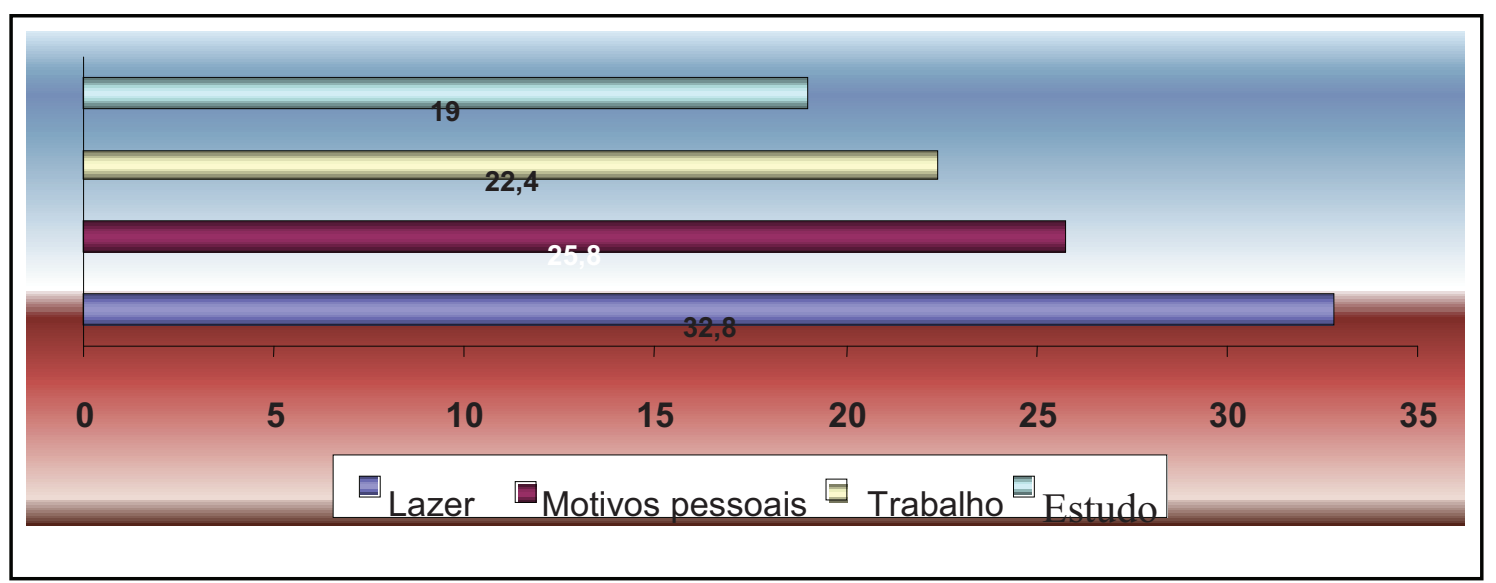

Gráfico 1. Principais motivações para o estudo do italiano como língua estrangeira

Especificamente, os fatores que constituem a motivação "lazer" obedecem a seguinte ordem de interesse:

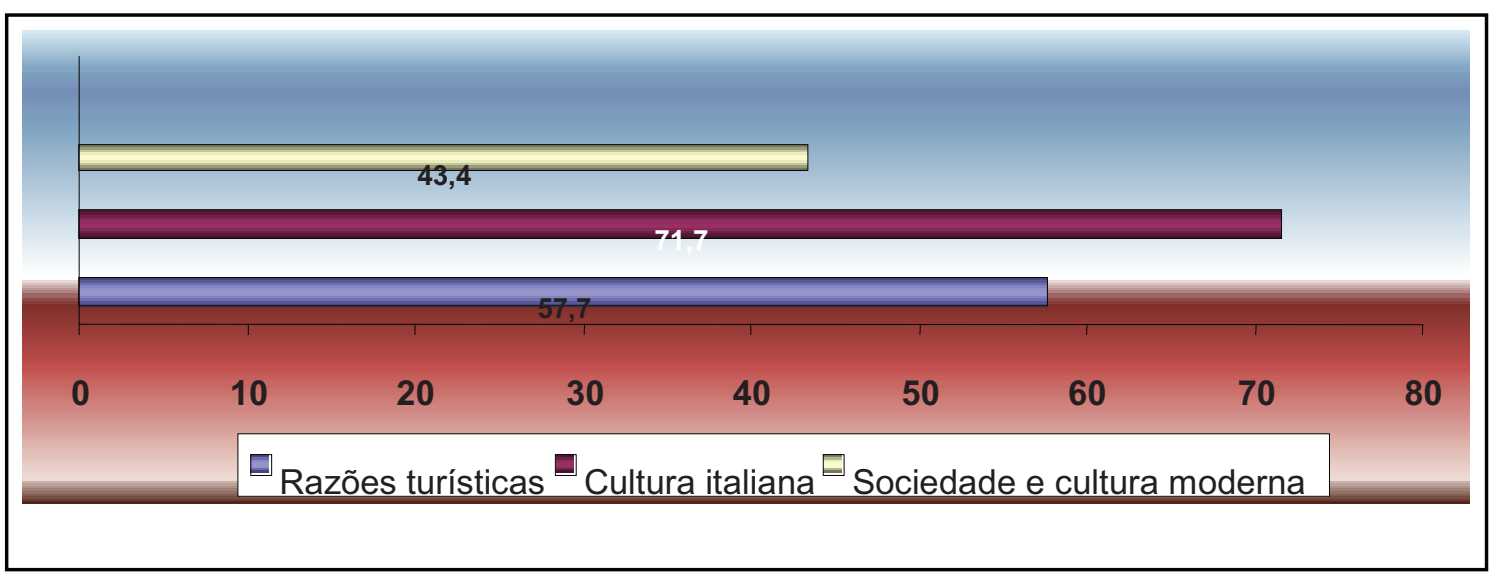

Gráfico 2. Fatores que constituem a motivação "lazer" no estudo do italiano como língua estrangeira

Em primeiro lugar, esses dados confirmam que a motivação em estudar o italiano se associa, em grande parte, ao conhecimento da cultura italiana. Além disso, podemos intuir que o ensino-aprendizagem da língua italiana no mundo está diretamente relacionado ao quererfazer e, portanto, ao prazer. Transferindo essa motivação para a esfera da necessidade, tendo em vista a teoria sobre a "análise das necessidades" no ensino-aprendizagem de línguas estrangeiras ${ }^{85}$, podemos considerar a necessidade do prazer um item essencial no ensino do italiano LE.

\footnotetext{
${ }^{85}$ Cf. BALBONI, 2002, p. 90-92.
} 
As duas forças que podem envolver a personalidade e levá-la a "querer" são a necessidade e o prazer. Nesse sentido, é preciso fazer com que os alunos descubram que têm necessidade de literatura e que a literatura pode dar a eles prazeres extraordinários (BALBONI, 2006b, p. 10, grifo meu).

Portanto, o intuito primordial deste projeto é promover o contato do aluno de língua estrangeira com a cultura da língua-alvo em sua real dimensão, sem que o filtro de outra cultura ${ }^{86}$ apague ou reduza o seu valor de objeto/fonte de conhecimento.

O aluno que opta por um curso cujo objeto de estudo é a ópera encontra-se, desde o início, predisposto ao contato com o objeto e, portanto, carrega consigo uma motivação intrínseca de querer-fazer.

Entretanto, devemos considerar também entre o nosso público o aluno curioso, cujo interesse inicial tende mais para a afinidade com a língua italiana e para a sua cultura de um modo geral que propriamente para a ópera. Esse aluno deseja conhecer o objeto, sem saber se o apreciará ou não. Embora sua motivação já tenha sido capaz de superar os estereótipos do gênero, devemos cuidar para que ele faça uma avaliação positiva dos estímulos (ou inputs), que, nesta primeira fase, é determinada pela novidade e pela atratividade do objeto ${ }^{87}$.

Então, é possível imaginar o quão desapontador seria, tanto para o apreciador do gênero, quanto para quem o deseja conhecer, estudá-lo adaptado, simplificado ou reduzido; destituído de suas qualidades estéticas e artísticas, de sua complexidade e autenticidade. De fato, o inscrito no curso está motivado para o contato com o objeto no original, e é somente no original que podemos encontrar a plenitude do seu valor cultural e toda a sua valência expressiva, o que constitui condição sine qua non para manter tanto os amantes da ópera quanto os interessados em estudar a cultura italiana motivados.

É preciso destacar, enfim, que na didática de línguas estrangeiras o prazer é tido como uma "motivação essencialmente ligada ao hemisfério direito, mas que pode envolver também o hemisfério esquerdo, tornando-se de tal forma potentíssima”_(BALBONI, 2006b, p. 38).

Por isso, além de responder à necessidade do aluno de obter o prazer pelo contato com o objeto autêntico, este curso fará frente à análise linguística e semiótica do texto operístico com o fim de promover também a aquisição do input pelo aluno.

\footnotetext{
${ }^{86}$ No caso de ele ser paradidatizado por um estrangeiro.

${ }^{87}$ Cf. modelo stimulos appraisal, em Schumann, 1997.
} 
Por outro lado, é natural que o aluno, diante do objeto em sua dimensão real - ainda mais se tratando de um objeto como a ópera - sinta-se, a todo o momento, desafiado. De fato, conhecer, entender, interpretar e perfazer o melodrama constituem objetivos primários e desafios permanentes dos inscritos no curso.

Assim, é também muito importante que o professor sinta-se seguro e entusiasmado ao apresentar a ópera no original, sob pena de ativar o filtro afetivo do aluno. O seu papel será sempre o de estimular o contato (e apaziguar o conflito) do aluno diante do objeto, que, como já dissemos, representa o alheio, o outro e o novo.

Ao final deste percurso, espera-se que o aluno se motive também a conhecer outras óperas no original, contando apenas com os elementos de que o público autêntico dispõe, ou seja, o espetáculo, o libreto e, eventualmente, um bom dicionário.

\subsubsection{Formação}

O fato de apresentarmos o objeto "ópera" na sua forma autêntica já representa, por si só, um empenho no sentido de formar o aluno de língua estrangeira, pois o conteúdo cultural e intelectual inerente às obras certamente refletirá no discurso e no comportamento do aluno.

[...] a compreensão ativa do que foi ouvido pode realizar-se diretamente como um ato, pode permanecer, por certo lapso de tempo, compreensão responsiva muda (certos gêneros do discurso fundamentam-se apenas nesse tipo de compreensão, como, por exemplo, os gêneros líricos), mas neste caso, trata-se de uma compreensão responsiva de ação retardada: cedo ou tarde o que foi ouvido e compreendido de forma ativa encontrará um eco no discurso ou no comportamento subsequente do ouvinte (BAKHTIN, 1992, p. 291).

Mas, no nosso caso, a simples ação didática sobre o objeto já pressupõe que a compreensão do aluno não seja, em nenhum momento, responsiva muda, porque, de fato, ele sincretizará seu papel de ouvinte/receptor à própria função (re)ativa de aluno.

Como vemos, Bakhtin concebe a função comunicativa da linguagem como um processo dialógico entre emissor e receptor da mensagem - e não mais apenas como o transporte da mensagem de um emissor para um receptor. Nesse sentido, é essencial que os 
cursos de LE adotem a concepção bakhtiniana para que a função do aluno seja, realmente, ativa dentro do processo de ensino-aprendizagem de língua estrangeira.

Isso já seria o bastante para que pudéssemos falar em formação discente, mas, além de conceber a comunicação de outro modo, é preciso considerar também que determinadas “intercepções” na mensagem podem alterar o processo formativo do aluno.

De fato, se considerarmos o adaptador do texto autêntico um interceptador da mensagem (ou do enunciado), podemos afirmar que, ainda que o material adaptado permita uma recepção ativa por parte do aluno - por ser literatura ${ }^{88}$ - a atividade interacional não ocorreria mais entre enunciador-autor e enunciatário-aluno, mas cederia lugar à interação entre enunciador-adaptador e enunciatário-aluno. Inevitavelmente, a intercepção do adaptador impede o dialogismo entre emissor autêntico e aluno e, como consequencia, prejudica a formação discente.

Portanto, problematizar a formação discente implica em reavaliar não apenas o conteúdo do que é transmitido, mas, acima de tudo, em reavaliar os níveis de autoria do discurso e suas consequências na intelecção da mensagem.

Transmitir um conteúdo que responda às exigências intelectuais do aluno, bem como garantir sua compreensão ativa autêntica reflete, enfim, na "importância da aquisição linguística da segunda língua não simplesmente como instrumento comunicativo, mas, sobretudo, como fator formativo voltado ao desenvolvimento da inteira personalidade do discente" (TITONE ${ }^{89}, 1996$ apud PONZIO, 2001, p. 56, tradução minha).

\subsubsection{Autonomia}

A terceira e última prerrogativa para se apresentar o material operístico de forma autêntica sugere, novamente, a complexidade da ópera a favor do aprendizado. As estratégias

\footnotetext{
88 "De fato, os gêneros literários são tipos particulares do tipo geral dos gêneros do discurso e jogam um papel fundamental em relação ao problema do diálogo e do dialogismo interno à enunciação" (PONZIO, 2001, p. 59, tradução minha): "Infatti i generi letterari sono tipi particolari del tipo generale dei generi del discorso e giocano riguardo al problema del dialogo e del dialogismo interno all'enunciazione un ruolo fondamentale".

${ }^{89}$ TITONE, R., (Org.) La personalità bilíngüe. Caratteristiche psicodinamiche. Milão: Bompiani, 1996: “[...] l'importanza dell'acquisizione linguistica della seconda lingua non semplicemente come strumento comunicativo, ma soprattutto come fattore formativo rivolto allo sviluppo dell'intera personalità del discente".
} 
de aprendizagem que os alunos deverão mobilizar para compreender o melodrama são aplicáveis também na compreensão de outras formas discursivas e, portanto, visam a melhorar desde a observância à entonação e aos gestos dos falantes e sua relação com a linguagem verbal até as habilidades linguísticas do aluno ${ }^{90}$.

É fato que a complexidade do gênero exigirá um maior empenho tanto emotivo quanto cognitivo do aluno para que haja, em primeiro lugar, a compreensão do input. Do mesmo modo, é fato que todas as atividades deverão agir contra a complexidade linguística do gênero, guiando o aluno até a sua efetiva compreensão e interpretação.

Importante é que os alunos construam em seu percurso estratégias e conhecimentos suficientes para enfrentar essas dificuldades, preparando-se assim para a autonomia linguistica_necessária e para a complexidade que é da língua, dos textos, dos discursos e da vida e integrando a compreensão e a produção, a exposição à língua e seu uso, a interpretação das estruturas e sua utilização para alcançar seus objetivos (SANTORO, 2007, p. 185).

Portanto, é por meio das atividades que o aluno encontrará os instrumentos para “sobreviver" à complexidade linguística e superá-la a cada cena da ópera, tornando-se cada vez mais autônomo para enfrentar a complexidade dentro e fora da sala de aula.

Com a convicção de que a didática de línguas estrangeiras deve caminhar em direção à “autoaprendizagem" do discente, este estudo propõe um curso em que o aluno poderá lidar com a complexidade do material autêntico a partir das tarefas, realizadas sempre em grupo, de modo redundante e com o apoio da linguagem não-verbal, o que os incitará à autonomia linguística por meio, sobretudo, da paráfrase, bem como à autonomia de análise valendo-se da semiótica.

\footnotetext{
${ }^{90}$ No âmbito das habilidades, é válido acrescentar às quatro "habilidades primárias" de escutar, ler, falar e escrever, as "habilidades integradas", ou seja, saber dialogar, parafrasear, resumir, tomar notas e escrever sob ditado. Segundo Balboni (1998), um modelo que inclua ambas as habilidades parece mais adequado à descrição da comunicação, haja vista a complexidade do discurso desenhada pelo próprio Bakhtin: o diálogo, por exemplo, não pode ser considerado apenas uma soma de falar e escutar, mas a integração de ambas que se dá tanto no eixo produtivo quanto no eixo receptivo.
} 


\section{A DIDATIZAÇÃO DA ÓPERA NAS AULAS DE LÍNGUA ESTRANGEIRA}

Depois de discorrer sobre a importância de se colocar o aluno diante do objeto na forma pela qual foi concebido por seu(s) autor(es), tentarei demonstrar como o material autêntico pode ser trabalhado metodologicamente, ou seja, como pode ser didatizado a serviço de uma educação que considere, em toda a sua complexidade, o que deve ser ensinado/aprendido nas aulas de língua estrangeira, não somente de acordo com os objetivos preestabelecidos, mas também para perseguir metas.

Assim, o como se trabalhar um material autêntico é determinante para legitimar o seu uso nas aulas de língua estrangeira. Nas palavras de Patricia Franzoni (1992, p. 49):

É frequente, no âmbito da pedagogia de línguas, a observação de que o material autêntico pode ser trabalhado com metodologias que apagam qualquer vantagem desse tipo de material em confronto com material não-autêntico.

Essa observação é altamente coerente com a abordagem superficial e prosaica que os manuais insistem em adotar, sobretudo, com relação aos textos literários. Em nome de um errôneo enfoque linguistico, permanece-se na superfície do texto, desconsiderando os avanços da própria Linguistica no estudo da literatura.

Curiosamente, a partir do auge da abordagem comunicativa, afirmouse, portanto, uma posição que, em relação à presença da literatura na sala de aula de língua estrangeira, revela mais pontos de contato com a concepção tradicional, que - como vimos - tratava o texto literário como objeto de "veneração", do que com as metodologias posteriores, nas quais começaram a ganhar espaço visões muito mais dinâmicas e abrangentes de língua e aprendizagem (SANTORO, 2007, p. 19).

Examinando os principais manuais de língua italiana para estrangeiros ${ }^{91}$, é possível generalizar o percurso didático adotado na abordagem do texto literário nas fases de compreensão, análise lexical, gramática e produção oral ou escrita.

\footnotetext{
${ }^{91}$ Foram examinados os manuais Linea Diretta $1 a, 1 b$ e 2 e Espresso 1,2 e 3.
} 
Antes de tudo, é preciso dizer que dois requisitos básicos são indispensáveis para determinar a inserção daquele texto em uma unidade didática: o tema e a utilização de estruturas convenientes para o nível linguístico em questão.

$\mathrm{Na}$ fase de compreensão, é raro encontrar perguntas que não sejam estritamente referenciais, denotativas, que exijam apenas a apreensão de elementos explicitados no texto. Em seguida, passa-se a exercícios de léxico e de gramática, que ainda visam à compreensão textual, além do estudo formalístico do texto. Por fim, aproveita-se o tema para que o aluno possa falar ou escrever sobre suas experiências pessoais e, eventualmente, expressar sua opinião sobre o assunto tratado, numa abordagem conhecida como humanístico-afetiva.

Infelizmente, não se aprofunda a análise do texto, não se passa do referencial ao inferencial, do explícito ao implícito, do enunciado à enunciação, do produto à produção. Não se valoriza, enfim, o que se deveria valorizar em um texto literário!

De fato, para que a didatização do material autêntico valha à pena, é preciso fazê-lo sob um enfoque que não despreze o seu real valor e a(s) sua(s) finalidade(s) específica(s), tendo em vista, sempre, os objetivos didáticos propostos.

\subsection{OS INSTRUMENTOS DE ANÁLISE}

Ciente de que o ensino do texto literário nas aulas de língua estrangeira não deve se limitar ao código linguístico utilizado, mas, ao contrário, merece ser abordado na sua significação completa, recorro a uma metodologia que estuda todos os fenômenos culturais como se fossem sistemas sígnicos, isto é, sistemas de significação. Essa ciência é a semiótica (do grego semeiotiké ou "a arte dos sinais"), que integra o estudo das artes em geral aos meios linguísticos e extralinguísticos de que dispomos para significar no mundo.

Como vimos no capítulo 2, a ópera é um gênero que prima pela música (muitas vezes em detrimento do libreto), o que nos permite sugerir que é ela quem determina o sentido do texto.

Ora, se é a música quem determina o sentido do texto, ou, pelo menos, se a música é determinante para se chegar ao sentido do texto, seria mais adequado proceder a um tipo de análise que considere, em muito, a linguagem musical e, por conseguinte, a emoção, visto que 
a linguagem musical está totalmente ligada à emoção e ao sentimento. Por isso, este trabalho utilizará como instrumento de análise a Semiótica das Paixões, um postulado greimasiano que concebe a "paixão como o que impele o homem à ação e o que o eleva às grandes coisas" 92 . Afinal, nada mais adequado ao estudo da ópera, um gênero em que as paixões estão no âmago da sua significação.

\subsubsection{A Semiótica das Paixões}

"O tempo é a medida do afeto."

Luiz Tatit

A Semiótica das Paixões é um postulado teórico que busca (re)organizar o último nível do percurso gerativo proposto pela semiótica francesa ${ }^{93}$, a saber: o nível profundo. De fato, esse nível sempre foi menos privilegiado que os níveis discursivo e narrativo por trazer questões de ordem filosófica, do domínio do $\operatorname{ser}^{94}$.

Considera-se que o sujeito e o objeto formam um uno, um continuum, em que há felicidade, mas, por outro lado, não há sentido. Até que ocorre a cisão entre o sujeito e o objeto, que levará inevitavelmente à busca pela integridade primordial, instituindo, assim, o sentido. Desta forma, "o sentido stricto sensu não seria outra coisa senão a direção assumida pelo sujeito no intuito de reencontrar o objeto" (TATIT, 1998, p. 93).

Nesse nível, o estado de junção entre sujeito e objeto é modulado por categorias tensivas e fóricas. Há uma tensividade original que, na preservação do uno, assegura a identidade integral do sujeito (protensividade do sujeito mais potencialidade do objeto). Quando ocorre a cisão, procede-se a um jogo de oscilações tensivas, que se referem à percepção do ser, impelindo o sujeito ao restabelecimento do uno e, assim, à recuperação da própria identidade.

\footnotetext{
92 FIORIN, J. L. Semiótica das Paixões: O Ressentimento. Editorial. Revista Alfa, vol. 51, n. 1, p.2, 2007.

${ }^{93}$ A semiótica francesa baseia-se na teoria de A. J. Greimas sobre a construção dos sentidos e se preocupa em reconstituir o simulacro da significação a partir de um conjunto de níveis de significação, que parte do mais abstrato ao mais concreto, ou seja, um percurso que passaria pelas instâncias mais simples de geração do sentido, adquirindo maior concretude à medida que se elevasse o nível (FONTANILLE, 2001).

${ }^{94}$ Nos últimos anos de sua vida, Greimas publicou De l'imperfection (1987) e Sémiotique des passions (1991), este em colaboração com J. Fontanille. Ambas as obras trazem a proposição de um nível de precondições para a geração do sentido, no qual inseriu os estágios contínuos que nem sempre podem ser submetidos à discretização e às reduções categoriais próprias dos estágios intelectivos (TATIT, 1998).
} 
A noção de percepção pressupõe a noção de sentimento, pertencente ao domínio da foria. Nesse sentido, a predominância dos estados de retenção, de tensão sentimental, pressupõe a disforia, ou seja, o sujeito em disjunção com o objeto, enquanto a predominância dos estados de distensão (ou relaxamento) pressupõe a euforia, quando o sujeito está em conjunção com seu objeto.

Articulando em tempo e espaço, a conjunção designa a continuidade discursiva, enquanto a disjunção designa a descontinuidade discursiva. E são exatamente as categorias de continuidade e descontinuidade que envolvem as reflexões sobre o tempo semiótico, considerando-se as variações de velocidade como parâmetro fundamental para o seu estudo.

Em primeiro lugar, devemos entender que as variações afetivas são tributárias dos valores juntivos (conjunção e disjunção). O apego e o desapego dão margem a uma infinidade de formas que, a julgar pelo tempo cinemático (o andamento mais lento ou mais rápido manifestado nas categorias de aceleração e desaceleração), instituem no sujeito a distância (ou duração) "ideal” para se situar em relação ao seu objeto de desejo ${ }^{95}$.

Desta forma, a união e a ruptura são formas rápidas, instantâneas, que definem, respectivamente, apego e desapego; enquanto a aproximação e o distanciamento são formas lentas e gradativas concernentes a apego e desapego (ZILBERBERG, 1995 apud TATIT, 1998) ${ }^{96}$.

Procedendo nesta análise, uma união no auge da sua aceleração leva o sujeito ao êxtase, e o mesmo estado desacelerado supõe a felicidade. Por outro lado, a ruptura, em sua máxima aceleração, pode representar um sujeito liquidado, ao passo que a ruptura desacelerada desencadeia os afetos de depressão, prostração, abatimento, etc.

Além disso, é interessante notar como, no estudo sobre a "velocidade dos afetos" proposto pela Semiótica das Paixões, os afetos (ou emoções) pontuais - aqueles que já possuem um estatuto linguistico-cultural definido - vão iluminando, pouco a pouco, as etapas do continuum passional (TATIT, 1998). A definição de angústia, por exemplo, foi

\footnotetext{
${ }^{95}$ Para ilustrar as categorias de continuidade e descontinuidade discursivas delineadas pela Semiótica das Paixões, recorro a um clássico exemplo dentro do nosso cotidiano, a canção "Garota de Ipanema", de Vinícius de Moraes e Tom Jobim. De fato, o andamento é acelerado quando o sujeito está em conjunção com o objeto ("olha que coisa mais linda / mais cheia de graça / é ela menina / que vem e que passa [...]"), e desacelerado diante da disjunção entre eles ("ah, como estou tão sozinho / ah, como tudo é tão triste!"). Informação fornecida por Luiz Tatit no curso "Semiótica: Teoria e Aplicação na Canção Brasileira", durante o segundo semestre de 2006.

${ }^{96}$ ZILBERBERG, C. Plaidoyer pour le tempo. In: FONTANILLE, J. (ed.). Le devenir. Limoges: Pulim, 1995.
} 
dicionarizada com a seguinte formulação: "1 estreiteza, redução de espaço ou de tempo, carência, falta 2 estado de ansiedade, inquietude; sofrimento, tormento [...]" (Houaiss, 2001, p. 220).

Embora a Semiótica das Paixões esteja fundamentada em um arcabouço teórico muito maior, os conceitos delineados até aqui parecem ser suficientes para justificar o seu emprego metodológico na didatização da ópera lírica. De fato, na ópera encontramos a representação de inúmeros afetos pontuais definidores do estado do sujeito em todos os seus planos de linguagem.

A própria separação entre recitativo e ária é uma fonte didática insuperável para a ilustração das categorias de continuidade e descontinuidade discursiva. No recitativo temos a extensão musical, gestual e linguistica. Na ária, ao contrário, temos a contensão dessas mesmas linguagens, expressando magistralmente o estado passional do sujeito.

Em outras palavras, a diferença entre recitativo e ária, nas obras maduras, é como a diferença entre a linguagem prosaica e a linguagem poética nos três planos da expressão (cênico, literário e musical). No recitativo, simula-se o caminhar e o falar, os gestos são mais rápidos, a língua é mais inteligível e a música limita-se ao acompanhamento (temos aqui a continuidade discursiva). Na segunda, os personagens estão quase imóveis; apenas os braços se movem e a boca se abre em gestos e movimentos lentos e arrastados; a compreensão linguística torna-se bem mais complexa e a música transborda emoção (temos, então, a descontinuidade discursiva).

A análise dos afetos na ópera torna-se, portanto, bastante fecunda pelo fato de o gênero ilustrar musicalmente a tensividade-fórica ${ }^{97}$ do sujeito com relação ao seu objeto de desejo. Assim, os estados juntivos entre sujeito e objeto podem ser apreendidos pela música e, posteriormente, verificados no texto operístico, o que escusaria um contato direto com a complexidade linguistica sem deixar de estabelecer um primeiro contato inteligível com o objeto. E à medida que se seguirá o enredo, o papel da música adquirirá um significado cada vez maior na análise dos afetos, a ponto de poder prescindir do próprio texto.

\footnotetext{
${ }^{97}$ A tensividade-fórica é uma instância que combina a percepção e o sentimento do ser em relação ao seu objeto. A priori, todos os efeitos passionais ou patêmicos são preenchidos de um determinado grau de tensividadefórica.
} 
Como a didatização da ópera vai "da emoção à razão", passemos agora às operações cognitivas adotadas para a compreensão e interpretação dos programas narrativos e, enfim, do discurso.

Essencialmente, as modulações tensivo-fóricas sofridas pelo ser se narrativizam por meio de "transformações" operadas pelos actantes. No plano narrativo, poderemos identificar facilmente os enunciados de estado percebidos no nível fundamental, que descrevem a relação de junção entre sujeito e objeto. Esses enunciados serão regidos pelos enunciados de fazer, supondo a atitude do sujeito em transformar seu estado primário. Assim, "os enunciados de fazer operam a passagem de um estado a outro, ou seja, de um estado conjuntivo a um estado disjuntivo e vice-versa" (BARROS, 2002, p. 30).

Entretanto, o fazer pressupõe modalidades específicas, considerando-se que, no programa narrativo, o enunciado de fazer "modaliza" o enunciado de estado descritivo, de maneira que o sujeito, investido de um /querer-fazer/, /dever-fazer/, /poder-fazer/ ou /saberfazer/, atualizará seu estado juntivo em relação ao seu objeto de valor.

Os actantes que, nessa fase, contribuirão para a atualização do ser (virtualizado no estágio precedente) correspondem não apenas às figuras de sujeito e objeto, como também de destinador-manipulador (ex. um antagonista) e destinador-julgador (ex. Deus ou o destino). O destinador-manipulador é quem age sobre o sujeito e lhe institui o querer ou o dever fazer; disso pressupõe-se que o próprio sujeito adquire uma competência e, assim, modaliza-se a poder ou saber fazer. Em seguida, esse sujeito procede a uma performance, realizando a transformação central da narrativa. Finalmente, temos o destinador-julgador, que verifica a realização da performance do sujeito e a julga por meio de um "prêmio" ou um "castigo".

$\mathrm{Na}$ instância superior, os esquemas narrativos são assumidos pelo enunciador, que os converte em discurso. Na última fase do percurso gerativo, temos as projeções da enunciação no enunciado, além dos recursos de persuasão utilizados pelo enunciador para manipular o enunciatário e a cobertura figurativa dos conteúdos narrativos abstratos (BARROS, 2002).

As projeções realizam-se por meio de deslocamentos espaciais, defasagens temporais e transferências actanciais que promovem um desengate geral das principais balizas que sustentam o presente enunciativo: eu-aqui-agora. Isso porque "todo enunciado, uma vez emitido, afasta-se dessa condição pura de enunciação, desfazendo a relação direta eu-tu em nome de uma outra cena que possui seus próprios agentes e suas próprias circunstâncias de tempo e espaço" (TATIT, 2001, p. 40). 
No caso da ópera, as projeções são presentificadas. Temos o apagamento do narrador, dando lugar à visão "direta” das coisas, ou seja, os fatos visíveis e audíveis contam a história. Isso enriquece a narrativa por deflagrar um aqui e um agora, ao mesmo tempo em que os interlocutores reconstroem a relação $e u$-tu. Em outras palavras, podemos pensar em actantes discursivos, visto que a enunciação é abordada do ponto de vista de sua organização espetacular.

De fato, o modelo teatral (com prevalência do discurso direto) é polifônico por natureza, e as personagens e as vozes que integram o espetáculo identificam-se com os enunciadores cujos diferentes enfoques respondem pela heterogeneidade da enunciação (DUCROT, 1987).

Entretanto, nas árias, temos o caso de enunciação enunciada, em que um narrador sincretizado no papel de ator - fala em primeira pessoa, geralmente com as projeções simultâneas das categorias do tempo e do espaço em suas formas também presentificadas em aqui e agora.

Além disso, temos um narrador explícito no libreto que institui actantes, tempo e espaço a cada cena da ópera, limitando-se, porém, a descrever a cena.

O interesse em se desvelar todo o esquema de deslocamentos actanciais, temporais e espaciais implica no conhecimento dos procedimentos utilizados para a obtenção dos efeitos de sentido, além de produzir a ilusão completa de realidade.

É comum a todos os gêneros textuais o objetivo primário do enunciador de tentar persuadir o enunciatário com o seu discurso. Ele propõe um contrato, dito veridictório, que estipula como este deve interpretar a verdade do discurso.

Em primeiro lugar, devemos pensar que, por trás de toda a emoção que o gênero operístico intenciona transmitir ao seu enunciatário-ouvinte, engendram-se muitos programas narrativos responsáveis por dar vazão aos sentimentos do(s) sujeito(s). São os enunciados de fazer, regentes dos enunciados de estado, que causam o fazer-crer (convencimento) e o fazerfazer (persuasão) do enunciatário-leitor ${ }^{98}$. E os programas narrativos são, por sua vez, revestidos de discurso, ou seja, são concretizados semântica, temática e figurativamente.

\footnotetext{
98 A diferenciação entre o enunciatário-ouvinte e o enunciatário-leitor pressupõe também uma diferenciação entre as fases da audição dos sons e a fase de leitura do libreto.
} 
Em última análise, o enunciador da ópera intenciona fazer o enunciatário-ouvinte se emocionar (ou até chorar). Mas, para tanto, é preciso que o enunciatário-leitor se convença da narrativa proposta!

Uma ressalva muito importante deve ser feita com relação aos papéis de enunciador e enunciatário. De fato, "o fazer manipulador realiza-se no e pelo discurso, como um fazer persuasivo", e "o fazer interpretativo do enunciatário, que responde ao fazer persuasivo do enunciador, ocorre também no discurso-enunciado" (BARROS, 2002, p. 93).

Partindo-se do pressuposto de que "todas as opções feitas pela enunciação na produção do discurso são argumentativas" (BARROS, 2002, p. 110), o enunciador joga com a imagem que faz de si e do enunciatário para explicitar ou implicitar conteúdos - e assim pressupor e subentender; procede também à prática de certos atos linguisticos (ilocucionais) para atingir determinados fins (perlocucionais) e, de um modo geral, argumenta para persuadir.

Pode-se dizer que o estudo da sintaxe e da semântica discursivas aplica-se, em grande parte, ao estudo da retórica ${ }^{99}$, já que ambos preveem a análise dos mecanismos de funcionamento do texto sob a ótica da persuasão. Balboni, por exemplo, aproxima as disciplinas ao propor, para a didatização de textos literários, uma metodologia que acentue "a dimensão semiótica, textual, que leva o aluno a descobrir o que torna literário um texto e a julgá-lo com bases críticas, além de ideológicas, filosóficas, políticas, etc.”, ao mesmo tempo em que propõe concentrar maior atenção em uma "perspectiva própria do século XX de raízes mais antigas: a educação literária como educação retórica" (BALBONI, 2006b, p. 6).

Portanto, a retórica é vista como uma possível chave para a análise discursiva dos textos, seja no âmbito argumentativo, seja no âmbito estético. Como se sabe, um texto literário usa imagens para persuadir, por isso é dito figurativo. As figuras revestem os temas utilizando-se, basicamente, da metáfora e da metonímia - ou seja, duas figuras de linguagem (ou de retórica).

Além disso, para dotar o texto de coerência semântica, o sujeito da enunciação ${ }^{100}$ instaura isotopias temáticas (aquelas que nos permitem generalizar o argumento do discurso e dizer que o texto fala "disso" ou "daquilo") e figurativas (verificáveis, sobretudo, na

\footnotetext{
${ }^{99}$ Perelman e Olbrechts-Tyteca definem uma teoria da argumentação como o "estudo das técnicas discursivas que permitem provocar ou aumentar a adesão dos espíritos às teses apresentadas à sua aprovação". PERELMAN, C; OLBRECHTS-TYTECA, L. Traité de l'argumentation. La nouvelle réthorique. Bruxelles: Éditons de 1'Univ. de Bruxelles, 1970, p.59. apud BARROS, 2001. p.109.

${ }^{100}$ Cf. nota 14 .
} 
recorrência metafórica e metonímica). Mais uma vez, portanto, é preciso dar crédito a outras linhas de análise:

Não basta, no entanto, estabelecer-se a existência de diferentes planos isotópicos; é preciso explicá-los e relacioná-los uns com os outros e com os planos temáticos e narrativos. Para tanto, podem-se convocar recursos dos estudos de retórica, de estilística e de poética (BARROS, 2002, p. 128-129).

A didatização da ópera satisfará, portanto, as três etapas do percurso gerativo de sentidos. No nível dito fundamental, a análise versará os afetos, os sentimentos das personagens transmitidos essencialmente pela música e pela representação cênica. O objetivo

principal será detectar o que acomete o sujeito. Sequencialmente, a tarefa será desvendar a trama, de modo que o aluno descobrirá por que o sujeito se encontra em tal estado. Ao final do percurso, tentaremos explicar como ocorreu a manipulação do destinador sobre o sujeito/destinatário, recorrendo ao próprio discurso.

\subsubsection{A abordagem social-histórica}

A didatização da ópera prevê também a adoção de uma metodologia que relacione o objeto com o seu contexto social-histórico, já que disso depende a coerência do próprio texto (BARROS, 2002).

Nesse sentido, é necessário proceder no projeto de explicação dos vínculos que prendem o discurso a suas condições histórico-sociais de produção e de recepção, pela análise mais acurada da enunciação.

Como vimos, o enunciador deixa "marcas" da enunciação no enunciado a partir das reações do ser vivo ao seu contexto. Assim, os estados eufóricos e disfóricos, convertidos em relações ideológicas dos sujeitos com os objetos de valor ou com outros sujeitos, convertemse, finalmente, em figuras e temas essencialmente predefinidos por um destinador socialhistórico. 
Por sua vez, o destinador social-histórico pressupõe um receptor-interpretante no papel do destinador-julgador, o qual deverá apreciar o texto a partir de um código cultural implícito.

Além disso, sabemos que, a partir da caracterização social-histórica do enunciador, é possível chegar a elementos externos ao texto, ou seja, a relações intertextuais. Assim, "a análise de outros textos, que formam o contexto do discurso em exame, permite alcançar os fatores sócio-históricos constitutivos da enunciação" (BARROS, 2002, p. 143).

No caso da ópera, é totalmente imprescindível inserir o objeto no seu contexto de produção e recepção que, deliberadamente, fundamentou a sua existência e sobrevivência. Não se poderá, contudo, desviar do foco textual. Ao contrário, a ideia é que o contexto socialhistórico seja um aliado na persuasão do enunciatário atual.

\subsection{OBJETIVOS}

"Fixar objetivos sem se referir às metas gerais equivale a impor ao
discente as necessidades da sociedade e dos sistemas produtivos;
equivale, pasolinianamente, a 'homologá-lo', fazendo dele um
moderno Caliban a serviço de um Próspero da era tecnológica."101

Freddi

Em um curso de língua estrangeira, as metas verticalizam a proposta de ensino e norteiam todo o seu percurso, o qual pode ser ilustrado por uma linha horizontal repleta de objetivos. As metas permitem que vislumbremos a cadeia dos objetivos e, ao mesmo tempo, evitam que a proposta de ensino se desvirtue em função de objetivos impróprios ou, até mesmo, contrários à proposta inicial.

As metas seriam abstratas e contemplativas, e atenderiam a uma concepção ideal do curso (v. cap. 1), ao passo que os objetivos, conteúdos amorfos que se formam a partir das metas, podem ser definidos como etapas concretas de realização. Haja vista a relação de interdependência entre ambos, é preciso criar uma interface entre as metas almejadas e os objetivos a serem propostos, no sentido de dar forma ao conteúdo. De outro modo, seria muito

\footnotetext{
101 "Fissare degli obiettivi senza riferirsi alle mete generali equivale a imporre al discente i bisogni della societá e dei sistemi produttivi; equivale pasolinianamente a «omologarlo», facendone un moderno Calibano al servizio di un Prospero dell'era tecnologica." Freddi.
} 
fácil recair na equação metonímica do abstrato (metas culturais) pelo concreto (objetivos estritamente gramaticais), como é o caso do material literário utilizado como pretexto para se ensinar pura gramática.

Portanto, diante de um objeto literário, os objetivos não podem versar a gramática da língua, senão para explicar e elucidar o próprio objeto. É preciso formular objetivos claros e precisos que incidam sobre a gramática do texto, ou seja, sobre a caracterização das personagens, as relações actanciais, as funções do narrador, o tempo e o espaço, enfim, todas as questões que envolvem o que é imanente no texto ${ }^{102}$.

Entretanto, não seria o caso de aposentar os preceitos da Educação Linguistica ${ }^{103} \mathrm{em}$ prol de uma educação exclusivamente literária, visto que as metas linguisticas, bem como os objetivos didáticos linguisticos, podem integrar perfeitamente a proposta de ensino sobre o objeto lírico. Seria o caso, então, de fundir ambos os princípios em favor de uma Educação Linguistico-Literária, que abranja tanto as metas culturais quanto as metas linguísticas configuradas no estudo sobre a gramática do texto.

Desse modo, ampliaremos o conceito das metas formativas, que resguardam não apenas a formação do indivíduo, como também a formação do falante de língua estrangeira, para quem também estão previstas as capacidades de compreender e interpretar os textos literários, adquirindo maior autonomia linguistica, comunicativa e interpretativa.

Com relação ao ensino da ópera, podemos estabelecer, de antemão, quais seriam os objetivos didáticos gerais e específicos a serem propostos num curso de italiano para estrangeiros.

Porém, antes de avançar, é importante classificar os objetivos em três categorias distintas, a saber: objetivos cognitivos, de habilidades e de atitudes, de modo que possamos identificá-los como condições reais a serem exercitadas e aprendidas.

\footnotetext{
${ }^{102} \mathrm{O}$ conceito de imanência ocupa lugar privilegiado na teoria semiótica de linhagem europeia. Lançado mais incisivamente por L. Hjelmslev, o linguista de Copenhague propôs como imanente uma "linguística-linguística", que elaborasse internamente seus conceitos, evitando aplicar-lhe razões e argumentos exteriores (da sociologia, fisiologia, psicologia, filosofia), atitude que considerava transcendente. BEIVIDAS, W. Reflexões sobre o conceito de imanência em semiótica Por uma epistemologia discursiva, In CASA - Cadernos de Semiótica Aplicada, Vol. 6, N. 2, 2008. Disponível no site da UNESP: Campus Araraquara, $<$ http://www.fclar.unesp.br/seer/index.php?journal=casa\&page=search\&op=titles\&searchPage=5 $>$. Último acesso em 5 dez 2009.

${ }^{103}$ O objeto da Educação Linguistica foi devidamente demonstrado no capítulo 1 deste trabalho.
} 
Ao definir o objetivo, em geral coloca-se ênfase em modificações de comportamento do aluno quanto a conhecimentos, habilidades e atitudes que, antes de cursar a referida disciplina, ele não era capaz de realizar, ou pelo menos de realizar tão eficazmente (MASETTO, 1997, p. 88).

Conhecer o drama, bem como interagir com suas linguagens, é o objetivo geral cognitivo do ensino da ópera, ao passo que compreender e interpretar o drama são objetivos gerais de habilidade. Valorar e criticar a obra, bem como seus aspectos peculiares, são objetivos de atitude. Os alunos deverão desenvolver, ao longo do percurso, práticas e estratégias para alcançar cada um deles.

Os objetivos específicos descendem diretamente dos objetivos gerais e concernem 1) à percepção e ao sentimento dos afetos na e pela música, 2) ao reconhecimento da trama e à associação dos afetos na caracterização das personagens e nas relações actanciais, 3) à identificação dos temas e das imagens e às questões de manipulação dos valores no e pelo discurso e 4) a aspectos contextuais e intertextuais da obra.

Para um melhor entendimento dos objetivos propostos como reflexo das metas formativas, é preciso recorrer à noção de "tarefa" (task), entendida como "uma atividade cujo objetivo não se limita à aprendizagem da língua estrangeira, prevendo, ao contrário, finalidades mais amplas que contribuem para uma formação integral do aluno" (SANTORO, 2007, p. 171).

Os alunos deverão descobrir, por meio das atividades propostas, o verdadeiro valor da ópera, e deverão ser capazes de assistir a um espetáculo como um nativo. Portanto, não teremos apenas o material autêntico, mas, igualmente, objetivos, atividades e resultados autênticos e concretos, aplicáveis também ao público nativo.

Assim, o autor do material autêntico deverá selecionar os elementos passíveis de análise e, a partir daí, formular tarefas que ativem a percepção dos alunos para a função de tais elementos na significação do objeto, incitando-os a apreender a gramática do texto e a refletir sobre ele.

Cabe aqui uma corajosa citação sobre o papel do professor nesse processo, muito diferente da figura (ainda vigente nos nossos dias) do tradicional professor de literatura.

Não é o professor onisciente e heterônomo da tradição que chega à aula com seu programa pré-confeccionado, estruturado, imodificável, centrado no corpus literário herdado por uma tradição preguiçosa. É, ao contrário, um 
literato-educador que guia os alunos ao acostamento, ao prazer e à valoração da literatura nas suas valências primárias, enquanto portadora de valores de beleza, cultura e humanidade e enquanto especial código semióticofuncional. Ele é, em suma, um animador especialista, qualificado, sensível e dúctil que ativa nos alunos os mecanismos psicológicos, culturais e operacionais que thes permitem conhecer e apreciar as grandes vozes da literatura e [...] o legado que tais vozes acumularam à posteridade (FREDDI, 2003, p. 61).

Portanto, desde que o professor esteja a par da relevância de cada tarefa, guiará os alunos no cumprimento dos objetos de forma interativa, dinâmica e abrangente, no seio de uma abordagem construtivista - lato sensu - e comunicativa ${ }^{104}$ de ensino-aprendizagem de língua estrangeira.

\subsection{O PÚBLICO}

A priori, o material operístico pode ser didatizado tendo em vista as necessidades de qualquer público de língua estrangeira, sendo funcional desde a primeira aula de um curso LE. O ideal é que seja inserido gradativamente desde o início do percurso, seja com relação à extensão, seja com relação à intensão do conteúdo.

Para um público A1, o contato com a ópera poderá se configurar apenas (ou praticamente apenas) no plano da emoção, o que nos permite desconsiderar totalmente (ou em grande parte) a complexidade da língua. Isso porque os objetivos, nessa fase, certamente não resguardarão a fundo a compreensão e interpretação de uma ária ou de um melodrama, mas com certeza poderão adentrar no jogo dos afetos e transportar os alunos para a atmosfera da música e da encenação, constituindo, ainda sim, um aspecto essencial do ensinoaprendizagem LE, haja vista a pressuposição de que "a emoção atue um papel fundamental no processo cognitivo" (BALBONI, 2006b, p. 9).

A partir do público A2, já é possível didatizar a ópera também no plano da razão, dosando a quantidade de input necessário a satisfazer os objetivos didáticos de determinado

104 Para tanto, as atividades deverão visar à abertura do canal comunicativo, no sentido de instaurar debates e discussões sobre o objeto. Isso nos permitirá alcançar uma meta linguistica de suma importância para a aquisição da língua estrangeira, que é a de praticar e produzir língua autêntica, em um contexto também autêntico. 
nível e cuidando sempre para que a complexidade da língua não seja um obstáculo na compreensão e interpretação do conteúdo.

Por fim, já a partir de um nível B1, os objetivos didáticos poderão requerer a compreensão e interpretação de todo um melodrama, como veremos no capítulo que se segue.

\subsection{A ORGANIZAÇÃO DO CORPUS}

A ópera pode ser considerada um material muito funcional para o trabalho em classe do ponto de vista organizacional. De fato, sua divisão em cenas já nos permite estabelecer, de antemão, uma disposição sucessiva de unidades mínimas de significado a serem didatizadas. Do mesmo modo, a reunião de várias cenas, formando um ato, estabelece uma nova divisão em unidades maiores. Por fim, o conjunto dos atos configura a unidade global da ópera.

Cada cena constitui em si uma unidade de sentido que, embora sua importância para o todo seja relativa, torna-se indispensável para uma leitura desvelada, seja no nível literário, seja no nível estético da ópera. Portanto, o ideal será trabalhar todas as cenas da ópera, ou a obra sem recortes, de modo a manter e transmitir ao aluno sua integridade de sentido.

É importante ressalvar, porém, que a restrição de integridade deve atender aos objetivos de compreensão e interpretação de uma ópera completa (v. Objetivos Gerais e Específicos neste mesmo capítulo), de modo que, no caso de objetivos menos abrangentes ${ }^{105}$, como os formulados por Balboni no seu livro Ensinar a literatura italiana a estrangeiros (2006), é possível considerar a totalidade de sentido de uma única cena operística e, ainda assim, desenvolver tarefas que trabalhem aspectos relativos à gramática do texto sem adentrar nos aspectos gerais da obra.

Entretanto, para nós, será essencial tomar cada cena operística por um input a ser aprendido pelo aluno, para que ele construa o contexto passo a passo e tenha uma visão de conjunto da obra. Assim, ele também poderá voltar a pontos anteriores para colher elementos importantes para a compreensão e interpretação do drama.

\footnotetext{
${ }^{105}$ Os objetos estipulados por Balboni referem-se à caracterização de personagens, às descrições objetiva e subjetiva de um trecho literário, ao estudo das figuras de linguagem, dos versos, das rimas e do ritmo de poesias, etc.
} 
Cada cena será didatizada seguindo as fases de uma unidade de aprendizagem, a saber: globalidade, análise, verificação e síntese (FREDDI, 1979).

$\mathrm{Na}$ fase de globalidade, o aluno entrará em contato com a cena três vezes. Essa fase virá acompanhada de específicas atividades antes, durante e depois de cada contato, de modo que o aluno penetre na cena passando da globalidade a uma compreensão cada vez mais detalhada.

Na fase de análise, as tarefas atuarão diretamente sobre a compreensão e interpretação textual, com técnicas didáticas que incitem os alunos a refletirem sobre o sentido da cena nos níveis linguístico e analítico.

Ao final de cada ato, o conteúdo geral das cenas deverá ser retomado na forma de síntese, guiando os alunos na reflexão sobre a totalidade do sentido do ato, além de verificar o nível de compreensão de cada aluno.

Se as cenas constituem unidades de aprendizagem, o conjunto dos atos de uma ópera compõe uma unidade didática, ao final da qual se chegará a uma síntese conclusiva sobre o sentido da obra.

Como uma unidade didática, o ensino da ópera será precedido por uma fase de motivação que deverá introduzir o tema principal do drama. Essa fase pode ser uma unidade de aprendizagem ou apenas uma atividade que coloque em evidência o cerne da ópera, de modo a criar uma motivação de fundo válida para todo o percurso da unidade didática.

Além disso, é interessante integrar ao estudo do melodrama tarefas complementares que deem conta do contexto social-histórico da obra, que, como vimos, também é responsável por sua coerência de sentido.

\subsection{AS TÉCNICAS DIDÁTICAS}

No curso que proponho, três coisas diferenciam o aluno de um real espectador de ópera. A primeira delas é a existência de uma apostila didática repleta de tarefas a serem executadas antes, durante e depois de cada contato com o objeto. A segunda é a presença de 
um professor, ou melhor, um guia, que o ajudará a executá-las da melhor maneira possível, e a terceira são seus colegas de curso, com os quais compartilhará a incumbência de realizar cada tarefa, sempre em grupo e colaborando entre si.

Para que o professor seja, de fato, apenas um guia, para que os alunos consigam realizar as tarefas de modo cooperativo e com o filtro afetivo baixo, e para que a compreensão se dê com eficácia, as técnicas didáticas devem dar conta de ativar nos alunos as estratégias cognitivas de que já falamos e devem atuar tanto no plano linguístico quanto no plano de análise, como veremos a seguir.

Técnicas de motivação:

- Brainstorming: a "tempestade cerebral" consiste em uma atividade exploratória da capacidade criativa de cada indivíduo acerca de determinado campo semântico. A partir de uma palavra-chave (relativa ao tema principal da ópera) os alunos deverão relacionar conceitos ou ideias afins, com o objetivo de entrar no tema.

- Transcodificação visual: a partir de algumas imagens do espetáculo, os alunos tentarão adivinhar o(s) tema(s), a época e o local em que a história se passa, bem como a relação entre os personagens.

- _Transcodificação sonora: consiste em fazer ouvir a melodia (sem voz) e relatar as impressões, ou imaginar uma cena para aquela música. O objetivo desta técnica é ativar a compreensão a partir da emoção e dos afetos. É ideal para a abertura.

- _Formulação de hipóteses: é uma técnica de motivação que deve ser utilizada quando se há o contexto construído. Por exemplo, o aluno deve formular hipóteses acerca da reação de determinado personagem diante de um fato conhecido com base no seu caráter.

Técnicas para a 1ํ- visão da cena: Após um primeiro contato com a cena, os alunos deverão praticar uma das duas técnicas abaixo:

-_Confronto com os colegas: os alunos deverão discutir com seus colegas de grupo sobre o que entenderam. Neste caso, os alunos não precisarão escrever o que entenderam, mas apenas trocar informações com seus colegas sobre o conteúdo musical, cênico e, eventualmente, textual apreendido. Por ser uma técnica muito recorrente e de realização oral, não deverá aparecer como atividade, bastando que o professor comande a sua realização. 
- _Relato das impressões: substitui a técnica acima. Após a primeira visão da cena, o aluno deve escrever suas impressões sobre o que foi visto e ouvido, levando em consideração tudo o que compõe a cena. O objetivo desta técnica também é ativar a compreensão a partir da emoção e dos afetos, mas, desta vez, fazendo com que os alunos primeiro formulem individualmente as suas impressões e, apenas depois, compartilhem-nas com seus colegas. Ao contrário da técnica anterior, o relato das impressões deve entrar como atividade no corpo da apostila.

Técnicas para a 2a visão da cena: Após a visão da primeira cena e o confronto de informações com os colegas, o professor já indicará a(s) atividade(s) a ser(em) realizada(s) após a visão da segunda cena.

- _Descrição: a descrição das cenas também será feita a partir dos afetos apreendidos pela música e pela encenação dos atores, mas, desta vez, enriquecida com a inclusão do texto escrito (legenda).

- _Descrição parcial: pedir ao aluno que descreva a reação (eufórica ou disfórica) de um personagem diante de um fato já conhecido. Indicada para as árias ou cenas com cantábile, em que há maior expressão sentimental.

- _Pergunta aberta de tipo hipotético: pergunta-se diretamente sobre um evento cênico. Porém, é importante que a pergunta não implique uma necessária compreensão da fala - evitando, assim, que o filtro afetivo do aluno levante. Por isso, para esta fase são mais indicadas as perguntas de tipo hipotético que se refiram à entrada de um novo personagem, ao estado de ânimo de alguém, às mudanças de melodia, ou, ainda, perguntas gerais sobre o que estariam falando as personagens ou por que estariam discutindo $\mathrm{o}_{2}$ etc. Certamente, para responder às perguntas desta fase, os alunos se valerão muito do contexto construído até então e lançarão hipóteses.

- _Completamento: consiste em inserir as palavras que faltam em um texto. Nesta fase, as palavras retiradas devem ser de muito fácil compreensão. Trata-se de uma clássica técnica de compreensão oral muito recorrente na didatização de canções. Para realizá-la, os alunos deverão ver a cena sem a legenda.

- Completamento facilitado: a mesma técnica acima referida com as palavras a serem inseridas dispostas em desordem fora do texto. A vantagem desta técnica sobre a anterior é a facilitação da compreensão oral por meio de uma "compensação" na 
habilidade de compreensão escrita. Para realizá-la, os alunos deverão ver a cena sem a legenda.

- Tabela: nas cenas de conjunto, especialmente naquelas em que os vários personagens denotam afetos diferentes, os alunos deverão completar numa tabela com os nomes dos personagens o sentimento de cada um. Seu objetivo é a percepção e distinção entre os vários tipos de afetos reunidos em uma única cena. Ideal para as cenas de concertato.

- CCorrespondência: consiste em discriminar a(s) fala(s) de cada personagem da cena e ligá-la(s) ao seu respectivo locutor. Também é indicada para as cenas com três ou mais personagens.

Técnicas de compreensão escrita (libreto): Após a segunda visão da cena, os alunos deverão realizar atividades que levem à compreensão escrita do libreto.

- _Cloze parafrástico: os alunos devem completar a paráfrase da cena com palavras de sentido equivalente. A paráfrase pode ser em versos ou escrita em discurso indireto.

- _Cloze parafrástico facilitado: a mesma técnica com as palavras dispostas em ordem aleatória fora do texto.

- _Múltipla escolha: a partir de um verso no original, dispõem-se várias paráfrases de sentido não-equivalente em meio a uma única paráfrase de sentido equivalente.

- Verdadeiro ou falso: os alunos deverão julgar as paráfrases de sentido equivalente como afirmações verdadeiras, e as de sentido não-equivalente como falsas.

- Encontrar os versos: a partir de várias paráfrases de sentido equivalente, os alunos deverão encontrar, na cena em questão, os versos que lhes correspondem.

- Atualização linguística: consiste na tradução de algumas palavras arcaicas ou de uso especificamente literário a partir do contexto da cena. As palavras a serem traduzidas devem estar evidenciadas no texto.

- _Atualização linguística facilitada: a mesma técnica com as palavras traduzidas dispostas em ordem aleatória fora do texto.

- Atualização de diálogo aberto: apresentam-se as falas parafraseadas de um personagem para que os alunos completem o diálogo parafraseando as falas do 
outro personagem. Além de requerer um esforço no sentido de atualizar a língua, esta técnica prevê a utilização de estratégias relacionadas à coerência global e coesão textual.

- _Definição de vocábulos: dispõem-se de um lado algumas palavras do texto original e, de outro, suas acepções contextuais, retiradas de um dicionário, em ordem aleatória, para que os alunos façam a correspondência a partir do contexto.

- Comentar versos: os alunos devem comentar um dos versos contido na cena não apenas com base na sua compreensão escrita, como também na sua interpretação pessoal. Por isso, os versos escolhidos devem demandar inferências e conter os elementos passíveis de análise semiótica, como as categorias de tempo e espaço, as relações entre sujeito e objeto, etc.

- _Divisão do texto em partes: esta técnica deverá ser utilizada quando uma ária ou uma cena de conjunto apresentar duas ou mais seções argumentativas. Os alunos deverão segmentar o texto em diversas partes de acordo com os diferentes temas propostos e justificar sua ação.

- _Explicar a cena: assim como na técnica acima, a explicação da cena sugere que os alunos transponham a paráfrase e adentrem na análise textual.

- _Pergunta aberta: perguntas referenciais e/ou inferenciais relativas ao conteúdo da cena. É sempre interessante pedir aos alunos que colham elementos do texto para comprovar suas ideias.

Técnica de fim de ato:

- Reordenação de parágrafos: consiste em apresentar um texto em prosa, parafraseando todas as cenas de um ato do libreto, com os parágrafos em ordem casual. Funciona como uma síntese do percurso, além de trabalhar a coerência textual e os indicadores metacomunicativos ("em primeiro lugar", "além disso", “enfim”, etc). É sempre importante que o primeiro parágrafo já venha numerado, funcionando como ponto de partida e apoio para os alunos.

Técnicas específicas de análise e de contexto social-histórico:

- Interdiscursividade: reportam-se várias passagens discursivas de um mesmo personagem para que se estabeleça a sua posição em relação ao tema proposto, a sua visão de mundo e, enfim, a sua caracterização como ser autônomo por meio do 
seu discurso. Para tanto, os alunos deverão individuar as isotopias semânticas nas várias passagens.

- _Intertextualidade: a mesma técnica acima referida com passagens de outras obras.

É preciso sublinhar que cada cena impele à utilização de uma determinada técnica quase que naturalmente, de modo que não se deve "forçar" a acomodação de uma cena a uma técnica pelo simples fato de querê-la usar. O ideal é que se didatizem as cenas a partir do seu estilo: uma cena com sintaxe e léxicos difíceis levará certamente a uma técnica de paráfrase indutiva, assim como um verso metafórico levará a uma pergunta inferencial, uma cena com muitos elementos visuais levará à descrição $o_{2}$ e assim por diante.

\subsection{AVALIAÇÃO}

Entende-se por avaliação a prática de medir a produção do aluno com base em critérios e parâmetros estabelecidos durante a fase de formulação dos objetivos gerais e específicos da unidade didática.

A avaliação é feita durante o cumprimento das tarefas e, eventualmente, também durante um teste formal, que pode ser realizado de inúmeras maneiras, dentro ou fora da sala de aula.

Na verdade, a avaliação acompanha todo o processo de aprendizagem e não só um momento privilegiado (o da prova ou do teste), pois é um instrumento de feedback contínuo para o educando e para todos os participantes. Nesse sentido, fala da consecução ou não dos objetivos da aprendizagem (MASETTO, 1997, p. 98).

A prova, no entanto, consente o registro das informações relativas ao desempenho do aluno, o que permitirá um diálogo mais objetivo com seus colegas e com o próprio professor. E a nota, como símbolo de conclusão de uma etapa do processo de aprendizagem, "só tem valor se conseguir representar em código a aprendizagem realizada" (MASETTO, 1997, p. 99). 
Para verificar a aprendizagem, é necessário recorrer a determinadas técnicas avaliativas, tendo sempre em vista o objetivo a ser examinado. No caso da ópera, os objetivos cognitivos poderão ser testados 1) pela própria consecução progressiva das atividades, 2) com exercícios que exigem um conhecimento prévio do input, como aqueles que retomam os temas, o enredo, ou que colaboram para a construção de um tema ou de um personagem, e 3) pela realização de uma prova ao final do percurso.

Os objetivos de habilidades, por sua vez, poderão ser testados a partir de uma prova prática, como a organização de ida ao teatro para ver o próprio espetáculo estudado ou a visão ininterrupta do DVD.

Por fim, os objetivos de atitude poderão ser testados a partir de debates e questionários que denotem a valoração do objeto.

Ao contrário do que se pensa, a avaliação não diz respeito apenas ao sucesso do aluno, e considera também "a eficácia do material didático utilizado, a adequação do ritmo de curso proposto, a aderência entre a metodologia adotada e as finalidades, as motivações e as características sócio-culturais dos alunos, e assim por diante" (BALBONI, 2006a, p. 125).

Por fim, a avaliação pode ser feita também pelo próprio aluno, que pode avaliar o curso e se autoavaliar com base nos mesmos critérios adotados pelo docente. Nesse caso, é possível que o aluno também (re)avalie o seu desempenho como aluno/falante de língua estrangeira e sua posição autônoma diante da língua e da cultura alvo. 


\section{O CURSO "RIGOLETTO: PER GLI AMANTI DELLA LINGUA E DELLA CULTURA ITALIANA"}

A fim de colocar em prática toda a teoria desenvolvida nos quatro primeiros capítulos deste estudo e, assim, verificar a eficácia do material operístico, didatizei a ópera Rigoletto, de Giuseppe Verdi e Francesco Maria Piave, escrita em 1851 durante o período Romântico da Ópera italiana.

Esse material constituiu a primeira versão do curso "Rigoletto: per gli amanti della lingua e della cultura italiana", promovido pelo Departamento de Letras Modernas - Área de Língua e Literatura Italiana - e organizado pelo Centro de Cultura e Extensão da Universidade de São Paulo, com duração de doze horas e voltado para um público de língua italiana a partir do nível B1.

Às reflexões sobre os resultados obtidos a partir dessa primeira experiência somaramse as leituras mais aprofundadas sobre a Semiótica das Paixões e sobre a Didática de ensino em geral, e tudo isso contribuiu para a nova versão do curso "Rigoletto: per gli amanti della lingua e della cultura italiana", apresentada neste capítulo.

Antes de avançar, porém, é preciso esclarecer a função do referido curso no discurso sobre a inserção da ópera lírica no currículo LE. Em verdade, o curso aparece como uma proposta extracurricular, e assim o foi concebido, pela impossibilidade de se inserir uma unidade didática sobre uma ópera inteira nos cursos do Italiano no Campus ${ }^{106}$ ou em qualquer outro que siga um manual didático. Por outro lado, o curso se propõe como o protótipo ideal de didatização da ópera a ser incluído em um currículo também ideal ${ }^{107}$, dado que o recorte implica em uma nova edição, para além daquela prestada pelo diretor do espetáculo e, portanto, em uma nova impressão subjetiva sobre o trabalho dos autores.

\footnotetext{
${ }^{106}$ Refiro-me aos cursos de língua italiana oferecidos pelo Centro de Cultura e Extensão da Faculdade de Letras da USP.

107 Sem a pretensão de entrar no mérito da questão, talvez o currículo ideal seja aquele que não privilegie a progressão gramatical, mas a progressão de gêneros discursivos da língua estrangeira.
} 


\subsection{A ESCOLHA DA ÓPERA}

A escolha da ópera Rigoletto foi, primeiramente, uma resposta às questões surgidas após a didatização da ária "La donna è mobile", devido à curiosidade, tanto minha quanto dos alunos, em conhecer melhor o personagem dessa famosa ária verdiana.

É fato que "La donna è mobile" constitui uma unidade de sentido em si, podendo ser considerada uma ária universal. Uma análise intertextual mais acurada poderia, inclusive, corroborar uma leitura descontextualizada da ária, já que tantos poetas e autores de várias épocas compartilharam o conceito da "mulher volúvel", passando por nomes como Petrarca, Camões e Claudio Manuel da $\operatorname{Costa}^{108}$.

Por outro lado, tomando-se o sujeito da enunciação, o duque de Mântua, pelo autor do texto, reforça-se a ideia de um enunciador também universal, que reflete claramente as opiniões do próprio poeta sujeito da enunciação. Entretanto, na ópera de Verdi, esse personagem não pode ser lido pelo viés da poesia isolada porque constitui um ser autônomo dentro da ópera, o que nos coloca em posição diversa àquela adotada diante da leitura de muitas poesias. No nosso caso, é possível (re)conhecer o personagem por meio do seu discurso para além da ária, que representa apenas uma fatia dele.

Além disso, em La Traviata (1853), temos a contraversão da concepção do "ser volúvel", desta vez solucionado na figura masculina pelo verso "Sia pure ma volubile sovente è l'uom" 109 .

Em verdade, o novo verso de Piave traduz toda a ironia contida em Rigoletto, porque ao longo da ópera o espectador descobre que, na verdade, o próprio duque é retratado como uma pessoa volúvel. Além disso, esse verso evidencia uma técnica essencial na construção de qualquer texto, ou seja, o mecanismo de persuasão do enunciador que, dessa vez, inverteu voluntariamente um lugar comum para produzir o efeito de sentido desejado no enunciatário.

\footnotetext{
${ }^{108}$ Ver neste mesmo capítulo a atividade número 11 da primeira unidade de aprendizagem e Anexo B. 109 “Que seja, mas frequentemente volúvel é o homem”. O personagem Giorgio Germont está disposto a convencer a protagonista Violetta Valéry a não permanecer ao lado de seu jovem filho, e diante de suas hesitações profere esse verso. La Traviata, Ato II, cena I, tradução minha.
} 
No mais, Rigoletto é uma das melhores óperas de Giuseppe Verdi e quiçá do mundo. Nas palavras do próprio compositor, "o sujeito é grande, imenso, e possui um caráter que é uma das maiores criações de que se orgulha o teatro de todos os países e de todas as épocas". 110

O duque é apenas um coadjuvante e sua profundidade como personagem não pode ser comparada à de Rigoletto, seu bobo da corte. De acordo com Jorge Coli (2003, p.75), “o duque de Mântua, belo, brilhante, rico e poderoso, é um libertino banal".

Ao contrário, a caracterização de Rigoletto é muito mais profunda e humana, representa a síntese da alma de um desafortunado, de um desgraçado, tratado por Verdi com esmerada compreensão. Segundo Samaritani, Rigoletto significa "a solidão desesperada, a impossibilidade de resgate. Eu sinto que apenas a ele Verdi deu ênfase e apenas por ele possui adesões viscerais" 111 .

Enfim, o sujeito de Rigoletto é tão denso e significativo que até mesmo a língua do século XIX deixa de ser um entrave na compreensão e interpretação do drama. O espectador se envolve de tal maneira com o drama do bufão que se torna impossível não entendê-lo, não compreendê-lo, não compartilhar suas dores e seus afetos!

Por questões didáticas, para o curso "Rigoletto: per gli amanti della lingua e della cultura italiana" utilizaremos o filme de Jean-Pierre Ponnelle, com as vozes de Luciano Pavarotti (Duque de Mântua), Ingvar Wixell (Rigoletto) e Edita Gruberova (Gilda) nos papéis principais, e regência do maestro Riccardo Chailly. Isso pode parecer irônico, pois se trata de uma adaptação para o cinema. Entretanto, a proposta não fere o conceito de material autêntico que adotamos neste trabalho, visto que o DVD foi produzido para o público em geral, e não manipulado para fins didáticos ${ }^{112}$.

De fato, o filme de Jean-Pierre permitiria ao aluno usufruir de todas as vantagens do cinema relativas à construção dos efeitos de verdade na narrativa, como o próprio local das filmagens, no castelo de Mântua, além de todos os efeitos de realidade provindos de uma

\footnotetext{
110 "Il sogetto è grande, immenso, ed avvi un carattere che è una delle più grandi creazioni che vanti il teatro di tutti i paesi e di tutte le epoche (tradução minha). SEGRETO, V. R. La genesi di Rigoletto - Un viaggio nell'epistolario verdiano. In: Teatro Regio di Parma. Website da instituição. Disponível em:

$<$ http://www.teatroregioparma.org>. Acesso em: jun 2009.

111 "Rigoletto: la solitudine disperata, l'impossibilità di riscatto. Io sento che solo su Rigoletto Verdi ha posto l'accento e solo per lui ha delle adesioni viscerali' (tradução minha). SAMARITANI, P. L. Rigoletto. [S.l: s.d.],p.1. In: TEATRO Regio di Parma. Website da instituição. Disponível em: $<$ http://www.teatroregioparma.org $>$. Acesso em: jun de 2009.

112 O DVD utilizado no curso "Rigoletto: per gli amanti della lingua e della cultura italiana" encontra-se disponível na biblioteca da Escola de Comunicação e Artes (ECA) da Universidade de São Paulo, localizável pelo código ECA SMM/DVD0224.
} 
gravação externa, como o vento que faz balançar as folhas das árvores, o fumo, os reflexos, etc. Sobretudo o desempenho dos atores, que não precisam olhar para o maestro enquanto cantam e podem se movimentar com maior liberdade, sem medo de prejudicar a performance vocal, pode ser considerado uma motivação didática.

\subsection{A ANÁLISE DE RIGOLETTO, DE GIUSEPPE VERDI}

Rigoletto é o personagem principal do drama de Giuseppe Verdi, inspirado na peça Le rois s'amuse, de Victor Hugo, datada de 1832.

Verdi teve que modificar as personagens, o tempo e o espaço da narrativa para escapar de uma censura que não permitia expor a figura régia ao ridículo, já que grande parte da Itália se encontrava sob o domínio austro-húngaro. Era, portanto, extremamente necessário evitar tudo o que pudesse se relacionar com a decadência da aristocracia austríaca e reforçar o movimento da unificação e independência italianas.

Afinal, ele não podia arriscar ter a mesma sorte de Victor Hugo, que vira seu Le rois s'amuse proibido na França logo após sua estreia e banido dos palcos parisienses por cinquenta anos, retornando apenas sob a forma da famosíssima ópera Rigoletto.

Por isso, Verdi preferiu revestir o tema do antagonista com a figura de um duque, o Duque de Mântua, de modo que "Il Re Francesco non vi è che storicamente dipinto"113. A título de facilitar a análise, segue abaixo a sinopse de Rigoletto $^{114}$ :

\section{Ato I}

\footnotetext{
113 "O Rei Francisco só aparece historicamente pintado" (tradução minha). Esta frase é de Francesco Maria Piave, o libretista de Rigoletto, em carta de 15 de agosto de 1850 a Carlo Marzari, presidente do Teatro La Fenice, de Veneza. Na época, Verdi havia encarregado Piave de livrar o projeto da intervenção da Censura. SEGRETO, V. R. La genesi di Rigoletto - Un viaggio nell'epistolario verdiano. [S.1: s.d.], p.6 In: Teatro Regio di Parma. Website da instituição. Disponível em: < http:// www.teatroregioparma.org/stagionelirica2005/rigoletto/rigoletto_saggi.htm>. Acesso em: ago 2008.

${ }^{114}$ Esta sinopse encontra-se em: WIKIPÉDIA. Enciclopédia virtual. Disponível em:

$<$ http://pt.wikipedia.org/wiki/Rigoletto>. Acesso em: mai 2009.
} 


\section{Parte I - Salão do palácio do Duque de Mântua}

No palácio do Duque de Mântua acontece um baile. A música preenche o salão. O Duque conversa alegremente sobre suas aventuras e conquistas amorosas com o cortesão Borsa. Fala, em especial, da sua mais recente aventura: há três meses, uma bela jovem é observada por ele. Mas, até aquele momento, a oportunidade que teve de vê-la foi na igreja, mas ela ignora quem ele seja. O Duque conta que ela mora em uma pequena vila, e que um homem desconhecido a visita todas as noites. Entre os convidados estão o Conde e a Condessa de Ceprano. O Duque se encanta com a beleza da Condessa e canta sobre seus amores momentâneos. De um lado, o Duque faz reverências à beleza da Condessa, de outro, o Conde, seu marido, é ridicularizado por Rigoletto, que acaba de entrar. Em seguida entra Marullo, que reúne outros cortesãos para contar um grande segredo: o corcunda Rigoletto, o bobo da corte, tem uma amante! A gargalhada é geral entre todos os presentes. O Duque e Rigoletto retornam. Na presença de Ceprano, Rigoletto insinua maneiras pelas quais o Duque poderia afastar o Conde e, assim, seduzir sua esposa. Quando Rigoletto chega a ponto de sugerir que o Conde fosse executado, Ceprano embravece num impulso de desafiá-lo para um duelo. Outros cortesãos demonstram repúdio e desprezo pelo repugnante e debochado Rigoletto. O Duque, nesse momento, mostra-se irritado. De repente, surge Monterone, que acusa energicamente o Duque de ter desonrado sua filha. Rigoletto, em uma atitude desprezível, faz zombaria do infeliz homem, imitando Monterone. Este mostra revolta e amaldiçoa Rigoletto pela atitude indigna, ao rir da mágoa de um pai. Rigoletto, nesse momento, se mostra perturbado e com medo. Todos ficam irritados com Monterone, por ter acabado com a festa.

\section{Parte II - É noite. Beco escuro entre a casa de Ceprano e Rigoletto.}

Rigoletto recorda a maldição de Monterone com uma estranha sensação, talvez um mau pressentimento. Aproxima-se Sparafucile, oferecendo seus serviços como assassino profissional. Suas vítimas são atraídas à sua casa por sua irmã, Maddalena. Rigoletto recusa tais serviços, mas aquele encontro faz com que ele reflita. Só, Rigoletto recorda sua vida, as humilhações pelas quais já passou por ser aleijado e bobo da corte. Pensa, então, em sua filha, Gilda, única pessoa no mundo capaz de solicitar sua face terna e humana. O bufão vai para casa perdido em pensamentos e encontra Gilda. Ela lhe pede para contar sobre o seu passado, deseja saber o nome da sua mãe. Rigoletto fala das suas desgraças e do amor perdido. Diz, ainda, que ela é sua única alegria. Energicamente, proibe-lhe de sair de casa desacompanhada e reforça o pedido à governanta. Pede a Giovanna que esteja sempre atenta à filha. Rigoletto 
sai e, sem ser visto, o Duque chega. Suborna Giovanna para deixá-lo entrar. Gilda encontra-se apaixonada pelo Duque, que é belo e jovem e que ela acredita ingenuamente ser um estudante. Gilda nada contou ao pai sobre essa paixão. Nesse encontro, o Duque faz juras de amor. Gilda está encantada e indefesa pelo amor. Ouvem-se os passos de Ceprano e dos outros.

O Duque, que receia ser descoberto, pensa em fugir. No escuro, Ceprano, Marullo e outros cortesãos se encontram com o objetivo de raptar a suposta amante de Rigoletto. Rigoletto chega e pensa que quem está sendo levada é a Condessa de Ceprano. Ele participa da ação com os olhos vendados, ajudando a segurar a escada.

Quando partem, Rigoletto tira a venda dos olhos. É tarde. Lembra angustiado da maldição de Monterone.

\section{Ato II}

\section{Palácio do Duque}

O ato inicia com o Duque desolado por não ter notícia do seu anjo. Descobre, então, que Gilda foi raptada. Entra em desespero; deseja encontrá-la para confortá-la. Os cortesãos, com sabor de vitória, contam-lhe como prenderam a amante do corcunda, e lhe entregam Gilda. Rigoletto aparece demonstrando indiferença, mas no seu íntimo reina um enorme desespero para encontrar sua filha. Sem querer, com a chegada de um pajem, ele descobre que o Duque está com Gilda. Totalmente fora de si, Rigoletto tenta forçar seu caminho até o Duque. Mas ele é afastado pelos cortesãos e, nesse momento, roga para que ela seja liberta. Gilda, em lágrimas, é trazida até o pai. Gilda diz ao pai que o Duque lhe tirou a honra e cofessa que já o conhecia. Monterone, ao ser conduzido à prisão, esbraveja contra a impunidade do Duque. Entretanto, Rigoletto jura que haverá, sim, uma vingança. Sente-se obstinado, não obstante as súplicas de Gilda pedindo perdão ao Duque.

\section{Ato III}

\section{Uma hospedaria afastada da cidade. É noite.}

Rigoletto, que havia pagado Sparafucile para assassinar o Duque, vai com Gilda até um ponto onde poderão observar tudo o que se passa dentro da casa. Gilda, ao longe, vê o Duque, disfarçado, indo ao encontro de mais uma de suas aventuras amorosas. O Duque canta cinicamente a canção que expressa seu desprezo pelas mulheres. Enquanto isso, Rigoletto e Sparafucile planejam o assassinato. Maddalena é chamada e flerta com o Duque. Gilda não tem como evitar a cena do Duque com Maddalena, pois é forçada a olhar. O Duque diverte-se com Maddalena, corteja-a. Gilda se amargura com as sombrias ameaças de Rigoletto e, por 
isso, prefere não seguir a ordem do pai de sair da cidade e se esconde. Rigoletto, no entanto, pensa que Gilda já foi e se afasta. Maddalena, com pena do jovem, tenta convencer Sparafucile a matar outra pessoa em vez do Duque. Ele se deixa persuadir e promete matar o primeiro que entrar pela porta e entregar o corpo ao mandante como se fosse do Duque. Gilda retorna, pois fica sabendo dos planos para o Duque e resolve se sacrificar pelo amado. Ela vai ao encontro de Sparafucile e é esfaqueada. O assassino e sua irmã escondem a vítima em um saco. Muito feliz por estar concretizando sua vingança, Rigoletto está ansioso por jogar o saco no rio, quando, para seu horror, ouve a voz do Duque ao longe cantarolando. Rigoletto abre o saco e vê sua filha agonizando. Ela lhe implora o perdão e morre. Rigoletto está transtornado e infeliz. Assim termina a trama, com a maldição de Monterone cumprida.

Voltando à análise, podemos dizer que Rigoletto é, de fato, um personagem complexo. Ele pertence à gama de personagens verdianos que superam seu estágio inicial de estereótipo por meio do sofrimento, da dor, da humilhação e da perda, para atingirem a plenitude de sua humanidade, alçando-se à condição de seres humanos complexos (COELHO, 2002).

Dada a sua condição social e seu aspecto físico (Rigoletto é o bufão da corte, corcunda e disforme), sua organização sintagmática pode ser descrita na forma modal /querer-ser, nãocrer-ser e saber-não-poder-ser/, produtora do efeito de sentido passional de amargura.

De fato, na ária "Cortigiani, vil razza dannata" $" 115$, percebemos uma intensa hostilidade de Rigoletto para com os "homens" e a "natureza", responsáveis por fazerem dele um ser "vil” e "perverso". Sua condição modal restringe-se a "não-dever" e "não-poder" fazer outra coisa senão "rir", já que "o legado de cada homem" tirou-lhe "o choro"! Por isso sente "tanta alegria" em "mordê-los", atormentá-los. Rigoletto é, de fato, um bufão que odeia "ser bufão" e "ser deforme".

\footnotetext{
115 "Pari siamo!... io la lingua, egli ha il pugnale; L'uomo son io che ride, ei quel che spegne!...

Quel vecchio maledivami!...

O uomini! O natura!....

Vil scellerato mi faceste voi...!

Oh rabbia!... esser difforme!... esser buffone!...

Non dover, non poter altro che ridere!...

Il retaggio d'ogni uom m'è tolto.... il pianto!...

(...)

Se iniquo son, per cagion vostra è solo...

(...)" Ato I, Cena VIII
}

Todas as traduções dos trechos da ópera são minhas. 
Temos, aqui, o jogo do ser e do parecer no tema do homem que parece vil e perverso, figurativizado no indivíduo de aparência repulsiva, exatamente como em $A$ bela e a fera e $O$ corcunda de Notre Dame. Assim como nos outros casos, Rigoletto adota a imagem de homem mau - cujo instrumento para ferir figurativiza-se na "língua" sarcástica que se assemelha ao "punhal" de um assassino - como uma arma contra a sua condição. Se ele não fosse mau, causaria apenas pena e compaixão nos outros, e se tornaria ainda mais vulnerável. Daí o verso "se sou iníquo, é só por culpa de vocês..."

Além disso, assim como nos outros casos, há um ser complementar a esse que é totalmente puro e bom (figurativizado no objeto de valor "mulher"), ao qual ele se apega desesperadamente para não virar totalmente mau. Como pai, Rigoletto modaliza-se em /querer-ser, crer-ser, saber-poder-ser e querer-fazer (bem)/ diante de seu objeto, o que produz o efeito passional de amor. A continuação dessa mesma ária explicita seu outro lado com o verso "Mas em outro homem aqui me transformo!..."."16, enunciado no momento em que Rigoletto entra em casa.

Com Gilda, seu "coração oprimido" encontra "só alegria". Toda a amargura que ele sente fora de casa dá lugar ao amor que sente pela filha, sua "vida", seu "único bem na Terra". Gilda não é apenas um objeto necessário para a manutenção da sua integridade, mas é seu único objeto de valor, sem o qual sua existência perderia completamente o sentido. Em Gilda, Rigoletto encontra o sentido de sua existência, e isso fica evidente quando ele lhe enuncia efusivamente "Meu universo está em você!"117.

A combinação de ambos os sentimentos causa a sensação de uma preocupação permanente, dando origem a um constante estado de tensão. Rigoletto /deve/ proteger Gilda porque ele /não pode/ ficar sem ela. A proteção excessiva de Rigoletto se agrava com a maldição de Monterone, que o leva a reiterar a ordem de Gilda permanecer em casa à governanta com a ária "Veglia, o donna, questo fiore". 118

\footnotetext{
116 "Ma in altr'uom qui mi cangio!..."

117 "Il mio universo è in te". Ato I - Cena IX.

118 "Veglia, o donna, questo fiore

Che a te puro confidai

Veglia attenta, e non sia mai

Che s'offuschi il suo candor.

Tu dei venti dal furore

Ch'altri fiori hanno piegato

Lo difendi, e immacolato

Lo ridona al genitor". Ato I - Cena X.
} 
Nessa ária, percebemos que o valor de Gilda é a sua pureza, figurativizada na "flor pura", "cândida" e "imaculada" que deve ser protegida do "furor dos ventos" que curvaram outras flores. Rigoletto sofre porque sabe que o valor de Gilda é constantemente ameaçado pelos actantes que adorariam seduzi-la, ou mesmo raptá-la, ainda mais se descobrissem que ela é filha do bufão que os ridiculariza todo o tempo.

Particularmente interessante é a duração da cena com Gilda, chamada pelo próprio Verdi "cena eterna"119. A cena é, de fato, muito longa (somando-se ao dueto com Gilda, dura $11 \min 24 \mathrm{~s}$ no filme). Além disso, Rigoletto parte por um instante, mas retorna e continua a implorar o cuidado da governanta, o que deixa o Duque impaciente. Essa extensão denota o alto grau de tensividade-fórica que une o sujeito a seu objeto, traduzido em preocupação e medo de cisão (“Quanto afeto!... quanto cuidado! / O que teme, meu pai?"120).

Os outros sujeitos da ópera também possuem objetos de valores figurativizados na "mulher", como podemos observar na tabela abaixo:

\begin{tabular}{ll}
\hline Sujeito & Objeto \\
\hline Duque de Mântua & Mulheres em geral \\
Conde de Ceprano & Condessa de Ceprano \\
Monterone & Filha \\
Sparafucile & Maddalena \\
\hline
\end{tabular}

Tabela 1. Os sujeitos de Rigoletto e seus objetos de desejo

Entretanto, à diferença de Rigoletto, os outros actantes não possuem paixões complexas com relação aos seus objetos.

O Duque de Mântua é investido de duas paixões simples decorrentes de um /quererser/ e um /querer-não-ser/ em relação ao objeto 'mulher', ou seja, o desejo e o desprendimento, respectivamente. Na ária mais famosa desta ópera, "La donna è mobile"121,

\footnotetext{
${ }^{119}$ SEGRETO, V. R. La genesi di Rigoletto - Un viaggio nell'epistolario verdiano. In: Teatro Regio di Parma. Website da instituição. Disponível em: <http://www.teatroregioparma.org>). Acesso em: ago 2008. 120 "Quanto affetto!... quali cure! / Che temete, padre mio?" Ato I - Cena X.

121 "La donna è mobile qual piuma al vento, muta d'accento e di pensiero.

Sempre un amabile leggiadro viso, in pianto o in riso, è menzognero.
} 
vemos que todos os valores disfóricos que caracterizam a mulher como ser "volúvel", falso (de "rosto amável e gracioso" que "no choro ou no riso" é "mentiroso"), traiçoeiro ("é sempre miserável quem confia nela") contrastam com valores eufóricos de beleza e sensualidade. $\mathrm{Na}$ última estrofe ("Todavia não sente / totalmente feliz / quem sobre aquele seio não brinda ao amor"), a conjunção adversativa "todavia" introduz a ideia da necessidade do objeto como complemento do ser, não obstante todos os seus valores disfóricos.

Aliás, "La donna è mobile" encabeça uma verdadeira isotopia temática na figura do sujeito que se sente atraído e ao mesmo tempo repelido pelo objeto. Em "Questa o quella per me pari sono", ${ }^{122}$ o duque está seguro de não se deixar seduzir por nenhuma mulher ("do meu coração o império não cedo"), já que, para ele, "a constância" é um valor disfórico (é "tirana do coração"). Podemos ir mais longe e afirmar que, em relação ao amor, o duque está em conjunção apenas com o semema do amor carnal (“não há amor se não há liberdade”) e está em total disjunção com o semema do amor espiritual ("só quem quer conserve-se fiel”). Para ele, o amor deve ser intenso e passageiro, porque "se hoje esta me agrada, amanhã talvez seja outra".

Entretanto, para conquistar seus objetos, o duque adota o discurso contrário, porque sabe que, para algumas mulheres, a constância é um valor eufórico. Com Gilda, ele não apenas muda o seu discurso, como muda também seu nome e sua condição social. Vira o estudante pobre Gualtier Maldé e lhe jura "afeto imutável".

Quando Gilda é raptada e a cisão ocorre, o duque canta, sozinho, "Ella mi fu rapita", ${ }^{123}$ em que se depreende uma possível transformação do sujeito pelo objeto.

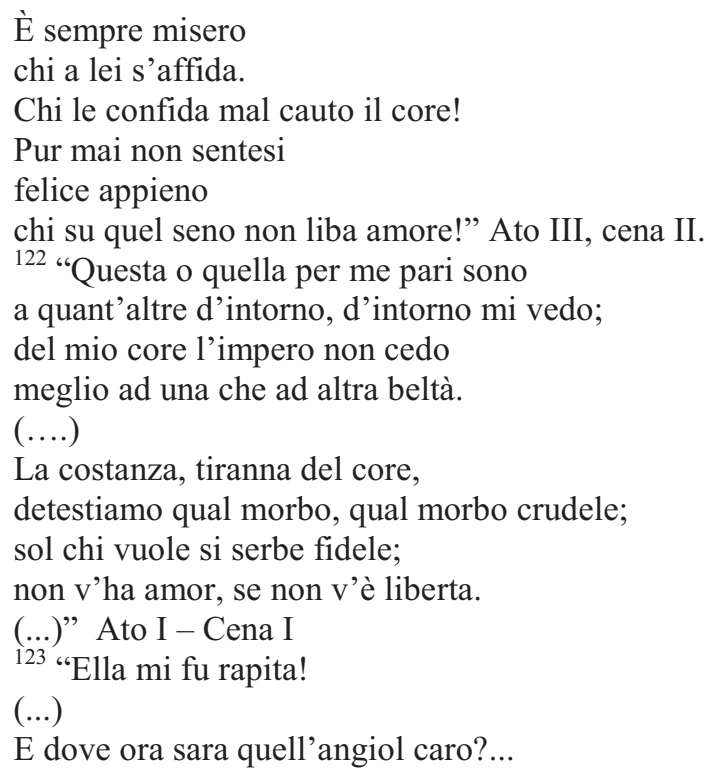


Confidencia para si que Gilda foi a primeira que pôde acender em seu coração "a chama de constantes afetos". De fato, ele reconhece no objeto seu valor de pureza, e diante de uma mulher "tão pura" acreditou-se "quase levado à virtude".

A ideia de dois sujeitos diversamente modalizados (o duque, como vimos, modaliza-se em /querer-não-ser/, enquanto Gualtier Maldé /quer-ser/), também é reforçada, todo o tempo, pela melodia, que assume ritmo mais acelerado quando há o desejo junto ao desprendimento e, ao contrário, ritmo desacelerado quando o desejo é acompanhado de um profundo apego.

Portanto, assim que o duque sabe que Gilda se encontra sob o seu teto, a melodia acelera subitamente e ele se deixa levar prontamente por seu "possante amor". Decide não esperar mais pelo objeto e deixa cair, de uma vez por todas, sua máscara (“Ah, saiba finalmente quem a ama / conheça finalmente quem sou / aprenda que também em trono / há escravos do Amor"). ${ }^{124}$

Narratologicamente, a trama se desenvolve a partir dos relacionamentos do duque com os objetos dos outros sujeitos, gerando-lhes programas narrativos de liquidação da falta. Seu papel actancial é o de destinador (antagonista), visto que será o responsável pelas cisões entre os sujeitos Monterone, conde e Rigoletto e seus respectivos objetos filha, esposa e Gilda.

Entretanto, é importante dizer que Rigoletto protagoniza a história por não ser apenas mais um sujeito de falta, mas, ao contrário, por desenvolver um percurso que foi de codestinador (co-antagonista) a sujeito oprimido. Se, em uma primeira parte, ele se identificava com o duque, por ajudar nas cisões e ridicularizar os sujeitos de falta, na segunda parte passa a se identificar com Monterone, que teve a filha seduzida e abandonada pelo antagonista, o Duque.

Aliás, a associação entre os actantes Monterone e Rigoletto vai além da condição de pai desonrado e se constitui também pela voz: ambos são barítonos! Curiosamente, Ponelle faz algo que seria impossível no palco e sincretiza os dois sujeitos na figura do ator. De fato, Rigoletto e Monterone são representados impecavelmente no filme pelo mesmo ator, Ingvar Wixell.

colei che prima potè in questo core destar la fiamma di costanti affetti?... colei si pura, al cui modesto sguardo quasi spinto a virtù talor mi credo!... (...)" A to II - Cena I.

124 "Ah! Sappia alfin chi l'ama, / conosca alfin chi sono, / apprenda ch'anco in trono / ha degli schiavi Amor") Ato II - Cena II. 
Monterone, por sua vez, modaliza-se pelo /querer-fazer/ mal ao actante responsável por sua falta e, por isso, vai até o palácio ducal "reclamar a sua honra", afetado pela revolta ("Sim, Monterone... a minha voz / tal como um trovão vos abalará onde quer que seja"). ${ }^{125}$ Rigoletto, porém, não crê na instalação de um /poder-fazer/ e ridiculariza-o perante todos (“O senhor conjurou contra nós, / e nós, sinceramente clementes, perdoamos..."). ${ }^{126}$

Tomado pela cólera, Monterone adquire competência para /poder-fazer/ mal ao duque e a seu cúmplice por meio de atos ilocutórios de ameaça ("Virei gritar até que veja continuar inulto / de minha família o atroz insulto") ${ }^{127}$ e maldição ("Jogar o cão ao leão moribundo / é vil, oh Duque... e você, serpente, / (para Rigoletto) / você que ri da dor de um pai, / seja amaldiçoado!" $" 128$.

A maldição, por sua vez, constitui um tema fulcral desta ópera, a ponto de quase darlhe o título. Para Verdi, "todo sujeito está naquela maldição, que se torna também moral". ${ }^{29}$ A curta aparição de Monterone e sua fala limitada a poucas palavras proféticas foram estratégias utilizadas pelo autor para que o efeito da maldição recaísse sobre Rigoletto de modo fatal, como o próprio compositor assinalou. ${ }^{130}$

A pertinácia da maldição ainda é reforçada pelo concertato ${ }^{131}$ dos cortesãos ("É vã qualquer palavra, afasta-te daqui / vai, treme, oh covarde, da ira soberana / você a provocou, não há mais esperança / esta foi uma hora fatal para você’).

A partir da maldição, o estado juntivo de Rigoletto com Gilda atinge o grau máximo de tensividade-fórica: temos um sujeito do ser esperando a cisão ("Aquele velho me amaldiçoava!... tal pensamento / por que conturba a cada minuto a minha mente?”). ${ }^{132}$ Quando finalmente ela ocorre, o sujeito de Rigoletto modaliza-se por um /querer-fazer/ mal ao duque, acompanhado de um /poder-fazer/ e um /saber-fazer/ ("Sim, vingança, tremenda

\footnotetext{
125 "Sì, Monteron... la voce mia / qual tuono vi scuoterà dovunque". Ato I - Cena VI.

126 "Voi congiuraste contro noi, signore; / e noi, e noi, clementi in vero, perdonammo..." Idem.

127 "Verró a gridare fino a che vegga restarsi inulto / di mia famiglia l'atroce insulto;" Idem.

128 "Slanciare il cane a leon morente / è vile, o Duca... e tu, serpente, / (a Rigoletto) / tu che d'un padre ridi al dolore, / sii maledetto!" Idem.

${ }^{129}$ SEGRETO, V. R. La genesi di Rigoletto - Un viaggio nell'epistolario verdiano. In Teatro Regio di Parma. Website da instituição. Disponível em: <http://www.teatroregioparma.org. Acesso em: ago 2008.

130 "Un infelice padre che piange l'onore tolto alla sua figlia, deriso da un buffone di corte che il padre maledice, e questa maledizione coglie in una maniera spaventosa il buffone, mi sembra morale e grande al sommo grande. Bada che La Vallier non deve comparire (come nel francese) che due volte e dire pochissime parole profetiche. Ti ripeto che tutto il soggetto stà in quella maledizione". Idem.

${ }^{131} \mathrm{O}$ concertato designa as cenas de conjunto de que participam vários solistas.

132 “Quel Vecchio maledivami!... tal pensiero / Perché conturba ognor la mente mia!...” Ato I - Cena VIII.
} 
vingança / desta alma é só desejo (...) Como um raio lançado por Deus, / atingir-te o bufão saberá"). ${ }^{133}$

O cumprimento da maldição pode ser entendido, em última instância, como a sanção do destinador-julgador sobre a performance do sujeito, considerando não apenas o seu PN (programa narrativo) de liquidação da falta, como também seu PN anterior de co-destinador em relação aos primeiros sujeitos de falta, ou seja, Monterone e o conde. Podemos dizer que Rigoletto colheu o que plantou, que provou do seu próprio veneno, que fez por merecer, etc.

Além disso, temos a sanção do destinador-julgador em relação ao Duque, que pode ser interpretada positivamente (se considerarmos que ele viverá feliz e impune) ou negativamente (se considerarmos que, com a morte de Gilda, o Duque perdeu sua única possibilidade de redenção).

Paralelamente à sanção pré-definida pela maldição, é importante analisar outros programas narrativos que contribuíram para que o PN de vingança de Rigoletto se voltasse contra ele mesmo.

Em primeiro lugar, há que se considerar a função do Conde de Ceprano dentro da narrativa. Apesar de ele demonstrar um /querer-fazer/ mal ao antagonista - que está disputando com ele seu objeto - seguindo-o na festa, é contra o bufão que ele se modaliza de um /poder-fazer/ e um /saber-fazer/ mal, incitando os outros cortesãos a vingar-se ("Vingança do bobo! / Quem não tem um rancor contra ele? (...) Vingança! Esta noite quem tem coração esteja na minha casa armado"). ${ }^{134}$ Assim, o Conde arquiteta todo o plano para raptar Gilda e, com a ajuda dos outros cortesãos, realiza-o.

Temos também os actantes Sparafucile e Maddalena, que deveriam ser apenas instrumentos de vingança, mas se modalizam e geram outro PN. O objeto de valor de Sparafucile é o dinheiro, obtido com o auxílio do seu punhal e em sua irmã Maddalena, uma prostituta que atrai suas vítimas ("Me ajuda minha irmã... / Pelas ruas dança, .... é bela... / Quem quero ela atrai.... e aí...”). ${ }^{135}$

\footnotetext{
133 “Sì, vendetta, tremenda vendetta / di quest'anima è solo desio (....) Come fulmin scagliato da Dio, / te colpire il buffone saprà." Ato II - Cena VIII.

134 "Vendetta del pazzo! / Contr'esso un rancore di noi chi non ha? (...) Vendetta! Sta notte chi ha core sia in armi da me." Ato I - Cena V.

135 "M'aiuta mia sorella... / Per le vie danza,.. è bella... / Chi voglio attira... e allor..." Ato I - Cena VII.
} 
Entretanto, Maddalena se deixa seduzir pelo Duque e estabelece com ele um estado de conjunção ("Parece um Apolo aquele jovem... eu o amo... / e ele me ama..."). ${ }^{136}$ Por isso, ela se modaliza de um /querer-fazer/ bem ao seu objeto ("Temos que salvá-lo") ${ }^{137}$, acompanhado de um /poder-fazer/ e um /saber-fazer/ (“(...) fácil te revelo um plano”), ${ }^{138}$ até que, finalmente, persuade seu irmão ("Se antes que a noite tenha chegado / alguém entrar aqui, por ele morrerá" $)^{139}$ e o faz matar outra pessoa em seu lugar.

Finalmente, temos o estado passional de Gilda em relação ao duque ("Eu o amo"). ${ }^{140}$ Mesmo em disjunção com ele ("Iníquo traidor!") ${ }^{141}$, o amor persiste ("Infeliz coração traído, / por angústia não exploda, / Por que oh crédulo coração, / um tal homem devia amar!"), ${ }^{142}$ a ponto de ela se modalizar por um /querer-fazer/ bem ao duque acompanhado de um /poderfazer/ e um /saber-fazer/ (“Oh que tentação!... morrer pelo ingrato!...”). ${ }^{143}$

A última cena da ópera mostra um percurso sensorial do sujeito em estado de completa euforia por crer no sucesso de seu PN de vingança e as sucessivas transformações passionais que sofre diante da possibilidade de falha no programa até sua efetiva constatação de derrota.

Ao receber o saco, o sujeito de Rigoletto entra em conjunção com o suposto corpo morto do Duque; ele quer vê-lo (“queria-o ver!...") $)^{144}$. Além de ter finalmente liquidado a falta, seu ser passa subitamente de dominado a dominante (“Agora veja-me, oh mundo!... / Este é um bufão, e um potente é este! / Ele está sob os meus pés!... está morto! oh alegria!...”), ${ }^{145} \mathrm{e}$, portanto, a conjunção é plena.

Mas, quando Rigoletto ouve a voz do duque, seu estado se transforma violentamente, passando da conjunção ao estado confuso, de atordoamento ("Que voz!... ilusão noturna é esta!...). ${ }^{146}$ Então ele sente a matéria no saco ("Eu tremo... é corpo humano!....") ${ }^{147}$ e vê com horror que se trata do corpo moribundo da filha. O atordoamento aumenta (“Ah, não!... é

\footnotetext{
136 “Somiglia un Apollo quel giovine... io l'amo... / ei m'ama...(...)" Ato III - Cena VI.

137 "Salvarlo dobbiamo" Idem.

138 “(...) facil ti svelo un progetto” Idem.

139 "Se pria ch'abbia il mezzo la notte toccato / Alcuno qui giuga, per esso morra”. Idem.

140 "Io l'amo" Ato III - Cena I.

141 "Iniquo traditor". Ato III - Cena III

142 "Perché o credulo mio core, / um tal uomo dovevi amar!” Ato III - Cena III

143 “Oh qual tentazione!... morir per l'ingrato!...” Ato III - Cena VI

144 "Egli è là!... morto!... oh si!... vorrei vederlo!” Ato III - Cena IX

145 “Ora mi guarda, o mondo!... / Quest'è un buffone, ed un potente è questo! / Ei sta sotto i miei piedi!... è desso! Oh gioja...!" Ato III - Cena IX

146 "Qual voce!.. Illusion notturna è questa!.." Idem.

147 "Io tremo... è umano corpo!" Idem.
} 
impossível!...). ${ }^{148}$ Aos poucos, a dimensão cognitiva invade a cena, Gilda esclarece o que aconteceu (“Eu te enganei... culpada fui... / amei-o demais... agora morro por ele!...”), ${ }^{149}$ Rigoletto interpreta a sanção ("Deus tremendo! Ela própria foi atingida pela flecha da minha justa vingança!”), ${ }^{150}$ Gilda pede-lhe que perdoe a ela e ao duque (“Ah, que eu me cale!... a mim... a ele perdoe!..." $)^{151}$, diz que olhará por ele junto de sua mãe ("Lá no céu, perto da mãe... / eternamente por você.... pregarei”) ${ }^{152}$ e, finalmente, morre. Seu estado plenamente disfórico agora irrompe no grito desesperado: “Ah, a maldição!". ${ }^{153}$

Como podemos observar, a ópera constitui uma fonte didática muito fecunda para a aplicação da análise semiótica, não apenas nos níveis narrativo e discursivo, mas, sobretudo, no nível fundamental, para o qual contribui também a linguagem musical e a cênica.

Com esse tipo de análise, conseguimos explicar a organização imanente do texto operístico, ou a sua gramática interna. A ideia é fazer com que os alunos descubram esse sistema de regras para que possam se beneficiar dos efeitos de sentido produzidos, inclusive daqueles decorrentes do pathos da música e dos atores.

Além disso, esta metodologia pretende conciliar à abordagem interna o exame da inserção contextual do texto. Significa que, por meio das isotopias temáticas e figurativas, abordaremos a intertextualidade na tentativa de descobrir em que medida os valores aflorados na ópera regulavam a sociedade em determinada época. ${ }^{154}$

Além disso, os documentos que remontam à enunciação, como as cartas trocadas entre Verdi, Piave e Marzari na época da composição de Rigoletto ou, ainda, a biografia do autor se houver pertinência crítica - podem atestar a coerência do texto.

A propósito de Rigoletto, o musicólogo Richard Mohr associou o número de vezes que o confronto entre pais e filhos aparece nas obras verdianas à obsessão que Verdi parece ter com a perda, muito cedo, de Verginia e Icilio, os dois filhos que teve com Margherita Barezzi (COELHO, 2002). A mesma associação pode ser lida no comovente artigo Conflito entre pais e filhos nas óperas de Verdi, de Sergio Casoy (2006).

\footnotetext{
148 “Ah, no!... è impossibil!..”" Ato III - Cena Utima

149 "V'ho l'ingannato... colpevole fui... / l'amai troppo... ora muojo per lui!..." Idem.

150 "(Dio tremendo! Ella stessa fu côlta / dallo stral di mia giusta vendetta!)” Idem.

151 “Ah, ch'io taccia!.. a me... a lui perdonate!...” Idem.

152 "lassù... in cielo, vicina alla madre... / in eterno per voi... pregherò" Idem.

153 "Ah! la maledizione!!" Idem.

${ }^{154}$ Cf. o tema da "mulher volúvel" arrolado no tópico que trata da escolha da ópera Rigoletto.
} 
Portanto, tocará ao didatizador do material autêntico julgar relevantes o contexto social-histórico de produção e recepção do texto e a biografia do autor para a leitura do objeto, o que pode ser decidido a partir de uma análise mais minuciosa sobre as marcas da enunciação.

\subsection{OBJETIVOS}

Os objetivos do curso "Rigoletto: per gli amanti della lingua e della cultura italiana" são:

- Objetivo geral cognitivo: conhecer a ópera Rigoletto no original;

- Objetivos gerais de habilidade: compreender e interpretar a ópera Rigoletto;

- Objetivos gerais de atitude: posicionar-se criticamente diante da ópera Rigoletto.

- Objetivos específicos cognitivos:

- conhecer e estudar cada composição da ópera Rigoletto;

- ampliar o repertório linguístico e cultural;

- interagir com outras formas de expressão;

- contextualizar árias conhecidas, como "La donna è mobile", "Caro nome", "Bella figlia dell'amore", entre outras;

- visitar os temas mais importantes de Rigoletto;

- conhecer um pouco da terminologia operística.

- Objetivos específicos de habilidade:

- identificar os elementos eufóricos e disfóricos na música, nos gestos e nas vozes das personagens;

- utilizar outras linguagens como contexto para compreender a língua cantada e escrita;

- atualizar a língua do século XIX;

- proceder às inversões poéticas dos versos de Rigoletto; 
- inferir os versos por meio do contexto;

- desambiguar os versos por meio do contexto;

- parafrasear a linguagem poética de Rigoletto;

- saber utilizar o discurso indireto;

- descrever as personagens de Rigoletto;

- saber contar a trama de Rigoletto;

- explicar as ações das personagens, bem como suas motivações;

- reconhecer o tema da "mulher volúvel" como lugar comum na literatura;

- distinguir e debater vários temas de Rigoletto.

- Objetivos específicos de atitude:

- debater os temas de Rigoletto assumindo uma posição crítica;

- exprimir o gosto pela ópera Rigoletto;

- reconhecer a importância de Rigoletto para a cultura italiana.

\subsection{O PÚBLICO}

Para poder frequentar o curso "Rigoletto: per gli amanti della lingua e della cultura italiana", o aluno deverá possuir, minimamente, o nível B1 de língua italiana, de acordo com a classificação do Quadro Europeu Comum de Referência para as Línguas.

Dentro de uma escala global, o aluno B1 encontra-se em um nível intermediário e pode ser também definido um utilizador independente da língua estrangeira. Segundo o descritor do Quadro, esse aluno "é capaz de compreender as questões principais, quando é usada uma linguagem clara e padronizada e os assuntos the são familiares (temas abordados no trabalho, na escola e nos momentos de lazer, etc.). É capaz de lidar com a maioria das situações encontradas na região onde se fala a língua-alvo. É capaz de produzir um discurso simples e coerente sobre assuntos que lhe são familiares ou de interesse pessoal. Pode 
descrever experiências e eventos, sonhos, esperanças e ambições, bem como expor brevemente razões e justificações para uma opinião ou um projeto." ${ }^{155}$

Para justificar a definição do público, é preciso ressalvar que a linguagem da ópera não se contrapõe ao tipo de linguagem definida "clara" e "padronizada", já que além de contar uma história linear e em discurso direto, utiliza outras formas de expressão para "esclarecer" sua linguagem verbal poética e historicamente datada. Além disso, a metodologia adotada no curso - considerando a forma em que a ópera é apresentada e como os alunos procedem à realização das atividades - tem a função de auxiliar ao máximo o aluno nesse sentido.

Da mesma forma, os assuntos tratados em Rigoletto não deverão representar um entrave na compreensão da obra, considerando que a maioria dos temas abordados no drama pertencem à esfera de temas universais e de interesse geral.

Quanto à produção, esta se limitará à descrição das cenas, das impressões pessoais e à redação das respostas às questões sobre a ópera, sempre em dupla ou em grupos, o que garantirá o trabalho cooperativo, a não exposição do aluno e, consequentemente, o não levantamento do seu filtro afetivo.

Portanto, considera-se que o aluno B1 possui, enquanto utilizador independente do idioma, maturidade suficiente para "sobreviver" às dificuldades linguísticas intrínsecas à linguagem da ópera, bem como para perfazer com eficácia todos os objetivos propostos, como poderemos verificar mais adiante, no item que trata da avaliação e dos resultados.

\footnotetext{
${ }^{155}$ Tav. 1. Livelli comuni di riferimento: scala globale. Livello Intermedio, B1: "È in grado di comprendere i punti essenziali di messaggi chiari in lingua standard su argomenti familiari che affronta normalmente al lavoro, a scuola, nel tempo libero ecc. Se la cava in molte situazioni che si possono presentare viaggiando in una regione dove si parla la lingua in questione. Sa produrre testi semplici e coerenti su argomenti che gli siano familiari o siano di suo interesse. È in grado di descrivere esperienze e avvenimenti, sogni, speranze, ambizioni, di esporre brevemente ragioni e dare spiegazioni su opinioni e progetti. p.32
} 


\subsection{A ORGANIZAÇÃO DO CORPUS}

Para introduzir os alunos no drama de Rigoletto, o curso abordará o tema da "mulher volúvel" na primeira aula, com uma unidade de aprendizagem motivacional de $3 \mathrm{~h}$ exclusivamente reservada para o estudo da ária "La donna è mobile".

A ideia é que a didatização dessa unidade reproduza a didatização de toda a ópera, seja em relação aos objetivos, seja em relação às técnicas e também ao percurso didático sugerido. Em outras palavras, a intenção é que essa primeira unidade de aprendizagem funcione como um protótipo do curso, de modo que o aluno já possa criar as estratégias cognitivas para estudar a ópera.

Enquanto unidade motivacional, o estudo da ária deverá instigar os alunos a conhecerem melhor o seu personagem e as condições de enunciação, o que implica em levar a querer conhecer a ópera Rigoletto. Além disso, permanecerá como motivação de fundo durante todo o percurso, já que problematiza diversas questões na ópera, como o papel da mulher, o amor carnal versus o amor espiritual, a necessidade do objeto de desejo ou a volubilidade feminina em contraposição à constância masculina. Esta ária pode ser vista, enfim, como o leitmotiv da ópera ${ }^{156}$ e, portanto, deverá conduzir os alunos na construção do seu sentido.

De fato, torna-se muito produtivo, do ponto de vista didático, apresentar a ária primeiro no seu formato popular, para que o aluno se sinta apenas "revisitando um clássico", sem o compromisso de entender o que está realmente por trás dos enunciados propostos. Posteriormente, a releitura da ária no seu contexto dramatúrgico - no terceiro ato - elucidará, finalmente, o seu sentido imanente, trazendo a satisfação da descoberta e do "dever cumprido".

As próximas unidades de aprendizagem estão divididas em atos, estando o primeiro subdividido em duas unidades, ou seja, antes e depois da Maldição. Seguem-se os outros dois, e, por fim, trabalha-se o contexto social-histórico da ópera.

\footnotetext{
156 "La donna è mobile” é cantada três vezes de forma diversa na ópera.
} 
A organização programática de Rigoletto está assim definida:

\begin{tabular}{|c|c|c|}
\hline $\begin{array}{l}\text { UNIDADES DE } \\
\text { APRENDIZAGEM }\end{array}$ & CONTEÚDO PRINCIPAL & DURAÇÃOO \\
\hline "La donna è mobile" & Motivação: tema principal da ópera & $2 \mathrm{~h}$ \\
\hline $\begin{array}{l}\text { Ato I - primeira } \\
\text { parte: cenas I - VI }\end{array}$ & $\begin{array}{l}\text { Performance }{ }^{157} \text { do Duque e Rigoletto na Corte } \\
\text { de Mântua e PN de revolta de Monterone }\end{array}$ & $3 \mathrm{~h}$ \\
\hline $\begin{array}{l}\text { Ato I - segunda } \\
\text { parte: cenas VII - } \\
\text { XIV }\end{array}$ & $\begin{array}{l}\text { Performance de Rigoletto fora da Corte e PN } \\
\text { de vingança dos cortesãos }\end{array}$ & $3 \mathrm{~h}$ \\
\hline Ato II & $\begin{array}{l}\text { Performance do Duque sem seu objeto de } \\
\text { valor, PN de desejo do Duque e PN de revolta } \\
\text { de Rigoletto }\end{array}$ & $3 \mathrm{~h}$ \\
\hline Ato III & PN de vingança de Rigoletto e sanção & $3 \mathrm{~h}$ \\
\hline $\begin{array}{l}\text { Contexto social- } \\
\text { histórico }\end{array}$ & O epistolário verdiano e a Trilogia Romântica & $2 \mathrm{~h}$ \\
\hline
\end{tabular}

Tabela 2. Unidade Didática "Rigoletto: per gli Amanti della Lingua e della Cultura Italiana"

\subsection{AS ATIVIDADES PROPOSTAS}

A primeira unidade de aprendizagem é composta de 15 atividades, divididas em atividades de motivação, de compreensão escrita, de interpretação e análise e de abordagem humanístico-afetiva, como podemos verificar a seguir a partir da descrição de cada uma:

1) Depois da habitual apresentação dos alunos e do professor, este escreve na lousa a palavra "donna" (“mulher”), para que os alunos façam todas as associações possíveis na tentativa de descrevê-la. Essa técnica, conhecida como brainstorming, é muito útil para introduzir os alunos no tema de forma lúdica.

\footnotetext{
${ }^{157}$ Neste caso, o termo performance designa o componente do percurso narrativo do sujeito e, portanto, é entendido como aquisição e/ou produção de valores descritos, opondo-se à competência considerada uma sequência programada de aquisições modais (GREIMAS; COURTÉS, 2008).
} 
Provate a riflettere sulla parola "donna". Che cosa vi fa venire in mente?

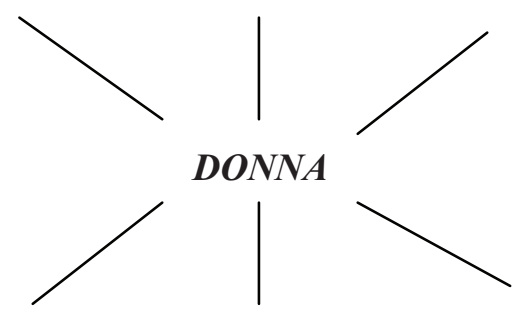

Figura 1. Atividade número 1 da unidade de aprendizagem "La donna è mobile"

2) O segundo passo é fazê-los ouvir a ária "La donna è mobile" e escrever as três primeiras coisas que lhes vêm à mente, tanto com relação à melodia, quanto com relação ao texto. Antes de proceder à verificação, o professor pedirá que confrontem com seus colegas o que escreveram. Durante a verificação - que não supõe a correção do conteúdo em "certo" ou "errado", dada a subjetividade que envolve a tarefa - o professor pode comparar o resultado às associações feitas na atividade anterior, a fim de se confrontar sumariamente os valores femininos expostos no brainstorming aos valores expressos na ária.

Dopo aver sentito l'aria, scrivete le prime tre cose che vi vengono in mente riguardo la melodia e il testo. Confrontatevi poi con dei compagni!

Figura 2. Atividade número 2 da unidade de aprendizagem "La donna è mobile"

3) Com o propósito de fazer-compreender a letra de "La donna è mobile", o aluno deverá completar o cloze parafrátisco facilitado da ária ${ }^{158}$. O professor pode aproveitar o momento da correção para esclarecer outras eventuais dúvidas de léxico, morfossintaxe ou sintaxe.

\footnotetext{
${ }^{158}$ Na paráfrase, o adjetivo "mobile" não foi modificado porque isso constituirá uma tarefa do aluno, como é possível verificar nas próximas atividades.
} 
Seguite il testo originale e completate gli spazi della parafrasi con le parole riportate nel riquadro.

\begin{tabular}{|c|c|c|}
\hline & \multicolumn{2}{|c|}{$\begin{array}{l}\text { imprudentemente opinione si fida completamente brinda } \\
\text { bugiardo }\end{array}$} \\
\hline 1 & La donna è móbile & La donna è mobile \\
\hline 2 & qual piuma al vento & come una piuma al vento \\
\hline 3 & muta d'accento & cambia discorso \\
\hline 4 & e di pensiero & \\
\hline 5 & Sempre un amabile & Ha sempre un volto \\
\hline 6 & leggiadro viso & amabile e leggiadro \\
\hline 7 & in pianto o in riso & che però̀ è \\
\hline 8 & è menzognero & in pianto o in riso \\
\hline 9 & É sempre misero & É sempre misero \\
\hline 10 & chi a lei s'affida & _di una donna \\
\hline 11 & chi le confida & chi le affida \\
\hline 12 & mau cauto il core! & _ il cuore! \\
\hline 13 & Pur mai non sentesi & Tuttavia non si sente mai \\
\hline 14 & felice appieno & felice \\
\hline 15 & chi su quel seno & chi su quel seno \\
\hline 16 & non liba amore! & non__all'amore! \\
\hline
\end{tabular}

Figura 3. Atividade número 3 da unidade de aprendizagem "La donna è mobile"

As próximas questões procuram despertar o aluno para a análise semiótica do texto no que concerne aos valores atribuídos à categoria "mulher" e "homem", pela teoria do quadrado semiótico das diferenças ${ }^{159}$ (questão 4), à significação contextual do adjetivo "mobile"

\footnotetext{
${ }^{159}$ No quadrado semiótico de A. J. Greimas, um termo não se define substancialmente, mas sim pelas relações que contrai. A categoria "mulher", por exemplo, pode ser assim definida:$$
\text { mulher homem }
$$$$
X
$$$$
\text { กลี้-homeก กีลัก-mulher }
$$

A partir do termo "mulher", chegamos ao seu termo contraditório "não-mulher" (dada a impossibilidade de os dois termos coexistirem). Este último assevera, por implicação, a existência do termo "homem" (visto que o que não é "mulher" é "homem"). O "homem", por sua vez, também possui um termo a ele contraditório, o "nãohomem", implicando no termo "mulher" (o que não é "homem" é "mulher"). Assim, podemos estabelecer uma relação de complementaridade entre "não-mulher" e "homem", e também entre "não-homem" e "mulher", já que a negação de um deles implica, implícita ou explicitamente, a afirmação do outro (GREIMAS; COURTÉS, 2008).
} 
(questões 5 e 6), ao ponto de vista do personagem sobre o valor da mulher e seus efeitos sobre o homem (questões 7 e 8), ao tempo da ária (questão 9), à intertextualidade (questão 10), e às características do personagem (questão 15).

4) Nesta atividade, os alunos deverão extrair da ária o maior número possível de atributos femininos e masculinos, separá-los em atributos positivos e negativos, e ajustá-los em uma tabela. Durante a correção, o professor deverá acrescentar os contrários, caso os alunos não o tenham feito.

Nell'aria quali qualità vengono attribuite alla donna? E all'uomo? Trovatene il maggior numero e riempite la tabella.

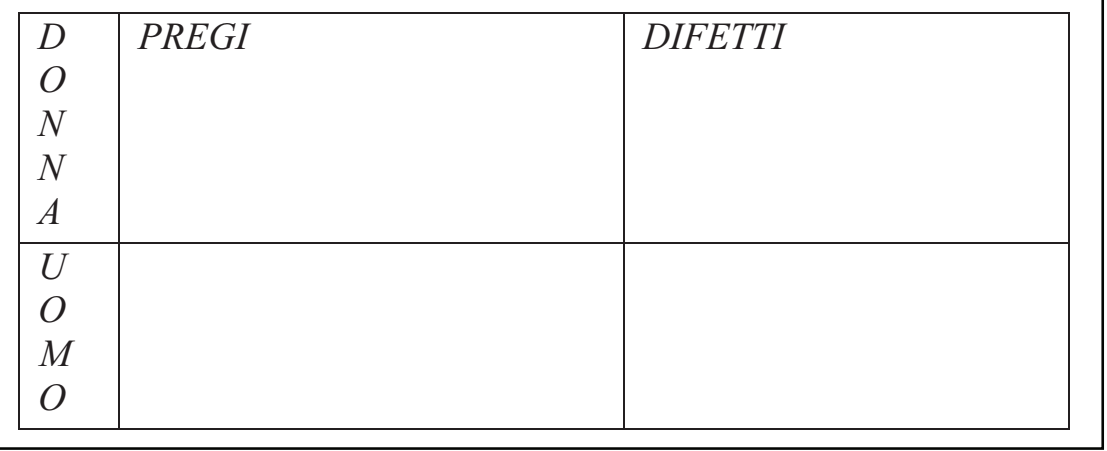

Figura 4. Atividade número 4 da unidade de aprendizagem "La donna è mobile"

5) Mas o que se entende por "mobile" ("móvel”) como qualificação do ser? Esta atividade prevê que o aluno encontre, a partir do contexto, sinônimos para esse lexema.

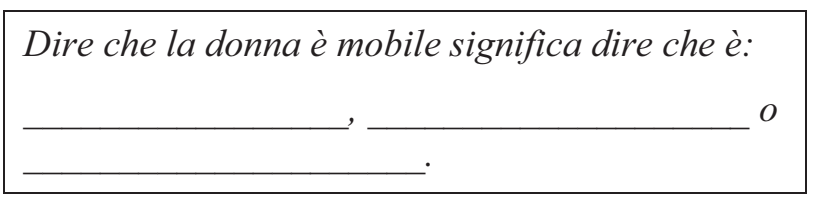

Figura 5. Atividade número 5 da unidade de aprendizagem "La donna è mobile"

Este esquema servirá de base para pressupor os valores masculinos a partir dos valores femininos evidenciados no texto. Se a mulher é "móvel", o homem é "imóvel". Se a mulher é "mentirosa", o homem é "verdadeiro", etc., justificando, assim, o princípio estrutural enunciado por F. de Saussure, segundo o qual "na língua não há senão diferenças". 
6) E por que a mulher é móvel? Em sequência, o aluno terá que inferir qual é a performance da mulher segundo o personagem Duque de Mântua.

Secondo il personaggio dell'aria, perché la donna si fa mobile?

Figura 6. Atividade número 6 da unidade de aprendizagem "La donna è mobile"

7) O homem, por sua vez, é visto como uma vítima da manipulação feminina. A próxima atividade pede que o aluno explique a posição do homem diante da performance feminina.

In che senso l' uomo è una vittima delle donne? Cosa può fare lui per non soffrire?

Figura 7. Atividade número 7 da unidade de aprendizagem "La donna è mobile"

8) Continuando as reflexões sobre a posição masculina diante da manipulação feminina, os alunos deverão explicar a necessidade do homem em ceder aos encantos femininos pelo entendimento da necessidade de junção entre ambos, em que a mulher é vista como elemento complementar ao homem, sem a qual ele não se sentiria pleno, finalizando, assim, a composição do quadrado semiótico.

L'ultima strofa sembra contrapporsi alle altre. Siete d'accordo? Motivate la vostra risposta e trovate nel testo gli elementi che ti aiutano a confermarla.

Figura 8. Atividade número 8 da unidade de aprendizagem "La donna è mobile"

9) Finalmente, o aluno será levado a refletir sobre o tempo desta ária universal, ou melhor, sobre a infinitização dos valores remissivos e emissivos da ária, que condenam ambos os sujeitos à manipulação e à vitimização eterna. Ele terá que identificar no texto tudo que ajude a ilustrar a eternização da performance de ambos os sujeitos, ou seja, os verbos no presente, o advérbio "sempre" - que aparece duas vezes na ária - a expressão "in pianto o in riso" ("no choro ou no riso") e o advérbio "mai". 
La condizione della donna manipolatrice e dell'uomo manipolato può cambiare? Trovate nel testo le parole o espressioni che giustifichino la vostra risposta.

Figura 9. Atividade número 9 da unidade de aprendizagem "La donna è mobile"

10) Mas será que as ideias veiculadas por "La donna è mobile" são novas ou já foram apresentadas em outros textos? Nesta atividade, que servirá de motivação para a próxima, os alunos deverão apostar em alguns nomes que tenham compartilhado da mesma visão feminina e poderão, inclusive, sugerir outros.

$$
\begin{aligned}
& \text { Scegliete fra questi nomi alcuni che, secondo voi, possano aver condiviso } \\
& \text { la visione della "donna mobile". } \\
& \text { ( ) Virgilio ( ) Petrarca ( ) Boccaccio ( ) Bocage ( ) Camones ( ) } \\
& \text { Victor Hugo ( ) altri: }
\end{aligned}
$$

Figura 10. Atividade número 10 da unidade de aprendizagem "La donna è mobile"

11) O professor distribuirá 14 fragmentos poéticos ${ }^{160}$ a cada aluno para que leia e copie ao menos uma palavra que indique a semelhança com a temática da nossa ária. Feito isso, ele deverá circular pela classe e trocar sua poesia com outro aluno. Ao final da atividade, o professor projetará no retroprojetor cada um dos 14 fragmentos, com os nomes dos seus respectivos autores, e os alunos deverão detectar as semelhanças com base nas suas anotações ${ }^{161}$.

Leggete le 14 poesie in circolazione per la classe e scrivete almeno una parola per ogni frammento che indichi la similitudine con il tema de "La donna è mobile”.

Figura 11. Atividade número 11 da unidade de aprendizagem "La donna è mobile"

\footnotetext{
${ }^{160}$ Os fragmentos foram reunidos por Alberto de Faria, sob o título de Volubilidade Feminina, e encontram-se no website da Academia Brasileira de Letras. Disponível em:

$<$ http://www.academia.org.br/abl/cgi/cgilua.exe/sys/start.htm?infoid=59\&sid=205> $>$. Acesso em: jun 2009.

${ }^{161}$ Se houver mais de 14 alunos na classe, o professor poderá distribuir alguns fragmentos repetidos. Se, ao contrário, sobrarem fragmentos, estes não serão distribuídos, o que não impede a sua projeção durante a verificação. As poesias encontram-se no anexo B.
} 
As últimas atividades desta unidade de aprendizagem procuram estabelecer uma interação maior com o aluno por meio da abordagem humanístico-afetiva, em que se aproveita o tema para que o aluno possa falar ou escrever sobre suas experiências pessoais, além de expressar sua opinião sobre o assunto tratado.

12) Nesta questão, o aluno é chamado diretamente para posicionar-se diante do tema.

E voi, siete d'accordo con la visione dell'aria e delle poesie che avete letto? Perché?

Figura 12. Atividade número 12 da unidade de aprendizagem "La donna è mobile"

13) Esta é uma atividade lúdica que consiste em dividir a classe em, pelo menos, dois grupos de alunos com opiniões contrárias ao tema da ária. Em conjunto, cada grupo deverá criar duas frases comparativas - uma relacionada à mulher e a outra ao homem - seguindo o modelo dos primeiros versos do texto: "La donna è mobile qual piuma al vento".

Dividetevi in due squadre: una che condivide e l'altra che non condivide la stessa opinione del soggetto dell'enunciazione dell'aria e, seguendo il modello dei primi versi del testo ("La donna è mobile qual piuma al vento"), proponete un paragone per l'uomo e un'altro per la donna.

Figura 13. Atividade número 13 da unidade de aprendizagem "La donna è mobile"

14) Ainda servindo-se da criatividade, os alunos deverão se reunir em grupos e se colocar na pele do Duque da ária para escolher o tipo mais característico da "mulher móvel". Deverão ainda motivar a sua escolha. 


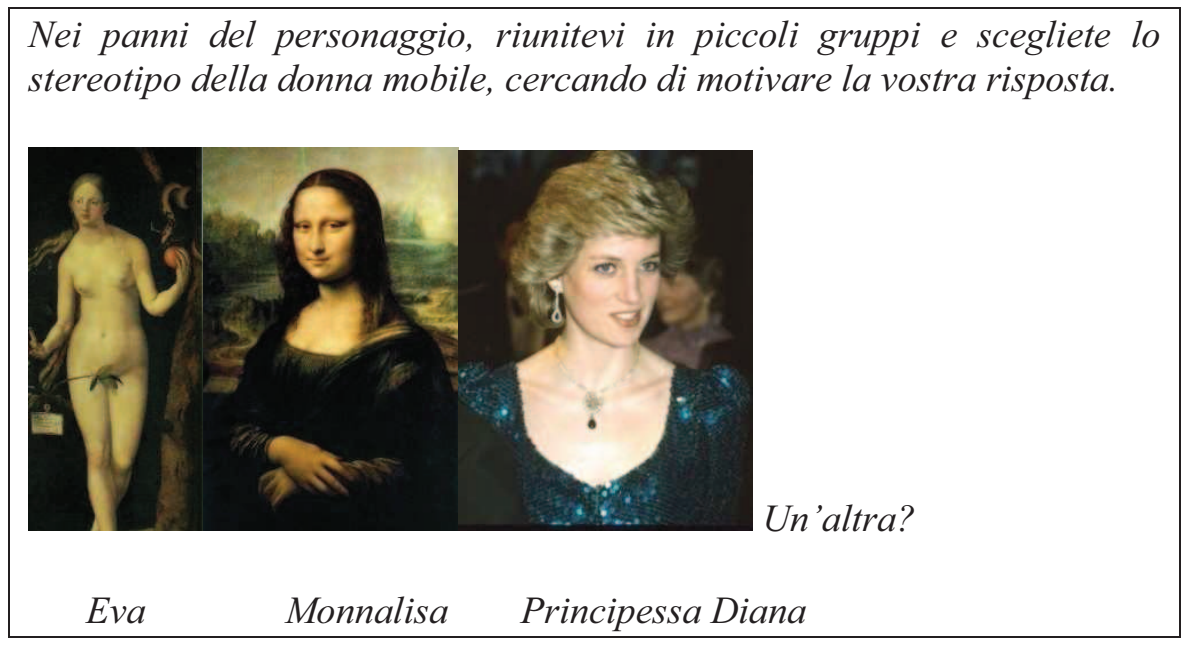

Figura 14. Atividade número 14 da unidade de aprendizagem "La donna è mobile"

15) Finalmente, os alunos terão que imaginar as características físicas e morais que compõem o persongem, sujeito da enunciação de "La donna è mobile", sempre motivando as suas escolhas. A verificação está reservada para depois da visão da primeira cena do Ato I, ou seja, depois da atividade de abertura da ópera.

Adesso immaginate la composizione fisica e morale del personaggio dell'aria "La donna è mobile" e descrivetelo, cercando di motivare, come al solito, le vostre scelte!

Figura 15. Atividade número 15 da unidade de aprendizagem "La donna è mobile"

A partir da segunda unidade de aprendizagem, a ópera será estudada na sua sequência cênica desde o prelúdio até a última cena do último ato.

\section{Prelúdio.}

1) Os alunos apenas ouvirão a música de abertura de Rigoletto e imaginarão uma cena qualquer para aquela composição. A partir da técnica de transcodificação sonora, trabalhamos a capacidade inventiva dos alunos, além de provocar a manifestação das emoções causadas pela música.

Sentite adesso il preludio di Rigoletto e immaginate una scena che corrisponda alla sua musica. Confrontatevi poi con dei compagni! 
Figura 16. Primeira atividade da unidade de aprendizagem "Ato Iprimeira parte"

2) A segunda atividade inclui uma nova audição da abertura, desta vez com a visão da cena que compõe a versão de Ponnelle. De fato, o diretor ilustra a antecipação da tragédia de Rigoletto com o personagem transtornado indo ao encontro do corpo morto de sua filha e tomando-o em seus braços. Além de os alunos verificarem se o que haviam sentido se aproxima ao que, de fato, a cena mostra, esta atividade é muito interessante porque também utiliza a técnica de transcodificação. Desta vez, porém, é por meio da técnica de transcodificação visual que os alunos descreverão a cena.

Dopo aver visto la scena che illustra il preludio dell'opera provate a descriverla!

Figura 17. Segunda atividade da unidade de aprendizagem "Ato Iprimeira parte"

Ato I. Cena I. A primeira cena retrata uma festa no palácio ducal, em que o Duque de Mântua conta ao cortesão Borsa sobre a sua nova aventura, uma jovem que conheceu na igreja, além de se mostrar vivamente interessado em cortejar a Condessa de Ceprano, presente na festa com seu marido. Logo após a conversa com o cortesão, o Duque entoa a ária "Questa o quella per me pari sono", revelando assim o seu caráter libertino.

1) A primeira atividade pede que os alunos descrevam a cena com base nos elementos melódicos, gestuais e, eventualmente, textuais que terão conseguido captar da cena.

Descrivete la scena in base alla melodia, ai gesti e alle eventuali parole che siete riusciti a capire.

Figura 18. Terceira atividade da unidade de aprendizagem "Ato I primeira parte"

2) A segunda atividade já inclui o uso do libreto e consiste em julgar as afirmações verdadeiras ou falsas. 
Da questo primo dialogo tra il Duca di Mantova ed il cortigiano Borsa si può capire che:

a. ( ) Il Duca si è innamorato di una borghese in un remoto calle.

b. ( ) Il Duca la vede durante tutte le feste della chiesa da tre mesi.

c. ( ) La borghese abita vicino alla chiesa.

d. ( ) Lei conosce l'identità del Duca.

e. ( ) Il Duca entra misteriosamente in casa sua ad ogni festa.

f. ( ) La sposa di Ceprano è la più bella della corte.

g. ( ) La sua condizione di moglie impedisce però al Duca di farle la corte.

Figura 19. Quarta atividade da unidade de aprendizagem “Ato I - primeira parte”

3) A próxima atividade prevê que os alunos descrevam o caráter do personagem Duque de Mântua, buscando na ária "Questa o quella per me pari sono" os elementos que possam ajudar na sua caracterização.

Come possiamo descrivere il Duca di Mantova? Cercate nell'aria "Questa o quella per me pari sono" gli elementi necessari per farlo.

Figura 20. Quinta atividade da unidade de aprendizagem "Ato I - primeira parte"

Extra: Antes de partir para a segunda cena, faz-se pertinente retomar a primeira unidade de aprendizagem por meio da técnica de interdiscursividade e pedir aos alunos que estabeleçam relações isotópicas entre a melodia e o texto de ambas as árias.

Che similitudini possiamo stabilire tra la melodia e il testo di "La donna è mobile" e "Questa o quella per me pari sono"?

Figura 21. Sexta atividade da unidade de aprendizagem "Ato I - primeira parte"

Cena II. Esta cena traz o affair entre o Duque e a Condessa de Ceprano.

1) A atividade prevê que os alunos descrevam o assédio do Duque e o comportamento da Condessa diante dele, visando a perceber os afetos de ambos os personagens. Como sempre, à descrição dos gestos (a Condessa se afasta e vira o rosto, tentando escapar às investidas do Duque, embora demonstre prazer) e da melodia (andamento acelerado do 
Duque com interrupções de andamento lento da Condessa), os alunos certamente acrescentarão vários elementos textuais, tanto na segunda visão com legenda como na leitura do libreto, o que lhes permitirá reforçar e comprovar a definição do estado de distensão do Duque em relação ao estado de retenção da Condessa.

Ecco le abitudini goderecce del Duca, questa volta cercando di sedurre la Contessa di Ceprano. Descrivete lo stato di animo dei due personaggi, trovando nella scena tutti gli elementi possibili per giustificare le vostre parole.

Figura 22. Sétima atividade da unidade de aprendizagem "Ato I - primeira parte"

Cena III. Enquanto o Duque tenta seduzir a Condessa, Rigoletto ridiculariza o Conde de Ceprano, que vê toda a cena sem poder fazer nada para impedir os assédios do rival.

1) Pela primeira vez, os alunos enfrentarão um exercício de compreensão oral durante a segunda visão da cena, o que dispensa o uso da legenda. A correção será feita pelo professor e, portanto, é necessário pedir aos alunos que durante esta atividade não abram o libreto. 


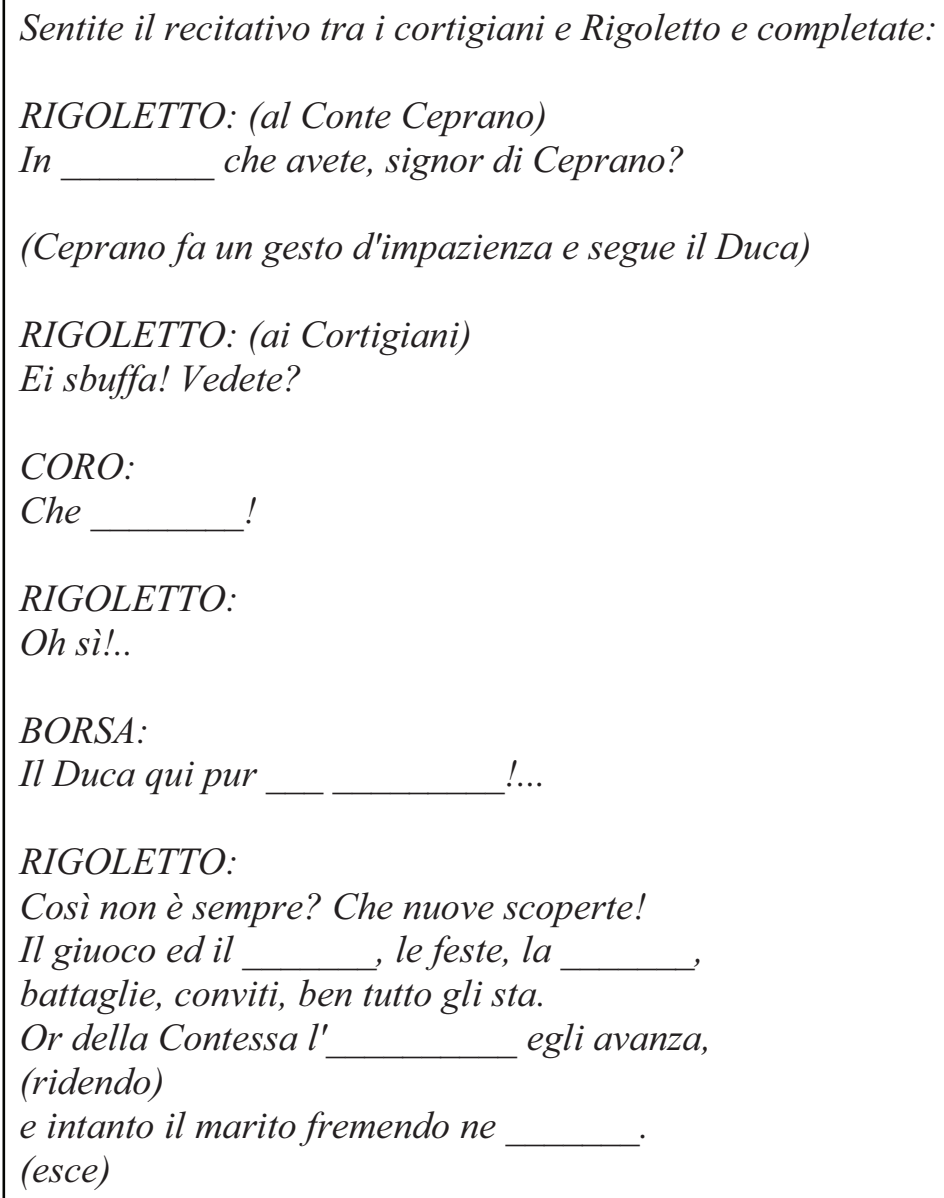

Figura 23. Oitava atividade da unidade de aprendizagem "Ato Iprimeira parte"

Cena IV. Marullo entra em cena, reúne os cortesãos e lhes conta que Rigoletto possui uma amante.

1) Com o propósito de continuar o trabalho com a compreensão oral, os alunos responderão a uma questão referencial bem abrangente.

\section{Cosa racconta Marullo agli altri cortigiani?}

Figura 24. Nona atividade da unidade de aprendizagem "Ato Iprimeira parte"

Cena V. Na presença de Ceprano, Rigoletto insinua maneiras pelas quais o Duque poderia afastar o Conde e, assim, seduzir sua esposa. Quando Rigoletto chega a ponto de sugerir que o Conde fosse executado, Ceprano embravece num impulso de desafiá- 
lo para um duelo. Os outros cortesãos demonstram repúdio e desprezo por Rigoletto. O Duque, nesse momento, mostra-se irritado.

1) Os alunos deverão dizer quais são as três maneiras, mas, desta vez, terão que inferir o seu significado na cena, já que seus conselhos são feitos valendo-se de meias palavras e gestos.

Il Duca vuole sedurre la contessa di Ceprano ma non sa cosa fare di suo marito. Quali sono i tre consigli che gli dà il buffone?

$\left.1^{\circ}\right)$

$\left.2^{\circ}\right)$

$\left.3^{\circ}\right)$

Figura 25. Décima atividade da unidade de aprendizagem "Ato Iprimeira parte"

2) Em seguida, realizarão uma atividade de correspondência entre as diversas falas de um concertato e seus personagens. É interessante pedir aos alunos que tentem fazê-la sem o auxílio do libreto, o que provavelmente implicará em uma nova visão da cena. 
Abbinate adesso i versi di questo concertato ai seguenti personaggi:

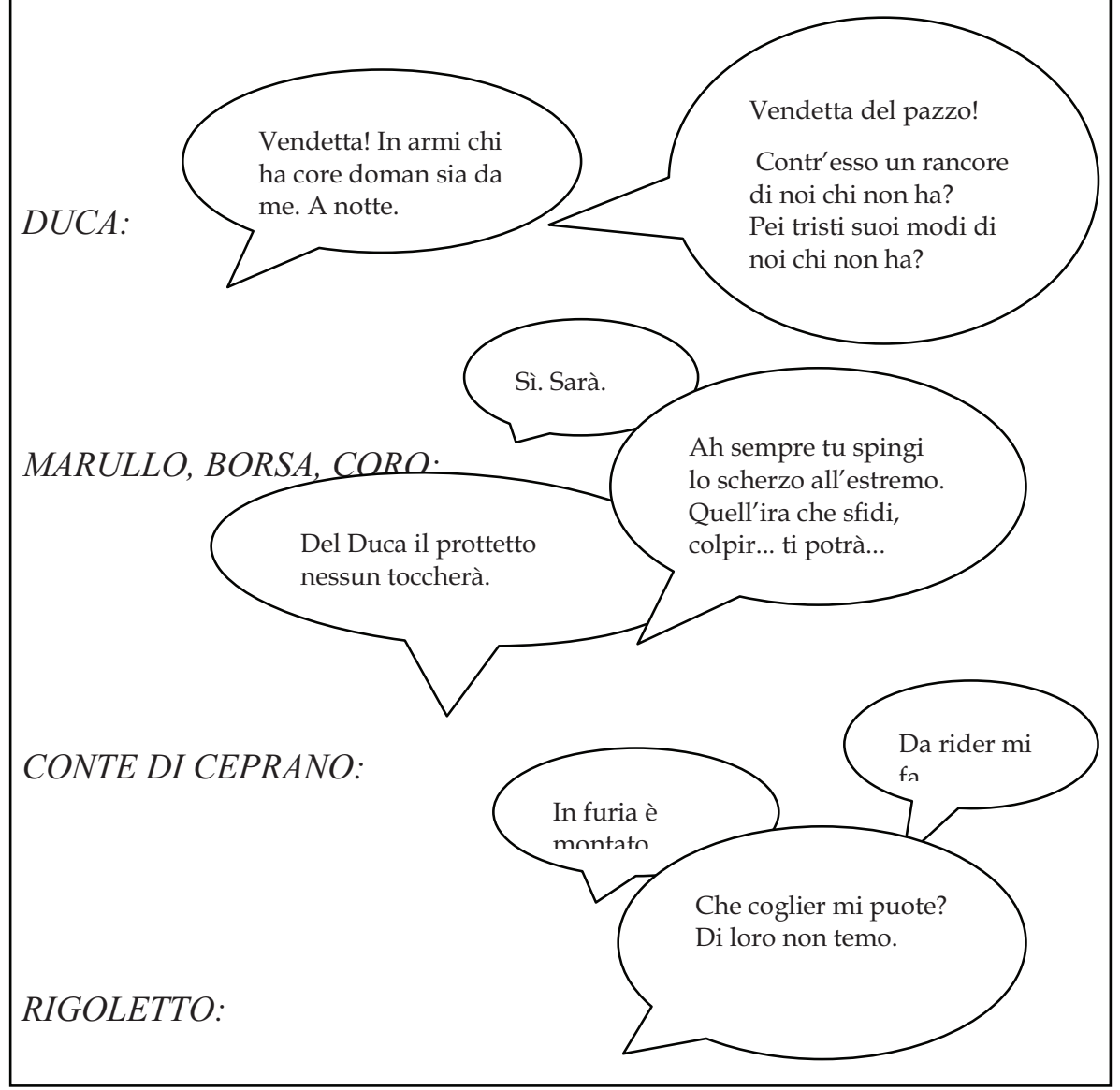

Figura 26. Décima primeira atividade da unidade de aprendizagem "Ato I - primeira parte"

3) Está ainda prevista a resposta a três perguntas abertas inferenciais sobre o conteúdo da atividade de número 2 e sobre a mudança imprevista ao final da melodia desta cena, referente à entrada do personagem Monterone.

\section{Rispondete:}

a) Perché i cortigiani si ribellano contro il buffone?

b) Perché Rigoletto dimostra di non essere preoccupato?

c) Alla fine di questa scena la melodia cambia improvvisamente. Perché?

Figura 27. Décima segunda atividade da unidade de aprendizagem "Ato I - primeira parte" 
Cena VI. Monterone entra na corte acusando o Duque de ter desonrado sua filha. Após ser zombado por Rigoletto, Monterone lança uma maldição contra o Duque e o bufão.

1) Podemos dizer que a questão de letra "c" da atividade anterior serve de motivação para a resposta a esta nova pergunta aberta que se refere à entrada de Monterone. Os alunos farão hipóteses sobre o que teria levado Monterone a interromper a festa, ajudados principalmente pela representação cênica das personagens e pela captação de algumas palavras.

Chi entra nella corte? Cosa sarà venuto a fare?

Figura 28. Décima terceira atividade da unidade de aprendizagem "Ato I - primeira parte"

1) Depois dessa pergunta abrangente, os alunos deverão praticar mais uma vez a habilidade de compreensão escrita a partir das paráfrases dos versos de Monterone. Para tanto, deverão encontrar os versos que tragam o sentido equivalente à descrição dos seus enunciados.
Trovate $i$ versi in cui:
a) Monterone dice che è impossibile non sentirlo:
b) Monterone li chiamerà anche dopo la morte:
c) Monterone maledice il buffone ed il Duca:
d) I cortigiani dicono che Rigoletto merita la maledizione:
e) I cortigiani dicono che non c'è speranza per Rigoletto:

Figura 29. Décima quarta atividade da unidade de aprendizagem "Ato I - primeira parte"

Fim de ato: Ao final de cada ato (ou parte dele), teremos uma atividade de reordenação dos parágrafos de toda a unidade de aprendizagem parafraseada em forma de prosa. Os alunos deverão recordar todo o percurso para conseguir realizar esta tarefa, que deverá ser feita em casa, eventualmente com o uso do libreto. 
Riordinate i pezzi della trama di questa prima parte dell'Atto I:

(1) A Mantova, nel XVI secolo.

( ) Improvvisamente irrompe in scena il Conte di Monterone (baritono), venuto a chiedere ragione al Duca, che ha sedotto la sua giovane figlia. Rigoletto si prende ferocemente gioco di lui, deridendolo, facendogli il verso, e fingendosi il Duca per rispondere alle sue accuse. Il Duca fa arrestare Monterone, e questi scaglia allora una solenne maledizione contro di lui e contro Rigoletto, che ha osato ridere del dolore di un padre.

( ) Gli espone quindi, in una vivace ballata, la sua concezione dell'amore: per lui tutte le donne sono uguali, e non intende concedere a nessuna il suo cuore per più di un giorno ("Questa o quella per me pari sono»). Riprendono le danze, ed a tempo di Minuetto il Duca si mette a corteggiare la Contessa di Ceprano (mezzosoprano), la più bella della festa.

( ) Una festa in un salone del palazzo ducale. Il Duca di Mantova (tenore) confida al cortigiano Matteo Borsa (tenore) che intende arrivare presto alla conclusione dell'avventura con la bella e sconosciuta fanciulla che da tre mesi egli incontra tutte le domeniche in chiesa.

( ) Il buffone rientra quindi in scena, suggerendo al Duca di liberarsi del geloso Conte di Ceprano, per poterne meglio insidiare la moglie: potrebbe farlo incarcerare, esiliarlo, o addirittura fargli tagliare la testa. La pesante ironia di Rigoletto suscita ovviamente le ire del Conte, e fa nascere un desiderio di vendetta in tutti i cortigiani, da tempo infastiditi dai modi del buffone.

( ) Tutti i presenti, dapprima quasi sussurrando e poi sempre più forte, uniscono le loro voci per invitare Monterone ad andarsene, ed a temere le gravi conseguenze dell'ira del Duca; il Conte continua intanto a ripetere la sua maledizione, e Rigoletto incomincia a meditare spaventato sul suo orribile gesto ("Oh tu che la festa audace hai turbato»).

( ) Mentre i cortigiani cantano in coro il loro odio per Rigoletto, questi si dice sicuro di essere intoccabile come protetto del Duca, ed il Duca lo rimprovera bonariamente. La tensione si risolve ben presto, comunque, ed il gaio spirito della festa prende di nuovo il sopravvento.

( ) Fa una breve comparsa in scena Rigoletto (baritono), il gobbo buffone di corte, commentando le abitudini goderecce del suo signore. Si balla quindi un Perigordino, una vivace danza francese, ed il cortigiano Marullo (baritono) informa i presenti, con loro grande stupore, che Rigoletto possiede un'amante.

Figura 30. Décima quinta e última atividade da unidade de aprendizagem "Ato I - primeira parte" 
Cena VII. Rigoletto sai do palácio ducal e recorda a maldição de Monterone com uma estranha sensação, talvez um mau pressentimento. Aproxima-se Sparafucile, oferecendo seus serviços como assassino profissional.

1) Após a primeira visão da cena, os alunos deverão fazer suposições sobre quem seja este novo personagem. Deverão ainda extrair da cena elementos para justificar suas hipóteses.

Chi potrebbe essere questo nuovo personaggio? A partire dalla melodia, dai gesti e dalle parole che siete riusciti a capire cercate di formulare qualche ipotesi su di lui.

Figura 31. Primeira atividade da unidade de aprendizagem "Ato I segunda parte"

2) A técnica utilizada para esta atividade é a de atualização de diálogo aberto. A partir da fala de um dos dois personagens, os alunos deverão formular a fala do outro e, assim, completar todo o diálogo parafraseado.

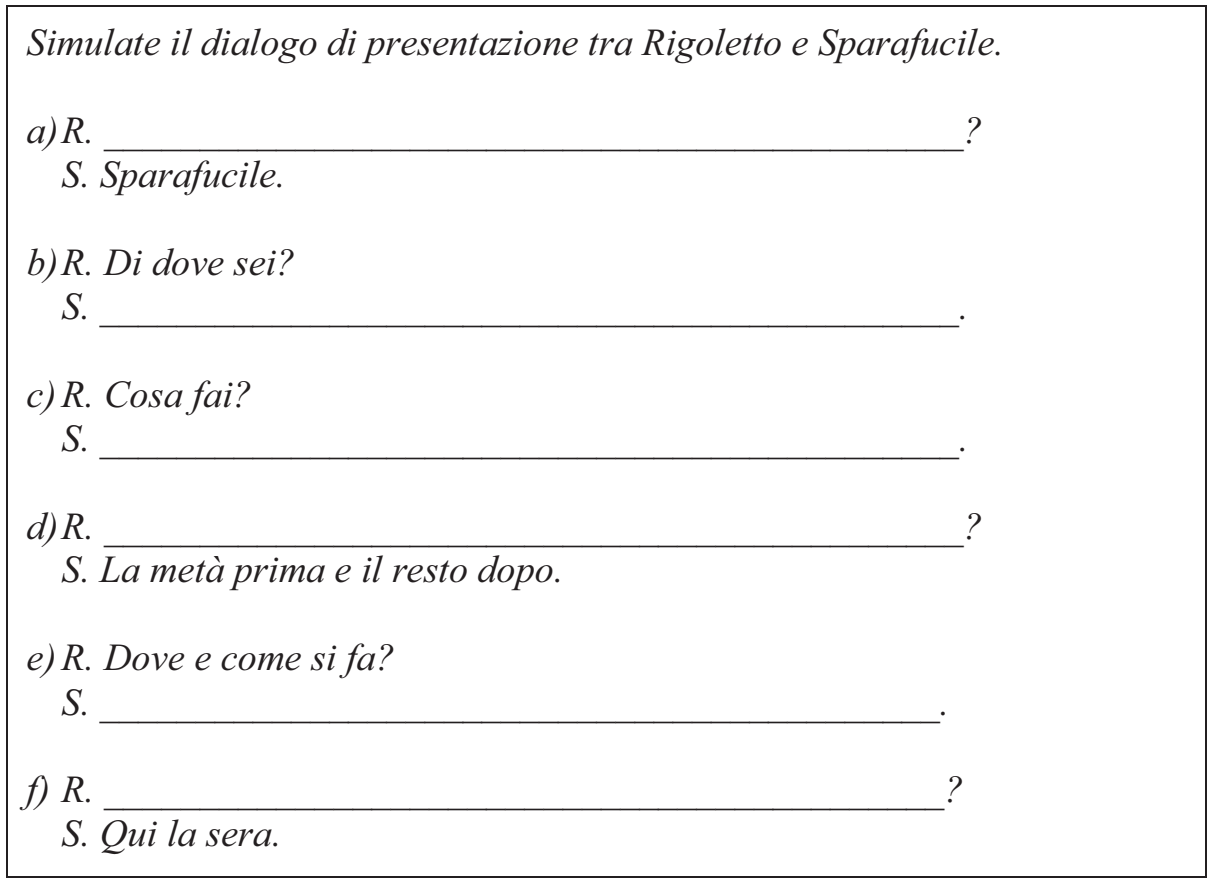

Figura 32. Segunda atividade da unidade de aprendizagem "Ato Isegunda parte" 
Cena VIII. Só, Rigoletto recorda sua vida, as humilhações pelas quais já passou por ser aleijado e bobo da corte. Pensa, então, em sua filha, Gilda, única pessoa no mundo capaz de solicitar sua face terna e humana.

1) Este parece ser o momento ideal para pedir aos alunos que reflitam sobre a condição do personagem Rigoletto e seu estado de animo. Assim, após a primeira visão da ária "Cortigiani, vil razza dannata", os alunos deverão descrever o estado de ânimo do personagem Rigoletto, buscando na cena os elementos possíveis para fazê-lo.

Descrivete lo stato di animo del personaggio Rigoletto, cercando nella scena tutti gli elementi possibili per giustificare le vostre parole.

Figura 33. Terceira atividade da unidade de aprendizagem "Ato Isegunda parte"

2) Esta atividade utiliza a técnica do cloze parafrástico para trabalhar a compreensão escrita dos alunos. Eles deverão completar a paráfrase da ária de Rigoletto com palavras que deem sentido e coerência ao texto e que correspondam aos versos do libreto.

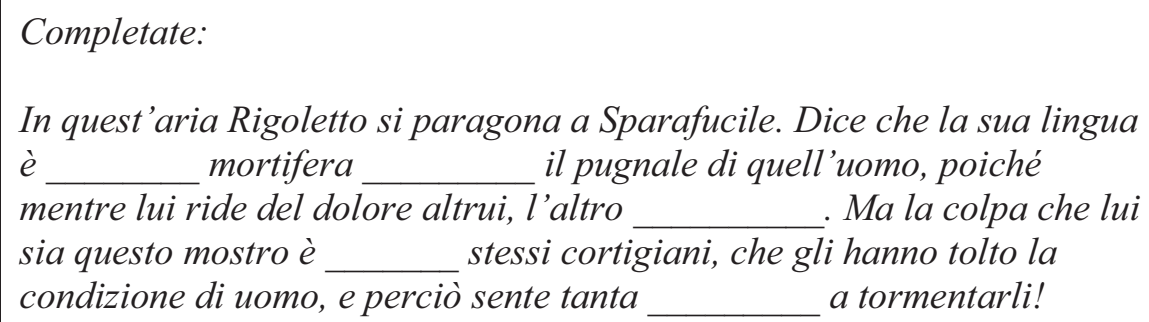

Figura 34. Quarta atividade da unidade de aprendizagem "Ato Isegunda parte"

3) Antes de passar à próxima cena, é interesante pedir aos alunos que expliquem o verso "Ma in altr'uom qui mi cangio" ("Mas em outro homem aqui me transformo"), para que eles possam discorrer sobre os dois sujeitos distintos que concorrem no personagem Rigoletto. Certamente, o advérbio "qui” do verso refere-se ao lugar onde o personagem se encontra naquele momento, o qual deverá ser inferido pela imagem de Gilda que o espera de braços abertos para dentro de um portão. Além disso, o seu contrário, o "lá" implícito, deverá ser mencionado na explicação do verso. 
Spiegate il verso "Ma in altr'uom qui mi cangio".

Figura 35. Quinta atividade da unidade de aprendizagem "Ato I segunda parte"

Cena IX. Em casa, Rigoletto e Gilda conversam sobre os cuidados que ela deve ter em não aparecer diante de nenhum homem. Gilda lhe pergunta sobre sua vida oculta, e ele se recusa a dizer quem é, mas lhe fala sobre sua mãe.

1) Os alunos responderão a um questionário sobre o conteúdo desta cena. As três primeiras perguntas são de tipo inferencial e geral, enquanto as quatro últimas são de tipo referencial e específico.

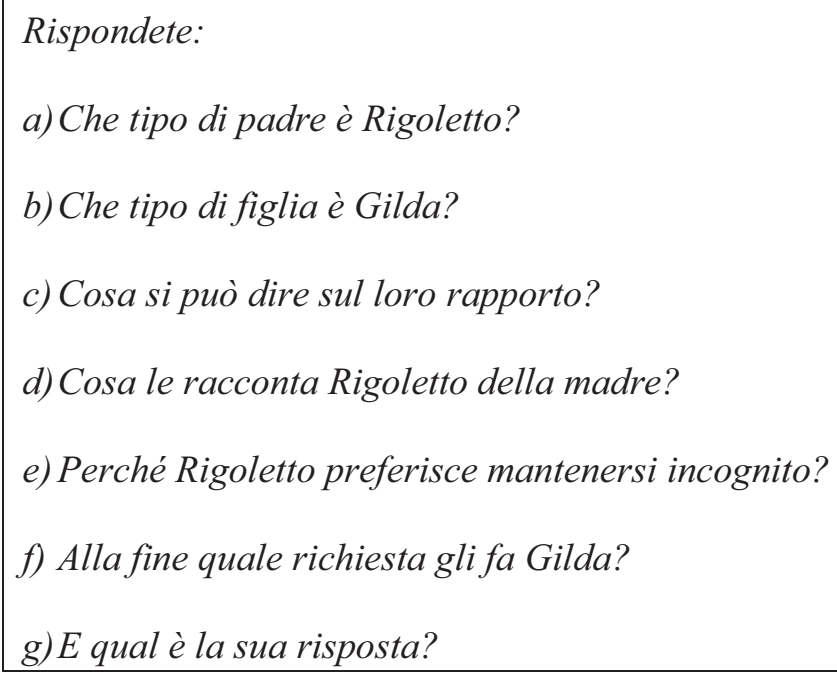

Figura 36. Sexta atividade da unidade de aprendizagem "Ato I segunda parte"

Cena X. Ao notar o desejo da filha de sair de casa, Rigoletto entoa a ária "Veglia, o donna, questo fiore" para pedir à governanta Giovanna que a proteja e a vigie.

1) Em primeiro lugar, os alunos descreverão o estado de ânimo de todos os personagens envolvidos na cena, inclusive do Duque, que aparece no final. Provavelmente, mencionarão a extensão da cena, que, além de ser percebida pelos próprios alunos 
enquanto telespectadores, é percebida também pela governanta e pelo Duque, que fazem gestos de impaciência esperando o fim da ária para que o bufão vá embora. 
Descrivete lo stato di animo di tutti i personaggi che compaiono in questa scena, tenendo conto della melodia, del canto, dei gesti e di altri aspetti della scena.

Figura 37. Sétima atividade da unidade de aprendizagem "Ato Isegunda parte"

2) Agora, os alunos deverão explicar o motivo de tal extensão, relacionando-o diretamente ao estado de ânimo de Rigoletto, ou seja, o seu temor. Durante a verificação, o professor pode atentar para a questão de que quanto maior o medo de perda do objeto, maior o desejo de estar com ele, de preservá-lo consigo e não deixá-lo sozinho.

Il compositore Verdi conferisce al duetto "Ah, veglia, o donna, questo fiore" il carattere da lui stesso definito scena eterna. Quale sarebbe, secondo voi, il motivo di tale estensione?

Figura 38. Oitava atividade da unidade de aprendizagem "Ato Isegunda parte"

Finalmente, estão previstas duas atividades para o estudo dos versos de "Veglia, o donna, questo fiore":

3) A primeira é encontrar na ária todos os elementos que qualifiquem a figura da flor, assim como aqueles que se opõem a ela.

Trovate nell'aria "Veglia o donna questo fiore" tutti gli elementi che qualificano la parola "fiore" e quelli che si oppongono a essa.

Figura 39. Nona atividade da unidade de aprendizagem "Ato I segunda parte"

4) Em seguida, deverão completar o cloze parafrástico.

Completate:

Rigoletto prega la custode Giovanna di vegliare Gilda, un fiore che stato affidato , e non lasciar che si offuschi il suo candor. La prega inoltre di difenderlo furore dei che piegato altri e di restituirglielo immacolato. 
Figura 40. Décima atividade da unidade de aprendizagem "Ato I segunda parte"

Cena XI. Antes de sair, Rigoletto se assusta com um barulho e faz novas recomendações a Giovanna.

1)A atividade prevé que os alunos descreveram o caráter da governanta, que se cala sobre a presença do Duque ao ser subornada por ele. Para tanto, deverão, como sempre, escolher da cena os elementos passíveis de compor as características desse personagem.

Come possiamo definire il carattere della custode Giovanna? Cercate nella scena gli elementi che vi possano aiutare nella sua descrizione.

Figura 41. Décima primeira atividade da unidade de aprendizagem "Ato I - segunda parte"

Cena XII. Rigoletto sai e Gilda fala com Giovanna sobre seu amor secreto até ser interrompida pelo Duque.

As atividades para esta cena são:

1)Uma pergunta aberta sobre o que deixou Gilda com remorso.

\section{Perché Gilda ha dei rimorsi?}

Figura 42. Décima segunda atividade da unidade de aprendizagem "Ato I - segunda parte"

2) Uma pergunta aberta sobre a mudança súbita de melodia e a definição das emoções do Duque naquele momento.

Che cambiamento della melodia si verifica quando entra in scena il

Duca? Come possiamo definire le sue emozioni in questo momento?

Figura 43. Décima terceira atividade da unidade de aprendizagem "Ato I - segunda parte"

3) Uma pergunta aberta sobre a identidade que o Duque inventou para Gilda e os motivos que ele teve para fazê-lo, antecipando, dessa forma, a próxima atividade. 
Che identità ha inventato il Duca a Gilda? Perché?

Figura 44. Décima quarta atividade da unidade de aprendizagem "Ato I - segunda parte"

4) Finalmente, está prevista também para esta cena a discussão dos versos "Signor ne principe - io lo vorrei; Sento che povero - più lo amerei” (“Senhor nem príncipe - eu o queria; Sinto que pobre - mais o amaria"). Os alunos serão chamados a discutir sobre que tipo de mulher os diria, reevocando, ainda que implicitamente, o tema da "mulher volúvel”.

Che tipo di donna direbbe i versi "Signor ne principe - io lo vorrei; Sento che povero - più lo amerei"?

Figura 45. Décima quinta atividade da unidade de aprendizagem "Ato I - segunda parte"

Cena XIII. Gilda fica sozinha e entoa a ária "Caro nome", lembrando de seu amado.

1) A atividade pede que os alunos atualizem o léxico de "Caro nome", cujas palavras arcaicas ou de uso literário estarão evidenciadas no texto. Para facilitar a realização da atividade (a primeira com esta técnica até aqui), os alunos deverão utilizar as palavras do quadro.

Gualtier Maldè!... nome di lui sì amato,

Scolpisciti nel core innamorato!

desiderio cosi

Caro nome che il mio cor

Festi primo palpitar,

Le delizie dell'amor

Mi dêi sempre rammentar!

Col pensiero il mio desir

A te ognora volerà,

E pur l'ultimo sospir,

Caro nome, tuo sarà.

devi hai fatto

menzionare

anche

sempre

imprimiti

Figura 46. Décima sexta atividade da unidade de aprendizagem "Ato Isegunda parte"

Cena XIV. Os cortesãos avistam Gilda. 
1) Dada a pequena extensão desta cena e a facilidade linguística da maioria de seus versos, proponho uma atividade de compreensão oral de versos inteiros. Para facilitar a compreensão, porém, o professor pode colocar a legenda em, pelo menos, duas audições, visto que o trecho é cantado por um coro.

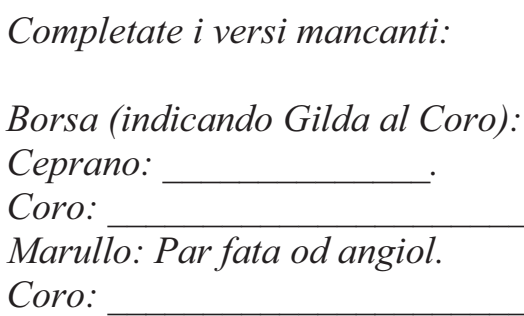

Figura 47. Décima sétima atividade da unidade de aprendizagem "Ato I - segunda parte"

Cena XV. Os cortesãos sequestram Gilda com a ajuda do próprio Rigoletto.

1) Os alunos deverão explicar a façanha dos cortesãos. A técnica empregada é a de descrição.

Ecco la scena del rapimento di Gilda. In che modo i cortigiani hanno ingannato Rigoletto?

Figura 48. Décima oitava atividade da unidade de aprendizagem "Ato I - segunda parte"

2) Ao final da cena, terão que explicar também o verso "Ah, la maledizione!", reevocando, assim, o personagem de Monterone - que constitui a próxima atividade e trazendo à baila outro tema fulcral da ópera.

Spiegate il verso "Ah, la maledizione!"

Figura 49. Décima nona atividade da unidade de aprendizagem "Ato I - segunda parte"

Extra: Para finalizar o primeiro ato, seria interessante promover uma discussão sobre as relações entre os personagens Monterone e Rigoletto. Portanto, teremos um desafio: 
os alunos terão que encontrar todas as semelhanças entre os dois personagens, buscando elementos no libreto e na cena em que Monterone aparece. Provavelmente, além das evidências dos fatos, encontrarão várias mensagens de "eu sou você amanhã”, como a passagem em que Rigoletto imita a voz de Monterone como um indício irônico da sua própria desgraça, o fato de ambos os personagens serem barítonos e, no filme, serem representados pelo mesmo ator.

Secondo voi i personaggi di Monterone e Rigoletto sono simili? Cercate nel libreto e nella scena in cui Monterone appare gli elementi che vi possano aiutare a scoprirlo!

Figura 50. Vigésima atividade da unidade de aprendizagem "Ato Isegunda parte"

Fim de ato: Novamente, levarão para casa a paráfrase de toda a segunda parte do primeiro ato dividida em parágrafos de ordem casual para que possam reordená-los. 
Riordinate i pezzi della trama della seconda parte dell'Atto I:

(1) Quella sera stessa, in una strada buia. Rigoletto ripensa alla maledizione di Monterone, temendo che le sue parole possano rivelarsi presaghe di sventura.

( ) Proprio in quel momento il Duca, che era rimasto celato in giardino, si fa avanti e dichiara a Gilda il suo amore, dicendo di essere uno studente povero di nome Gualtiero Maldé ("T'amo... $\grave{E}$ il sol dell'anima»). Dopo l'ardente duetto d'amore il Duca si allontana, e Gilda, rimasta sola, canta il suo amore per lui («Caro nome»).

( ) Da una casa della via esce in quel momento una fanciulla, gettandosi fra le sue braccia: quella che $i$ cortigiani credevano l'amante di Rigoletto, è in realtà sua figlia, Gilda (soprano). La ragazza vorrebbe sapere chi sia in realtà suo padre, quale vita conduca, e chi sia stata sua madre, che ella non ha mai conosciuto: ma per paura che possa venirle fatto del male, Rigoletto la tiene all'oscuro di tutto, e le impedisce addirittura di uscire di casa se non per recarsi in chiesa, facendola sorvegliare ed accudire dalla fida Giovanna (mezzosoprano).

( ) Egli incontra quindi il brigante Sparafucile (basso), che gli offre $i$ suoi servigi: per denaro egli è disposto ad uccidere qualsiasi nemico. Rigoletto rifiuta l'offerta, ma gli chiede comunque informazioni sul suo modo di agire, e si fa dire dove possa ritrovarlo in caso di bisogno ("Signor? Va, non ho niente»). Il buffone ripensa ancora alla maledizione del vecchio, e medita sulla sua scellerata condizione: se egli è così acido e crudele, la colpa non è sua, ma dei cortigiani che lo hanno reso tale («Pari siamo!»).

( ) Durante le ultime battute di Rigoletto, compare in giardino il Duca, che ode non visto la conversazione tra i due, e capisce quindi che Gilda è la figlia del gobbo buffone. Allontanatosi Rigoletto, Gilda confessa a Giovanna di avere dei rimorsi, per non aver raccontato al padre del giovane che da tempo la segue in chiesa.

( ) I cortigiani del Duca, intanto, hanno deciso di rapire la ragazza, credendola l'amante di Rigoletto. Il buffone proprio allora ritorna verso casa, ed i cortigiani lo convincono che essi sono li per rapire la Contessa di Ceprano: dopo averlo bendato, senza che egli se ne accorga, essi fanno reggere proprio a lui la scala che servirà loro per introdursi nella casa ("Zitti, zitti, moviamo a vendetta»). Udite le urla di sua figlia, e resosi conto della verità quando è ormai troppo tardi, Rigoletto cade a terra privo di sensi.

( ) I due si scambiano a lungo le espressioni del loro grande e reciproco amore; quindi il buffone raccomanda ancora una volta a Giovanna di vegliare sua figlia, e dato un ultimo abbraccio a Gilda si allontana.

Figura 51. Vigésima primeira e última atividade da unidade de aprendizagem "Ato I - segunda parte" 
Ato II. Cena I. O ato inicia com o Duque desolado por não ter notícias do rapto de Gilda. Entoa a ária "Ella mi fu rapita".

1) Antes de ouvir a ária, pediremos aos alunos que adivinhem a reação do Duque ao saber que Gilda foi raptada, com base no que conhecem desse personagem até aqui.

Gilda è stata rapita. Indovinate la reazione del Duca quando lo scopre.

Figura 52. Primeira atividade da unidade de aprendizagem "Ato II"

2) Após ouvi-la, deverão descrever o estado de ânimo do Duque, buscando na cena todos os elementos que os ajudem a fazê-lo, como a melodia, os gestos e eventuais palavras.

Sentite adesso l'aria del Duca e descrivete la sua reazione, cercando nella scena tutti gli elementi che lo possano confermare.

Figura 53. Segunda atividade da unidade de aprendizagem "Ato II"

3) Pela primeira vez até aqui, recorro à técnica de divisão do texto em partes, para que os alunos segmentem a ária em diversas seções e justifiquem-no. Provavelmente, a divisão será feita com base nos diferentes estados de ânimo que o personagem assume ao longo da ária - citados durante a correção da atividade anterior - ou seja, a surpresa, a desolação, a raiva ${ }_{2}$ e o desejo de vingança contra o sequestrador e também de tê-la consigo. Portanto, as justificativas deverão fazer referência aos afetos ou, pelo menos, a elementos que os relevem.

Leggete adesso attentamente l'aria "Ella mi fu rapita". In quante parti credete che la possiamo dividere? Perché?

Figura 54. Terceira atividade da unidade de aprendizagem "Ato II"

Cena II. Os cortesãos vão ao encontro do Duque para contar-lhe que raptaram a suposta amante de Rigoletto e para entregá-la a ele.

1) A atividade prevê que os alunos retornem à primeira atividade da cena $X V$, quando descrevem a façanha dos cortesãos no rapto de Gilda, e confrontem-na à descrição que 
os próprios cortesãos fazem ao Duque. O objetivo é que eles encontrem no texto de origem os elementos equivalentes à descrição dos alunos e, eventualmente, elementos novos ou diferentes. É preciso ressaltar que esta atividade só foi possível porque os próprios personagens descrevem um evento passado no discurso indireto e, portanto, realizam a mesma atividade desenvolvida pelos alunos na ocasião em que o evento aconteceu.

Prendete il vostro scritto sulla descrizione del rapimento di Gilda (prima attività della scena $X V$ ), e confrontatela alla descrizione che $i$ cortigiani ne fanno al Duca. Quali sono gli elementi equivalenti? Ci sono elementi nuovi o diversi tra l'uno e l'altro testo?

Figura 55. Quarta atividade da unidade de aprendizagem "Ato II"

2) O estado de ânimo do Duque muda subitamente após a notícia de que Gilda está sob o seu teto. Os alunos deverão, portanto, responder à pergunta que os cortesãos fazem a si mesmos no verso "Oh qual pensier or l'agita, come cangiò d'umor!”(“Oh, que pensamento agora o agita, como mudou de humor!").

Rispondete alla domanda dei cortigiani: "Oh qual pensier or l'agita, come cangiò d'umor!", trovando nella scena tutti gli elementi che avete a dispozione per farlo.

Figura 56. Quinta atividade da unidade de aprendizagem "Ato II"

Cena III. Rigoletto aparece demonstrando indiferença, mas no seu íntimo reina um enorme desespero para encontrar sua filha.

1) Esta cena certamente impele à descrição do estado de ânimo do personagem Rigoletto, que chega cantarolando "La rá, la rá, la la, la rá, la rá" para fingir indiferença e tentar descobrir onde os cortesãos esconderam Gilda. Os alunos deverão, de fato, interpretar o "la rá la", os gestos e eventuais palavras que denotem esse sentimento.

Descrivete lo stato d'animo di Rigoletto in questa scena, cercando tutti gli elementi possibili per giustificare le vostre parole.

Figura 57. Sexta atividade da unidade de aprendizagem "Ato II" 
2) Agora, com o libreto em mãos, os alunos analisarão como Rigoletto deixa entrever que a sua indiferença é apenas um disfarce. Portanto, deverão encontrar todos os versos que indiquem a sua preocupação oculta.

Adesso cercate nel libreto tutti gli elementi che ci permettono di capire il vero stato d'animo di Rigoletto.

Figura 58. Sétima atividade da unidade de aprendizagem "Ato II"

3) Esta atividade tem como objetivo levar os alunos à compreensão escrita do verso "Che dell'usato più nojoso voi siete" (Que vocês são mais entediantes do que o normal"), pela técnica de definição de vocábulos. Neste caso específico, em que se requer a sinonímia de apenas um lexema, os alunos deverão encontrar a acepção que melhor se adéque ao contexto para poder parafrasear o verso sem prejudicar seu sentido.

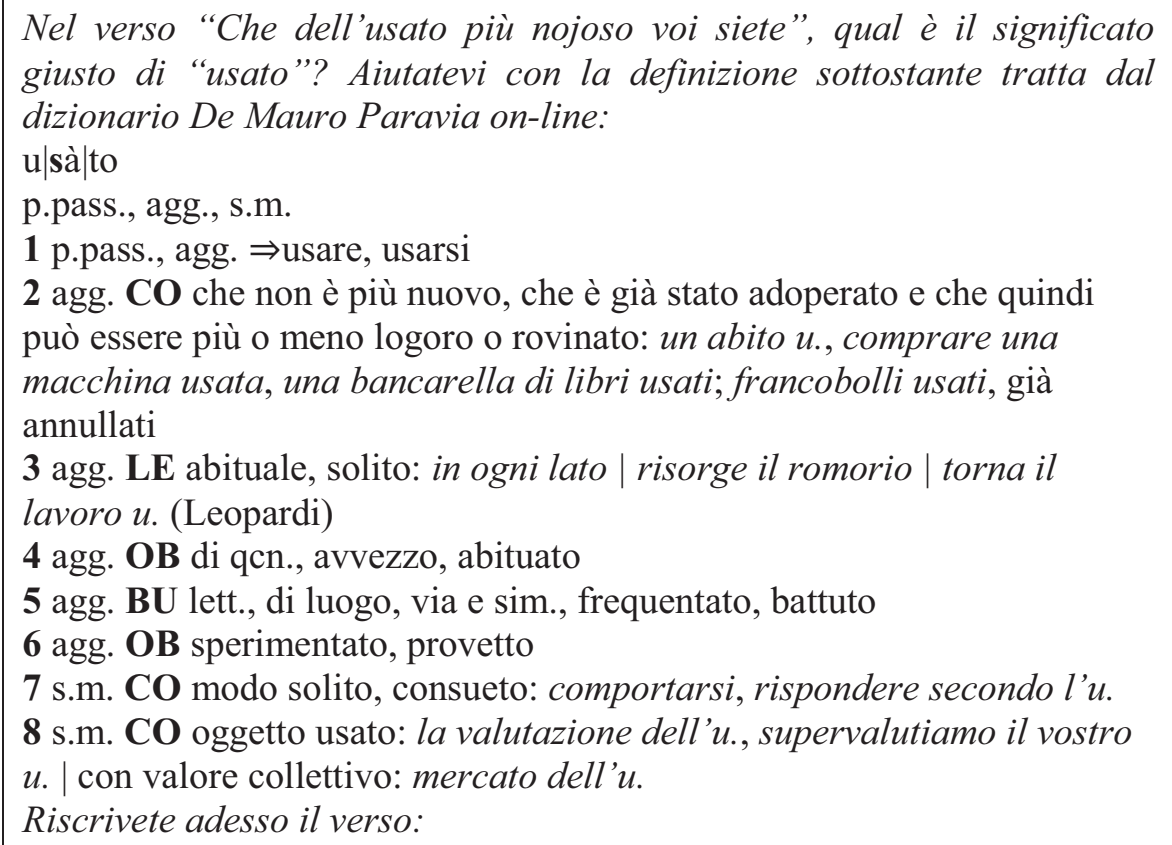

Figura 59. Oitava atividade da unidade de aprendizagem "Ato II"

Cena IV. Sem querer, com a chegada de um pajem, Rigoletto descobre que o Duque está com Gilda. Totalmente fora de si, tenta forçar seu caminho até o Duque, mas é afastado pelos cortesãos e, nesse momento, roga para que ela seja liberta. 
1) Os alunos usarão sua sensibilidade para dizer por quais afetos Rigoletto é tomado nesta cena, utilizando-se da música, dos gestos e de eventuais palavras.

Quali affetti invadono l'animo di Rigoletto in questa scena? Per risponderlo ricorrete alla melodia, ai gesti e ad eventuali parole che siete riusciti a capire.

Figura 60. Nona atividade da unidade de aprendizagem "Ato II"

2) Esta atividade é composta de algumas perguntas abertas a serem respondidas com o auxílio do libreto.

Rispondete:
a) Chi vuole parlare al Duca?
b) Quali sono le scuse inventate dai cortigiani?
c) Il paggio ci crede? Perché?

Figura 61. Décima atividade da unidade de aprendizagem "Ato II"

3) Em seguida, a atividade pede que os alunos encontrem alguns versos de Rigoletto a partir da descrição parafrástica de cada um.

Trovate $i$ versi in cui:

a) Rigoletto chiede di riavere la figlia:

b) Rigoletto si mostra consapevole della vendetta dei cortigiani:

c) Rigoletto minaccia i cortigiani:

d) Rigoletto fa appello alla bontà dei cortigiani:

Figura 62. Décima primeira atividade da unidade de aprendizagem "Ato II"

Cena V. Rigoletto reencontra Gilda e ela the diz que o Duque lhe tirou a honra.

1) A primeira atividade utiliza a técnica de completamento. 


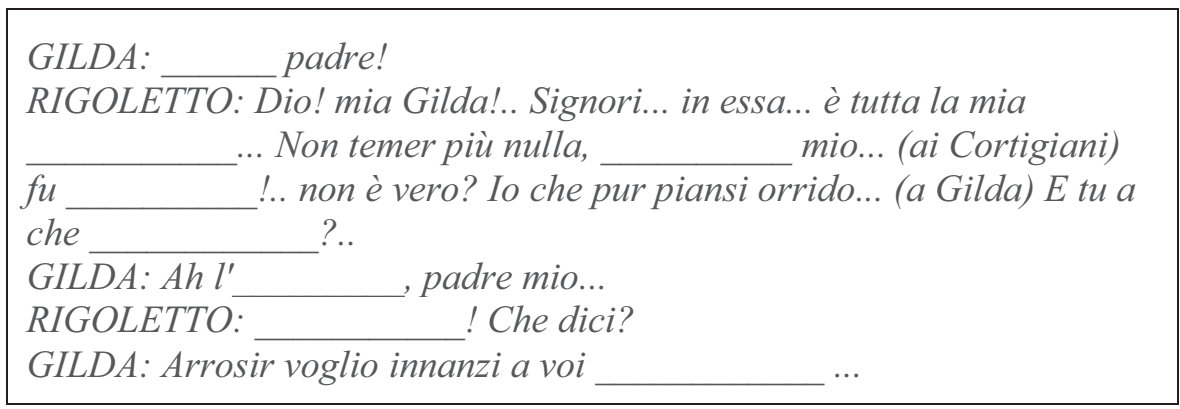

Figura 63. Décima segunda atividade da unidade de aprendizagem "Ato II"

2) Esta atividade levará os alunos à compreensão do léxico desta cena pela técnica de definição de vocábulos.

\begin{tabular}{|c|c|}
\hline \multicolumn{2}{|c|}{ Collegate le parole al loro giusto significato. } \\
\hline Scherzo & diventare rosso in \\
\hline & $\begin{array}{l}\text { volto, spec. per } \\
\text { un'emozione }\end{array}$ \\
\hline Onta & $\begin{array}{l}\text { avvicinarsi, in senso } \\
\text { spaziale o temporale }\end{array}$ \\
\hline Arrossire & $\begin{array}{l}\text { comportamento,azione, } \\
\text { espressione, discorso } \\
\text { che hanno lo scopo di } \\
\text { divertire, di suscitare } \\
\text { ilarità }\end{array}$ \\
\hline Appressarsi & $\begin{array}{l}\text { disonore, vergogna } \\
\text { derivante da un'azione } \\
\text { infamante commessa o } \\
\text { subita }\end{array}$ \\
\hline
\end{tabular}

Figura 64. Décima terceira atividade da unidade de aprendizagem "Ato II"

3) A última atividade desta cena pede que os alunos expliquem a última fala dos cortesãos: “Coi fanciulli e co' dementi spesso giova il simular. Partiam pur, ma quel ch'ei tenti non lasciamo d'osservar” (“As crianças e os dementes gostam bastante de fingir. Vamos embora, mas o que quer que ele tente, não deixemos de observar"). Assim, deverão mencionar o medo dos cortesãos de um eventual programa narrativo de vingança de Rigoletto. 
Spiegate l' ultima battuta dei cortigiani:

Borsa, Marullo, Ceprano: (tra loro) Coi fanciulli e co'dementi spesso giova il simular. Partiam pur, ma quel ch'ei tenti non lasciamo d'osservar. (partono)

Figura 65. Décima quarta atividade da unidade de aprendizagem "Ato II"

Cena VI. Gilda confessa ao pai que já conhecia o Duque.

1) Os alunos deverão resumir o conteúdo desta cena por meio de uma pergunta aberta sobre o que Gilda teria contado ao pai. Certamente, para formular as hipóteses os alunos se servirão muito da reação de Rigoletto ao ouvi-la, cuja definição constitui a próxima atividade.

Cosa avrebbe raccontato Gilda al padre?

Figura 66. Décima quinta atividade da unidade de aprendizagem "Ato II"

2) Agora, deverão escolher, dentre as palavras dispostas, as emoções que melhor definem o estado de ânimo de Rigoletto diante das palavras de Gilda.

Che emozioni prova Rigoletto davanti alle parole di Gilda? Scegliete

fra le parole sottostanti quelle che meglio le definiscono.

( ) oddio ( ) desiderio di vendetta

( ) rassegnazione () desolazione

( ) voglia di consolare ( ) speranza

Figura 67. Décima sexta atividade da unidade de aprendizagem "Ato II"

3) Ao ler o libreto, os alunos verificarão a resposta da atividade anterior, e escolherão as passagens do texto que ilustram as emoções do personagem.

Controllate adesso sul libretto se ci sono dei passaggi che illustrano le emozioni dell' attività precedente. Quali sono?

Figura 68. Décima sétima atividade da unidade de aprendizagem "Ato II" 
4) Para finalizar esta cena, os alunos analisarão alguns versos de Rigoletto e escolherão a alternativa que melhor os explicam.

Analizzate $i$ versi di Rigoletto e scegliete l'alternativa che meglio li spiega.

a) ( ) Il buffone prega Dio di togliergli la vita dopo tale infamia.

b) () Il buffone dice che preferiva vedere la figlia morta a diffamata.

c) () Il buffone aveva sempre chiesto a Dio che Gilda ricevesse tanta grazia quanta disgrazia aveva ricevuto lui.

Figura 69. Décima oitava atividade da unidade de aprendizagem "Ato II"

Cena VII. Rigoletto observa, da janela, Monterone ser levado à prisão.

1) A partir da paráfrase desta cena, os alunos deverão completar o exercício de cloze.

\section{Completate:}

Mentre Monterone viene portato in prigione dice che il Duca dovrà vivere poiché è stato in vano da lui Intanto

Rigoletto lo osserva e dice a sé stesso che il vecchio si $e$ che anzi lui avrà un vindice.

Figura 70. Décima nona atividade da unidade de aprendizagem "Ato II"

Cena VIII. Rigoletto sente-se obstinado por vingança, embora Gilda suplique perdão ao Duque.

1) Como não poderia deixar de ser, esta atividade pede que os alunos descrevam o estado de ânimo dos dois personagens, buscando na cena todos os elementos úteis para fazêlo.

Descrivete lo stato di animo dei due personaggi, cercando nella scena tutti gli elementi melodici, gestuali e eventualmente testuali per giustificare le vostre parole.

Figura 71. Vigésima atividade da unidade de aprendizagem "Ato II"

Fim de ato: Novamente, levarão para casa a paráfrase do segundo ato dividida em parágrafos de ordem casual para que possam reordená-los. 
Riordinate i pezzi della trama dell' Atto II:

(1) Un salotto nel Palazzo Ducale. Il Duca è in ansia per Gilda: spinto da uno strano presentimento era infatti tornato sui suoi passi, e si era accorto che ella era stata rapita («Ella mi fu rapita!... Parmi veder le lagrime»).

( ) Giungono frettolosamente i cortigiani, e rivelano al Duca di aver rapito l'amante di Rigoletto e di averla condotta a Palazzo: il Duca capisce che si tratta di Gilda, e si precipita nella stanza in cui i cortigiani l'hanno rinchiusa («Possente amor mi chiama»).

( ) Mentre Rigoletto consola amorevolmente la figlia, il Conte di Monterone attraversa la scena, condotto al carcere da due guardie, e constata con amarezza che la sua maledizione non ha avuto alcun effetto sul Duca. Ma il buffone gli grida che anch'egli desidera ora vendicarlo, mentre Gilda - sedotta, ma ancora innamorata del Duca - cerca di calmare la sua ira («Sì, vendetta, tremenda vendetta»).

( ) Rigoletto fa per slanciarsi verso la stanza, ma i cortigiani lo trattengono, dicendogli di trovarsi un'altra amante. Rigoletto urla allora che si tratta di sua figlia, e quindi impreca contro di loro, li minaccia; ma poi li prega, li supplica di aiutarlo, addirittura piangendo e prostrandosi ai loro piedi («Cortigiani, vil razza dannata»).

( ) Entra quindi in scena Rigoletto, fingendo indifferenza, ma in realtà attentissimo alle parole ed ai gesti dei cortigiani, per cercar di scoprire dove essi abbiano condotto Gilda. I cortigiani, naturalmente, fingono di non ricordare nulla di quella notte; ma quando entra un paggio della Duchessa (mezzosoprano), venuto per cercare il Duca, dall'imbarazzata reazione dei cortigiani il buffone comprende immediatamente che sua figlia si trova con il Duca nella stanza accanto.

( ) In quel momento Gilda esce dalla stanza e si getta tra le braccia del padre. Rigoletto allontana imperiosamente tutti i presenti per poter rimanere solo con lei, e la ragazza gli narra del suo amore con il Duca, che ella credeva uno studente, e della vergogna ora subita. («Tutte le feste al tempio»).

Figura 72. Vigésima primeira e última atividade da unidade de aprendizagem "Ato II"

Ato III. Cena I. Passado algum tempo, Rigoletto leva Gilda até a hospedaria de Sparafucile para que ela veja quem o Duque é realmente.

1) A primeira atividade refere-se à formulação de hipóteses a partir do local, da visão do personagem Sparafucile, da melodia e do próprio conjunto da cena. De fato, os alunos lançarão hipóteses sobre o plano de vingança de Rigoletto. 
Dove Rigoletto avrà portato Gilda? Perché? Cogliete dalla scena tutti gli elementi che vi possano aiutare a rispondere.

Figura 73. Primeira atividade da unidade de aprendizagem "Ato III"

2) Depois dessa pergunta abrangente de valor hipotético, as atividades versarão sobre o conteúdo específico da cena com relação ao tempo. Primeiro, os alunos deverão assinalar todas as pistas temporais encontradas no libreto, como o advérbio "sempre", o verso "pur tempo a guarirne t'ho lasciato" ("e eu te dei tempo para se curar"), os verbos "amo" e "mi adora" no presente, o período hipotético "E se tu certa fossi ch'ei ti tradisse, l'ameresti ancora?" ("E se você estivesse certa de que ele te traía, ainda o amaria?"), a expressão "ma ne avrai vendetta" ("mas você será vingada") no futuro e as expressões "osserva dunque" ("observa, então") e "per poco attendi" ("espera um pouco").

Segnate tutte le parole (avverbi e verbi) o espressioni che si riferiscono al Tempo trovate sul libretto.

Figura 74. Segunda atividade da unidade de aprendizagem "Ato III"

3) Em seguida, deverão explicar as intenções de Rigoletto pela categoria de tempo.

Adesso spiegate le intenzioni di Rigoletto attraverso le parole che avete sottolineato.

Figura 75. Terceira atividade da unidade de aprendizagem "Ato III"

Cena II. O Duque chega, pede vinho e um quarto a Sparafucile e entoa a ária "La donna è mobile".

1) A primeira atividade pede que os alunos descrevam a cena a partir dos elementos musicais, cênicos e, eventualmente, textuais que terão conseguido captar.

Descrivete la scena prendendo come spunto la musica, i gesti e qualche parola che avete capito.

Figura 76. Quarta atividade da unidade de aprendizagem "Ato III"

2) Agora, serão chamados a explicar os versos "Son questi i suoi costumi” ("São estes os seus costumes") e "Più tardi tornerò l'opra compire" ("Mais tarde voltarei para 
cumprir o trabalho"), ambos de Rigoletto. Obviamente, o dêitico "estes" e o substantivo "trabalho" aparecem como elementos inferenciais a serem arrolados pelos alunos, que deverão recorrer, respectivamente, à performance do Duque e ao PN de vingança de Rigoletto para explicá-los.

Spiegate i versi:
a) "Son questi i suoi costumi!"
b) "Più tardi tornerò l'opra compire."

Figura 77. Quinta atividade da unidade de aprendizagem "Ato III"

Extra: Esta cena parece pôr um ponto definitivo na oscilante performance do Duque de Mântua. É interessante pedir aos alunos que constatem esta oscilação por meio de uma atividade de interdiscursividade.

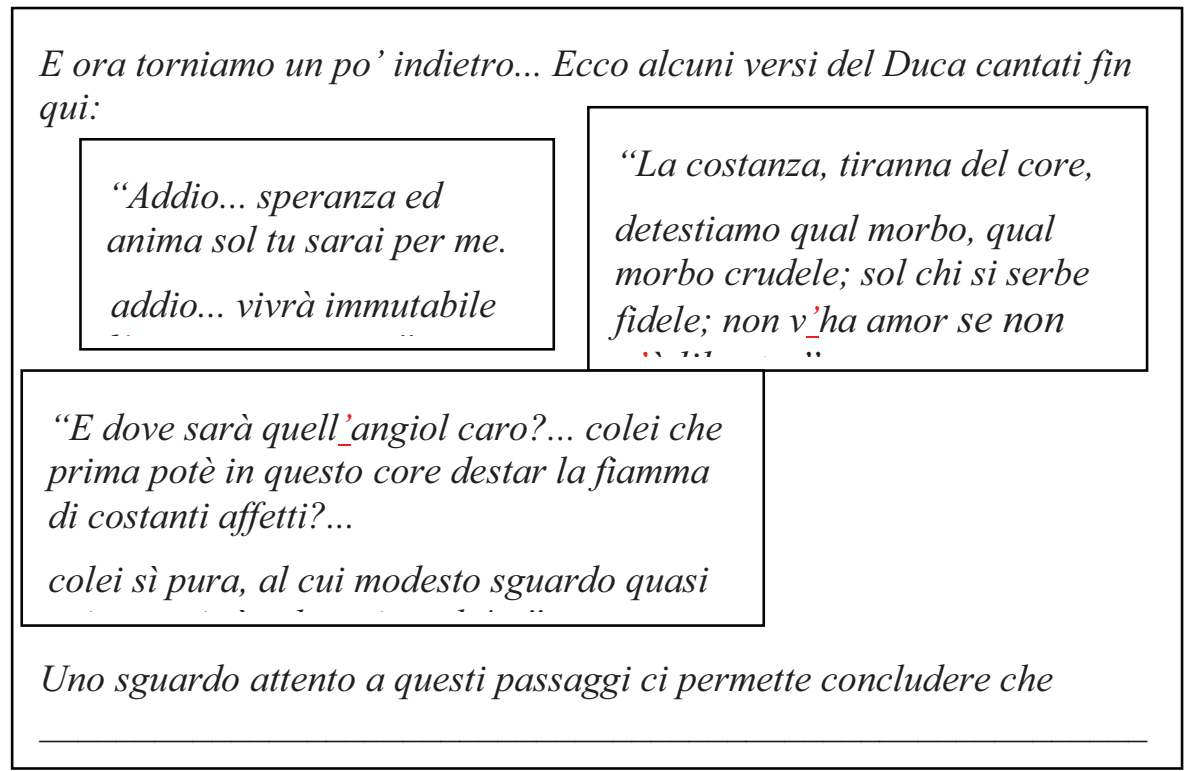

Figura 78. Sexta atividade da unidade de aprendizagem "Ato III"

Cena III. Rigoletto força Gilda a ver o flete entre Maddalena e o Duque, e os quatro personagens entoam o famoso quarteto "Bella figlia dell'amore".

1) A primeira atividade constitui uma pergunta aberta em que se requer a compreensão global da cena. De fato, os alunos deverão discorrer sobre o que Gilda vê, ou seja, eles deverão adotar o ponto de vista da personagem para descrever o que acontece na cena. 
Cosa vede Gilda?

Figura 79. Sétima atividade da unidade de aprendizagem "Ato III"

2) O verso "Or sappi, che d'allora sol te quest'alma adora" (“Agora saiba que, desde então, esta alma adora somente a ti”), do Duque para Maddalena, é uma resposta à afirmação “[...], ma pur m'adora” (“[...], mas simplesmente me adora”), de Gilda para Rigoletto neste mesmo ato, quando Gilda descobre que "perdeu" o seu objeto. A tarefa dos alunos será, portanto, encontrar o verso do Duque a partir do verso de Gilda, visando a perceber a intenção do autor a este propósito.

Con il verso "[...] ma pur mi adora" (scena I, atto III), Gilda dimostrava essere sicura dell'amore del Duca. Quale verso comprova il suo sbaglio?

Figura 80. Oitava atividade da unidade de aprendizagem "Ato III"

3) Passando à fase de compreensão escrita, os alunos procederão a um exercício de correspondência, em que deverão ligar cada fala a seu verdadeiro locutor. Além disso, a atividade prevê que encontrem o verbo justo para cada fala e insiram-no no balão. 


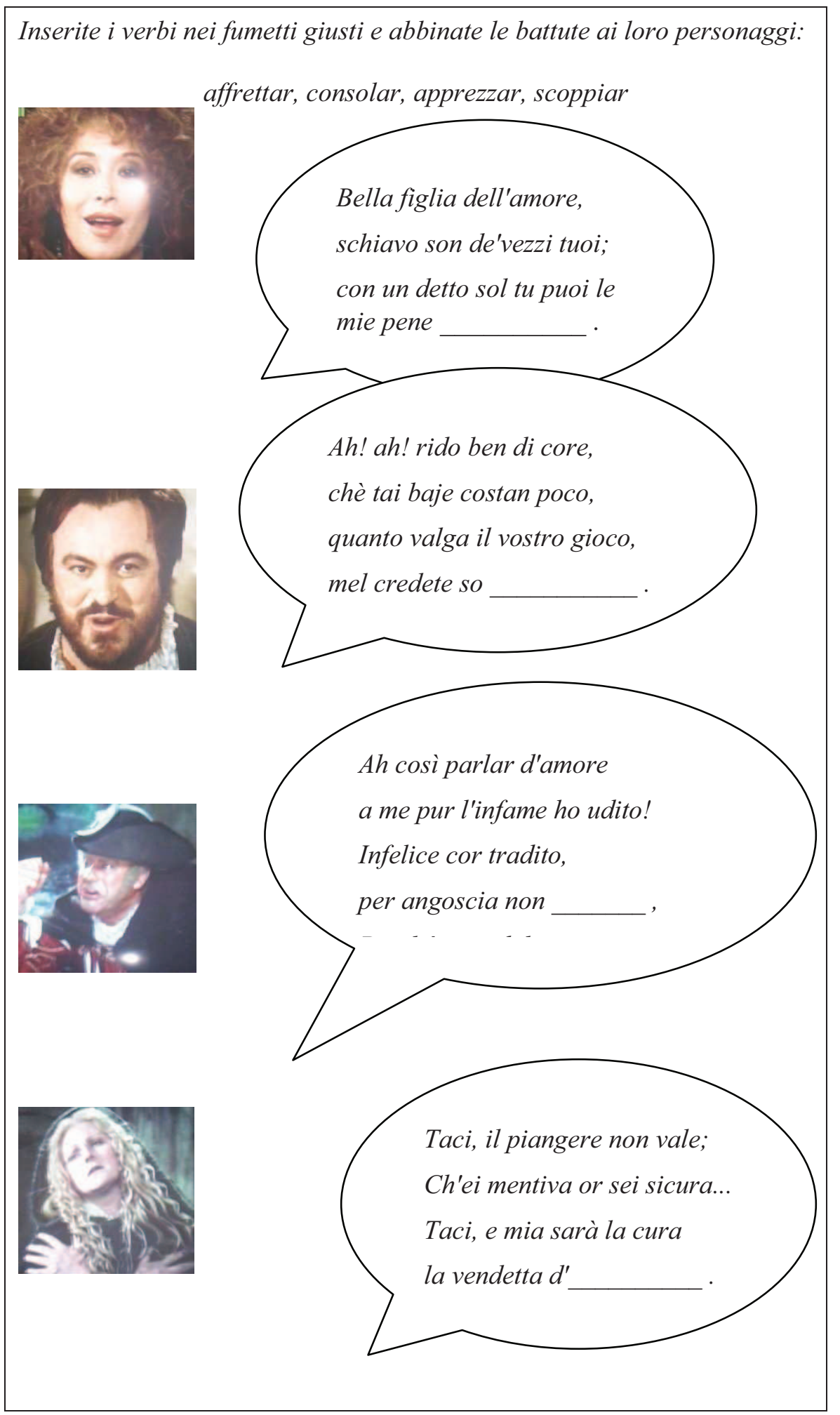

Figura 81. Nona atividade da unidade de aprendizagem "Ato III"

4) Finalmente, visando a analisar a personagem Maddalena, os alunos a deverão descrever com base no seu discurso e pela diferença de comportamento em relação a Gilda. 
Che tipo di donna è Maddalena? Descrivela cercando nella scena e nel testo gli elementi che la possano contraddistinguere.

Figura 82. Décima atividade da unidade de aprendizagem "Ato III"

Cena IV. Rigoletto combina com Sparafucile o assassinato do Duque.

1) Para esta cena foi selecionada a técnica de atualização linguística, em que os alunos dirão, dentre as palavras evidenciadas, quais formas não são utilizadas no italiano moderno e, a partir de então, procederão à atualização.

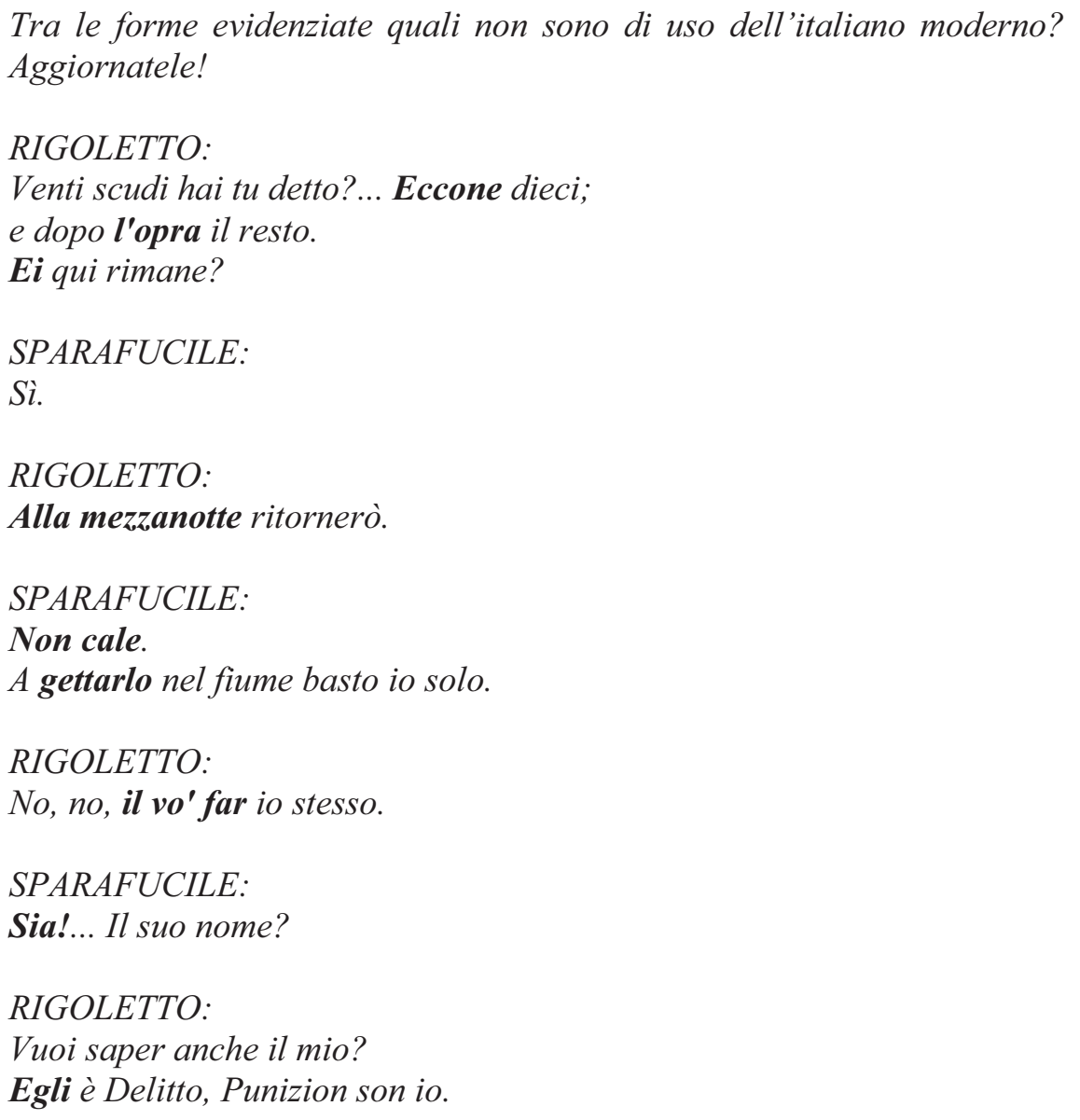

Figura 83. Décima primeira atividade da unidade de aprendizagem "Ato III"

2) No que concerne à análise textual, deverão inferir a noção de justiça para Rigoletto pela explicação do verso "Egli è Delitto, Punizion son io" ("Ele é Delito, eu sou Punição"). 
Spiegate il verso "Egli è Delitto, Punizion son io".

Figura 84. Décima segunda atividade da unidade de aprendizagem "Ato III"

Cena V. Chove muito, e Sparafucile leva o Duque para repousar em seu quarto. Sozinho com Maddalena, fala-lhe sobre o plano de assassiná-lo.

1) Maddalena já dá indícios de opor-se à ação do irmão. Os alunos deverão descrever o estado de ânimo da personagem, encontrando na cena todos os elementos que os ajudem a fazê-lo.

Descrivete lo stato di animo di Maddalena in questa scena, prendendone tutti gli elementi che vi aiutino a farlo.

Figura 85. Décima terceira atividade da unidade de aprendizagem "Ato III"

2) Esta cena traz muitas referências ao tempo ruim, já preanunciado na cena anterior por um raio. Metaforicamente, esses versos inferem um acontecimento ruim, ou seja, o iminente homicídio. Portanto, os alunos deverão identificar a metáfora do tempo, encontrando na cena todos os indícios (explícitos e implícitos) sobre o assassinato do Duque.

Trovate nella scena tutti gli indizi (espliciti e impliciti) sull'omicidio del Duca.

Figura 86. Décima quarta atividade da unidade de aprendizagem "Ato III"

Cena VI. Gilda não obedece às ordens do pai de ir partir para Verona e volta à taberna de Sparafucile. Do lado de fora, ouve os irmãos discutirem sobre o assassinato do Duque. Maddalena persuade Sparafucile a matar outra pessoa em seu lugar, e Gilda resolve se sacrificar por seu amado.

1) Esta cena possui muitas ações e, portanto, o ideal é pedir que os alunos as identifiquem.

Raccontate tutto quello che succede in questa scena.

Figura 87. Décima quinta atividade da unidade de aprendizagem "Ato III" 
2) Em seguida à nossa frequente técnica de descrição, pediremos aos alunos que individuem os programas narrativos de cada personagem por meio de perguntas abertas sobre o que cada personagem faz e por quê.

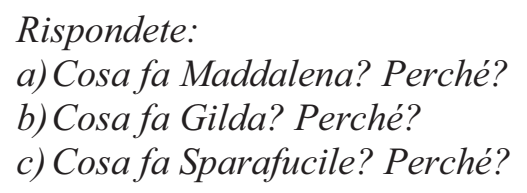

Figura 88. Décima sexta atividade da unidade de aprendizagem "Ato III"

3) Enfim, deverão encontrar os versos que correspondem aos enunciados de fazer ou de /fazer-fazer/ de cada personagem nesta cena:

Trovate $i$ versi in cui:

a) Sparafucile racconta cosa farà col Duca:

b) Maddalena gli propone un piano:

c) Sparafucile lo rifiuta:

d) Maddalena allora dice come impedirà l'uccisione del Duca:

e) Sparafucile dice che se qualcuno appare può morire al posto suo:

f) Gilda decide di morire per lui:

g) Sparafucile ordina alla sorella di aprire la porta:

h) Gilda chiede perdono a Dio per la sua decisione:

Figura 89. Décima sétima atividade da unidade de aprendizagem "Ato III"

Cena VII. Sparafucile e Maddalena escondem a vítima em um saco, e Rigoletto retorna ansioso por ver seu plano de vingança concretizado.

Nesta cena, o enunciador articula a categoria de tempo ao estado do sujeito da seguinte maneira: quanto maior o tempo da espera, maior o sofrimento do sujeito ("da trenta dì l'aspetto/ di vivo sangue a lagrime piangendo, / sotto la larva del buffon...") - ("há trinta dias espero / de vivo sangue a lágrimas chorando, / sob a máscara do bufão...”). Em contrapartida, quanto mais próximo o sujeito está do fim da espera, maior a sua euforia ("Dalla vendetta alfin giunge l'istante [...] / Oh, come in vero qui grande mi sento!..) - ("Da vingança finalmente chega o instante [...] / Oh, como, literalmente, grande aqui me sinto!..”). Além disso, podemos entrever a ansiedade do sujeito diante da espera quase, mas não totalmente, 
finda (“Ah, non è tempo ancor!.. S'attenda") - (“Ah, não é tempo ainda!.. Que se espere”). As atividades propostas para esta cena são:

1) Primeiro, os alunos descreverão o estado de ânimo de Rigoletto a partir de todos os elementos que compõem a cena.

Descrivete lo stato d'animo di Rigoletto tenendo conto di tutti gli elementi che compongono la scena.

Figura 90. Décima oitava atividade da unidade de aprendizagem "Ato III"

2) O segundo passo é fazer com que eles separem em uma tabela todos os versos eufóricos dos versos disfóricos do texto e, em seguida, interpretem os dados estabelecendo um paralelo entre o tempo e o estado de ânimo do personagem nas duas situações.

Separate in questa tabella tutti i versi positivi e negativi trovati nel testo, come nell'esempio:

\begin{tabular}{|l|l|}
\hline Versi positivi & Versi negativi \\
\hline $\begin{array}{l}\text { Dalla vendetta alfin giunge } \\
\text { l'istante }\end{array}$ & da trenta di l'aspetto \\
\hline
\end{tabular}

Come possiamo interpretare questi dati? Stabilite un parallelo tra il tempo e lo stato d'animo del personaggio nelle due situazioni.

Figura 91. Décima nona atividade da unidade de aprendizagem "Ato III"

Cena VIII. Sparafucile entrega o saco com o corpo de Gilda a Rigoletto.

1) Para esta cena, muito curta, teremos duas perguntas abertas sobre o que Rigoletto pretende fazer com o suposto corpo do Duque e quais os conselhos que recebe de Sparafucile.

Rispondete:

a) Cosa intende fare Rigoletto con il presunto corpo del Duca?

b) Quali consigli riceve da Sparafucile?

Figura 92. Vigésima atividade da unidade de aprendizagem "Ato III" 
Cena IX. Muito feliz por estar concretizando sua vingança, Rigoletto está ansioso por jogar o saco no rio, quando, para seu horror, ouve a voz do Duque ao longe cantarolando.

1) Nesta cena, o estado de ânimo de Rigoletto passa subitamente do extremo eufórico ao extremo disfórico assim que ele ouve a voz longinqua do Duque. Os alunos deverão atinar a essa mudança, escolhendo da cena os elementos para explicá-la.

Come cambia lo stato d'animo di Rigoletto in questa scena? Perché?

Figura 93. Vigésima primeira atividade da unidade de aprendizagem "Ato III"

2) Com os versos que profere, Rigoletto deixa transparecer que a dimensão da sua vingança ultrapassa a esfera familiar. Portanto, esta atividade prevê que os alunos infiram o significado pleno de "Ora mi guarda, o mondo!.. / Quest'è un buffone, ed un potente è questo! / Ei sta sotto i miei piedi!... è desso! oh gioja!... / È giunta alfine la sua vendetta, o duolo!..” (“Agora olhe-me, oh mundo!.. / Este é um bufão, e um potente é esse! / Ele está sob os meus pés!.. está morto! oh alegria!.. / Chegou, finalmente, a sua vingança, oh dor!..”).

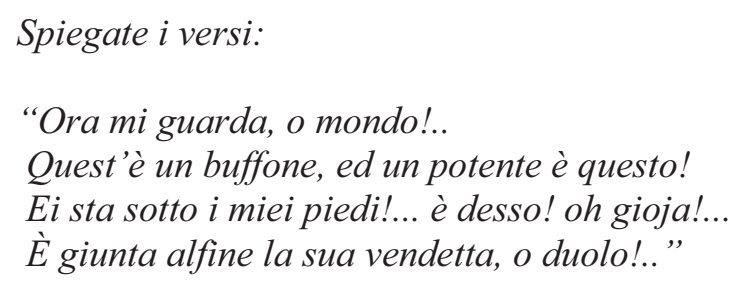

Figura 94. Vigésima segunda da unidade de aprendizagem "Ato III"

3) Para concluir esta cena, os alunos deverão discorrer sobre a nova função que "La donna è mobile" adquire neste contexto. De fato, apenas agora a canção do Duque "se revela aquilo que é: uma obra-prima de ironia trágica, já que só o caráter trivial da música lhe consente em destoar com tanta força no contexto dramatúrgico". ${ }^{162}$

\footnotetext{
162 "Solo a questo punto La donna è mobile si rivela per quello che è: un capolavoro di ironia tragica, giacché solo il carattere triviale della musica le consente di stridere con tanta forza nel contesto drammaturgico". WIKIPÉDIA. Enciclopédia virtual. Disponível em: $<$ http://it.wikipedia.org/wiki/La_donna_\%C3\%A8_mobile>. Acesso em: jul 2009.
} 
Quale funzione ha la canzone "La donna è mobile" in questa scena? Secondo voi è simile o diversa dalla funzione acquisita alla scena II? Perché?

Figura 95. Vigésima terceira atividade da unidade de aprendizagem "Ato III"

Extra: Antes de passar à última cena, os alunos deverão inventar o diálogo final entre Rigoletto e Gilda agonizando em seus braços, além de prever o último verso do bufão.

a) Usate l'immaginazione e inventate l'ultimo dialogo tra Rigoletto e Gilda che agonizza tra le sue braccia.

b) E l'ultimo verso sarà:

Figura 96. Vigésima quarta atividade da unidade de aprendizagem "Ato III"

Cena X. Gilda implora o perdão de Rigoletto e morre. Rigoletto está transtornado, infeliz, pois a maldição de Monterone foi cumprida.

1) Primeiro, os alunos deverão perpassar os tópicos do diálogo original sem o auxílio do libreto.

Cosa si sono detti padre e figlia nella scena?

Figura 97. Vigésima quinta atividade da unidade de aprendizagem "Ato III"

2) Para concluir, deverão encontrar os versos em que Rigoletto interpreta o acontecido, ou seja, "Ella stessa fu colta dallo stral di mia giusta vendetta" ("Ela própria foi atingida pela flecha da minha justa vingança") e "Ah, la maldizione", e justificar suas escolhas.

Trovate $i$ versi in cui Rigoletto interpreta quello che è successo. Non dimenticate di giustificare le vostre scelte!

Figura 98. Vigésima sexta atividade da unidade de aprendizagem "Ato III"

Final de Ato. Para finalizar a unidade de aprendizagem "Ato III", os alunos deverão, mais uma vez, reorganizar os parágrafos da paráfrase abaixo. 
Riordinate i pezzi dell'Atto III:

( 1 ) Una casa mezzo diroccata sulla riva destra del Mincio, un mese dopo. Rigoletto ha condotto Gilda nei pressi della casa in cui Sparafucile abita con la sorella Maddalena (contralto), per mostrarle che il Duca non l'ama affatto ed è invece sensibile alle lusinghe della sorella del bandito.

( ) Canticchiando il suo motivetto, il Duca va intanto a dormire, mentre si odono i primi tuoni di un temporale che si avvicina. Maddalena, però, si è invaghita del giovane sconosciuto, e prega il fratello di non ucciderlo («è amabile invero cotal giovinotto»). Il fratello esita, perché non vuol venire meno alla parola data a Rigoletto, e soprattutto perché non vuol perdere il denaro promessogli; alla fine, però, cede alle insistenti preghiere della sorella, e decide di uccidere al suo posto il primo viandante che passerà per la strada e busserà alla loro porta.

( ) Rigoletto ordina a Gilda di indossare degli abiti maschili e di partire subito per Verona, dove egli la raggiungerà al più presto, e si incontra poi con Sparafucile per perfezionare il suo contratto: in cambio di venti scudi questi ucciderà il Duca e gli consegnerà il cadavere chiuso in un sacco, per gettarlo nel fiume.

( ) Non visti, i due odono infatti giungere il Duca, che canta un allegro e sprezzante motivetto («La donna è mobile»). Sparafucile esce intanto dalla casa e si avvicina a Rigoletto per chiedergli se vuole che il suo uomo viva oppure muoia, ma il buffone gli dice di ritornare più tardi per avere una risposta.

( ) Mentre il temporale si fa sempre più minaccioso, Gilda, in abiti maschili, si avvicina alla casa, ed ode non vista i progetti dei due briganti. Ella è ancora innamorata del Duca, e decide quindi di bussare alla porta, sacrificando volutamente la sua vita per salvare quella del suo amato.

( ) Il Duca incomincia a corteggiare la ragazza, e nel quartetto che segue odiamo mescolarsi le schermaglie amorose tra lui e Maddalena con il dolore di Gilda e la determinazione di vendetta di Rigoletto («Bella figlia dell'amore»).

( ) Il temporale giunge al suo culmine, e Gilda entra nella casa dove verrà uccisa dai due briganti. A mezzanotte ritorna Rigoletto, per pagare il prezzo concordato e per ritirare il sacco con il cadavere del Duca; ma mentre si allontana per gettare il sacco dove l'acqua è più profonda, ode in lontananza lo sprezzante motivetto del Duca. Terrorizzato, apre il sacco, ed alla luce dei lampi scorge il volto di Gilda. Prima di esalare l'ultimo respiro, ella trova ancora la forza di chiedergli perdono, e gli promette che pregherà per lui dal cielo («Mia figlia!... Dio!... Mia figlia!...). Disperato, Rigoletto cade svenuto sul corpo esanime della ragazza.

Figura 99. Vigésima sétima atividade da unidade de aprendizagem "Ato III" 
Extra. Após o trabalho com toda a ópera, os alunos serão chamados a refletir novamente sobre o tema da "mobilidade do ser", mas, desta vez, consideraremos as transformações internas, ao invés das transformações superficiais das personagens.

Secondo voi è possibile identificare nell'opera dei personaggi che abbiano subito una trasformazione interna? Chi sarebbe più mobile in questo senso? Motivate le vostre risposte!

Figura 100. Vigésima oitava e última atividade da unidade de aprendizagem "Ato III"

Contexto social-histórico. As atividades reunidas nesta unidade de aprendizagem tentam dar conta do contexto em que a ópera Rigoletto foi pensada e produzida pelos seus autores ${ }^{163}$.

1) A partir das cartas trocadas entre Giuseppe Verdi, Francesco Maria Piave e o presidente do Teatro La Fenice, Carlo Marzari, os alunos terão a oportunidade de conhecer as motivações dos autores, as resistências à censura e as modificações na obra durante todas as fases da adaptação de Le Roi s'amuse, de Victor Hugo ${ }^{164}$. A atividade propõe que os alunos encontrem nas cartas as respostas para as seguintes perguntas:

a) Por que Verdi decidiu adaptar o espetáculo Le Roi s'amuse, de Victor Hugo?

b) Como deveriam se chamar as personagens principais?

c) Que título estava previsto? Por quê?

d) Por que a censura quis proibir a ópera?

e) Como Verdi conseguiu resolver o problema?

\footnotetext{
${ }^{163}$ Para além das atividades desta unidade de aprendizagem, considera-se que o contexto sócio-histórico de Rigoletto seja abordado com bastante propriedade nas atividades de intertextualidade e, de um modo geral, durante toda a unidade didática. De fato, o contato com a língua autêntica permite que os alunos descubram as marcas formais da linguagem operística romântica, além de todas as marcas que legitimam a presença de um sujeito da enunciação sócio-histórico.

${ }^{164}$ As cartas encontram-se no anexo C.
} 
Ecco alcuni brani delle lettere che Verdi, Piave e Marzari, presidente della Fenice, si sono scambiati durante la composizione di Rigoletto. Sono tratte da La genesi di Rigoletto - Un viaggio nell'epistolario verdiano, di Vincenzo Raffaele Segreto (www.teatroregioparma.org).

Rispondete:

a) Perché Verdi ha deciso di adattare lo spetacolo Le Roi s'amuse, di Victor Hugo?

b) Come dovevano chiamarsi i personaggi principali?

c) Che titolo era stato previsto? Perché?

d) Perché la censura ha voluto vietare l'opera?

e) Come é riuscito Verdi a risolvere il problema?

Figura 101. Primeira atividade sobre a unidade de aprendizagem "Contexto social-histórico"

1) Dois anos mais tarde, em 1853, Verdi e Piave estavam novamente unidos na composição de La Traviata, baseada na obra de Alexandre Dumas, A dama das camélias. Em seu texto, Verdi inclui o verso "Sia pure ma volubil sovente è l'uom" (“Que seja, mas frequentemente volúvel é o homem”), como uma resposta do personagem Giorgio Germont às hesitações da cortesã Violetta Vallery em abandonar seu filho.

A ideia é promover um debate sobre os motivos que os levaram a escrevê-lo. Primeiro, os alunos deverão adotar uma posição quanto à pregunta "Verdi e Piave foram contraditórios em escrever o referido verso?”. Em seguida, deverão motivar suas respostas e discuti-las em pequenos grupos. Ao final da atividade, toda a classe debaterá sobre as intenções do autor em ambas as afirmações.

Due anni dopo l'esordio di Rigoletto Verdi e Piave compongono La Traviata, opera basata sul romanzo Le dame aux camélias, di Alexandre Dumas. In quel testo leggiamo il verso "Sia pure ma volubil sovente è l'uom", infatti una risposta del cavaliere Giorgio Germont alle esitazioni della cortigiana Violetta Vallery di abbandonare suo figlio.

Secondo voi gli autori sono stati contraddittori nello scriverlo? Motivate le vostre risposte e discutetene in piccoli gruppi.

Figura 102. Segunda atividade sobre a unidade de aprendizagem "Contexto social-histórico"

2) E para concluir esta unidade de aprendizagem, o personagem Rigoletto será confrontado a outros dois personagens principais que compõem a trilogia romântica de 
Giuseppe Verdi, ou seja, a supracitada Violetta Valery e a cigana Azucena de Il Trovatore (1853). Os alunos deverão encontrar, por meio de uma pesquisa feita em casa (utilizando a internet), as características que aproximam as três personagens, o que explicaria o fato de estarem reunidas na chamada "trilogia verdiana".

\section{Rigoletto e la trilogia romantica di Giuseppe Verdi}

Sapete che Rigoletto fa parte di una trilogia insieme a La Traviata e $\mathrm{Il}$ Trovatore? Infatti, le tre opere prodotte tra il 1851 e il 1853 formano la trilogia romantica di Giuseppe Verdi. Ma chi sono i suoi personaggi principali? Che caratteristiche li accomunano? Scopritelo a casa, con l'aiuto dell'internet, e portate in classe il risultato delle vostre ricerche!

Figura 103. Terceira e última atividade sobre a unidade de aprendizagem "Contexto social-histórico"

\subsection{O GLOSSÁRIO ${ }^{165}$}

Ao final da apostila, os alunos encontrarão um glossário com todos os termos operísticos empregados durante o curso. Sua utilização busca responder à necessidade de compreensão da terminologia exposta nos enunciados, no libreto e à qual o professor poderá recorrer durante a verificação das atividades.

Neste sentido, o recurso visa a facilitar também a comunicação entre professor e aluno nas aulas, considerando que todo diálogo que versa uma especialidade pressupõe um conhecimento lexical mínimo constituidor do próprio código linguístico comum entre seus interlutores.

É importante reiterar que o glossário, assim como foi pensado, não constiui um material à parte e, portanto, não deve ser reutilizado em outras apostilas. Ao contrário, está intrinsecamente relacionado ao curso "Rigoletto: per gli amanti della lingua e della cultura italiana", como atesta a presença do termo "perigordino", um tipo específico de dança

\footnotetext{
${ }^{165}$ O glossário utilizado no curso "Rigoletto: per gli amanti della lingua e della cultura italiana" encontra-se no anexo D.
} 
francesa sem qualquer pertinência para a terminologia operística, mas, por outro lado, fundamental dentro do drama Rigoletto ${ }^{166}$.

Pelo mesmo motivo, muitos termos centrais para a terminologia operística que não possuem relevância ou não existem em Rigoletto não constam no glossário, como é o caso de "falsetto" ou "singspiel", por exemplo.

Quanto à forma, a entrada dos termos obedece à ordem alfabética, e a estrutura dos verbetes é simplificada em função do caráter didático do glossário. Podemos ilustrar a microestrutura de cada lexema com o quadro abaixo:

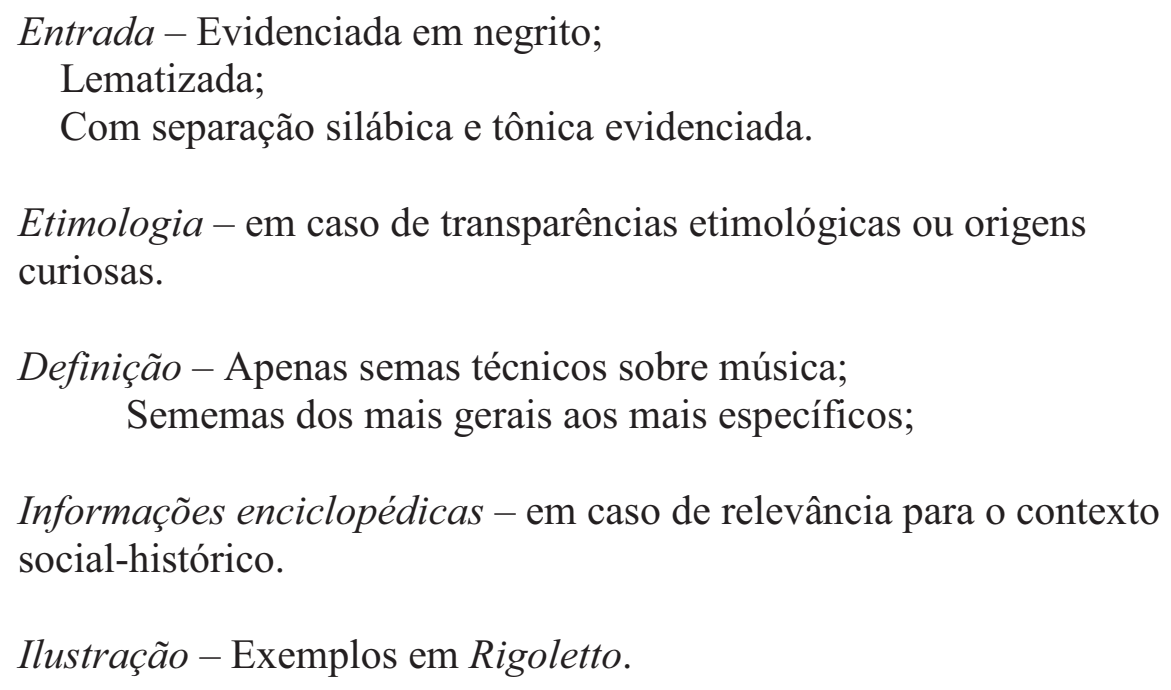

Figura 104. Microestrutura dos lexemas do glossário

É importante que, logo no início do curso, o professor mostre o glossário aos alunos e esclareça a sua função de consulta nas aulas, de modo que, já a partir da primeira unidade de aprendizagem, todos possam usufruir de suas vantagens.

\subsection{AVALIAÇÃO}

\footnotetext{
${ }^{166}$ É pela informação sobre a época em que surgiu este tipo de dança que se verifica a sua pertinência para o drama Rigoletto. De fato, o "perigordino" pode ser lido como uma marca da enunciação de que o drama do bufão, ao contrário do que a censura determinou, não se passa no século XVI, mas no século XVIII.
} 
A avaliação do curso "Rigoletto: per gli amanti della lingua e della cultura italiana" não se restringirá a um único momento privilegiado, representado pela prova ou pelo teste avaliatório aplicado ao final do curso. Ao contrário, acompanhará todo o processo de aprendizagem da ópera, para que possa medir e melhorar continuamente o desempenho dos alunos.

Desse modo, a avaliação deve ser entendida como um instrumento de feedback contínuo para todos os participantes do curso, que encontrarão na própria consecução do trabalho com a ópera os procedimentos necessários para considerar o grau de conhecimento adquirido em relação aos temas, ao enredo e a todos os componentes da obra.

De fato, podemos considerar que a aprendizagem de uma cena depende, em grande parte, da aprendizagem da cena anterior a essa, ao mesmo tempo em que prepara o aluno para uma melhor aprendizagem da cena posterior, numa espécie de efeito dominó. Assim, é justo afirmar que as atividades de cada cena funcionam também como atividades avaliatórias da cena anterior e, portanto, a avaliação do desempenho dos alunos é naturalmente consecutiva e contínua do início ao fim do percurso.

Além disso, todas as atividades que retomam os temas, o enredo, ou que colaboram para a construção de um tema ou de um personagem, por exemplo, também avaliam o processo de aprendizagem dos alunos, já que dependem de um conhecimento prévio sobre o componente em questão.

Ao final do processo, porém, os alunos serão submetidos a avaliações com nota, visando ao registro das informações relativas ao seu desempenho e a um diálogo mais objetivo entre professor e aluno e também entre os próprios alunos.

A primeira prova, que poderá ser realizada após o término da unidade de prendizagem sobre o contexto social-histórico - a duração prevista é de $1 \mathrm{~h}$ - é composta de questões dissertativas e alguns testes sobre o conteúdo de Rigoletto.

A proposta inclui cinco atividades (cada uma valendo dois pontos) relativas a tudo o que se propõe avaliar no curso, ou seja, a língua, a música, o pathos dos atores, a relação entre as linguagens artísticas, os temas, o enredo, as personagens e o contexto social-histórico.

1) A primeira atividade se refere ao léxico da ária "Questa o quella per me pari sono". A atividade utiliza a técnica do cloze facilitado e pede que os alunos insiram as palavras que se encontram abaixo do enunciado em seus respectivos espaços. Cada acerto vale 0,2 pontos. 
Inserite le parole sottostanti nella prima aria del Duca di Mantua.

costanza, ne, amanti, meglio, lo, pari, mariti, chi, gradita, crudele

"Questa o quella per me sono

a quant'altre d'intorno, d'intorno mi vedo;

del mio core l'impero non cedo ad una che ad altra beltà.

La costoro avvenenza è qual dono

di che il fato infiora la vita

se oggi questa mi torna

forse un'altra, forse un'altra, doman sarà.

La , tiranna del core,

detestiamo qual morbo, qual morbo

sol vuole si serbe fidele;

non v'ha amor, se non v'è liberta.

Dei__ il geloso furore

Degli _le smanie derido

Anco d'Argo i cent'occhi disfido

Se mi punge, se mi punge una qualche beltà,

Se mi punge una qualche beltà."

Figura 105. Primeira atividade da prova do curso "Rigoletto: per gli amanti della lingua e della cultura italiana"

2) A segunda atividade se refere à mesma ária e pede que se responda às seguintes questões:

a) Como podemos definir a música desta ária? Acelerada? Lenta? $(0,5)$

b) Quais sentimentos o Duque experimenta neste momento? $(0,5)$

c) Você saberia citar outra ária do Duque com a música diferente? (Se não lembrar o nome, explique o contexto em que se insere!) $(0,5)$

d) Quais são os sentimentos do Duque neste outro caso? $(0,5)$

Rispondete:

a) Come possiamo definire la musica di questa aria? Accelerata? Lenta?

b) Quali sentimenti prova il Duca in questo momento?

c) Sapresti citare un'altra aria del Duca con la musica distinta? (Se non ti ricordi il titolo puoi dire il contesto in cui si trova!)

d)E quali sono i sentimenti del Duca in quel caso?

Figura 106. Segunda atividade da prova do curso "Rigoletto: per gli amanti della lingua e della cultura italiana" 
3) A terceira atividade também prevê o reconhecimento da relação entre a velocidade da música e os sentimentos do personagem. Desta vez, porém, os alunos deverão explicá-la a partir da ária "La donna è mobile". A questão vale 2,0.

Il rapporto tra la velocità musicale dell'aria e i sentimenti del personaggio si verifica anche nell'aria "La donna è mobile"? Spiegalo!

Figura 107. Terceira atividade da prova do curso "Rigoletto: per gli amanti della lingua e della cultura italiana"

4) A quarta atividade pede que os alunos enumerem os acontecimentos do drama em ordem cronológica. Cada acerto vale $0,2 .{ }^{167}$

Metti in ordine cronologico gli avvenimenti del dramma:

( ) Rigoletto deride il Conte.

( ) Monterone viene portato in prigione.

( ) Rigoletto porta Gilda all'osteria di Sparafucile.

( ) Gilda e il Duca si trovano per la prima volta.

( ) Gilda racconta al padre sul suo amore segreto.

( ) Sparafucile uccide Gilda.

( ) Il Conte di Ceprano e i cortigiani si vendicano di Rigoletto.

( ) Maddalena e il Duca si trovano per la prima volta.

( ) Rigoletto contratta i servizi di Sparafucile.

( ) Il Duca fa la corte alla Contessa di Ceprano.

Figura 108. Quarta atividade da prova do curso "Rigoletto: per gli amanti della lingua e della cultura italiana"

5) A quinta e última atividade implica o conhecimento do contexto em que a ópera foi produzida pela técnica de "verdadeiro" ou "falso". As afirmações falsas devem ser reescritas e convertidas em afirmações verdadeiras. ${ }^{168}$

\footnotetext{
${ }^{167}$ Para a correção, o professor deve considerar a posição de uma frase em relação às demais, e não a sua efetiva numeração. De outro modo, um erro acarretaria no erro de todas as outras frases.

${ }^{168} \mathrm{O}$ aluno só obterá 0,5 nas afirmações falsas se conseguir convertê-las em afirmações verdadeiras. Caso contrário, obterá apenas 0,25 .
} 
Giudicate le affermazioni "vere" o "false".

a) ( ) Il dramma di Rigoletto succede nel XVIII secolo.

b) ( ) Il Teatro La Fenice ha prenotato l'opera Rigoletto a Giuseppe Verdi.

c) ( ) Il titolo originale, Le Roi s'amuse (Il re si diverte), avrebbe causato problemi alla censura dell'epoca.

d) ( ) Rigoletto fa parte della Trilogia Romantica di Giuseppe Verdi insieme a La Traviata e Ernani.

Adesso trasformate in vere le affermazioni false!

Figura 109. Quinta atividade da prova do curso "Rigoletto: per gli amanti della lingua e della cultura italiana"

A segunda avaliação com nota é uma prova prática. Os alunos assistirão a toda a ópera Rigoletto (sem legenda e sem libreto), farão uma autoavaliação do conteúdo apreendido e darão a si mesmo uma nota de zero a dez. Embora o método possa parecer pouco criterioso, devemos convir que o aluno é a pessoa mais indicada para considerar o seu próprio grau de entendimento em relação ao objeto.

Para calcular a média final do curso, o professor deverá somar o resultado da primeira avaliação ao resultado da segunda avaliação e dividir por dois.

A última avaliação apreciará, enfim, o próprio curso. Os alunos responderão a um questionário sobre o material apresentado e a metodologia aplicada. Poderão, também, tecer comentários gerais sobre o curso. ${ }^{169}$

\subsection{OS RESULTADOS}

Os resultados apresentados neste item se referem à avaliação da primeira versão do curso "Rigoletto: per gli amanti della lingua e della cultura italiana", obtidos por meio dos questionários entregues aos alunos ao final do curso. ${ }^{170}$

\footnotetext{
${ }^{169}$ Os comentários dos alunos encontram-se redigidos no tópico seguinte.

${ }^{170}$ Em virtude das modificações operadas na apostila do curso, os resultados apresentados servem apenas de base para demonstrar a eficácia da versão final descrita neste projeto.
} 
Em linhas gerais, o questionário pedia aos alunos que fizessem uma autoavaliação do seu desempenho no curso e que expressassem a sua valoração pela ópera estudada e pelo curso.

A primeira questão pedia-lhes que avaliassem o curso a partir da escolha de um conceito pré-indicado. Deveriam optar entre "excepcional", "ótimo", "interessante", "bom", "regular" ou "péssimo". Dentre os dezesseis questionários entregues, cinco alunos escolheram o adjetivo "excepcional". Os demais onze alunos acharam o curso "ótimo".

Em seguida, deveriam mencionar os pontos positivos e negativos do curso. Os pontos positivos mais citados foram:

- O material audiovisual apresentado;

- O material didático elaborado;

- O trabalho didático dividido em cenas;

- A análise atenta de cada cena;

- A oportunidade de conhecer a ópera e a cultura italiana;

- A ópera escolhida;

- A oportunidade de aprender e praticar a língua italiana;

- A dedicação e segurança do professor.

Os pontos negativos verificados na primeira versão do curso foram:

- A falta de infraestrutura das salas de multimídia disponibilizadas pelo Departamento;

- A dificuldade de se acompanhar o curso em caso de ausência na aula anterior;

- O tempo reduzido do curso;

- O tempo reduzido dedicado à realização das atividades;

- Dois alunos lamentaram não terem visto a ópera por completo ao final do curso.

A próxima questão pedia que os alunos indicassem livremente, em percentual, a sua compreensão da ópera Rigoletto. Seis alunos disseram ter entendido 100 por cento do drama; 
cinco alunos indicaram percentuais entre 95 e 90 por cento; dois, entre 85 e 80 por cento; e os três restantes indicaram ter compreendido entre 75 e 70 por cento.

Outros dados significativos demonstram o alcance dos objetivos de atitude. De fato, os alunos foram unânimes em afirmar que o curso contribuiu efetivamente para a ampliação dos seus conhecimentos linguísticos e culturais. E todos, sem exceção, manifestaram o interesse em participar de um novo curso sobre a ópera.

Ao final do questionário, os alunos tiveram a oportunidade de comentar livremente o curso. Em geral, verifica-se a repetição dos pontos positivos e negativos anteriormente citados, acrescida de agradecimentos e algumas observações interessantes, como as reportadas abaixo:

Sexo Masculino, 72 anos, professor:

1) O nome do curso foi escolhido com muita felicidade. Nem todos são loucos por ópera, mas muitos se interessam pela língua e pela cultura italiana, e o curso conseguiu preencher esse ponto.

2) A didática foi magnífica, todos os alunos se interessaram, participaram com prazer das aulas e aprenderam bastante.

3) Os alunos aprenderam muito do idioma italiano, talvez mais do que em 12 horas de aula em um nível "n" qualquer.

Sexo feminino, 63 anos, professora:

Foi muito interessante o estudo desta ópera. O exame mais atento e acurado do libreto me fez ver come ele é bem construído. Os personagens já são delineados do início, com poucas palavras.

Sexo feminino, 23 anos, estudante:

(...) Outro problema foi a diversidade dos níveis linguísticos em relação à língua italiana e também a diversidade da idade dos alunos. Essa diversidade linguística e etária tanto pode enriquecer a experiência de aprendizado, como pode oferecer mais dificuldades para a realização do curso.

Sexo feminino, 58 anos, advogada:

Foi uma ótima ideia. Sabia pouco da ópera. Gosto muito da música, especialmente do bel canto.

O curso foi muito bom e nem um pouco entediante. Obrigada. 
O curso contribuiu muito para o meu aprendizado, porque exercitamos as paráfrases e trabalhamos com os adjetivos que, pelo menos para mim, são exercícios importantíssimos e eficientes para ampliar o vocabulário da língua italiana. Tive a oportunidade de relembrar também algumas palavras já esquecidas.

Sexo feminino, 19 anos, estudante:

Em geral, gostei muito do curso porque a professora é muito boa e simpática. Além disso, conhece o tema do qual ele trata. A oportunidade de praticar a língua italiana foi muito boa, porque não é a mesma coisa em um curso de língua, e essa diferença é sentida pelo aluno.

O que poderia mudar, em minha opinião, é a quantidade de alunos, porque, com menos pessoas, poderíamos fazer as atividades todos juntos e mais dinamicamente.

Sexo masculino, 22 anos, estudante:

O curso me trouxe segurança, porque pude ampliar muito os meus conhecimentos linguísticos e culturais. Essa ampliação ajudará futuramente.

Sexo feminino, 30 anos, estudante:

(...) eu acho que o curso poderia ser de dois meses. Vimos as cenas, mas há tantas palavras difíceis de se entender em um primeiro momento, e me parece que seria melhor explicar cada cena como fizemos com "La donna è mobile". (...) Talvez em um segundo momento fosse interessante fazer a paráfrase de todas as canções. (...)

Sexo masculino, 40 anos, professor de química:

Em princípio, fiz o curso porque não gostava de ópera, embora nunca a tivesse visto ou ouvido. Talvez fosse uma forma de preconceito. Então, pensei que, fazendo o curso, poderia entender melhor aquele gênero e, assim, saber se, de fato, eu gostaria ou não. Durante o curso, pude perceber que praticava a conversação da língua de uma maneira natural, já que o tema (Rigoletto) era muito rico e nos dava incentivo para fazer as discussões e, também, as atividades propostas. Gostei muito de trabalhar em dupla. Havia também a oportunidade de melhorar o aspecto da compreensão oral ouvindo a música.

Tive um pouco de dificuldade no curso porque o italiano na ópera é um pouco arcaico e, também, porque não sou da área de ciências humanas, o que dificulda, para mim, fazer a interpretação do texto (linguagem metafórica).

Pude perceber que na ópera os personagens são bem construídos. Posso dizer também que gostei muito de algumas árias.

Finalmente, é possível verificar a valoração positiva dos alunos sobre o curso também fora da sala de aula. Uma das alunas postou, no decorrer das aulas, vários vídeos, informações e comentários sobre a ópera Rigoletto em seu blog pessoal. Além de confirmar seu interesse sobre a ópera em questão, essa atitute demonstra a sua vontade de compartilhá-la com seus 
amigos virtuais. A propósito, ela lhes recomenda: "Garotada, essa ópera foi posteriormente gravada em DVD, com o Pavarotti e outros grandes. Vale a pena assistir!". ${ }^{171}$

${ }^{171}$ PARÔNIMO de opilião. Blog pessoal. Disponível em: $<$ http://paronimodeopiliao.blogspot.com/search/label/italiano>. Acesso em: ago 2009. 


\section{CONCLUSÕES}

A prática da primeira versão do curso sobre a ópera Rigoletto foi muito importante para verificar a eficácia do trabalho com o melodrama em sala de aula, o qual só pode trazer benefícios aos alunos de italiano LE.

Com relação à formação discente, o presente trabalho mostrou ser possível desfazer os preconceitos relativos ao gênero operístico e incutir nos alunos senão a paixão, ao menos o respeito e a consciência sobre a sua importância cultural, social e histórica na sociedade italiana. De fato, a metodologia adotada permitiu que os alunos construíssem, efetivamente, a sua própria ideia sobre a significação dessa arte para si e como representação de uma ideologia artística veementemente buscada nos séculos anteriores.

Da mesma forma, demontrou-se que o trabalho com a ópera lírica em sala de aula representa um esforço no sentido de promover a autoaprendizagem e a autonomia do aluno, visto que os meios utilizados para gerar a compreensão e interpretação do drama consideraram o sincretismo da música, da encenação e do texto escrito instrumentos de controle contra a angústia dos aprendizes de língua estrangeira. Essas linguagens serviram de apoio à compreensão das cenas, ao mesmo tempo em que foram determinantes para complementar e reforçar a análise do texto escrito, sobretudo no que concerne à utilização didática dos traços formais do gênero operístico, como a redundância e a exacerbação dos afetos.

Por isso, a sensação de "sobreviver" e superar as dificuldades da linguagem verbal do melodrama certamente refletirá no confronto com outros textos autênticos, literários ou não, que também se valem de outras linguagens para trasmitir o seu significado pleno.

O percurso didático "da emoção à razão", teorizado e aplicado em cada cena da unidade didática apresentada, buscou simular o percurso gerativo de sentido adotado na análise semiótica do texto. Partimos de uma fase mais simples e abstrata, que apelava para o sentido da música e da encenação, e chegamos à fase mais complexa e concreta da análise do discurso, que apelava para o reconhecimento dos elementos sugeridos nas fases anteriores e para a acuidade dessas informações verbalizadas e figurativizadas no libreto. Nesta última fase, as atividades de compreensão escrita foram elaboradas a partir da paráfrase do libreto, o que possibilitou que se despertasse nos alunos a sua capacidade natural de reformular textos e não se intimidar diante de formas arcaicas ou de uso estritamente literário da língua. 
Portanto, ainda que o texto escrito da ópera esteja demasiado distante da realidade lingüística italiana de hoje, devemos considerar o fato de que as paráfrases de que se incumbiram os alunos nas atividades, assim como todas as discussões em sala de aula sobre os temas da ópera, veicularam a língua italiana moderna, o que possibilitou a eles estar em constante exposição e contato com o uso atual do idioma italiano.

Podemos dizer, enfim, que a ópera lírica foi utilizada como um instrumento moderno de ensino-aprendizagem da língua estrangeira, o qual considera o prazer um elemento necessário para a apreensão do input. O prazer de conhecer e estudar uma ópera lírica no original, participando ativamente da construção do seu sentido, certamente motivou e instigou os alunos a completarem o processo didático. Além disso, as discussões problematizaram temas universais e, portanto, pertencentes à realidade dos alunos, como a fidelidade, o papel da mulher na sociedade, a visão masculina sobre a essência feminina, o amor entre pais e filhos, etc.

Mas não é só isso. O que torna a ópera um instrumento tão especial em relação a tantos outros que poderiam versar as mesmas temáticas é o fato de ela tensionar foricamente cada tema de modo profundo, permitindo que as ações sejam consideradas a partir do estado que acomete o sujeito passional. Assim, é possível que se estabeleça o envolvimento do aluno com o drama e até mesmo a sua identificação com as personagens.

Concluo expressando a minha máxima satisfação em ter chegado até aqui, convicta de que a ópera seja um instrumento didático em potencial a ser explorado nas aulas de italiano LE. Além disso, espero que a didatização da ópera possa abrir caminhos para o trabalho com outros materiais autênticos por meio de uma abordagem semiótica que adote o percurso didático "da emoção à razão", simulando o sentido da própria vida. Afinal, são as emoções que impulsionam às ações, inclusive no que se refere ao ensino-aprendizagem de uma língua estrangeira. 


\section{REFERÊNCIAS}

ADORNO, T. W. Quasi una fantasia. Tradução de J. L. Leleu. Paris, Gallimard, 1982.

ARISTÓTELES, Arte poética. Tradução de Pietro Nassetti, São Paulo: Martin Claret, 2006.

BALBONI, P. Tecniche didattiche per l'educazione lingüística. Italiano, lingue straniere, lingue classiche. 5 ed. Torino: UTET, 2002. 2006a.

Le sfide di Babele. Insegnare le lingue nelle società complesse. 4 ed. Torino: UTET,

Insegnare la letteratura italiana a stranieri. Risorse per docenti di italiano come lingua straniera. Perugia: Guerra, 2006b.

BARBOSA, A. G. A Paráfrase como proposta linguístico pedagógica para uso no ensino de línguas. Tese (Doutorado em Linguística Aplicada) - Universidade Federal de Pernambuco, 2005.

BARROS, D. L. P. Teoria do discurso. Fundamentos semióticos. 3 ed. São Paulo: Humanitas, 2002.

BEIVIDAS, W. Reflexões sobre o conceito de imanência em semiótica Por uma epistemologia discursiva, In CASA - Cadernos de Semiótica Aplicada, Vol. 6, N. 2, 2008. Disponível no site da UNESP: Campus Araraquara, $<<$ http://www.fclar.unesp.br/seer/index.php?journal=casa\&page=search\&op=titles\&searchPage =5 >> Último acesso em 5 dez 2009.

BLUMENSCHEIN, E. C. Paráfrase e compreensão de textos: alguns aspectos. 1997. Dissertação (Mestrado em Semiótica e Linguistica Geral) - Faculdade de Filosofia, Letras e Ciências Humanas, Universidade de São Paulo, 1997.

BRAIT, B.; MELO, R. Enunciado / enunciado concreto / enunciação In: BRAIT, B. (org.) Bakhtin : conceitos-chave, 4 ed. São Paulo: Contexto, 2008. 
CARRESI, S.; CHIARENZA, S.; FROLLANO, E. L'italiano all'opera. Attività linguistiche attraverso 15 arie famose. Roma: Bonacci editore, 1998.

CARVALHO, A. A. Materiais autênticos no ensino de línguas estrangeiras. In. Revista Portuguesa de Educação ISSN 0871-9187. (1993) 6:2 117-124. citado do Resumo. Texto disponível no site da Universidade do Minho: $<$ http://repositorium.sdum.uminho.pt/handle/1822/518> acesso em 15 nov 2008.

CASOY, S. Ópera em São Paulo: 1952-2005. São Paulo: Editora da Universidade de São Paulo, 2006.

CILIBERTI A. Grammatica, pedagogia, discorso, Firenze: La Nuova Italia, 1991.

COELHO, L. M. A ópera barroca italiana. São Paulo: Perspectiva, 2000.

COELHO, L. M. A ópera romântica italiana. São Paulo: Perspectiva, 2002.

COELHO, L. M. A ópera italiana após 1870. São Paulo: Perspectiva, 2002.

COELHO, L. M. A ópera clássica italiana. São Paulo: Perspectiva, 2003.

COLI, J. A paixão segundo a ópera. São Paulo: Perspectiva, 2003.

CONFORTI, C.; CUSIMANO, L. Linea Diretta nuovo 1a. Corso di italiano per principianti. Perugia: Guerra, 2005.

CONFORTI, C.; CUSIMANO, L. Linea Diretta nuovo 1b. Corso di italiano per principianti. Perugia: Guerra, 2005.

CONFORTI, C.; CUSIMANO, L. Linea Diretta 2. Corso di italiano per principianti. Perugia: Guerra, 1997.

CONSIGLIO D'EUROPA. Quadro comune europeo di riferimento per le lingue: Apprendimento, insegnamento, valutazione. 2 ed. Tradução do inglês de Franca Quartapelle e Daniela Bertocchi. Milano: RCS Scuola/Firenze: La Nuova Italia, 2004. 
CRYSTAL, D. The Cambridge encyclopedia of language. 5 ed. Cambrige University Press, 1991.

DE MAURO, T.; VELDOVELLI, M. Italiano 2000: I pubblici e le motivazioni dell'italiano diffuso fra stranieri. Roma: Bulzoni, 2003.

DUCROT, O. O dizer e o dito. Tradução de Eduardo Guimarães. Campinas: Pontes, 1987.

ECO, U. Como se faz uma tese. 11 ed. Tradução de Gilson Cesar Cardoso de Souza. São Paulo: Atlas, 1994.

. Sobre a literatura. Tradução de Eliana Aguiar. Rio de Janeiro: Record, 2003.

FARIA, A. de. A Volubilidade Feminina. Textos Escolhidos. Disponível no Website da Academia Brasileira de Letras:

$<\underline{\text { http:} / / \text { www.academia.org.br/abl/cgi/cgilua.exe/sys/start.htm?infoid }=59 \& \text { sid }=205}>$. Acesso em jun 2009.

FERREIRA, M. Como usar a música na sala de aula. 3 ed. São Paulo: Contexto, 2002.

FIORIN, J. Semiótica das Paixões: o Ressentimento. Editorial. Alfa, São Paulo, v.51, n.1, p.9$22,2007$.

FOnTANille, J; ZILBERBERG, C. Tensão e significação. Tradução de Luiz Tatit e Waldir Beividas. São Paulo : Discurso Editorial: Humanitas, 2001.

FREDDI, G. Glottodidattica : fondamenti, metodi e tecniche, Torino : UTET libreria, 1994.

FRAGA, F.; BLAS, M. A ópera. Tradução de Eduardo Francisco Alves, São Paulo: Angra, 2001.

FRANZONI, P. Nos bastidores da comunicação autêntica. Uma reflexão em lingüística aplicada. Campinas: Editora da Unicamp. 1992.

FUCHS, C. La paraphrase. Paris: Presses Universitaires de France, 1982. 
GIUNCHI P., Grammatica esplicita grammatica implicita, Bologna: Zanichelli, 1990.

GREIMAS. A. J.; COURTÉS, J. Dicionário de semiótica. Vários tradutores. São Paulo: Contexto, 2008.

HALLIDAY, M. A. K.; HASSAN, R. Language, Context and Text: a social semiotic perspective, 2 ed. Oxford: Oxford University Press, 1989.

HOUAISS, A.; VILLAR, M. S. Dicionário Houaiss da Língua Portuguesa. Rio de Janeiro: Objetiva, 2001.

KOBBE, G., O livro completo da ópera. Tradução de Clovis Marques, Rio de Janeiro : Jorge Zahar, 1991.

KRASHEN, S. D. The input hypothesis : Issues and implications. London : Longman, 1989.

LONG M. Focus on form in tasked-based language teaching. In: LAMBERT, R.; SHOHAMY, E. (Org.) Language policy and pedagogy: Essays in honor of A. Ronald Walton. Philadelphia: John Benjamins, pp. 179 - 192, 2000.

MASETTO, M. T. Didática. A aula como centro. 2 ed. São Paulo: FTD, 1997.

MIGLIORINI, B. Storia della lingua italiana. 6 ed. Firenze: Sansoni, 1993.

MAGGINI, M.; MICHELI, P. TENDENZE ITALIANE N.22: catálogo. Perugia: Guerra, 2009. Catálogo disponível no site da editora Guerra: $<<$ http://www.guerraedizioni.com/books/index.cfm?node $=0,1,1020,1257>>$, acessado em 5 abr 2009.

MURESU, G., La parola cantata : studi sul melodramma italiano del Settecento. Roma: Bulzoni, 1982.

OROZ, S. Melodrama : o cinema de lágrimas da América Latina, Rio de Janeiro: Rio Fundo Editora, 1992.

OXFORD, R. L., Language learning strategies : what every teacher should know. Boston: Heinle \& Heinle, 1990. 
PAIVA, V.L.M.O. Estratégias individuais de aprendizagem de língua inglesa. Letras e Letras. v. 14, n. 1, jan./jul. 1998. p. 73-88. Disponível em

$<$ http://www.veramenezes.com/strategies.htm>, último acesso em 5 dez 2009.

PARÔNIMO de opilião. Blog pessoal. Disponível em:

$<$ http://paronimodeopiliao.blogspot.com/search/label/italiano>. Acesso em: ago 2009.

PARRET, H. Enunciação e Pragmática. Tradução de Eni Pulcinelli Orlandi et. al.

Campinas: Unicamp, 1988.

PEIXOTO, F. Ópera e encenação, Rio de Janeiro: Paz e Terra, 1986.

PICHIASSI, M. Fondamenti di glottodidattica : temi e problemi della didattica linguística, Perugia: Edizioni Guerra, 1999.

PONZIO, A. Enunciazione e testo letterario nell'insegnamento dell'italiano come LS. Perugia: Guerra, 2001.

RIGOLETTO. Direção: Jean-Pierre Ponnelle. Maestro: Riccardo Chailly. Intérpretes: Luciano Pavarotti, Ingvar Wixell, Edita Gruberova, Ferruccio Furlanetto, Victoria Vergara, Fedora Barbieri. Unitel GmbH \& Co. KG, Mônaco, 1983.

SAMARITANI, P. L. Rigoletto. [S.1: s.d.], p.1. In: TEATRO Regio di Parma. Website da instituição. Disponível em: <http://www.teatroregioparma.org>. Acesso em: jun de 2009.

SANTOS, A. C. dos; MENEZES, L. de S. C. de. O lugar e a vez da literatura paradidática nas aulas de E/LE. Disponível em: $<$ http://www.filologia.org.br/viiicnlf/anais/caderno0910.html>. Acesso em: 17 nov. 2008.

SANTORO, E. Da indissociabilidade entre o ensino de língua e de literatura: uma proposta para o ensino do italiano como língua estrangeira em cursos de Letras. 2007. Tese (Doutorado em Língua e Literatura Italiana) - Faculdade de Filosofia, Letras e Ciências Humanas, Universidade de São Paulo, 2007.

SAUSSURE, F., Curso de lingüística geral. Tradução de Antônio Chelini, José Paulo Paes e Izidoro Blikstein. São Paulo: Cultrix: EDUSP, 1969. 
SEGRETO, V. R. La genesi di Rigoletto - Un viaggio nell'epistolario verdiano. In: Teatro Regio di Parma. Website da instituição. Disponível em: <http://www.teatroregioparma.org>. Acesso em: jun 2009.

SCHUMANN, J. The Neurobiology of Affect in Language, Oxford: Blackwell, 1997. SUHAMY, J. Guia da Ópera. Tradução de Paulo Neves. Porto Alegre: L\&PM, 1997.

TATIT, L. Musicando a semiótica : ensaios, São Paulo : Annablume, 1998. Análise semiótica através das letras, São Paulo : Ateliê Editorial, 2001.

TERREL, T. D. A Natural Approach to Second Language Acquisition and Learning, Revista The Modern Language Journal, vol. 61. n. 7, pp. 325-337, nov 1997.

TITONE, R. Psicolinguistica aplicada. São Paulo : Summus, 1983.

VERDI, G.; PIAVE, F. M. La Traviata: melodramma in tre atti. Milano : Ricordi, 1954.

. Rigoletto: melodramma in tre atti. Libretto disponível no site Ópera Glass: < http://opera.stanford.edu/Verdi/Rigoletto/libretto.html>, último acesso em 5 dez 2009.

ZIGLIO, L.; RIZZO, G. Espresso 1. Corso di italiano. Libro dello studente ed esercizi. Firenze: Alma edizioni, 2008.

ZIGLIO, L.; RIZZO, G. Espresso 2. Corso di italiano. Libro dello studente ed esercizi. Firenze: Alma edizioni, 2008.

ZIGLIO, L.; RIZZO, G. Espresso 3. Corso di italiano. Libro dello studente ed esercizi. Firenze: Alma edizioni, 2008.

WIKIPÉDIA. Enciclopédia virtual. Disponível em: <http://pt.wikipedia.org/wiki/Teatro>. Acesso em nov 2008. 
ANEXOS 
ANEXO A - Libreto utilizado no curso "Rigoletto: per gli amanti della lingua e della cultura italiana"

Rigoletto

Opera in tre atti

Musica di Giuseppe Verdi

Libretto di Francesco Maria Piave

Il Duca di Mantova Tenore

Rigoletto, buffone di Corte Baritono

Gilda, figlia di Rigoletto Soprano

Sparafucile, bravo Basso

Maddalena, sua sorella Contralto

Giovanna, custode di Gilda

Mezzosoprano

Il Conte di Monterone Baritono

Marullo, cavaliere Baritono

Matteo Borsa, cortigiano Tenore

Il Conte di Ceprano Basso

La Contessa, sua sposa Mezzosoprano

Usciere di Corte Basso

Paggio della Duchessa Mezzosoprano

Cavalieri, Dame, Paggi, Alabardieri.

La scena si finge nella città di Mantova e suoi dintorni. Epoca, il secolo XVI.

\section{Atto Primo}

\section{Scena I}

Sala magnifica nel palazzo ducale, con porte nel fondo che mettono ad altre sale, pure splendidamente illuminate.

Folla di Cavalieri e Dame che passeggiano nelle sale del fondo - Paggi che vanno e vengono - Nelle sale in fondo si vedrà ballare. Da una delle sale vengono parlando fra loro il Duca e Borsa.

DUCA:

Della mia bella incognita borghese

Toccare il fin dell'avventura io voglio.

BORSA:

Di quella giovin che vedete al tempio?

DUCA:

Da tre mesi ogni festa.
BORSA:

La sua dimora?

DUCA:

In un remoto calle;

Misterioso un uom v'entra ogni notte.

BORSA:

E sa colei chi sia l'amante suo?

DUCA:

Lo ignora.

(Un gruppo di dame e cavalieri attraversano la sala)

BORSA:

Quante beltà!... Mirate.

DUCA:

Le vince tutte di Cepran la sposa.

BORSA:

Non v'oda il conte, o Duca...

DUCA:

A me che importa?

BORSA:

Dirlo ad altra ei potria...

DUCA:

Né sventura per me certo saria.

Questa o quella per me pari sono a quant'altre d'intorno, d'intorno mi vedo; del mio core l'impero non cedo meglio ad una che ad altra beltà. La costoro avvenenza è qual dono di che il fato ne infiora la vita; s'oggi questa mi torna gradita, forse un'altra, forse un'altra doman lo sarà, un'altra, forse un'altra doman lo sarà.

La costanza, tiranna del core, 
detestiamo qual morbo, qual morbo crudele;

sol chi vuole si serbe fidele;

non v'ha amor, se non v'è libertà.

De' mariti il geloso furore, degli amanti le smanie derido; anco d'Argo i cent'occhi disfido se mi punge, se mi punge una qualche beltà, se mi punge una qualche beltà.

\section{Atto Primo - Scena II}

Detti, il Conte di Ceprano che segue da lungi la sua sposa servita da altro

Cavaliere. Dame e Signori entrano da varie parti.

DUCA: (alla Contessa di Ceprano movendo ad incontrarla con molta galanteria)

Partite?... crudele!...

CONTESSA DI CEPRANO:

Seguire lo sposo

m'è forza a Ceprano.

DUCA:

Ma dee luminoso

in Corte tal astro qual sole brillare.

Per voi qui ciascuno dovrà palpitare.

Per voi già possente la fiamma d'amore (con enfasi baciandole la mano)

inebria, conquide, distrugge il mio core.

CONTESSA DI CEPRANO:

Calmatevi...

DUCA:

La fiamma d'amore

inebria, conquide, distrugge il mio core.

CONTESSA DI CEPRANO:

Calmatevi, calmatevi...

DUCA:

Per voi già possente la fiamma d'amore inebria, conquide, (dà il braccio alla Contessa ed esce con

lei)

distrugge il mio core.

Atto Primo - Scena III

Detti e Rigoletto, che s'incontra nel signor

di Ceprano; poi Cortigiani

RIGOLETTO: (al Conte Ceprano)

In testa che avete, signor di Ceprano?

(Ceprano fa un gesto d'impazienza e segue il Duca)

RIGOLETTO: (ai Cortigiani)

Ei sbuffa! Vedete?

CORO:

Che festa!

RIGOLETTO:

Oh sì!..

BORSA:

Il Duca qui pur si diverte!...

\section{RIGOLETTO:}

Così non è sempre? Che nuove scoperte! Il giuoco ed il vino, le feste, la danza, battaglie, conviti, ben tutto gli sta. Or della Contessa l'assedio egli avanza, (ridendo)

e intanto il marito fremendo ne va. (esce)

\section{Atto Primo - Scena IV \\ Detti e Marullo}

MARULLO: (entra premuroso)

Gran nuova! Gran nuova!

BORSA:

Che avvenne? parlate!

MARULLO:

Stupir ne dovrete...

BORSA: 
Narrate, narrate...

MARULLO: (ridendo)

Ah, ah!... Rigoletto...

BORSA:

Ebben?

MARULLO:

Caso enorme!...

BORSA:

Perduto ha la gobba? non è più difforme?

MARULLO:

Più strana è la cosa!

(con gravità)

Il pazzo possiede...

BORSA: (con sorpresa)

Infine?

MARULLO:

Un'amante!

BORSA: (con sorpresa)

Un'amante! Chi il crede?

MARULLO:

Il gobbo in Cupido or s'è trasformato...

BORSA:

Quel mostro? Cupido!

BORSA, MARULLO:

Cupido beato!

Atto Primo - Scena V

Detti e il Duca, seguito da Rigoletto, poi da Ceprano

DUCA: (a Rigoletto)

Ah, più di Ceprano importuno non v'è... La cara sua sposa è un angiol per me!

RIGOLETTO:

Rapitela.
DUCA:

È detto; ma il farlo?

RIGOLETTO:

Sta sera.

DUCA:

Non pensi tu al conte?

RIGOLETTO:

Non c'è la prigione?

DUCA:

Ah no.

RIGOLETTO:

Ebben... s'esilia.

DUCA:

Nemmeno, buffone.

RIGOLETTO:

Allora...

(indicando di farla tagliare)

allora la testa...

CONTE DI CEPRANO:

(Oh l'anima nera!)

DUCA: (battendo colla mano una spalla al Conte)

Che dì, questa testa?...

RIGOLETTO:

È ben naturale!

Che far di tal testa? A cosa ella vale?

CONTE DI CEPRANO: (infuriato

brandendo la spada)

Marrano!

DUCA: (a Ceprano)

Fermate!

RIGOLETTO:

Da rider mi fa.

MARULLO:

In furia è montato! 
DUCA: (a Rigoletto)

Buffone, vien qua.

BORSA:

In furia è montato!

MARULLO:

In furia è montato!

CORO:

In furia è montato!

DUCA:

Ah sempre tu spingi

lo scherzo all'estremo.

CONTE DI CEPRANO: (a Cortigiani)

Vendetta del pazzo!

Contr'esso un rancore di noi chi non ha?

RIGOLETTO:

Che coglier mi puote? Di loro non temo.

DUCA:

Quell'ira che sfidi, colpir... ti potrà...

CONTE DI CEPRANO:

Vendetta! In armi chi ha core

BORSA, MARULLO

Ma come?

RIGOLETTO:

Del duca il protetto nessun... toccherà.

CONTE DI CEPRANO:

doman sia da me. A notte.

BORSA, Marullo:

Sì. Sarà.

DUCA:

Ah sempre tu spingi

RIGOLETTO:

Che coglier mi puote? Di loro non temo,

BORSA, Marullo, Conte di Ceprano:
Vendetta del pazzo!

Contr'esso un rancore

DUCA:

Lo scherzo all'estremo,

\section{RIGOLETTO:}

Del duca il protetto nessun toccherà, no, no,

BORSA, Marullo, Conte di Ceprano:

Pei tristi suoi modi di noi chi non ha?

DUCA:

Ah sempre tu spingi lo scherzo all'estremo,

\section{RIGOLETTO:}

Nessun, nessuno, nessun, nessuno

CONTE DI CEPRANO:

Vendetta! vendetta!

BORSA, Marullo

Vendetta! vendetta!

DUCA:

Quell'ira che sfidi, quell'ira che sfidi, colpir ti potrà.

\section{RIGOLETTO:}

nessun, nessuno

del duca il protetto, nessuno toccherà.

CONTE DI CEPRANO:

Vendetta! Sta notte chi ha core sia in armi da me.

BORSA, Marullo:

Vendetta! sì! a notte sarà.

DUCA:

Ah sempre tu spingi

RIGOLETTO:

Che coglier mi puote? Di loro non temo,

BORSA, Marullo, Conte di Ceprano:

Vendetta del pazzo! Contr'esso un rancore 
DUCA:

Lo scherzo all'estremo,

RIGOLETTO:

Del duca il protetto nessun toccherà, no, no,

BORSA, Marullo, Conte di Ceprano:

pei tristi suoi modi di noi chi non ha?

DUCA:

Ah sempre tu spingi lo scherzo all'estremo,

RIGOLETTO:

Nessun, nessuno, nessun, nessuno

CONTE DI CEPRANO:

Vendetta! vendetta!

BORSA, MARULLO

Vendetta! vendetta!

DUCA:

Quell'ira che sfidi, quell'ira che sfidi, colpir ti potrà.

RIGOLETTO:

Nessun, nessuno del duca il protetto, nessuno toccherà.

\section{CONTE DI CEPRANO:}

Vendetta!

sta notte chi ha core sia in armi da me.

BORSA, Marullo:

Vendetta! sì! a notte sarà.

BORSA:

Sì vendetta!

MARULLO:

Sì, vendetta!

CEPRANO:

Sì, vendetta!

(La folla dei danzatori invade la sala)

DUCA, RIGOLETTO:
Tutto è gioja!

BORSA:

Sì vendetta!

MARULLO:

Sì, vendetta!

CEPRANO:

Sì, vendetta!

DUCA, RIGOLETTO:

Tutto è festa!

\section{TUTTI:}

Tutto è gioja, tutto è festa; tutto invitaci a godere!

Oh guardate, non par questa or la reggia del piacere! Oh guardate, non par questa, oh guardate, non par questa or la reggia del piacer!

Oh guardate, non par questa or la reggia del piacer!

\section{Atto Primo - Scena VI}

Detti ed il Conte di Monterone

MONTERONE: (entro la scena) Ch'io gli parli.

DUCA:

No!

MONTERONE: (presentandosi) Il voglio.

BORSA, Rigoletto, Marullo, Ceprano: Monterone!

MONTERONE: (fissando il Duca con nobile orgoglio)

Sì, Monteron... la voce mia qual tuono vi scuoterà dovunque.

RIGOLETTO: (al Duca contraffacendo la voce di Monterone)

Ch'io gli parli. 
(con caricatura)

Voi congiuraste,

voi congiuraste contro noi, signore;

e noi, e noi, clementi in vero,

perdonammo...

Qual vi piglia or delirio, a tutte l'ore

di vostra figlia a reclamar l'onore?

MONTERONE: (guardando Rigoletto con ira sprezzante)

Novello insulto!

(al Duca)

Ah sì, a turbare, ah sì, a turbare sarò

vostr'orgie...

verrò a gridare fino a che vegga restarsi

inulto

di mia famiglia l'atroce insulto;

e se al carnefice pur mi darete.

spettro terribile mi rivedrete,

portante in mano il teschio mio,

vendetta a chiedere,

vendetta a chiedere al mondo, al mondo, a

Dio.

DUCA:

Non più, arrestatelo.

RIGOLETTO:

È matto!

BORSA, Marullo, Ceprano:

Quai detti!

MONTERONE: (al Duca e Rigoletto)

$\mathrm{Ah}$, siate entrambi voi maledetti!

BORSA, Marullo, Ceprano:

$\mathrm{Ah}$ !

MONTERONE:

Slanciare il cane a leon morente è vile, o Duca... e tu, serpente,

(a Rigoletto)

tu che d'un padre ridi al dolore,

sii maledetto!

RIGOLETTO: (da sè colpito)

(Che sento! orrore!)
DUCA, BORSA, MARULLO, CEPRANO:

Oh tu che la festa audace hai turbato, da un genio d'inferno qui fosti guidato;

RIGOLETTO:

(Orrore!)

DUCA, BORSA, MARULLO, CEPRANO:

è vano ogni detto, di qua t'allontana va, trema, o vegliardo, dell'ira sovranna è vano ogni detto, di qua t'allontana va, trema, o vegliardo, dell'ira sovrana tu l'hai provocata, più speme non v'è, un'ora fatale fu questa per te, un'ora fatale fu questa per te, fu questa per te,

(Monterone parte fra due alabardieri, tutti gli altri seguono il Duca in altra stanza).

\section{Atto Primo - Scena VII}

L'estremità più deserta d'una via cieca. A sinistra una casa di discreta apparenza con una piccola corte circondata da muro. Nella corte un grosso ed alto albero ed un sedile di marmo; nel muro una porta che mette alla strada; sopra il muro un terrazzo praticabile, sostenuto da arcate. La porta del primo piano dà sul detto terrazzo. A destra della via è il muro altissimo del giardino, e un fianco del palazzo di Ceprano. È notte.

Rigoletto chiuso nel suo mantello. Sparafucile lo segue, portando sotto il mantello una lunga spada.

\section{RIGOLETTO:}

(Quel vecchio maledivami!)

SPARAFUCILE:

Signor?...

RIGOLETTO:

$\mathrm{Va}$, non ho niente. 
SPARAFUCILE:

Né il chiesi... a Voi presente

Un uom di spada sta.

RIGOLETTO:

Un ladro?

SPARAFUCILE:

Un uorn che libera

Per poco da un rivale,

E voi ne avete...

RIGOLETTO:

Quale?

SPARAFUCILE:

La vostra donna è là.

RIGOLETTO:

(Che sento!)

E quanto spendere

Per un signor dovrei?

SPARAFUCILE:

Prezzo maggior vorrei...

RIGOLETTO:

Com'usasi pagar?

SPARAFUCILE:

Una metà s'anticipa,

Il resto si dà poi...

RIGOLETTO:

(Dimonio!) E come puoi

Tanto securo oprar?

SPARAFUCILE:

Soglio in cittade uccidere.

Oppure nel mio tetto.

L'uomo di sera aspetto

Una stoccata, e muor.

RIGOLETTO:

E come in casa?

SPARAFUCILE:

È facile...
M'aiuta mia sorella...

Per le vie danza,.. è bella...

Chi voglio attira... e allor...

RIGOLETTO:

Comprendo...

SPARAFUCILE:

Senza strepito...

È questo il mio stromento,

(mostra la spada)

Vi serve?

RIGOLETTO:

No... al momento...

SPARAFUCILE:

Peggio per voi...

RIGOLETTO:

Chi sa?...

SPARAFUCILE:

Sparafucil mi nomino...

RIGOLETTO:

Straniero?...

SPARAFUCILE: (Per andarsene)

Borgognone...

RIGOLETTO:

E dove all'occasione?...

SPARAFUCILE:

Qui sempre a sera.

RIGOLETTO:

Va.

(Sparafucile parte).

Atto Primo - Scena VIII

Rigoletto, guardando dietro a Sparafucile

RIGOLETTO: 
Pari siamo!... io la lingua, egli ha il pugnale;

L'uomo son io che ride, ei quel che spegne!...

Quel vecchio maledivami!...

O uomini!... o natura!...

Vil scellerato mi faceste voi...!

Oh rabbia!... esser difforme!... esser

buffone!...

Non dover, non poter altro che ridere!...

Il retaggio d'ogni uom m'è tolto... il

pianto!...

Questo padrone mio,

Giovin, giocondo, sì possente, bello,

Sonnecchiando mi dice:

Fa ch'io rida, buffone...

Forzarmi deggio, e farlo!... Oh,

dannazione!...

Odio a voi, cortigiani schernitori!...

Quanta in mordervi ho gioia!..

Se iniquo son, per cagion vostra è solo...

Ma in altr'uom qui mi cangio!...

Quel vecchio malediami!... tal pensiero

Perché conturba ognor la mente mia!.,.

Mi coglierà sventura?... Ah no, è follia.

(Apre con chiave, ed entra nel cortile.)

\section{Atto Primo - Scena IX}

Detto e Gilda ch'esce dalla casa e si getta nelle sue braccia.

RIGOLETTO:

Figlia...

GILDA:

Mio padre!

RIGOLETTO:

A te dappresso

Trova sol gioia il core oppresso.

GILDA:

Oh quanto amore!

RIGOLETTO:

Mia vita sei!

Senza te in terra qual bene avrei?
(Sospira)

GILDA:

Voi sospirate!... che v'ange tanto?

Lo dite a questa povera figlia...

Se v'ha mistero... per lei sia franto...

Ch'ella conosca la sua famiglia.

RIGOLETTO:

Tu non ne hai...

GILDA:

Qual nome avete?

RIGOLETTO:

A te che importa?

GILDA:

Se non volete

Di voi parlarmi...

RIGOLETTO: (interrompendola)

Non uscir mai

GILDA:

Non vo' che al tempio.

RIGOLETTO:

Or ben tu fai.

GILDA:

Se non di voi, almen chi sia

Fate ch'io sappia la madre mia.

RIGOLETTO:

Deh non parlare al misero

Del suo perduto bene...

Ella sentia, quell'angelo,

Pietà delle mie pene...

Solo, difforme, povero,

Per compassion mi amò,

Moria... le zolle coprano

Lievi quel capo amato...

Sola or tu resti al misero...

O Dio, sii ringraziato!...

(Singhiozzando)

GILDA:

Quanto dolor!... che spremere 
Sì amaro pianto può?

Padre, non più, calmatevi...

Mi lacera tal vista...

Atto Primo - Scena X

Il nome vostro ditemi,

Detti e Giovanna dalla casa.

Il duol che sì v'attrista...

RIGOLETTO:

A che nomarmi?... è inutile!...

Padre ti sono, e basti...

Me forse al mondo temono,

D'alcuno ho forse gli asti...

Altri mi maledicono...

GILDA:

Patria, parenti, amici

Voi dunque non avete?

RIGOLETTO:

Patria!... parenti!... dici?...

Culto, famiglia, patria,

(con effusione)

Il mio universo è in te!

GILDA:

Ah se può lieto rendervi,

Gioia è la vita a me!

Già da tre lune son qui venuta,

Né la cittade ho ancor veduta;

Se il concedete, farlo or potrei...

RIGOLETTO:

Mai?... mai!... uscita, dimmi unqua sei?

GILDA:

No.

RIGOLETTO:

Guai!

GILDA:

(Che dissi!)

RIGOLETTO:

GIOVANNA:

Signor!

RIGOLETTO:

Venendo, mi vede alcuno?

Bada, di' il vero...

GIOVANNA:

Ah no, nessuno.

RIGOLETTO:

Sta ben... la porta che dà al bastione

È sempre chiusa?

GIOVANNA:

Lo fu e sarà.

RIGOLETTO:

Veglia, o donna, questo fiore

(a Giovanna)

Che a te puro confidai

Veglia attenta, e non sia mai

Che s'offuschi il suo candor.

Tu dei venti dal furore

Ch 'altri fiori hanno piegato

Lo difendi, e immacolato

Lo ridona al genitor

GILDA:

Quanto affetto!... quali cure!

Che temete, padre mio?

Lassù in cielo, presso Dio

Veglia un angiol protettor.

Da noi stoglie le sventure

Di mia madre il priego Santo;

Non fia mai divelto o infranto

Questo a voi diletto fior.

Ben te ne guarda!

(Potrien seguirla, rapirla ancora!

Qui d'un buffone si disonora

La figlia, e ridesi... Orror!) Olà?

(Verso la casa)

Atto Primo - Scena XI

Detti ed il Duca in costume borghese dalla strada. 
RIGOLETTO:

Alcuno è fuori...

(Apre la porta della corte e, mentre esce a guardar sulla strada, il Duca guizza furtivo nella corte e si nasconde dietro l'albero, gettandoa Giovanna una borsa la fa tacere)

GILDA:

Cielo!

Sempre novel sospetto...

RIGOLETTO: (a Gilda tornando)

Alla chiesa vi seguiva mai nessuno?

GIOVANNA:

Mai.

DUCA:

(Rigoletto!)

RIGOLETTO:

Se talor qui picchiano

Guardatevi da aprir...

GIOVANNA:

Nemmeno al duca...

RIGOLETTO:

Meno che a tutti a lui...

Mia figlia addio.

DUCA:

(Sua figlia!)

GILDA:

Addio, mio Padre.

(S'abbracciano e Rigolettoparte chiudendosi dietro la porta)

\section{Atto Primo - Scena XII}

Gilda, Giovanna, il Duca nella corte, poi Ceprano e Borsa a tempo sulla via.

GILDA:
Giovanna, ho dei rimorsi...

GIOVANNA

E perché mai?

GILDA:

Tacqui che un giovin ne seguiva al tempio.

GIOVANNA:

Perché ciò dirgli?... l'odiate dunque

Cotesto giovin, voi?

GILDA:

No, no, ché troppo è bello e spira amore...

\section{GIOVANNA:}

E magnanimo sembra e gran signore.

GILDA:

Signor né principe - io lo vorrei;

Sento che povero - più l'amerei.

Sognando o vigile - sempre lo chiamo.

E l'alma in estasi - gli dice t'a...

DUCA:

(esce improvviso, fa cenno a Giovanna d'andarsene, e inginocchiandosi a' piedi di Gilda termina la frase):

T'amo!

T'amo ripetilo - sì caro accento, Un puro schiudimi - ciel di contento!

GILDA:

Giovanna?... Ahi misera! -non v'è più alcuno

Che qui rispondami!... - Oh Dio!... nessuno!...

DUCA:

Son io coll'anima - che ti rispondo... Ah due che s'amano - son tutto un mondo!...

GILDA:

Chi mai, chi giungere - vi fece a me?

DUCA:

S'angelo o demone - che importa a te? 
Io t'amo...

GILDA:

Uscitene.

DUCA:

Uscire!... adesso!...

Ora che accendene - un fuoco istesso!...

Ah inseparabile - d'amore il dio

Stringeva, o vergine, - tuo fato al mio! -

È il sol dell'anima, - la vita è amore,

Sua voce è il palpito - del nostro core...

E fama e gloria, - potenza e trono.

Terrene, fragili - cose qui sono.

Una pur avvene - sola, divina,

È amor che agli angeli - più ne avvicina!

Adunque amiamoci, - donna celeste,

D'invidia agli uomini - sarò per te.

GILDA:

(Ah de' miei vergini - sogni son queste

Le voci tenere - sì care a me!)

DUCA:

Che m'ami, deh ripetimi...

GILDA:

L'udiste.

DUCA:

Oh me felice!

GILDA:

Il nome vostro ditemi...

Saperlo non mi lice?

CEPRANO:

Il loco è qui...

(A Borsa dalla via)

DUCA (pensando):

Mi nomino...

BORSA:

Sta ben...

(A Ceprano e partono)

DUCA:

Gualtier Maldè...
Studente sono... povero...

GIOVANNA: (tornando spaventata)

Romor di passi è fuore...

GILDA:

Forse mio padre...

DUCA:

(Ah cogliere

Potessi il traditore

Che sì mi sturba!)

GILDA: (a Giovanna)

Adducilo

Di qua al bastione... ite...

DUCA:

Di' m'amerai tu?...

GILDA:

E voi?

DUCA:

L'intera vita... poi...

GILDA:

Non più... non più... partite...

A2:

Addio... speranza ed anima

Sol tu sarai per me.

Addio... vivrà immutabile

L'affetto mio per te.

(Il Duca entra in casa scortato da

Giovanna. Gilda resta fissando la porta ond'è partito)

\section{Atto Primo - Scena XIII \\ Gilda}

GILDA:

Gualtier Maldè!... nome di lui sì amato, Scolpisciti nel core innamorato!

Caro nome che il mio cor

Festi primo palpitar, 
Le delizie dell'amor

Mi dêi sempre rammentar!

Col pensiero il mio desir

A te ognora volerà,

E pur l'ultimo sospir,

Caro nome, tuo sarà.

(Entra in casa e compariscce sul terrazzo

con una lucerna per vedere ancora una

volta il creduto Gualtiero, che si suppone

partito dall'altra parte)

\section{Atto Primo - Scena XIV}

Marullo, Ceprano, Borsa, Cortigiani

armati e mascherati dalla via. Gilda sul

terrazzo che tosto rientra.

BORSA (indicando Gilda al Coro):

È là.

CEPRANO:

Miratela...

CORO:

Oh quanto è bella!

MARULLO:

Par fata od angiol.

CORO:

L'amante è quella

Di Rigoletto!

\section{Atto Primo - Scena XV}

Detti e Rigoletto concentrato.

RIGOLETTO:

(Riedo!... perché?)

BORSA:

Silenzio... all'opra... badate a me.

RIGOLETTO:

(Ah da quel vecchio fui maledetto!)

(Urta in Borsa)
Chi è là?

BORSA:(ai compagni)

Tacete... c'è Rigoletto.

CEPRANO:

Vittoria doppia!... l'uccideremo...

BORSA:

No, ché domani più rideremo...

MARULLO:

Or tutto aggiusto...

RIGOLETTO:

(Chi parla qua?)

MARULLO:

Ehi Rigoletto?... Di'?

RIGOLETTO: (con voce terribile)

(Chi va là)

MARULLO:

Eh non mangiarci!... Son...

RIGOLETTO:

Chi?

MARULLO:

Marullo.

RIGOLETTO:

In tanto bujo lo sguardo è nullo.

MARULLO:

Qui ne condusse ridevol cosa...

Torre a Ceprano vogliam la sposa.

RIGOLETTO:

(Ohimè respiro!...)

Ma come entrare?

MARULLO: (piano a Ceprano)

La vostra chiave?

(A Rigoletto)

Non dubitare

Non dee mancarci lo stratagemma..

(Gli dà la chiave avuta da Ceprano) 
Ecco le chiavi...

RIGOLETTO:

Sento il tuo stemma.

(Palpandole)

(Ah terror vano fu dunque il mio!)

(Respirando)

N'è là il palazzo... con voi son 'io.

MARULLO:

Siam mascherati...

RIGOLETTO:

Ch'io pur mi mascheri

A me una larva?

\section{MARULLO:}

Sì, pronta è già.

Terrai la scala...

(Gli mette una maschera, e nello stesso

tempo lo benda con un fazzoletto, e lo pone

a reggere una scala, che avranno

appostata al terrazzo)

RIGOLETTO:

Fitta è la tenebra...

MARULLO: (ai compagni)

La benda cieco e sordo il fa.

TUTTI:

Zitti, zitti moviamo a vendetta,

Ne sia colto or che meno l'aspetta.

Derisore sì audace costante

A sua volta schernito sarà!...

Cheti, cheti, rubiamgli l'amante,

$\mathrm{E}$ la corte doman riderà.

(Alcuni salgono al terrazzo, rompon la porta del primo piano, scendono, aprono ad altri ch'entrano dalla strada, e riescono, trascinando Gilda, la quale avrà la bocca chiusa da un fazzoletto. Nel traversare la scena, ella perde una sciarpa)

GILDA (da lontano):

Soccorso, padre mio...
CORO:

Vittoria!...

GILDA: (Più lontano)

Aita!

\section{RIGOLETTO:}

Non han finito ancor!...

qual derisione!...

(Si tocca gli occhi)

Sono bendato!...

(Si strappa impetuosamente la benda e la maschera, ed al chiarore d'una lanterna scordata riconisce la sciarpa, vede la porta aperta, entra, ne trae Giovanna spaventata: la fissa con istupore, si strappa i capelli senza poter gridare; finalmente, dopo molti sforzi esclama: Ah!... la maledizione!!

(sviene)

\section{Atto Secondo}

\section{Scena I}

Salotto nel palazzo ducale. Vi sono due porte laterali, una maggiore nel fondo che si chiude. Al suoi lati pendono i ritratti, in tutta figura, a sinistra del Duca, a destra della sua sposa. V'ha un seggiolone presso una tavola coperta di velluto e altri mobili

(Entra il Duca agitatissimo)

DUCA:

Ella mi fu rapita!

E quando, o ciel... ne'brevi istanti, prima che il mio presagio interno sull'orma corsa ancora mi spingesse! Schiuso era l'uscio!... e la magion deserta! E dove ora sarà quell'angiol caro?... colei che prima potè in questo core destar la fiamma di costanti affetti?... colei sì pura, al cui modesto sguardo quasi spinto a virtù talor mi credo!... Ella mi fu rapita!

E chi l'ardiva?... Ma ne avrò vendetta lo chiede il pianto della mia diletta. Parmi veder le lagrime 
scorrenti da quel ciglio, quando fra il dubbio e l'ansia del subito periglio, dell'amor nostro memore, Il suo Gualtier chiamò. Ned ei potea soccorrerti, cara fanciulla amata, ei che vorria coll'anima farti quaggiù beata; ei che le sfere agli angeli, per te non invidiò.

(entrano frettolosi i cortigiani)

\section{Atto Secondo - Scena II \\ Marullo, Ceprano, Borsa ed altri \\ Cortigiani}

BORSA, MARULLO, CEPRANO:

Duca, duca?

DUCA:

Ebben?

BORSA, MARULLO, CEPRANO: L'amante fu rapita a Rigoletto.

DUCA:

Come? e donde?

BORSA, MARULLO, CEPRANO:

Dal suo tetto.

DUCA:

Ah, ah! dite, come fu?

(siede)

BORSA, MARULLO, CEPRANO:

Scorrendo uniti remota via, brev'ora dopo caduto il dì, come previsto ben s'era in pria, rara beltà ci si scoprì.

Era l'amante di Rigoletto, che, vista appena, si dileguò. Già di rapirla s'avea il progetto, quando il buffone vêr noi spuntò; che di Ceprano noi la contessa rapir volessimo, stolto credé; la scala, quindi, all'uopo messa, bendato, ei stesso ferma tenè.

Salimmo, e rapidi la giovinetta a noi riusciva quindi asportar. Quand'ei s'accorse della vendetta restò scornato ad imprecar, ad imprecar.

DUCA: (da sè)

(Cielo! è dessa!..la mia diletta!)

(al coro)

Ma dove or trovasi la poveretta?

BORSA, MARULLO, CEPRANO:

Fu da noi stessi addotta or qui.

DUCA: (da sè)

(Ah, tutto il ciel non mi rapì!)

(da sè, alzandosi con gioia)

(Possente amor mi chiama, volar io deggio a lei;

il serto mio darei per consolar quel cor. Ah! sappia alfin chi l'ama, conosca alfin chi sono, apprenda ch'anco in trono ha degli schiavi Amor) (Esce frettoloso dal mezzo)

BORSA, MARULLO, CEPRANO:

Oh qual pensier or l'agita, come cangiò d'umor!)

\section{Atto Secondo - Scena III}

Marullo, Ceprano, Borsa, altri Cortigiani, poi Rigoletto

MARULLO:

Povero Rigoletto!

RIGOLETTO: (entro la scena)

La rà, la rà, la la, la rà, la rà, la rà, la rà la rà, la la, la rà, la rà.

TUTTI:

Ei vien! Silenzio.

(Rigoletto entra la scena affettando indifferenza) 
BORSA, MARULLO, CEPRANO:

Oh buon giorno, Rigoletto...

RIGOLETTO:

(Han tutti fatto il colpo!)

CEPRANO:

Ch'hai di nuovo, buffon?..

RIGOLETTO: (contraffacendo Ceprano)

Ch'hai di nuovo, buffon?..

Che dell'usato più nojoso voi siete.

BORSA, MARULLO, CEPRANO:

(ridendo)

Ah! ah! ah!

RIGOLETTO: (aggirandosi per la scena) La rà, la rà, la la la rà, la rà, la rà, la rà. (spiando inquieto dovunque)

(Ove l'avran nascosta?)

BORSA, MARULLO, CEPRANO:

Guardate com'è inquieto!

RIGOLETTO:

La rà, la rà, la rà, la rà, la rà, la rà, la rà, la rà, la rà, la rà, la rà.

BORSA, MARULLO, CEPRANO:

Sì! sì! guardate com'è inquieto!

RIGOLETTO: (a Marullo)

Son felice

che nulla a voi nuocesse

l'aria di questa notte.

MARULLO:

Questa notte!..

RIGOLETTO:

Sì... Oh fu il bel colpo!..

MARULLO:

S'ho dormito sempre!

RIGOLETTO:

Ah, voi dormiste!.. Avrò dunque sognato!..
(S'allontana cantarellando, e visto un fazzoletto lo afferra)

La rà, la rà, la la, la rà, la rà, la rà, la la.

BORSA, MARULLO, CEPRANO:

(Ve', come tutto osserva!)

RIGOLETTO: (gettando il fazzoletto)

Non è il suo. Dorme il Duca tuttor?

BORSA, MARULLO, CEPRANO:

Sì, dorme ancora.

\section{Atto Secondo - Scena IV \\ Detti e un Paggio della Duchessa}

\section{PAGGIO:}

Al suo sposo parlar vuol la Duchessa.

CEPRANO:

Dorme.

\section{PAGGIO:}

Qui or or con voi non era?..

BORSA:

È a caccia...

PAGGIO:

Senza paggi!.. senz'armi!..

BORSA, MARULLO, CEPRANO:

E non capisci

che per ora vedere non può alcuno?..

\section{RIGOLETTO:}

(che a parte è stato attentissimo al dialogo, balzando improvviso tra loro prorompe) Ah! ella è qui dunque!.. Ella è col Duca!..

BORSA, MARULLO, CEPRANO:

Chi?

\section{RIGOLETTO:}

La giovin che sta notte al mio tetto rapiste... 
Ma la saprò riprender... Ella è la...

BORSA, MARULLO, CEPRANO:

Se l'amante perdesti, la ricerca altrove.

RIGOLETTO:

Io vo' mia figlia...

BORSA, MARULLO, CEPRANO:

La sua figlia!..

RIGOLETTO:

Sì... la mia figlia... D'una tal vittoria...

che?.. adesso non ridete?..

(corre verso la porta, ma i cortigiani gli

attraversano il passaggio)

Ella è la!.. la vogl'io... la rendete.

Cortigiani, vil razza dannata,

per qual prezzo vendeste il mio bene?

A voi nulla per l'oro sconviene!.. ma mia figlia è impagabil tesor.

La rendete... o se pur disarmata, questa man per voi fora cruenta; nulla in terra più l'uomo paventa, se dei figli difende l'onor.

(si getta ancora sulla porta che gli è nuovamente contesa)

Quella porta, assassini, assassini, m'aprite, la porta, la porta, assassini, m'aprite.

(lotta alquanto coi cortigiani, poi torna spossato sul davanti della scena)

Ah! voi tutti a me contro venite!..

(piange)

tutti contra me!.. Ah!..

Ebben, piango... Marullo... signore,

tu ch'hai l'alma gentil come il core,

dimmi tu dove l'hanno nascosta?..

È là? non è vero? ... tu taci!.. ohimè!

(piange)

Miei signori.. perdono, pietate...

al vegliardo la figlia ridate...

ridonarla a voi nulla ora costa,

tutto al mondo è tal figlia per me.

Atto Secondo - Scena V

Detti e Gilda ch'esce dalla stanza a sinistra e si getta nelle braccia del padre
GILDA:

Mio padre!

RIGOLETTO:

Dio! mia Gilda!..

Signori... in essa... è tutta la mia famiglia...

Non temer più nulla, angelo mio...

(ai Cortigiani)

fu scherzo!.. non è vero? Io che pur piansi orrido...

(a Gilda)

E tu a che piangi?..

GILDA:

Ah l'onta, padre mio...

RIGOLETTO:

Cielo! Che dici?

GILDA:

Arrosir voglio innanzi a voi soltanto...

RIGOLETTO: (rivolto al Cortigiani con imperioso modo)

Ite di qua, voi tutti...

Se il duca vostro d'appressarsi osasse, ch'ei non entri, gli dite, e ch'io ci sono.

(si abbandona sul seggiolone)

BORSA, MARULLO, CEPRANO: (tra loro)

Coi fanciulli e co'dementi

spesso giova il simular.

Partiam pur, ma quel ch'ei tenti

non lasciamo d'osservar.

(partono)

\section{Atto Secondo - Scena VI \\ Rigoletto e Gilda}

RIGOLETTO:

Parla... siam soli...

GILDA:

(Ciel dammi coraggio!)

Tutte le feste al tempio 
mentre pregava Iddio,

bella e fatale un giovine

offriasi al guardo mio...

se i labbri nostri tacquero,

dagl'occhi il cor, il cor parlò.

Furtivo fra le tenebre

sol ieri a me giungeva...

Sono studente, povero, commosso mi diceva,

e con ardente palpito

amor mi protestò.

Partì... il mio core aprivasi

a speme più gradita,

quando improvvisi apparvero

color che m'han rapita,

e a forza qui m'addussero

nell'ansia più crudel.

RIGOLETTO:

$\mathrm{Ah}$ !

(da sè)

(Solo per me l'infamia

a te chiedeva, o Dio...

ch'ella potesse ascendere

quanto caduto er'io...

Ah presso del patibolo

bisogna ben l'altare!..

ma tutto ora scompare...

l'altare... si rovesciò!)

(a Gilda)

Piangi! piangi fanciulla, fanciulla piangi...

scorrer, scorrer fa il pianto sul mio cor.

GILDA:

Padre, in voi parla un angel

per me consolator.

RIGOLETTO:

Compiuto pur quanto a fare mi resta...

lasciare potremo quest'aura funesta.

GILDA:

Sì

RIGOLETTO: (da sè)

(E tutto un sol giorno cangiare potè)

Atto Secondo - Scena VII
Detti, un usciere e il Conte di Monterone

che attraversa la scena fra gli alabardieri

Usciere: (alle guardie)

Schiudete... ire al carcere Monteron dee.

MONTERONE: (fermandosi verso il ritratto del Duca)

Poichè fosti invano da me maledetto, nè un fulmine o un ferro colpiva il tuo petto,

felice pur anco, o duca, vivrai!...

(esce fra le guardie dal mezzo)

RIGOLETTO:

No, vecchio t'inganni... un vindice avrai!

\section{Atto Secondo - Scena VIII \\ Rigoletto e Gilda}

RIGOLETTO: (con impeto volto al ritratto)

Sì, vendetta, tremenda vendetta di quest'anima è solo desio...

di punirti già l'ora saffretta, che fatale per te tuonerà.

Come fulmin scagliato da Dio, te colpire il buffone saprà.

GILDA:

O mio padre, qual gioja feroce balenarvi ne gl'occhi vegg'io!.. Perdonate, a noi pure una voce di perdono dal cielo verrà, (Mi tradiva, pur l'amo, gran Dio! per l'ingrato ti chiedo pietà!)

(escono dal mezzo)

\section{Atto Terzo}

\section{Scena I}

Deserta sponda del Mincio. A sinistra è una casa a due piani, mezzo diroccata, la cui fronte, volta allo spettatore, lascia 
vedere per una grande arcata l'interno d'una rustica osteria al pian terreno, ed una rozza scala che mette al granaio, entro cui, da un balcone senza imposte, si vede un lettuccio. Nella facciata che guarda la strada è una porta che s'apre per dietro; il muro poi è sì pieno di fessure che dal di fuori si può facilmente scorgere quanto avviene nell'interno. Il resto del teatro rappresenta la destra parte del Mincio, che nel fondo scorre dietro un parapetto in mezza ruina; al di là del fiume è Mantova. È notte.

Gilda e Rigoletto, inquieto, sono sulla strada. Sparafucile nell'interno dell'osteria, seduto sopra una tavola, sta ripulendo il suo cinturone senza nulla intendere di quanto accade al di fuori.

\section{RIGOLETTO:}

E l'ami?

GILDA:

Sempre.

RIGOLETTO:

Pure

tempo a guarirne t'ho lasciato.

GILDA:

Io l'amo.

RIGOLETTO:

Povero cor di donna!.. Ah il vile infame!.. Ma ne avrai vendetta, o Gilda...

GILDA:

Pietà, mio padre...

RIGOLETTO:

E se tu certa fossi

ch'ei ti tradisse, l'ameresti ancora?

GILDA:

Nol so... ma pur m'adora.

RIGOLETTO:

Egli!
GILDA:

Sì.

RIGOLETTO: (la conduce presso una delle fessure del muro, ed ella vi guarda) Ebben, osserva dunque.

GILDA:

Un uomo vedo.

RIGOLETTO:

Per poco attendi.

\section{Atto Terzo - Scena II}

Detti e il Duca, che, in assisa di semplice ufficiale di cavalleria, entra nella sala terrena per una porta a sinistra.

GILDA: (trasalendo)

Ah padre mio!

DUCA: (a Sparafucile)

Due cose, e tosto...

SPARAFUCILE:

Quali?

DUCA:

Una stanza e del vino...

RIGOLETTO:

Son questi i suoi costumi!

SPARAFUCILE:

Oh il bel zerbino!

(entra nell'interno)

DUCA:

La donna è mobile qual piuma al vento, muta d'accento e di pensiero.

Sempre un amabile leggiadro viso, in pianto o in riso, è menzognero.

È sempre misero chi a lei s'affida, chi le confida mal cauto il core! 
Pur mai non sentesi

felice appieno

chi su quel seno non liba amore!

(Sparafucile rientra con una bottiglia di vino e due bicchieri che depone sulla tavola, quindi batte col pomo della sua lunga spada due colpi al soffitto. A quel segnale una ridente giovane, in costume di zingara, scende a salti la scala. Il Duca corre per abbracciarla, ma ella gli sfugge.

Frattanto Sparafucile, uscito sulla via, dice a parte a Rigoletto)

\section{SPARAFUCILE:}

È là il vostr'uomo... viver dee o morire?

RIGOLETTO:

Più tardi tornerò l'opra a compire.

(Sparafucile si allontana dietro la casa lungo il fiume)

\section{Atto Terzo - Scena III}

Gilda e Rigoletto sulla via, il Duca e

Maddalena nel piano terreno

DUCA:

Un dì, si ben rammentomi, o bella, t'incontrai...

mi piacque di te chiedere, e intesi che qui stai.

Or sappi, che d'allora

sol te quest'alma adora.

GILDA:

Iniquo!...

MADDALENA:

Ah, ah!... e vent'altre appresso

le scorda forse a desso?

Ha un'aria il signorino da vero libertino...

DUCA: (per abbracciarla)

Sì... un mostro son...

GILDA:
Ah padre mio!...

MADDALENA:

Lasciatemi, stordito.

DUCA:

Ih, che fracasso!

MADDALENA:

Stia saggio.

DUCA:

E tu sii docile, non farmi tanto chiasso.

Ogni saggezza chiudesi nel gaudio e nell'amore...

(le prende la mano)

La bella mano candida!...

MADDALENA:

Scherzate voi, signore.

DUCA:

No, no.

MADDALENA:

Son brutta.

DUCA:

Abbracciami.

GILDA:

Iniquo!

MADDALENA:

Ebro!...

DUCA: (ridendo)

D'amor ardente.

MADDALENA:

Signor l'indifferente, vi piace canzonar?

DUCA:

No, no, ti vo'sposar.

MADDALENA:

Ne voglio la parola... 
DUCA:

Amabile figliuola!

RIGOLETTO: (a Gilda che avrà tutto osservato ed inteso)

E non ti basta ancor?

GILDA:

Iniquo traditor!

DUCA:

Bella figlia dell'amore, schiavo son de'vezzi tuoi; con un detto sol tu puoi le mie pene consolar. Vieni e senti del mio core il frequente palpitar. Con un detto sol tu puoi le mie pene consolar.

\section{MADDALENA:}

Ah! ah! rido ben di core, chè tai baje costan poco, quanto valga il vostro gioco, mel credete so apprezzar. Sono avvezza, bel signore Ad un simile scherzar.

GILDA:

Ah così parlar d'amore a me pur l'infame ho udito! Infelice cor tradito, per angoscia non scoppiar, Perché o credulo mio core, un tal uomo dovevi amar!

RIGOLETTO: (a Gilda) Taci, il piangere non vale; Ch'ei mentiva or sei sicura... Taci, e mia sarà la cura la vendetta d'affrettar. Pronta fia sarà fatale, io saprollo fulminar.

RIGOLETTO:

M'odi!... ritorna a casa... oro prendi, un destriero, una veste viril che t'apprestai, e per Verona parti...

Sarovvi io pur doman...

GILDA:

Or venite...

RIGOLETTO:

Impossibil.

GILDA:

Tremo.

RIGOLETTO:

$\mathrm{Va}$ !

(Il Duca e Maddalena stanno fra loro parlando, ridendo e bevendo. Rigoletto va dietro la casa, e ritorna con Sparafucile, contandogli delle monete)

\section{Atto Terzo - Scena IV}

Sparafucile, Rigoletto, il Duca e Maddalena

\section{RIGOLETTO:}

Venti scudi hai tu detto?... Eccone dieci; e dopo l'opra il resto.

Ei qui rimane?

SPARAFUCILE:

Sì.

RIGOLETTO:

Alla mezzanotte ritornerò.

\section{SPARAFUCILE:}

Non cale.

A gettarlo nel fiume basto io solo.

RIGOLETTO:

No, no, il vo' far io stesso.

SPARAFUCILE:

Sia!... Il suo nome?

RIGOLETTO:

Vuoi saper anche il mio? 
Egli è Delitto, Punizion son io.

(Parte. Entro le scene si vedrà un lampo)

Atto Terzo - Scena V

Detti meno Rigoletto

SPARAFUCILE:

La tempesta è vicina!...

più scura fia la notte.

DUCA: (per prenderla)

Maddalena...

MADDALENA: (sfuggendogli)

Aspettate... mio fratello

viene...

DUCA:

Che importa?

MADDALENA:

Tuona!

SPARAFUCILE: (entrando in casa)

E pioverà fra poco.

DUCA:

Tanto meglio!

(a Sparafucile)

Tu dormerai in scuderia...

all'inferno... ove vorrai.

SPARAFUCILE:

Oh, grazie.

MADDALENA: (piano al Duca)

Ah, no, partite.

DUCA: (a Maddalena)

Con tal tempo?

SPARAFUCILE: (piano a Maddalena)

Son venti scudi d'oro.

(al Duca)

Ben felice d'offrirvi la mia stanza...

se a voi piace tosto a vederla andiamo.

(prende un lume e s'avvia per la scala)

DUCA:
Ebben! sono con te... presto... vediamo.

(dice una parola all'orecchio di

Maddalena e segue Sparafucile)

MADDALENA:

Povero giovin!.. grazioso tanto!

Dio, qual notte è questa!

DUCA: (sul granaio)

Si dorme all'aria aperta? bene, bene!..

Buona notte.

SPARAFUCILE:

Signor, vi guardi Iddio.

(il Duca depone la spada e il cappello)

DUCA:

Breve sonno dormiam...

stanco son io.

(Depone il cappello, la spada e si stende sul letto, dove in breve addormentasi.

maddalena frattanto siede presso la tavola, Sparafucile beve della bottiglia lasciata dal Duca. Rimangono ambidue taciturni per qualche istante, e preoccupati da gravi pensieri)

MADDALENA:

È amabile in vero cotal giovinotto!

SPARAFUCILE:

Oh sì, venti scudi ne dà di prodotto.

MADDALENA:

Sol venti?.. son pochi!.. valeva di più.

SPARAFUCILE:

La spada, s'ei dorme, va... portami giù.

MADDALENA: (Sale al granaio e contemplando il dormente)

Peccato è pur bello!

(Ripara alla meglio il balcone e scende).

Atto Terzo - Scena VI 
Detti e Gilda, che comparisce nel fondo della via in costume virile, con stivali e speroni, e lentamente si avanza verso l'osteria, mentre Sparafucile continua a bere. Spessi lampi e tuoni.

GILDA:

Ah, più non ragiono!..

Amor mi trascina!.. mio padre, perdono... Qual notte d'orrore!.. Gran Dio, che accadrà!

MADDALENA: (sarà discesa ed avrà posata la spada del Duca sulla tavola) Fratello?..

GILDA:

Chi parla?..

(osserva per la fessura)

SPARAFUCILE:

Al diavol ten va...

MADDALENA:

Somiglia un Apollo quel giovine... io l'amo...

ei m'ama...riposi... nè più l'uccidiamo.

GILDA: (ascoltando)

Oh cielo!

SPARAFUCILE: (gettandole un sacco) Rattoppa quel sacco...

MADDALENA:

Perchè?

SPARAFUCILE:

Entr'esso il tuo Apollo, sgozzato da me, gettar dovrò al fiume...

GILDA:

L'inferno qui vedo!

MADDALENA:

Eppure il danaro salvarti scommetto, serbandolo in vita.

SPARAFUCILE:
Difficile il credo.

MADDALENA:

M'ascolta... anzi facil ti svelo un progetto.

De'scudi già dieci dal gobbo ne avesti; venire cogl'altri più tardi il vedrai...

Uccidilo e, venti allora ne avrai,

Così tutto il prezzo goder si potrà.

GILDA:

Che sento! mio padre!

SPARAFUCILE:

Uccider quel gobbo!... che diavol dicesti! Un ladro son forse?... Son forse un bandito?...

Qual altro cliente da me fu tradito?...

Mi paga quest'uomo... fedele m'avrà

MADDALENA:

Ah, grazia per esso.

SPARAFUCILE:

È duopo ch'ei muoja...

MADDALENA: (va per salire)

Fuggire il fo adesso.

GILDA:

Oh buona figliuola!

SPARAFUCILE: (trattenedola)

Gli scudi perdiamo.

MADDALENA:

È ver!...

SPARAFUCILE:

Lascia fare...

MADDALENA:

Salvarlo dobbiamo.

SPARAFUCILE:

Se pria ch'abbia il mezzo la notte toccato Alcuno qui giunga, per esso morrà.

MADDALENA:

È buia la notte, il ciel troppo irato, 
Nessun a quest'ora di qui passerà.

GILDA:

Oh qual tentazione!... morir per

l'ingrato!...

Morire!... e mio padre!... Oh cielo pietà!

(battono le undici e mezzo)

SPARAFUCILE:

Ancor c'è mezz'ora...

MADDALENA: (piangendo)

Attendi, fratello...

GILDA:

Che! piange tal donna!.. N'è a lui darò aita!..

Ah, s'egli al mio amore divenne rubello, io vo'per la sua gettar la mia vita...

(scoppio di fulmine, lampo, e tuono; colpi di battente Gilda batte all porta)

MADDALENA:

Si picchia?

SPARAFUCILE:

Fu il vento...

(Gilda batte ancora)

MADDALENA:

Si picchia, ti dico.

SPARAFUCILE:

È strano!.. Chi è?

GILDA:

Pietà d'un mendico;

asil per la notte a lui concedete.

MADDALENA:

Fia lunga tal notte!

SPARAFUCILE: (va a cercare nel credenzone)

Alquanto attendete.

MADDALENA:

$\mathrm{Su}$, spicciati. presto, fa l'opra compita anelo una vita con altra salvar.

\section{SPARAFUCILE:}

Ebbene... son pronto, quell'uscio dischiudi; più ch'altro gli scudi mi preme salvar.

\section{GILDA:}

$\mathrm{Ah}$ ! presso alla morte, sì giovine, sono! Oh ciel, per gl'empi ti chieggo perdono! Perdona tu, o padre, questa infelice! ... Sia l'uomo felice - ch'or vado a salvar.

\section{MADDALENA:}

Su spicciati, presto fa l'opra compita Anelo una vita - con l'altra salvar.

\section{SPARAFUCILE:}

Bene.. son pronto quell'uscio dischiudi; più ch'altro gli scudi mi preme salvar;

(fulmine, lampo, e tuono Gilda picchia di nuovo. Sparafucile va a postarsi con un pugnale dietro la porta; Maddalena apre, poi corre a chiudere la grande arcata di fronte, mentre entra Gilda, dietro a cui Sparafucile chiude la porta, e tutto resta sepolto nel silenzio e nel bujo)

\section{Atto Terzo - Scena VII}

Rigoletto solo si avanza dal fondo della scena chiuso nel suo mantello. La violenza del temporale è diminuita, nè più si vede e sente che qualche lampo e tuono

\section{Rigoletto}

\section{RIGOLETTO:}

Della vendetta alfin giunge l'istante! da trenta dì l'aspetto di vivo sangue a lagrime piangendo, sotto la larva del buffon... (esaminando la casa) Quest'uscio è chiuso!.. Ah, non è tempo ancor!.. S'attenda. 
Qual notte di mistero! una tempesta in cielo!.. in terra un omicidio!..

Oh come in vero qui grande mi sento!.. (L'orologio suona mezzanotte)

Mezza notte!..

(batte alla porta)

\section{Atto Terzo - Scena VIII}

Detto e Sparafucile dalla casa

SPARAFUCILE:

Chi è là?

RIGOLETTO:

Son io...

\section{SPARAFUCILE:}

Sostate.

(rientra e torna trascinando un sacco) è qua spento il vostr'uomo!..

RIGOLETTO:

Oh gioja!.. Un lume!..

SPARAFUCILE:

Un lume?.. No, il danaro.

Lesti, all'onda il gettiam...

RIGOLETTO: (gli dà una borsa)

No... basto io solo.

SPARAFUCILE:

Come vi piace... Qui men atto è il sito... più avanti è più profondo il gorgo... Presto, che alcun non vi sorprenda... Buona notte. (rientra in casa)

\section{Atto Terzo - Scena IX}

Rigoletto, poi il Duca a tempo

RIGOLETTO:

Egli è là!.. morto!.. oh sì!.. vorrei vederlo! ma che importa!.. è ben desso!.. Ecco i suoi sproni!..
Ora mi guarda, o mondo!..

Quest'è un buffone, ed un potente è questo! Ei sta sotto i miei piedi!.. è desso! oh gioja!..

è giunta alfine la tua vendetta, o duolo!..

Sia l'onda a lui sepolcro, un sacco il suo lenzuolo!.. All'onda! all'onda!

(fa per trascinare il sacco verso la sponda, quando è sorpreso dalla lontana voce del Duca, che nel fondo attraversa la scena)

\section{RIGOLETTO:}

Qual voce!.. illusion notturna è questa!. (traselando)No, no!..egli è desso!...Maledizione!

(verso la casa)

Olà... dimon bandito?..

Chi è mai, chi è qui in sua vece?..

(taglia il sacco)

Io tremo... è umano corpo!..

(lampeggia)

\section{Atto Terzo - Scena ULTIMA \\ Rigoletto e Gilda}

Mia figlia!.. Dio!.. mia figlia!..

Ah, no!.. è impossibil!.. per Verona è in via!..

Fu vision!.. è dessa!..

(inginocchiandosi)

Oh mia Gilda!.. fanciulla... a me rispondi!..

l'assassino mi svela... Olà?

(picchia disperatamente alla porta)

Nessuno!.. nessun!.. Mia figlia?.. mia

Gilda?.. oh mia figlia?.

GILDA:

Chi mi chiama?

RIGOLETTO:

Ella parla!.. si move!.. è viva!.. oh Dio! $\mathrm{Ah}$, mio ben solo in terra... mi guarda, mi conosci...

GILDA:

Ah... padre mio!.. 
RIGOLETTO:

Qual mistero!.. che fu!.. sei tu ferita?..

dimmi...

GILDA:

L'acciar...

(indicando il core)

qui... qui mi piagò..

RIGOLETTO:

Chi t'ha colpita?.

GILDA:

V'ho l'ingannato... colpevole fui...

l'amai troppo... ora muojo per lui!..

RIGOLETTO: (da sè)

(Dio tremendo! ella stessa fu côlta dallo stral di mia giusta vendetta!)

(a Gilda)

Angiol caro, mi guarda, m'ascolta...

parla, parlami, figlia diletta!

GILDA:

Ah, ch'io taccia!.. a me... a lui perdonate!.. benedite... alla figlia... o mio padre..

lassù... in cielo, vicina alla madre...

in eterno per voi ... pregherò.

RIGOLETTO:

Non morir... mio tesoro, pietade... se t'involi qui sol rimarrei..

non morire, o qui teco morrò!..

GILDA:

Non più... A lui... perdonate...

mio padre... Ad... dio!

(Muore)

RIGOLETTO:

Gilda! mia Gilda! è morta!.

Ah! la maledizione!!

(Strappandosi i capelli cade sul cadavere della figlia)

\section{FINE}


ANEXO B - Anexo relativo à atividade número 10 da unidade de aprendizagem "La donna è mobile"

1) "mulier (res est) semper varia et mutabilis" (Virgílio, tradução da Eneida, 1. IV, versos 569-70)

2) "Femmina, cosa mobile per natura." (Petrarca, In vita de Madonna Laura, soneto CXXXI) e (Tasso, Aminta, a. I. c. II)

3) "Volubil sempre come foglia al vento" (Boccaccio, Filostrato, p. VIII)

4) "Quanto è meschin colui che cangia voglia

Per donna, o mai per lei s'allegra o dole!

E qual per lei di libertà si spoglia,

O crede a' suoi sembianteo a sue parole!

Che sempre è più leggier ch'al vento foglia,

E mille volte il dì vuole e disvuole:

Segue chi fugge, a chi la vuol s'asconde;

E vanne e vien, come alla riva l'onde." (Angelo Poliziano, Stanze, L. I, 14 - releitura de

Terêncio, Eunuco, a. IV, c. VIII)

5) "Femmina é cosa garrula e fallace.

Vuole e disvuole: è folle uomo che sen fida." (Tasso)

6) "Nunca ponha ninguém a esperança

Em peito feminil, que de natura

Somente em ser mudável tem firmeza." (Camões, Lusíadas, c. IX, est. 46)

7) "Mas se lhe era costume o ser traidora,

Fez muito bem, obrou como quem era;

Que não fora mulher, se assim não fora." (J. Xavier de Matos)

8) "Triste quem ama, cego quem se fia

De feminina voz na vã promessa." (Bocace)

9) "Folle chi crede

Trovar fermeza

Nella crudezza

D'una beltá.

Or da se scaccia,

Or a se chiama,

Altro non brama

Ch’el variar." (Cláudio Manuel da Costa)

10) "Quem se fia de amor, quem se assegura

$\mathrm{Na}$ fantástica fé de uma beleza,

Mostra bem que não sabe o que é firmeza,

Que protesta de amante a formosura. 
Anexa a qualidade de perjura

Ao brilhante esplendor da gentileza,

Mudável é por lei da natureza

A que por lei de amor é menos dura." (Cláudio Manuel da Costa)

11) "(...) efeito foi da natureza

Mais mudável em peito feminil." (Antônio de Sousa Macedo)

12) ¿En qué mujer habrá firmeza alguna?

¿Quien tendrá confianza?

Si quien dijo mujer, dijo mudança?" (Lope de Veja)

13) "(...) a mudança

Em peitos feminis é sempre certa." (Jerônimo Corte Real)

14) "Souvent femme varie,

Bien fol est qui s'y fie

Une femme souvent

N'est qu'une plume au vent." (Victor Hugo, Le Roi s'amuse, IV, 2)

15) "La donna è mobile

Qual piuma al vento,

Muta d'accento

E di pensier..." (Francesco Maria Piave) 

ANEXO C - Anexo relativo à primeira atividade sobre a unidade de aprendizagem "Contexto
social-histórico"

\section{Lettere di Verdi a Piave:}

Busseto, 28 aprile 1850

(...)

Oh Le Roi s'amuse è il più gran sogetto e forse il più gran dramma dei tempi moderni. Tribolet è creazione degna di Shakespeare!! Altro che Ernani!! è sogetto che non può mancare. Tu sai che 6 anni fa quando Mocenigo mi suggerì Ernani, io esclamai: «sì, per Dio... ciò non sbaglia». Ora riandando diversi sogetti quando mi passò per la mente Le Roi fu come un lampo, un'ispirazione e dissi l'istessa cosa... «sì, per Dio ciò non sbaglia». Ebbene, addunque, interessa la Presidenza, metti sottosopra Venezia e fai che la Censura permetta questo sogetto. (...)

Cremona, 3 giugno 1850

Ricevo la tua del 14 Maggio. Finalmente!...

Non avere ostacolo né per la divisione della scena: né per il sacco. Stai pure attaccato al francese e non sbaglierai.

In quanto al titolo quando non si possa tenere Roi s'amuse che sarebbe bello... il titolo deve essere necessariamente La Maledizione di Vallier, ossia per esser più corto La Maledizione. Tutto il sogetto è in quella maledizione che diventa anche morale. Un infelice padre che piange l'onore tolto alla sua figlia, deriso da un buffone di corte che il padre maledice, e questa maledizione coglie in una maniera spaventosa il buffone, mi sembra morale e grande al sommo grande. Bada che La Vallier non deve comparire (come nel francese) che due volte e dire pochissime parole enfatiche profetiche.

Ti ripeto che tutto il sogetto stà in quella maledizione. Non ho tempo dirti altro. Vieni a Busseto e combineremo tutto. Presenta pure alla Presidenza, e Polizia il sogetto. Fà presto ma presto assai. Vieni qui che forse avrò a farti fare un altro lavoro, ma bisogna estrema sollecitudine e segretezza. (...)

\section{Lettera di Piave a Marzari:}

Busseto 15 Agosto 1850

Ricevo in questo punto la favorita sua 10 andante $\mathrm{N}^{\circ} 433$, e sento con maraviglia non poca, come l'ammissione del nuovo mio libretto per Verdi, tratto dal Roi $S$ 'amuse di Vittore Hugo possa trovare qualche difficoltà. La ringrazio peraltro della buona disposizione per parte sua, e prendo coraggio a farle qualche osservazione in proposito, ch'ella si compiacerà far gradire alli altri signori suoi colleghi nonché al Sigr Conte Podestà ed alla I.R. Direzione dell'Ordine Pubblico. La crudeltà dell'azione non è senza esempio, poiché Ernani, Foscari, Lorenzino, Macbet ecc. ec. lo sono forse più. Il Re Francesco non vi è che storicamente dipinto, e la sua visita a Bianca è quasi simile né più né meno a quella di Carlo $\mathrm{V}$ ad Elvira. 
Quanto poi al totale dell'azione, tanto a me che a Verdi ed a' Lei apparirà moralissima, quando si vedano gli spaventosi effetti della maledizione da SaintVallier scagliata su Triboletto, il quale si permette insultare un'infelice padre che viene a cercare riparazione al macchiato onor di sua figlia ed all'onta del sangue suo. Più morale certo di Ernani, di Foscari ec. ec.

(...)

\section{Lettere di Verdi a Marzari:}

Busseto, 24 agosto 1850

Ho sollecitato io stesso Piave a ritornare in Venezia a solo fine di recarle personalmente questa lettera, dirle distesamente quanto io non posso che accennare in iscritto. Il dubbio che Le Roi s'amuse non si permetta mi mette in grave imbarazzo. Fui assicurato da Piave* che non eravi ostacolo per quel sogetto, ed io, fidando nella sua parola, mi posi a studiarlo, a meditarlo profondamente, e l'idea, la tinta musicale erano nella mia mente trovate. Posso dire che per me il principale lavoro era fatto. Se ora fossi costretto appigliarmi ad altro sogetto, non mi resterebbe più tempo di fare tale studio, e non potrei scrivere un'opera di cui la mia coscienza fosse contenta.

$(\ldots)$

Busseto, li 5 dicembre 1850

Sig. Presidente Marzari - Venezia

La lettera arrivata col decreto che proibisce assolutamente La Maledizione, mi è riuscita inaspettata al punto da perderne la testa. In questo, Piave ne ha un gran torto: tutto il torto! Egli mi assicurava in più lettere, scrittemi fin dal mese di Maggio, di averne ottenuta l'approvazione. Dietro questo, io musicai una buona parte del dramma e mi occupava colla massima assiduità onde terminarlo all'epoca prefissa. Il decreto che lo rifiuta mi mette alla disperazione, perché ora è troppo tardi per scegliere altro libretto che mi sarebbe impossibile, affatto impossibile di musicare per questo Inverno. Era la terza volta che avevo l'onore di scrivere per Venezia e la Nob. Presidenza sa con quanta esattezza abbia sempre adempito a' miei doveri. Ella sa che in un letto quasi morente diedi parola di finire l'Attila, e lo finii. Ora, sull'onor mio ripeto che mi è impossibile scrivere un nuovo libretto, quand'anche volessi occuparmi al punto da perderne la salute.

(...)

\section{Lettera di Marzari a Verdi:}

Venezia, 23 dicembre 1850.

Al Sig. Maestro Giuseppe Verdi,

Mentre la sua lettera del 14 corrente mi piombava in grave imbarazzo, non potevo non riconoscere l'inopponibilità di alcune delle sue riflessioni. Le feci dunque tema di nuove interpellazioni all'Autorità d'Ordine Pubblico ed ho finalmente convenuto collo stesso Sig. Direttore Centrale d'Ordine Pubblico che, fermo il pensiero di variare, com'ella stessa acconsente, luogo ed epoca dell'azione, verranno conservate al libretto stesso le tinte ed i caratteri originali ch'ella desidera. Il personaggio sostituito a Francesco, che potrà essere com'ella conviene o un 
Pier Luigi Farnese o forse meglio un Medici o un duca di Borgogna o di Normandia, potrà essere libertino e padrone assoluto del suo stato. Il buffone potrà essere deforme, com'ella desidera. Non si farà ostacolo al sacco, e solamente converrà dare al rapimento della figlia del buffone un colore che conservi i riguardi dovuti alla scena.

$(\ldots)$ 
ANEXO D - Glossário utilizado no curso "Rigoletto: per gli amanti della lingua e della cultura italiana"

\section{Breve glossario dei principali termini operistici con gli esempi in Rigoletto}

à|ria

s.f.

TS mus., composizione melodica vocale o strumentale, a schema strofico, che può stare a sé o fare parte di un melodramma, di una cantata, ecc: Cortigiani, vil razza dannata, La donna è mobile, ecc.

àt|to

s.m.

consuetudinale divisione dell'opera teatrale (opere, drammi e balletti). Di solito il numero degli atti varia da 1 a 5 .

bal|là|ta

s.f.

componimento musicale vocale o strumentale, a carattere sentimentale, tipico del periodo romantico: Questa o quella per me pari sono

ba|rì|to|no

s.m.,agg.

nel canto, voce maschile intermedia tra quella del tenore e quella del basso | il cantante che canta in tale tonalità: Rigoletto, Il Conte di Monterone, Marullo

bàs|so

s.m.

la voce maschile di registro più grave | cantante che ha tale voce: Sparafucile, Il Conte di Ceprano

ca|ba|lét|ta

s.f.

breve aria d'opera vivace e orecchiabile, di solito collocata alla fine di un assolo o di un duetto nel melodramma italiano del primo Ottocento: alla fine del secondo atto

ca|va|tì|na

s.f.

in opere e oratori, breve arioso a carattere lirico e struttura semplice, che conclude un recitativo ed è generalmente usato per caratterizzare personaggi | nella musica strumentale, brano lirico senza sviluppo: Parmi veder le lacrime

co|lo|ra|tù|ra

s.f.

ornamentazione virtuosistica della melodia, scritta dal compositore stesso o affidata all'improvvisazione del cantante: la coloratura del soprano in Caro nome 
co|ló|re

s.m.

in acustica, timbro di un suono | qualità o timbro di una vocale: il colore del preludio è scuro.

con|cer|tà|to

s.m.

di composizione in cui si alternano parti vocali e parti strumentali: Atto I, scena $\mathrm{V}$

con|tràl|to

s.m.

voce femminile o voce bianca del registro più grave | la cantante o il cantore che ne sono dotati: Maddalena

cò|ro

s.m.

cantanti raggruppati secondo i vari registri vocali: Atto I, scena IX

mez|zo|so|prà|no

s.m.

nel canto, voce femminile intermedia tra il soprano e il contralto | la cantante o il cantore che ne sono dotati: Giovanna

mi|nu|ét|to

s.m.

tra il Settecento e l'inizio dell'Ottocento, brano strumentale inserito come terzo tempo nelle sinfonie, nelle sonate, ecc.: Atto I, scena II

pre|lù|dio

s.m.

brano strumentale che introduce una composizione musicale, un'opera $\mid$ in età romantica, brano autonomo di forma libera, caratterizzato da intenso lirismo

pe|ri|gor|di|no

s.m.

danza di origine francese in movimento molto vivace e in tempo di 6/8, apparsa nel XVIII secolo: danza della festa nel palazzo ducale - Atto I

quar|tét|to

s.m.

composizione musicale per quattro strumenti o per quattro voci: Bella Figlia dell'amore | il complesso che esegue tale composizione

re|ci|ta|ti|vo

agg., s.m.

stile di canto, caratteristico dell'opera lirica, tendente a riprodurre, attraverso una recitazione intonata, la naturalezza e flessibilità della lingua parlata, caratterizzato da un ritmo libero e irregolare, modellato su quello verbale, e dalla mancanza di un'autonoma 
struttura formale, sostituita da un libero modellarsi della musica sui nuclei sintattici del testo; anche agg.: stile, modo $r$. | brano eseguito in tale stile: Atto III, scena IX

ro|màn|za

s.f.

composizione per canto e accompagnamento strumentale caratterizzata da un andamento melodioso e patetico che, nata in Francia alla fine del Settecento, conobbe nell'Ottocento grande fortuna negli ambienti borghesi europei | nel melodramma, aria, spec. di intonazione patetica: Caro nome

scè|na

s.f.

in un'opera teatrale, cinematografica o televisiva, unità narrativa minima costituita da un'azione dotata di autonomia e coerenza con la storia narrata: Ella mi fu rapita!... Parmi veder le lagrime (scena ed aria del Duca)

so|prà|no

s.m.

voce femminile o voce bianca dal registro più acuto | la cantante o il cantore che ne sono dotati: Gilda

te|nó|re

s.m.

nel canto, la voce maschile con il registro più alto | cantante che è dotato di tale voce: $I l$ Duca di Mantova

\section{Referências}

CORTE, Andrea della. Dizionario di musica. 3 ed. Torino : G. B. Paravia, 1925.

DE MAURO, T. Dicionário on-line da língua italiana. Disponível em $<$ www.demauroparavia.it>. Acesso em jul 2008.

WIKIPÉDIA. Enciclopédia virtual. Disponível em: < http://pt.wikipedia.org/wiki/Teatro>. Acesso em jul 2008. 